UNIVERSIDADE DE SÃO PAULO

INSTITUTO DE GEOCIÊNCIAS

\title{
TECTÔNICA RÚPTIL APLICADA AO ESTUDO DE AQÜÍFERO EM ROCHAS CRISTALINAS FRATURADAS NA REGIÃO DE COTIA, SP
}

Fernando Machado Alves

Orientador: Prof. Dr. Claudio Riccomini

\section{DISSERTAÇÃO DE MESTRADO}

Programa de Pós-Graduação em Geoquímica e Geotectônica

São Paulo

2008 
UNIVERSIDADE DE SÃO PAULO

INSTITUTO DE GEOCIÊNCIAS

\section{TECTÔNICA RÚPTIL APLICADA AO ESTUDO DE AQÜÍFERO EM ROCHAS CRISTALINAS FRATURADAS NA REGIÃO DE COTIA, SP}

Fernando Machado Alves

Orientador: Prof. Dr. Claudio Riccomini

\section{DISSERTAÇÃO DE MESTRADO}

Programa de Pós-Graduação em Geoquímica e Geotectônica

SÃO PAULO

2008 
Dedico este trabalho a Silene Machado Alves (in memorian), minha querida e saudosa mãe, que acredito ser a grande responsável por minha vontade de aprender sempre mais, com pensamento aberto para o saber e a educação, e ao grande apetite por leitura, quesito essencial a um cidadão e para a formação intelectual. 


\section{AGRADECIMENTOS}

Agradeço a Deus, por toda a sua obra, que com certeza levou mais de 7 dias, e provavelmente menos de 5 bilhões de anos para ser realizada, obra de tamanha complexidade geológica que nos proporciona tão incríveis desafios de reconstituição e interpretação.

Ao professor Claudio Riccomini, pela orientação, amizade e confiança neste "colunista semanal".

Ao Instituto de Geociências da Universidade de São Paulo e a ERM Brasil pela viabilização deste projeto e pela formação acadêmica e profissional, respectivamente.

A meu pai Antônio Carlos, minha irmã Francine e minha família, pelo apoio, compreensão, estímulo ou exemplo.

Agradeço aos amigos geólogos, que muita ajuda e as vezes co-orientação me ofereceram; dentre outros não posso deixar de citar Samar, Guano, Feith, Vermelho, Birelli, Bisteca, Genérico, Transformer, Passivo, Polegar, Meladoh, Urtiga, Xubaca, Lalas e Prof. Dr. Reginaldo Bertolo...

Aos amigos e colegas de ERM, Alaine, Berguedof, Boliva, Cris Spilborghs, Donizete, Enrico, Fabiana Cagnon, Fernandinho, Flávio, Guma, Juliana, Laura, Maurício, Ricardo Camargo, Simone, Samuel, Sasha, Sander e Susanne que me ajudaram ou de alguma forma contribuíram para o presente trabalho. Agradeço também os que não atrapalharam.

Enfim cheguei a ser mestre, seguindo alguns outros que me inspiraram. Neste sentido, agradeço ao Mestre Yoda, Mestre Obiwan Kenobi, Mestre dos Magos, Mestre Li Mon Pae, Mestre Hatory Hanzo e ao Chuck Norris, exemplo de força e determinação. 


\section{SUMÁRIO}

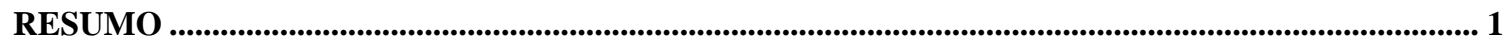

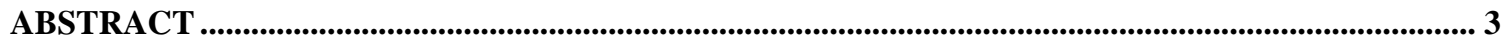

1 INTRODUÇÃ

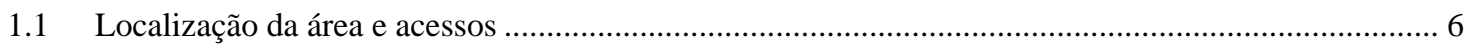

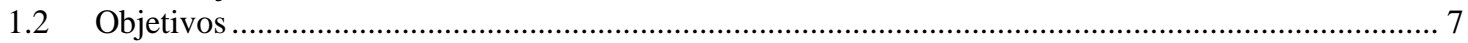

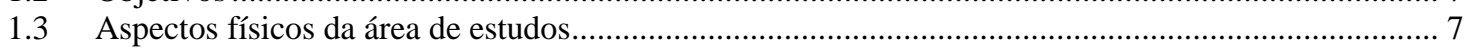

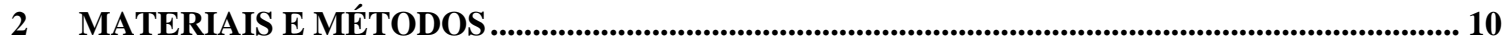

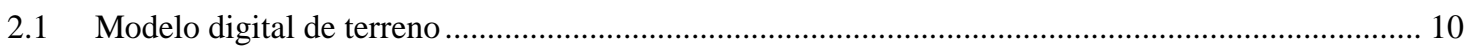

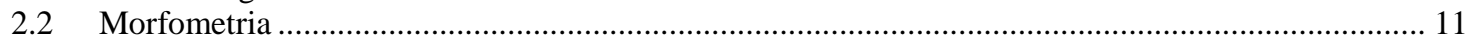

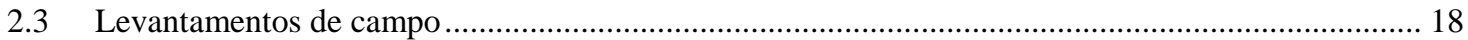

2.4 Perfuração e instalação dos poços de monitoramento do aqüífero fraturado ........................................ 25

2.5 Perfilagem acústica das perfurações (técnica BHTV) ....................................................................... 29

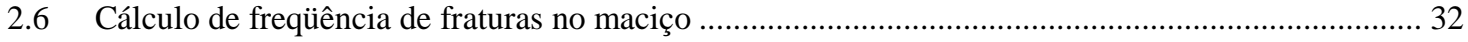

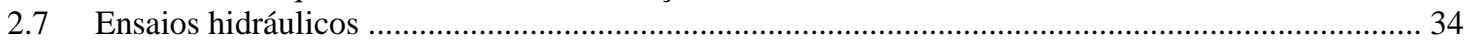

3 HIDROGEOLOGIA DE AQÜÍFEROS EM MEIO FRATURADO …............................................ 39

3.1 Importância e aplicação dos estudos em aqüíferos fraturados ............................................................ 40

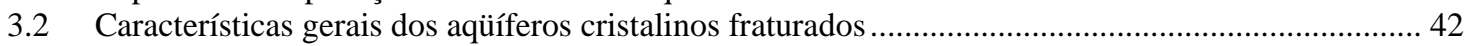

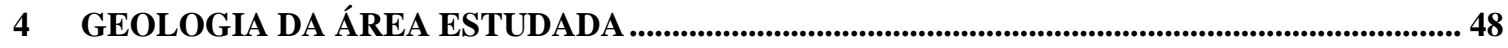

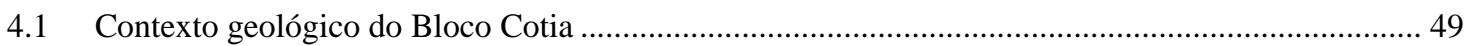

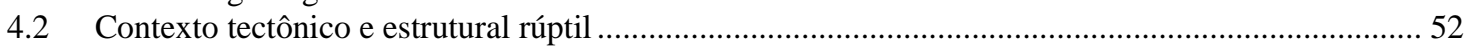

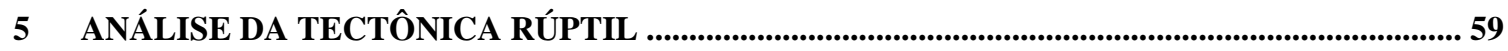

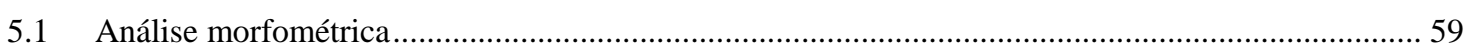

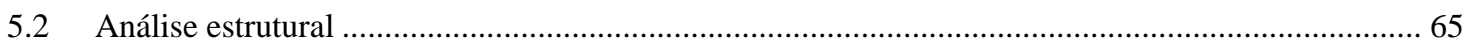

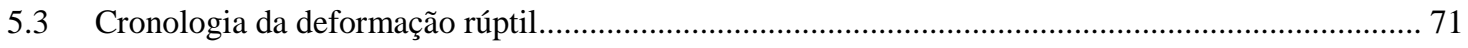

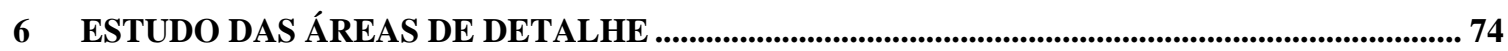

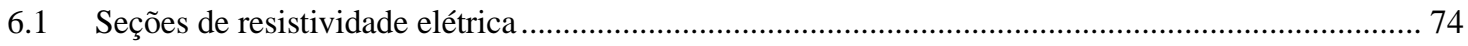

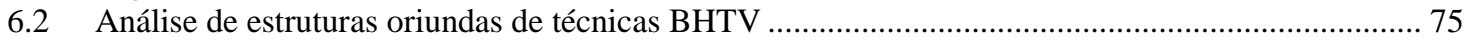

6.3 Densidade de fraturamento ...................................................................................................... 80

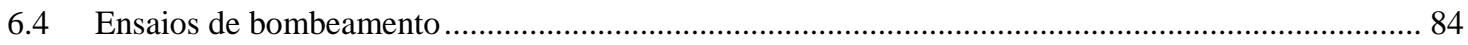

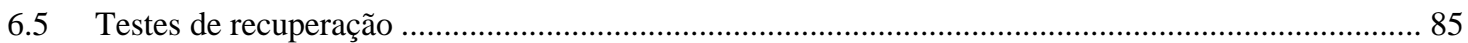

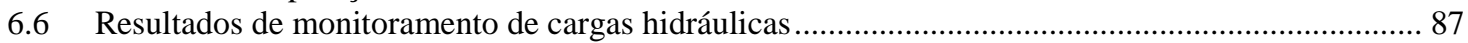

7 TECTÔNICA RÚPTIL APLICADA À HIDROGEOLOGIA EM AQÜÍFERO CRISTALINO

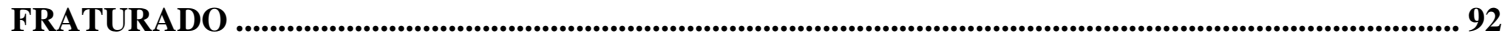

7.1 Análise da tectônica rúptil da área de semi-detalhe ...................................................................... 92

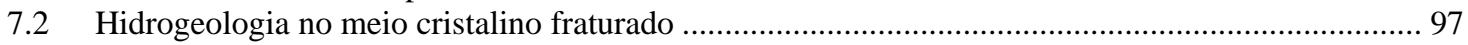

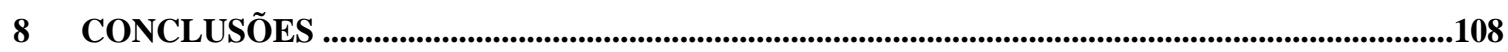

9 REFERÊNCIAS BIBLIOGRÁFICAS....................................................................................11

ANEXO I - FIGURAS

ANEXO II - TABELAS

ANEXO III - ENSAIOS HIDRÁULICOS 


\section{RESUMO}

O estudo da hidrogeologia em aqüífero cristalino fraturado apresenta como maior desafio a imprevisibilidade do meio, uma vez que o fluxo ocorre exclusivamente pelas fraturas. Neste sentido informações de atitude, abertura e conectividade de fraturas tornam-se essenciais no entendimento do fluxo da água subterrânea. O presente trabalho busca aplicar o conhecimento da tectônica rúptil para caracterizar o meio fraturado, com intuito de auxiliar o estudo hidrogeológico do aqüífero.

A área de estudo está localizada na porção leste do Município de Cotia, SP, no contexto do Complexo Embu, de idade proterozóica, na porção central da Faixa Ribeira. Ocorrem predominantemente rochas granitóides, com permeabilidade primária desprezível, rochas cataclásticas relacionadas às grandes zonas de cisalhamento de Taxaquara e Caucaia do Alto, metassedimentos e coberturas aluviais cenozóicas, estas ao longo das principais drenagens. Os principais eventos tectônicos de caráter rúptil da região estiveram relacionados à reativação mesozóico-cenozóica, inicialmente com a ruptura continental e abertura do Oceano Atlântico Sul e, posteriormente, a formação do Rift Continental do Sudeste do Brasil (RCSB), e seus principais eventos de deformação.

Os estudos foram desenvolvidos em duas escalas de trabalho. A primeira de semi-detalhe, em 1:50.000, e a segunda de detalhe, em 1:5.000, esta última em duas porções distintas dentro da área de semi-detalhe. Os resultados obtidos em escala de semi-detalhe, a partir da análise da tectônica rúptil (morfometria, fotogeologia e levantamentos de campo), serviram para direcionar as investigações em escala de detalhe, onde foram usados dados provenientes de sondagens, métodos BHTV (Bore Hole Television), levantamento de perfis de eletrorresistividade e dados hidrogeológicos de poços de monitoramento instalados no aqüífero em meio fraturado.

Os estudos de escala de semi-detalhe permitiram delinear lineamentos de direções N-S, E-W, NE-SW e NW-SE, originados pelas diversas fases de 
deformação rúptil. Esses dados de lineamentos foram correlacionados com dados de atitude de falhas e juntas medidas em afloramento, e, posteriormente, associados às diferentes fases de deformação descritas para o RCSB. Foram definidas seis famílias de juntas: a) família NNW-SSE, com mergulho alto para $\mathrm{NE}$ ); b) família NE-SW com mergulho sub-vertical; c) família E-W com mergulho alto para NW); d) família WNW-ESE com mergulho alto para NE); e) família NESW com mergulho médio para NW; e f) família NE-SW com mergulho médio para SE.

Os resultados dos estudos desenvolvidos em escala de semi-detalhe, somados aos condicionantes geológicos e geomorfológicos das áreas selecionadas para estudos de detalhe, orientaram a instalação de poços de monitoramento verticais e inclinados nessas últimas. Foram instalados 11 poços na área de detalhe $A$ e quatro poços na área de detalhe $B$. Os poços foram perfilados por televisionamento acústico e as fraturas identificadas nesses poços foram separadas por famílias e subfamílias: Família 1 (sub-horizontal), Família 2A ( $\mathrm{N}-\mathrm{S}$ com mergulho médio para $\mathrm{W}$ ) e 2B (N-S com mergulho alto para $\mathrm{E}$ ), Família 3A (NE-SW com mergulho médio para NW) e 3B (NE-SW com mergulho médio para SE) e Família 4 (WNW-ESE sub-vertical).

$\mathrm{Na}$ maioria dos poços foram realizados ensaios hidráulicos para determinação da condutividade hidráulica $(K)$, que variou de $1,55 \times 10^{-8}$ a $2 \times 10^{-5}$ $\mathrm{cm} / \mathrm{s}$, com média de $2,98 \times 10^{-6}$ e desvio padrão de $5,60 \times 10^{-6} \mathrm{~cm} / \mathrm{s}$. Ensaios de bombeamento indicaram fluxo de água subterrânea através das estruturas N-S, com boa conexão com as estruturas NE-SW. A abertura média das fraturas foi de $1,13 \times 10^{-3} \mathrm{~cm}$, calculada com base nos valores de condutividade hidráulica correlacionados aos dados estruturais.

A partir dos dados hidrogeológicos e estruturais foi proposto um método para se estimar a transmissividade e condutividade hidráulica de um poço instalado no aqüífero fraturado. 


\section{ABSTRACT}

The main challenge in a hydrogeological study of a fractured-bedrock aquifer is the unpredictability of media, because the ground-water flows only through the fractures. Informations about strike, dip, opening and connectivity among fractures become essential in order to understand the ground-water flow. This work is an application of the concepts of the brittle tectonics to characterize a fractured media in order to help the hydrogeological study of a fractured-bedrock aquifer.

The study area is located at the eastern part of the City of Cotia, State of São Paulo, Southeastern Brazil, in the context of the Proterozoic Embu Complex, in the central part of Ribeira Belt. This area encompass predominantly granitoid rocks (with negligible primary permeability), cataclastic rocks related to the Taxaquara and Caucaia do Alto shear zones, and metasedimentary rocks. Quaternary alluvial deposits occur along the main drainages. The main brittle tectonic events in the region are related to the Mesozoic-Cenozoic reactivation, associated with the continental break-up, the opening of the South Atlantic Ocean, and the formation and deformation of the basins of the Continental Rift of the Southeastern Brazil (CRSB).

The study was carried out in two working scales. First in a semi-detail scale, at $1: 50,000$, of a large area, were brittle tectonic analysis (morphometry, photogeology and field survey in outcrops) was performed. The achieved results were used to select two small areas, within the semi-detail area, for a detailed investigation, on scale of 1:5,000, in which data from rock-boring, BHTV (Bore Hole Television), eletroresistivity and hydrogeology from bedrock monitoring wells were obtained.

At a semi-detail scale it was possible to delineate lineaments of $\mathrm{N}-\mathrm{S}, \mathrm{E}-\mathrm{W}$, NE-SW and NW-SE-trending directions, probably originated during several brittle deformational events. Data from lineaments were first correlated with data of fault and joint measured in outcrops and latterly associated with different deformation phases described in CRSB. Six joint families were defined: a) steeply northeastward dipping NNW-SSE-trending family; b) sub-vertically dipping NE-SW- 
trending family; c) steeply northwestward dipping E-W-trending family; d) steeply northeastward dipping WNW-ESE-trending family); e) NE-SW-trending family with moderate dipping towards the NW; and f) NE-SW-trending family with moderate dipping towards the SE.

Results of studies in the semi-detail investigation area allowed the selection of sites for drilling of 11 wells in detail area A and 4 wells in the detail area B. All the wells were surveyed by acoustic teleview and the identified fractures were classified in four families and two subfamilies: family 1 (sub-horizontal to gently dipping); family $2 \mathrm{~A}$ (N-S-trending with moderate dipping towards the $\mathrm{W}$ ) and $2 \mathrm{~B}(\mathrm{~N}$ S-trending with steep dipping towards the $E$ ); family $3 A$ (NE-SW-trending with moderate dipping towards the NW) and 3B (NE-SW-trending with moderate dipping towards the SE); and family 4 (WNW-ESE-trending with sub-vertical dipping).

Hydraulic conductivity $(\mathrm{K})$ measured in the wells ranged from $1.55 \times 10^{-8}$ to $2 \times 10^{-5} \mathrm{~cm} / \mathrm{s}$, with a mean of $2.98 \times 10^{-6}$ and standard deviation of $5.60 \times 10^{-6} \mathrm{~cm} / \mathrm{s}$. Pumping tests showed the groundwater flow through $\mathrm{N}$-S-trending structures and good connection with NE-SW-trending structures. The average opening of fractures attained $1.13 \times 10^{-3} \mathrm{~cm}$ and was calculated on the basis of the amount of hydraulic conductivity correlated with structural data.

Based on structural and hydrogeological data it was proposed a method for estimating the transmissivity and hydraulic conductivity of a well installed in the fractured-bedrock aquifer. 


\section{INTRODUÇÃO}

O estudo de aqüíferos fraturados apresenta grande importância devido a dois aspectos principais, a prospecção de água subterrânea em meios de baixa porosidade primária (e.g. embasamento cristalino) e a contaminação por atividades antrópicas. A maior parte dos estudos em meios cristalinos fraturados usualmente empregam uma abordagem descritiva das estruturas observadas em uma dada localidade, tendendo a tratar o maciço como um meio poroso, ao invés de se preocupar com a elucidação dos mecanismos geradores das fraturas, que permitem a elaboração de modelos de distribuição das fraturas e anisotropias.

Investigações hidrogeológicas podem se deparar com situações que abrangem características estruturais do meio, como fraturas que atuam como caminhos da água subterrânea em aqüífero de meio fraturado, ou como anisotropias em aqüíferos em meio poroso inconsolidado. Com intuito de desenvolver um método que permita estes estudos, o presente trabalho se propõe a utilizar os conhecimentos da tectônica rúptil para detalhar o padrão de fraturamento de uma área, definir os mecanismos geradores das deformações rúpteis, e elaborar um modelo conceitual da distribuição das estruturas rúpteis com potencial para serem caminhos preferenciais da água subterrânea.

Estudos recentes sobre a tectônica rúptil na região sudeste do Brasil vêm demonstrando a importância da análise integrada de dados estruturais e morfométricos como ferramentas em estudos de tectônica rúptil e neotectônica (e.g. Ferrari 2001, Chiessi 2004, Alves 2005, Hartwig 2006). O presente estudo é uma aplicação da tectônica rúptil ao estudo de aqüífero fraturado em rochas do embasamento cristalino na região de Cotia, SP.

Trabalhos relacionados ao estudo da influência da tectônica na produtividade de poços de abastecimento foram elaborados nos últimos anos. Para as regiões de Campinas (Fernandes 1997), Jundiaí (Neves 2005, Neves \& Morales 2006 e Neves \& Morales 2007) e Bacia Hidrográfica do Médio Tietê (Jesus 2005) foram comparados os dados hidrogeológicos com estruturas 
tectônicas rúpteis e compartimentação geológica. $\mathrm{Na}$ região de Lindóia, a hidrogeologia de aqüífero em meio fraturado foi abordada com base em dados geofísicos, de sensoriamento remoto e geoprocessamento (Madrucci 2004).

No presente trabalho os resultados obtidos em escala de semi-detalhe na análise da tectônica rúptil serviram para direcionar as investigações em escala de detalhe, onde foram usados dados provenientes de perfurações, sondagens, métodos BHTV (Bore Hole Television), levantamento de perfis de eletrorresistividade e dados hidrogeológicos de poços de monitoramento instalados no aqüífero em meio fraturado.

Por fim, os dados obtidos nas duas escalas de investigação foram confrontados para verificar a existência de correlações e a validade da extrapolação de dados regionais para os sítios de investigação de maior detalhe.

\subsection{Localização da área e acessos}

A área de estudo de semi-detalhe está localizada na porção leste do Município de Cotia, Estado de São Paulo, entre as latitudes 7.393.350 e 7.385.400 sul e longitudes 303.990 e 311.280 oeste, zona $23 \mathrm{~K}$.

A partir de São Paulo o principal acesso é feito pela Rodovia Raposo Tavares, que atravessa a área de oeste a leste, entre os quilômetros 25,5 e 32,5.

A área de estudos abrange aproximadamente $58 \mathrm{~km}^{2}$ e se insere no contexto das rochas proterozóicas do Complexo Embú. A localização foi definida com base na presença de dois sítios para o estudo em detalhe, e suas dimensões ajustadas para compatibilizá-las com a resolução dos dados de interferometria de radar do Shuttle Radar Topography Mission (SRTM). Os sítios de estudo em detalhe localizam-se aproximadamente no centro da área, próximos à rodovia Raposo Tavares. As sondagens e poços foram localizados e georreferenciados por levantamento topográfico.

O mapa de localização da área, estradas e sítios de detalhe é apresentado no Anexo I, figura 1. 


\subsection{Objetivos}

O objetivo principal deste trabalho é a caracterização estrutural do maciço rochoso da área definida e o papel das estruturas geológicas no controle das anisotropias do aqüífero em meio fraturado. Toda a área está sobre o embasamento cristalino, onde a ocorrência de água subterrânea é condicionada principalmente pelo material de alteração inconsolidado, e pelas descontinuidades da rocha. Sendo assim, tornaram-se necessárias:

- a caracterização geológico-estrutural, morfoestrutural e tectônica da área, com ênfase nas estruturas rúpteis;

- a caracterização hidrogeológica dos sistemas aqüíferos com base nos dados de poços profundos;

- a correlação de dados estruturais obtidos em escala de semi-detalhe e escala de detalhe;

- a integração entre dados geológico-estruturais e hidrogeológicos.

\subsection{Aspectos físicos da área de estudos}

\subsubsection{Geomorfologia Regional}

Segundo a divisão geomorfológica para o Estado de São Paulo (Almeida 1964), a região de estudos está inserida no Planalto Atlântico, caracterizado como uma região de terras altas, constituído predominantemente por rochas cristalinas pré-cambrianas, cortadas por intrusivas básicas e alcalinas mesozóico-cenozóicas e recobertas por depósitos das bacias sedimentares de São Paulo e Taubaté.

Para o detalhamento destas unidades, Almeida (1964) propôs uma subdivisão em zonas. Destas, três zonas geomorfológicas do Planalto Atlântico estão contidas nas imediações da área de estudo: a Serrania de São Roque, o Planalto de Ibiúna e o Planalto Paulistano, mais especificamente a região da Morraria do Embu.

A Serrania de São Roque é uma extensa área montanhosa, onde as maiores altitudes são encontradas na Serra do Japi, com cerca de 1200-1250 
metros. Possui composição litológica diversificada, que vai dos metamorfitos de baixo grau do Grupo São Roque até rochas gnáissicas e migmatíticas com intrusões graníticas.

O Planalto de Ibiúna é uma unidade de pequenas dimensões, na qual o relevo é sustentado por rochas graníticas, gnáissicas e metassedimentares. $O$ planalto é formado predominantemente por granitos relacionados com as elevações mais altas. A unidade faz limite com a zona serrana de São Roque, ao norte, através da Serra de Taxaquara.

O Planalto Paulistano apresenta relevo suave na parte central, com colinas e áreas de morros cristalinos com altitude entre 715 e 900 metros, onde predominam micaxistos. O compartimento referente à Morraria do Embu compreende terrenos cristalinos que circundam a Bacia de São Paulo a oeste, sul e leste, com nível topográfico mais elevado e processos de evolução de vertentes mais dinâmicos. Apresenta relevo de morros e uma rede de drenagem muito densa.

\subsubsection{Clima}

O Planalto Paulistano representa uma região de transição climática e diferentes classificações foram propostas conforme o período selecionado para a avaliação climática e a delimitação do período de seca (Aragaki \& Mantovani 1998). A partir dos dados meteorológicos fornecidos pelo Centro Integrado de Informações Agrometereológicas (CIIAGRO) para Ibiúna (figura 5.1) pode-se caracterizar o clima da área de estudo como temperado quente e úmido, do tipo Cfa (Köppen 1948), com temperatura média mensal do mês mais quente acima de $22^{\circ} \mathrm{C}$ e precipitação média do mês mais seco entre $30-60 \mathrm{~mm}$. A precipitação média anual fica em torno de $1280 \mathrm{~mm}$. Os dados climáticos padronizados indicam a existência de uma sazonalidade na região, com uma diminuição na pluviosidade e temperaturas médias entre os meses de abril e agosto, mas sem apresentar déficit hídrico (figura 5.1). Segundo dados da SABESP (1997), a área da bacia do rio Cotia é fortemente afetada por frentes frias e linhas de instabilidade. 
A direção predominante do vento durante todo o ano é SE/SSE, e secundariamente predomina a direção WNW/NW durante o período de maior aquecimento do dia (15 horas local), sendo que as maiores velocidades médias anuais atingem 2,6 m/s (SABESP 1997).

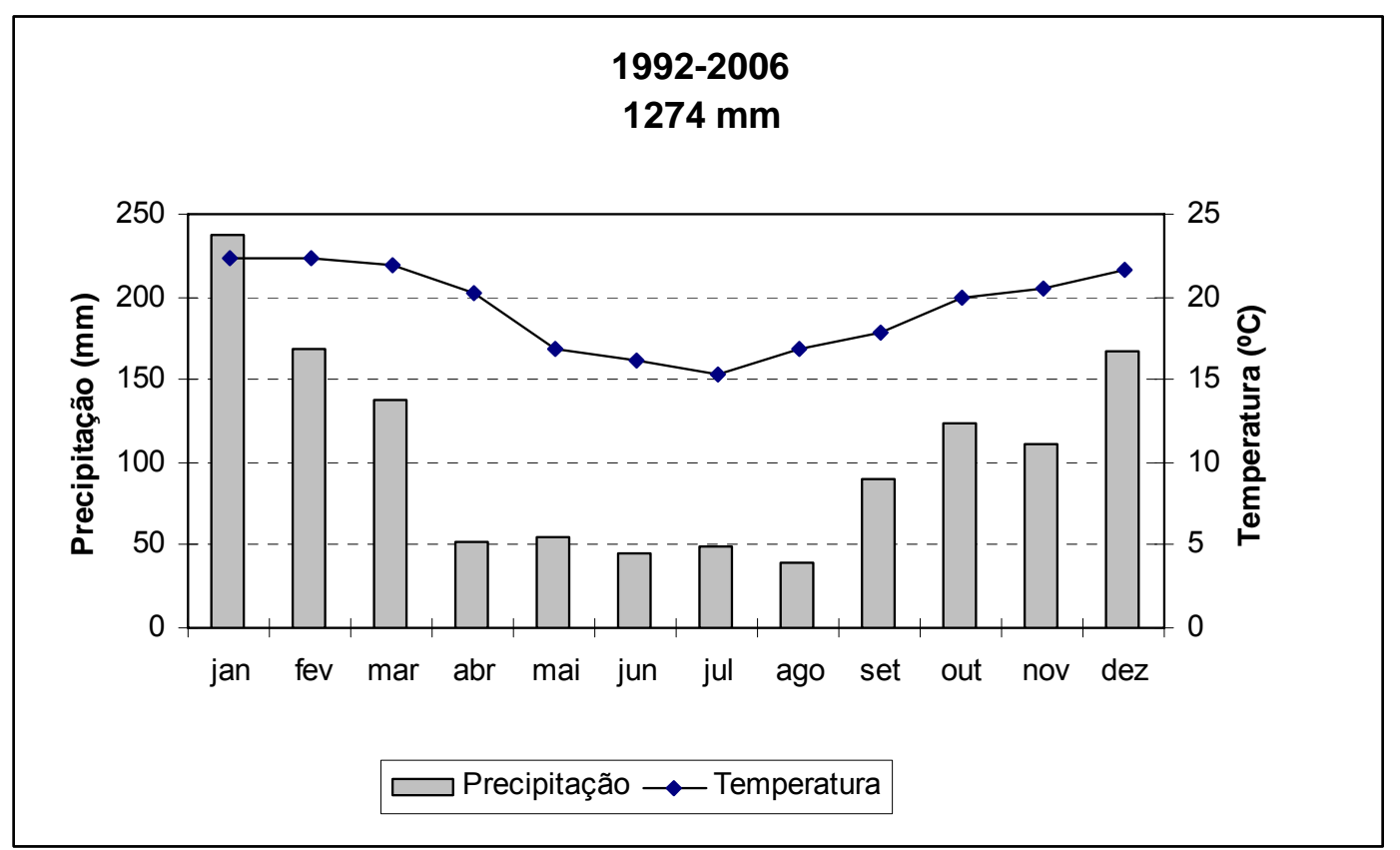

Figura 1.1 - Precipitação média mensal $(\mathrm{mm})$ e temperatura média mensal $\left({ }^{\circ} \mathrm{C}\right)$ no período de 1992-2006 para a região de estudo. Dados meteorológicos coletados no Posto Meteorológico de Ibiúna, SP $\left(47^{\circ} 13^{\prime} \mathrm{W}\right.$ e $23^{\circ} 40^{\prime} \mathrm{S}, 850 \mathrm{~m}$ de altitude) distante cerca de $25 \mathrm{~km}$ da região de estudo (Fonte de dados: CIIAGRO - Instituto Agronômico de Campinas, SP, www.iac.sp.gov.br). 


\section{MATERIAIS E MÉTODOS}

\subsection{Modelo digital de terreno}

O modelo digital de terreno (MDT) pode ser construído a partir da interpolação de pontos cotados ou de curvas de nível, estejam elas em formato raster ou vetor. Desta forma, para a geração do MDT pode-se optar por um método que utiliza curvas de nível vetorizadas a partir de folhas topográficas ou, alternativamente, pelo método de pontos cotados com espaçamento de grade, também conhecido como DEM (Digital Elevation Model) (Grohmann, 2004).

O MDT foi produzido com o uso do programa Arcview (ESRI), empregado para processamento dos dados no formato DEM provenientes de interferometria de radar (SRTM) da National Aeronautics and Space Administration (NASA), com resolução espacial de $90 \mathrm{~m}$, que estão disponíveis no endereço da NASA na rede mundial de computadores (ftp://e0srp01u.ecs.nasa.gov/srtm/version2/). O MDT gerado compreende a área limitada pelas coordenadas UTM 7.377.4207.401.300 N e UTM 296.700-318.600, zona 23K, que extrapola a região de estudos com o intuito de caracterizar anomalias situadas nas extremidades da área de trabalho.

A área de trabalho não apresenta uma dimensão adequada para a resolução de $90 \mathrm{~m}$. Por esta razão decidiu-se empregar técnicas de reamostragem da imagem de resolução $90 \mathrm{~m}$ para promover um aumento de resolução espacial para $30 \mathrm{~m}$, na qual, cada pixel na imagem do MDT equivale a $30 \mathrm{~m}$ no terreno. Para o aumento da resolução foi utilizada a técnica apresentada por Grohmann \& Steiner (2006), com uso da linguagem estatística R (Ihaka \& Gentken 1996, Grunski 2002) e o Global Mapper de uso em GIS. A técnica consiste na atribuição de valores de altitude em uma malha de pontos de resolução 30 metros, e as altitudes dessa malha são provenientes dos vizinhos imediatos ao ponto mediante a aplicação da técnica SDLN (Short Distance-Low Nugget Kriging). 


\section{$2.2 \quad$ Morfometria}

A atividade tectônica em uma dada região pode alterar seus padrões geomorfológicos e gerar anomalias que serão detectáveis por meio da observação de seus principais atributos, a topografia e a sua rede de drenagens. A caracterização dessas anomalias geomorfológicas em regiões afetadas por atividade tectônica torna-se importante em função da abrangência do intervalo de tempo dos registros dessa natureza, quando comparados a outras fontes de informação (figura 2.1).

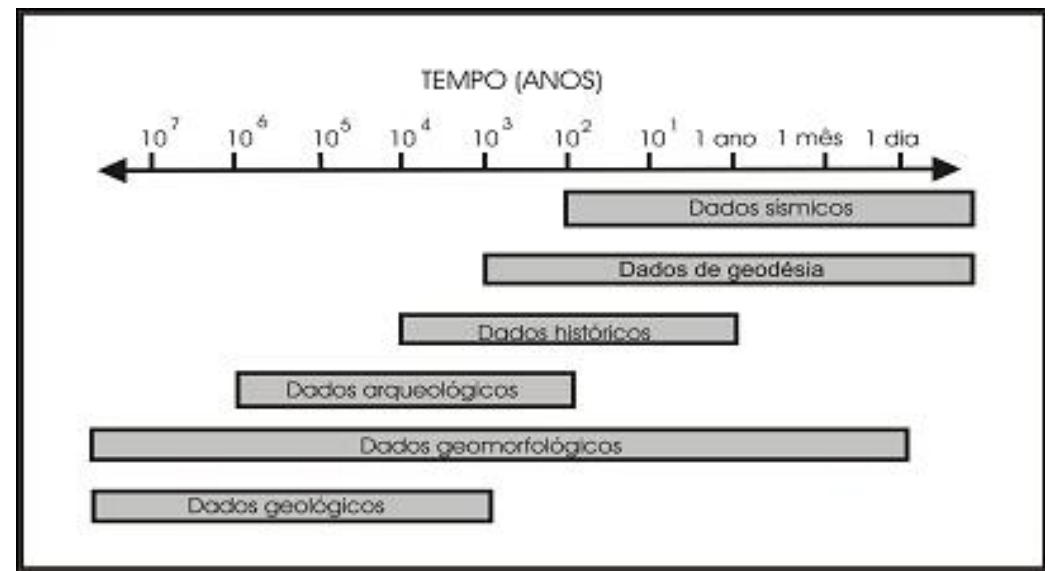

Figura 2.1 - Abrangência temporal das diversas fontes de informações tectônicas. Modificado de Vita-Finzi (1986).

Em estudos recentes, a análise morfométrica mostrou-se como uma importante ferramenta para a identificação de anomalias nos padrões geomorfológicos e, conseqüentemente, dos indicadores de movimentações tectônicas recentes (Rodriguez 1993, Salvador \& Riccomini 1995, Hiruma \& Riccomini 1999, Chiessi 2004, Alves 2005, Hartwig 2006).

No presente trabalho foi empregada a análise morfométrica para avaliar descontinuidades geomorfológicas, com o intuito de inferir feições tectônicas e auxiliar na escolha de áreas para o foco das atividades de campo. A partir do MDT foram criados mapas em escala 1:50.000, correspondentes aos parâmetros morfológicos mais comumente utilizados na análise morfotectônica, ou o estudo 
dos efeitos tectônicos em um determinado relevo, como mapas hipsométrico, de orientação de vertentes, de declividade, de superfícies de base, de rugosidade de relevo, de densidade de drenagens e de densidade de lineamentos, e ainda mapa de lineamentos estruturais a partir de sombreamento de relevo (Liu 1987, Riccomini \& Crósta 1988, Grohmann 2004).

\subsubsection{Mapa hipsométrico}

Após a elaboração do modelo digital de terreno (MDT), as altitudes do MDT foram classificadas com uso do programa Arcview (ESRI), e as diferentes classes cartografadas com uso de cores distintas. No mapa hipsométrico foram definidos 8 classes de altitude.

O uso criterioso deste mapa é de grande valia na classificação geomorfológica de uma determinada área. Esta ferramenta permite, com grande eficiência, a separação de áreas de planícies e acidentadas, assim como observar a posição dos vales e terrenos mais elevados da área. Em termos gerais, esta é a forma mais usual de apresentação do MDT.

\subsubsection{Extração de lineamentos morfoestruturais}

Os lineamentos morfoestruturais da área (entendidos como feições lineares de uma superfície, mapeáveis, alinhadas de forma retilínea ou levemente curvadas) foram extraídos a partir de duas técnicas: i) fotogeologia com uso de estereoscópio de mesa; e ii) extração de lineamentos de mapas de sombreamento de relevo obtidos de diferentes rumos de iluminação do MDT.

Para a fotogeologia foram usados fotos pareadas e sobrepostas em um terço, datadas de 1972, em escala 1:60.000, com uso de estereoscópio de mesa. A metodologia proposta por Liu (1987) foi aplicada à análise e à separação dos vários sistemas de lineamentos. Com isso foi possível o traçado dos lineamentos em escala de maior detalhe. Os limites da foto aérea utilizada não correspondem aos da área delimitada para o estudo de detalhe. Neste sentido, as estruturas extraídas da fotogeologia não foram usadas para a confecção de mapas 
morfométricos (densidade de lineamentos), e os resultados da técnica não foram quantificados em rosetas ou outros meios, sendo utilizados principalmente como comparação com os lineamentos extraídos do sombreamento do relevo composto.

Para a identificação e extração dos lineamentos de sombreamento do MDT foram empregadas quatro diferentes rumos de iluminação: i) W para E; ii) NW para SE; iii) N para S; e iv) NE para SW, todos com elevações de iluminação de $45^{\circ}$. Os lineamentos extraídos foram confrontados e os duplicados foram apagados, evitando-se o falseamento estatístico. Estes lineamentos foram "vetorizados" com uso do programa Arcview (ESRI) e em seguida estes vetores foram utilizados na confecção do mapa de densidade de lineamentos. Os dados vetorizados também foram tratados no programa Arcview (ESRI), com uso de scripts, para se obter as direções dos lineamentos e, em seguida, com o uso do programa Stereonett, foram gerados diagramas de roseta com 18 classes (de 10 em 10 ), um classificado pela quantidade de lineamentos e outro pelo comprimento relativo de lineamentos.

\subsubsection{Declividade e orientação de vertentes}

Os mapas de declividade e de orientação de vertentes são gerados diretamente a partir do MDT. O mapa de declividades ilustra a variação da inclinação da topografia (superfície da área) enquanto que o de orientação de vertentes fornece a variação do sentido de maior declive da área, indicando normalmente o rumo do escoamento da água em diversos pontos da área.

O mapa de declividades foi obtido a partir da diferença da variação da altitude em função da distância horizontal, ou seja, a $1^{\circ}$ derivada vertical:

$$
\text { Declividade }=\int(X, Y) \partial Z
$$

$$
\text { Onde: } \quad \begin{array}{ll}
\mathrm{X}=\text { direção } \mathrm{x} \text { (norte-sul) } \\
\mathrm{Y}=\text { direção y (leste-oeste) } \\
\mathrm{Z}=\text { direção } \mathrm{z} \text { (vertical) }
\end{array}
$$

O mapa de orientação de vertentes foi obtido a partir da primeira derivada horizontal do MDT, onde: 


$$
\text { Orientação das vertentes }=\int(X, Z) \partial Y, \int(Y, Z) \partial X
$$

Onde: $\quad X=$ direção $x$ (norte-sul)

$Y=$ direção y (leste-oeste)

$Z=$ direção $Z$ (vertical)

Para confeccionar os mapas foi empregado o programa Arcview (ESRI), que aplica o cálculo de derivada diretamente sobre o MDT:

i) o uso da equação 2.1 sobre o MDT forneceu valores da inclinação do terreno para cada pixel da imagem, variando de $0^{\circ}$ até a inclinação máxima de $20^{\circ}$, podendo assim ser feito um mapa de declividades;

ii) a aplicação da equação 2.2 sobre o MDT forneceu valores de azimute para cada pixel da imagem, os quais em seguida foram organizados em classes de $45^{\circ}$ para gerar o mapa de orientação de vertentes.

\subsubsection{Superfícies de base}

O mapa de superfícies de base permite indicar contrastes no comportamento do relevo, que podem representar blocos distintos relacionados a processos tectono-erosivos diferentes, apontando movimentações recentes da crosta (Filosofov 1960, apud Golts \& Rosenthal 1993).

A elaboração do mapa de superfícies de base requer primeiramente a hierarquização da rede de drenagem. Em seguida necessita-se de uma interpolação da intersecção das drenagens de segunda ordem e ordens maiores com as curvas de nível do terreno, a partir da qual pode ser obtido um mapa de isovalores. No presente trabalho, o mapa de superfícies de base foi gerado com o auxílio do programa Arcview (ESRI), desde a aquisição e hierarquização da rede de drenagens (Grohmann 2004), até a interpolação da intersecção das drenagens de segunda ordem com as altitudes. 


\subsubsection{Densidades de lineamentos e de drenagens}

Os mapas de densidades de lineamentos e densidades de drenagens são obtidos pela razão entre o comprimento linear destes atributos e a área de uma célula definida para o local. Para a elaboração desses mapas foi empregado o programa Arcview (ESRI). Para a extração das feições lineares foram utilizados o mapa de lineamentos estruturais georreferenciado, para a elaboração do mapa de densidade de lineamentos, e o mapa de drenagens, para gerar o mapa de densidade de drenagens. No processamento dos dados obtem-se a somatória do comprimento total das feições lineares (lineamentos e/ou drenagens) de uma célula e atribui-se estes valores a células com área pré-definida, no caso de $500 \times 500 \mathrm{~m}$. A interpolação dos dados foi realizada dentro da área da fronteira convexa dos dados (Eddy 1977), pelo método de splines regularizadas com tensão (Mitasova \& Mitas, 1993, Mitasova \& Rofierka, 1993).

\subsubsection{Rugosidade de relevo}

O mapa de rugosidade de relevo (Hobson 1972, Day 1979) tem como base a razão da área da superfície real pela superfície planar. Hobson (1972) definiu genericamente rugosidade de terreno como o índice de irregularidade ou a variabilidade não sistemática da elevação do terreno.

O mapa de rugosidade de relevo foi obtido dividindo-se o mapa em células de 30×30 m e calculando-se a razão entre a superfície real e a superfície planar de cada célula. A área real da célula foi calculada usando o programa Arcview (ESRI), usando a equação:

Área real da célula $=30 \times \sqrt{(\tan (A) \times 30)^{2}+30^{2}}$

Onde: $A=$ declividade da célula

* Equação válida para resolução espacial de 30 m.

Os valores da razão são atribuídos ao centro da célula com resolução espacial de $30 \mathrm{~m}$, sendo em seguida gerado um mapa de isovalores. 
Day (1979) sugeriu a utilização desta variável como critério para comparação e classificação de terrenos cársticos.

\subsection{Perfis de eletrorresistividade}

O método de eletrorresistividade consiste na indução e captação de corrente elétrica no solo por eletrodos. Os valores de intensidade da corrente aplicada (amperagem), a diferença de potencial medido (voltagem) e o coeficiente $\mathrm{K}$ do arranjo geométrico dos eletrodos permitem o cálculo da resistividade aparente do solo, que é atribuído a um determinado ponto em sub-superfície de acordo com os arranjos geométricos pré-definidos (Telford 1990).

O método de eletrorresistividade pode ser aplicado em sondagens elétricas verticais (SEV), que indicam contrastes horizontais de propriedades elétricas em sub-superfície. O método também pode ser aplicado em caminhamentos elétricos, que indicam contrastes verticais. Novamente o arranjo geométrico dos eletrodos implicará na obtenção dos resultados.

Os caminhamentos elétricos mostram contrastes verticais de propriedades elétricas. Portanto são indicados para caracterização de estruturas verticais, como fraturas sub-verticais saturadas, diques etc.

Devido à necessidade da detecção de contrastes elétricos verticais, o método escolhido para o levantamento foi o caminhamento elétrico.

Em 2004 a empresa Alta Resolução Geologia e Geofísica conduziu um estudo geofísico na área de detalhe A. O objetivo foi identificar estruturas geológicas associadas a anomalias mediante o emprego de seções $2 \mathrm{D}$ de resistividade elétrica. Ao todo 7 perfis (perfis de $A$ até $G$ ) foram levantados, com direções e intersecções pré-definidas, com intuito de se efetuar uma interpretação em 3 dimensões.

Os equipamentos utilizados na aquisição dos dados de eletrorresistividade foram uma fonte de energia (conversor DC/DC da marca Tectrol modelo TCD 1000/12), bateria $12 \mathrm{~V}$ (com capacidade de geração de até $1000 \mathrm{~V}$ com corrente 
de $1 \mathrm{~A}$ ), eletrodos de aço inoxidável com fios de cobre $\left(1,5 \mathrm{~mm}^{2}\right)$, miliamperímetro (marca Metex, modelo 3800) e milivoltímetro (marca Fluke, modelo 70-III).

O arranjo de eletrodos utilizado neste trabalho foi o dipolo-dipolo, no qual os eletrodos $A$ e $B$ de envio de corrente e os eletrodos $M$ e $N$ de potencial ou de recepção são alinhados sobre um mesmo perfil. $O$ arranjo é definido pelos espaçamentos $X=A B=M N$. A profundidade de investigação teoricamente corresponde a metade de $\mathrm{R}$ (figura 2.2); desta maneira, a profundidade deve aumentar com o aumento de R.

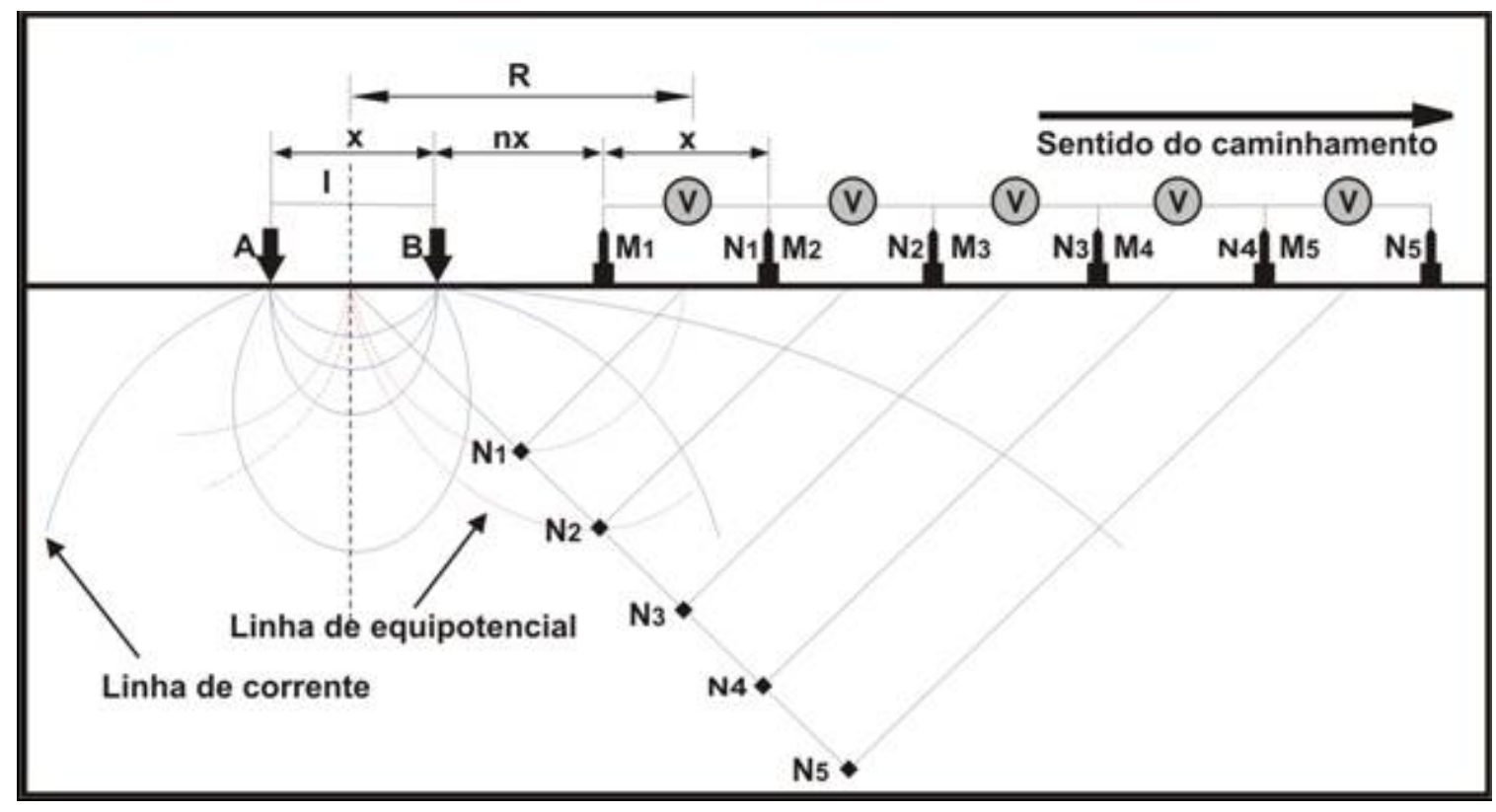

Figura 2.2 - Arranjo dipolo-dipolo utilizado no caminhamento elétrico.

A cada estação de medida os dois dipolos são deslocados a uma distância igual a $X$, e os dados obtidos são plotados nas posições $n=1,2,3, \ldots$ e interpolados, gerando uma pseudo-seção de resistividade aparente.

O caminhamento elétrico dipolo-dipolo foi realizado com espaçamento entre eletrodos igual a $20 \mathrm{~m}$, com exceção da seção $\mathrm{E}$, onde o espaçamento de $30 \mathrm{~m}$ foi adotado com intuito de investigar substratos mais profundos. Em todas as seções foram executados cinco níveis de investigação. 
Após a aquisição e tratamento dos dados, os valores de resistividade aparente foram dispostos em pseudo-seções de resistividade aparente, que apresentam distorções devido à geometria do arranjo dos eletrodos. Desta forma, uma pseudo-seção de resistividade aparente é modelada pelo processo de inversão, o qual corrige as distorções inerentes ao método e tende a aproximar a imagem 2D à situação real, de maneira a facilitar a interpretação (Telford 1990).

As pseudo-seções foram invertidas com uso do software RES2DMOD (Loke 1999). Os dados tratados foram aplicados a seções 2D e interpolados com uso do programa computacional Surfer 7.0 (Golden software).

\subsection{Levantamentos de campo}

Os levantamentos de estruturas no campo foram realizados com o intuito de caracterizar as estruturas tectônicas rúpteis (falhas e juntas), quanto às suas atitudes e superposições relativas. Com estas informações foi organizado um banco de dados estruturais, que serviu de base para descrição, qualificação e quantificação dos eventos deformacionais rúpteis da área de estudo. Em paralelo, foi efetuada a verificação da validade dos resultados obtidos na análise morfométrica e de extração de lineamentos do MDT.

Aos dados provenientes dos levantamentos de campo, foram aplicados métodos gráficos para a determinação de paleotensões a partir de populações de falhas, conforme propostos por Angelier \& Mechler (1977) e Angelier (1994). Para as juntas, a determinação de paleotensões seguiu os pressupostos de Hancock (1985), Hancock \& Engelder (1989) e Dunne \& Hancock (1994).

Apesar do estado de alteração das rochas e dificuldade de acesso às regiões pré-definidas, foram obtidos 187 dados estruturais planares (juntas, falhas e foliações), distribuídos aproximadamente por toda a região, e que podem ser considerados representativos para estabelecer uma boa aproximação do padrão de deformação rúptil da área. As estruturas obtidas nos trabalhos de campo são apresentadas no Anexo II - Tabela 1. 


\subsubsection{Análise de famílias de juntas}

No presente trabalho o termo "junta" refere-se a uma fratura que em escala de observação de campo não apresenta preenchimento ou indicações de movimentação dos blocos adjacentes (Hancock 1985). Para o uso das juntas para análise tectônica é preciso que estas apresentem caráter sistemático (Hodgson 961), ou seja, juntas aproximadamente planas que compõem famílias. Segundo Dunne \& Hancock (1994) uma família de juntas não implica num paralelismo absoluto das estruturas, mas implica numa constante relação angular entre as juntas da mesma família e uma outra tendência regional das estruturas. Neste contexto, juntas sistemáticas são formadas por famílias de juntas que se apresentam dispostas simetricamente ao redor de eixos imaginários de esforços ou "trends" estruturais regionais. Angelier (1984) propôs que duas famílias de juntas podem ser consideradas conjugadas quando: i) são formadas sob o mesmo campo de esforços; ii) são contemporâneas; iii) foram formadas em ambiente rúptil em um corpo de rocha mecanicamente intacto; e iv) propagam-se ao longo de planos cujas orientações são compatíveis com os critérios de ruptura de MohrCoulomb.

Juntas geradas sob mesmo regime tectônico indicam a direção de esforço horizontal máximo responsável pela sua geração. Conforme a classificação de Dunne \& Hancock (1994), a direção de esforço horizontal máximo (SHmáx) está localizada na bissetriz aguda das atitudes dos planos das juntas, e o esforço horizontal mínimo (Shmín) na bissetriz obtusa, restando o eixo ortogonal aos dois

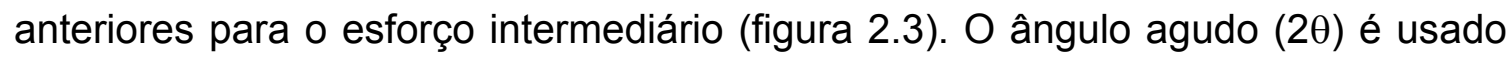
para classificar a família em juntas, em: i) de distensão $\left(2 \theta<10^{\circ}\right)$; ii) conjugadas híbridas $\left(10 \leq 2 \theta \leq 50^{\circ}\right)$; e iii) conjugadas de cisalhamento $\left(2 \theta>50^{\circ}\right)$. 


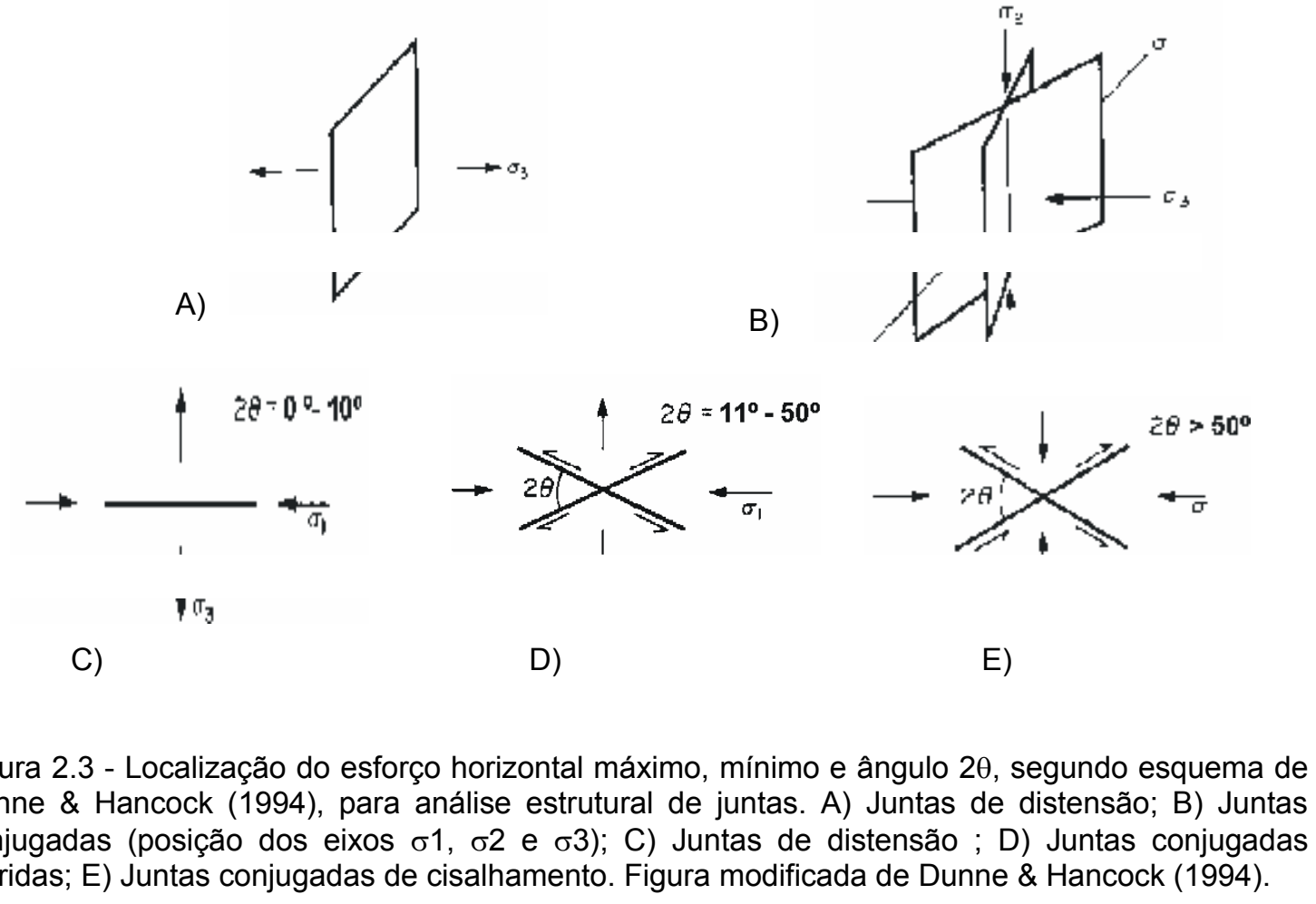

A utilização de famílias de juntas como indicadores tectônicos já foi aplicada com sucesso no Brasil em estudos de maciços de rochas alcalinas (Riccomini 1995, Ferrari 2001, Chiessi 2004) e de rochas sedimentares de bacias cenozóicas do sudeste do Brasil (Hiruma 1999, Salvador \& Riccomini 1995).

\subsubsection{Falhas como indicadores tectônicos}

Neste trabalho, o termo falha é utilizado para classificar fraturas para as quais em escala de campo pode ser constatado um deslocamento relativo entre os blocos por ela separados. Este movimento ocorreu com vetor principal paralelo à fratura (representado na falha pela estria). Neste sentido, apenas foram cadastradas como falhas aquelas estruturas cujas estrias puderam ser observadas e medidas. Em paralelo, procurou-se também observar feições que indicassem os sentidos de movimento relativo entre os blocos. Com os dados de planos, estrias e sentido de movimento das falhas foi possível a aplicação de métodos gráficos para determinação das paleotensões. 
Os dados de falhas e estrias foram analisados empregando-se o método gráfico dos diedros retos (Angelier \& Mechler 1977, Angelier 1994). Este método parte do pressuposto de que falhas geradas em um mesmo episódio tectônico, observadas em um maciço com fraturamento preexistente, apresentam movimentação resultante de um estado de tensões médio. Sendo assim, pode-se determinar os três eixos desse estado de tensões. Para o método, as estrias de atrito representam a componente cisalhante do esforço sobre o plano de falha. Para cada plano de falha e respectiva estria é construído um plano auxiliar, ortogonal à estria e ao plano de falha. Esse plano auxiliar e o plano de falha delimitam no espaço quatro diedros, que são dois diedros opostos para a compressão e os outros dois opostos para a distensão (figura 2.4), e que são definidos pelo sentido de movimento da falha. Esses planos são plotados em diagramas de Schmidt-Lambert e cada par plano/estria com respectivo plano auxiliar são somados nos diagramas. Dessa maneira, são definidas áreas de maior coincidência de campos compressivos, onde tem-se a maior probabilidade de conter o eixo $\sigma 1$. Conseqüentemente, na área de coincidência de campos distensivos ter-se-á maior probabilidade de ocorrência do eixo $\sigma 3$.

A)

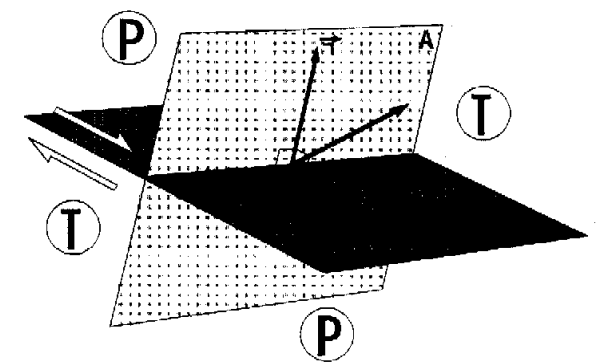

B)

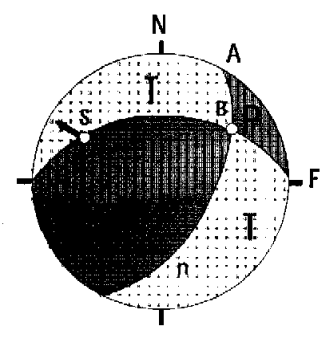

Figura 2.4 - Princípio do método gráfico dos diedros retos (Angelier \& Mechler 1977, Angelier 1994). A) intersecção do plano de falha com seu plano auxiliar, dividindo o espaço em quatro diedros, sendo dois opostos compressivos e dois distensivos. B) Projeções estereográficas dos planos de "A", mostrando os diedros compressivos $(P)$ e distensivos (T) (modificado de Angelier 1994). 
O programa StereoNett (versão livre 2.46) foi empregado na obtenção dos campos de esforços responsáveis pela geração de estruturas tectônicas rúpteis, mediante o método gráfico dos diedros retos.

Como premissa para a aplicação do método gráfico com programas de computadores é preciso que as estrias estejam contidas nos planos de falha, quesito que freqüentemente não é atendido com as medidas de campo, tendo em vista os erros inerentes à medição. Portanto, torna-se necessário o tratamento dos dados pareados de falha e estria, corrigindo-se as atitudes das estrias segundo a melhor precisão das medidas com bússola tipo Clar. Desse modo, os dados estruturais pareados (falha e estria) foram corrigidos no programa StereoNett (versão livre 2.46), segundo critérios abaixo relacionados:

- para planos de falha com mergulhos maiores do que $70^{\circ}$, prioriza-se o valor do mergulho da estria;

- para planos com mergulhos menores do que $45^{\circ}$, dá-se a preferência à direção da estria;

- para planos com mergulhos intermediários, opta-se por um ajuste médio nos dois valores (direção e mergulho).

O método gráfico pressupõe que as falhas analisadas tenham sido geradas no mesmo evento. Portanto, tornou-se necessária a classificação dos dados em famílias, que representam diferentes episódios tectônicos. Esta classificação se deu pelas relações de superposição das estruturas e teste de compatibilidade pelo exame das atitudes dos planos das falhas, atitudes das estrias e sentidos de movimentos das falhas. Outra maneira, menos recomendada (e não empregada neste estudo), é aplicar o método gráfico de forma aproximada para falhas com atitudes parecidas, e agrupá-las de acordo com seus campos de esforços.

\subsubsection{Indicadores cinemáticos rúpteis}

A aplicação do método gráfico de Angelier \& Mechler (1977) exige a determinação do sentido de movimento da falha, se normal, reversa, sinistral, dextral ou combinações direcionais, por meio da identificação dos indicadores 
cinemáticos rúpteis. Normalmente são usados marcadores estratigráficos, dobras de arrasto, feições de assimetria entre a capa e a lapa, e deslocamento relativo entre marcadores (como exemplo um seixo). Para o caso dos maciços estudados, tendo em vista a natureza relativamente homogênea de suas rochas, tornou-se necessária a aplicação de indicadores cinemáticos nas superfícies de falhas, baseados em Angelier (1994) (figura 2.5):

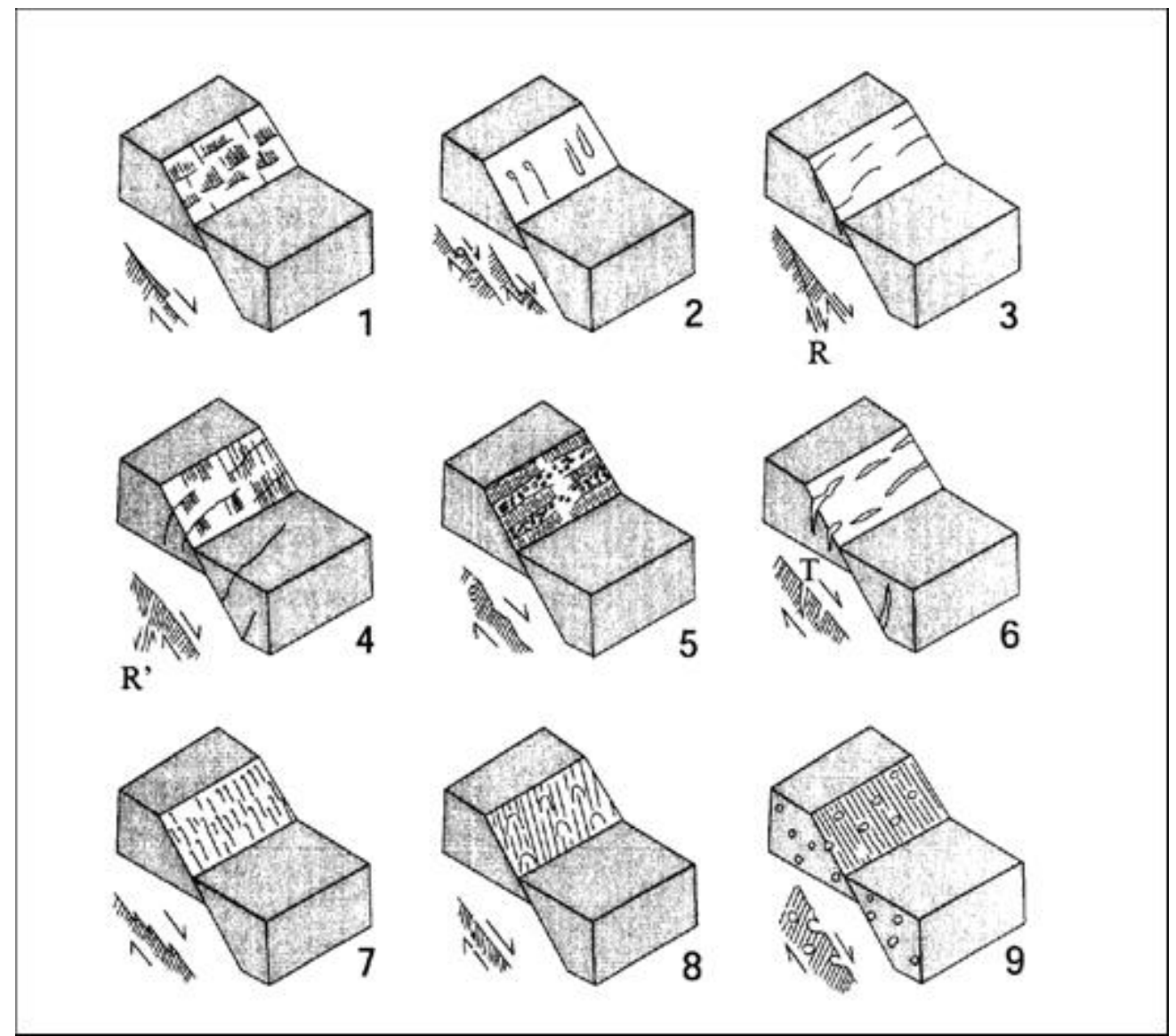

Figura 2.5 - Critérios para determinação do sentido do movimento em superfícies de falhas, válidos para qualquer tipo de movimento ocorrido. 1) Degraus de minerais neoformados; 2) marcas de objetos; 3) fraturas de cisalhamento sintéticas (R); 4) fraturas de cisalhamento antitéticas (R'); 5 ) facetas polidas e rugosas alternadas; 6) tension gashes; 7) picos estilolíticos; 8) marcas parabólicas e 9) vesículas deformadas em lavas. Figura modificada de Angelier (1994).

Os critérios para determinação de movimentos relacionados na figura 2.5 são apresentados a seguir:

1) degraus de minerais neoformados, gerados pelo crescimento de cristais durante o movimento da falha, com $100 \%$ de confiabilidade; 
2) marcas de objetos tectônicos, tais como grãos de quartzo, feldspato e seixos, que ocorrem tanto como um relevo positivo ou como cavidades assimétricas na superfície de falha, com confiabilidade de $85 \%$;

3) planos sintéticos $(R)$ de Riedel shears, que cruzam o plano de falha com ângulos entre $5-25^{\circ}$, no mesmo sentido de movimento da falha, e são aproximadamente perpendiculares às lineações no plano de falha, apresentam confiabilidade de $75 \%$;

4) planos antitéticos ( $\left.R^{\prime}\right)$ de Ridel shears, que cruzam o plano de falha com ângulos em torno de $75^{\circ}$, apresentam sentido de movimento oposto ao da falha, e são aproximadamente perpendiculares às lineações no plano de falha, a confiabilidade é de $75 \%$;

5) facetas polidas e rugosas, que podem ocorrer em todos os tipos de rochas, sendo mais comuns nas rochas não carbonáticas; são freqüentemente perpendiculares à direção de movimento e os principais tipos de facetas são com fricção (polida e estriada, ou moída e esbranquiçada, sendo que essas últimas podem ser confundidas com fibras), com abertura (rugosa, localmente com fragmentos de rochas, óxido de ferro, calcita e quartzo), apresentam confiabilidade de $80 \%$;

6) tension gashes - planos $T$ de Riedel, que apresentam ângulos de 30 a $50^{\circ}$ com o plano de falha e dispõem-se em posição aproximadamente perpendicular às lineações, possuem confiabilidade de $70 \%$;

7) picos ou lineações estilolíticas, produzidos por solução em facetas friccionais, e que $100 \%$ confiáveis em calcário;

8) marcas parabólicas, comumente desenvolvidas em superfícies de falhas polidas, e que mostram formas em meia lua com concavidade voltada no sentido do movimento do bloco ausente; representam lascas arrancadas pelo movimento, aproveitando fraturas antitéticas que fazem um ângulo alto com o plano de falha, normalmente fraturas $\mathrm{T}$; 
9) vesículas deformadas em lavas, formação de cornijas, a favor do movimento, e de concavidades, contra o movimento, na borda de orifícios vesiculares, por cataclase na superfície de falha.

As feições de assimetria registradas pelo movimento relativo nos planos de falhas dividem-se em assimétricas positivas e negativas. As positivas apresentam, no plano de falha, uma menor rugosidade ao tato no sentido de movimento do bloco ausente. As negativas apresentam maior rugosidade ao tato no sentido do bloco ausente.

\subsection{Perfuração e instalação dos poços de monitoramento do aqüífero fraturado}

Foram instalados no aqüífero fraturado 15 poços de monitoramento ambiental, sendo 11 deles na área de detalhe $A$ (PMR-01 a 11) e quatro na área de detalhe $B$ (PMR-12 a 15). Adicionalmente, a área de detalhe $A$ contava com um poço de produção de água. As localizações dos poços de monitoramento foram definidas de acordo com o interesse das investigações de cunho ambiental realizadas nas áreas de detalhe.

A área de detalhe $A$ contou com três etapas de investigação, com instalação de poços de monitoramento no aqüífero cristalino fraturado. Durante a primeira etapa das investigações, foram instalados cinco poços verticais (PMR-01 a 04 e PMR-11), e nestes foram identificados três famílias de fraturas, incluindo uma família de fraturas sub-verticais.

$\mathrm{Na}$ segunda etapa, devido à presença de família de estruturas sub-verticais, decidiu-se instalar três poços (PMR-05, 06 e 07) com inclinação de $60^{\circ}$ em relação a horizontal, com intuito de aumentar o número de fraturas a serem interceptadas pela perfuração. As direções das perfurações foram selecionadas de forma a maximizar o cruzamento com as famílias de fraturas identificadas, tanto na primeira etapa de investigação (BHTV), quanto àquelas identificadas no estudo de fotogeologia da área. 
Para complementar a rede de monitoramento do aqüífero fraturado na área de detalhe $A$, foi realizada uma investigação adicional contando com a instalação de outros três poços inclinados em $60^{\circ}$ (PMR-08 a 10).

$\mathrm{Na}$ área de detalhe $\mathrm{B}$ foram instalados quatro poços de monitoramento inclinados de $60^{\circ}$ em relação a horizontal no aqüífero cristalino fraturado (PMR-12 a 15). A localização e atitude dos poços foram definidas com intuito de montar uma rede de monitoramento ambiental do aqüífero fraturado, com base na interpretação de fotografias aéreas, afloramentos de rocha nas proximidades e no conhecimento das estruturas observadas na área de detalhe $\mathrm{A}$.

Devido ao caráter ambiental da construção dos poços, todas as perfurações na rocha são realizadas somente após a construção de um selo sanitário, para garantir que não ocorra migração de possíveis compostos presentes no aqüífero poroso raso para o aqüífero cristalino fraturado.

As etapas da perfuração consistiram em: i) perfuração do solo empregando broca tricônica com 7 polegadas de diâmetro, e revestimento de sondagem com diâmetro interno de 8 polegadas, até atingir o topo do maciço rochoso; ii) construção do selo sanitário, que consiste na perfuração do topo do maciço rochoso de aproximadamente 0,5 metros, com diâmetro de 7 polegadas; em seguida são instalados tubos de aço costurado com 5 polegadas de diâmetro e 6 metros de comprimento, soldados uns aos outros, desde a superfície até o interior da perfuração de 7 polegadas; a seguir, injeta-se calda de cimento líquido entre a parede do furo de 7 polegadas e o tubo de aço; a perfuração na rocha tem início após a cura parcial do cimento; III) perfuração na rocha, com diâmetro de 4,5 polegadas, com a utilização de martelo roto-pneumático, até a profundidade determinada. A figura 2.6 a seguir exemplifica o perfil construtivo dos poços. 


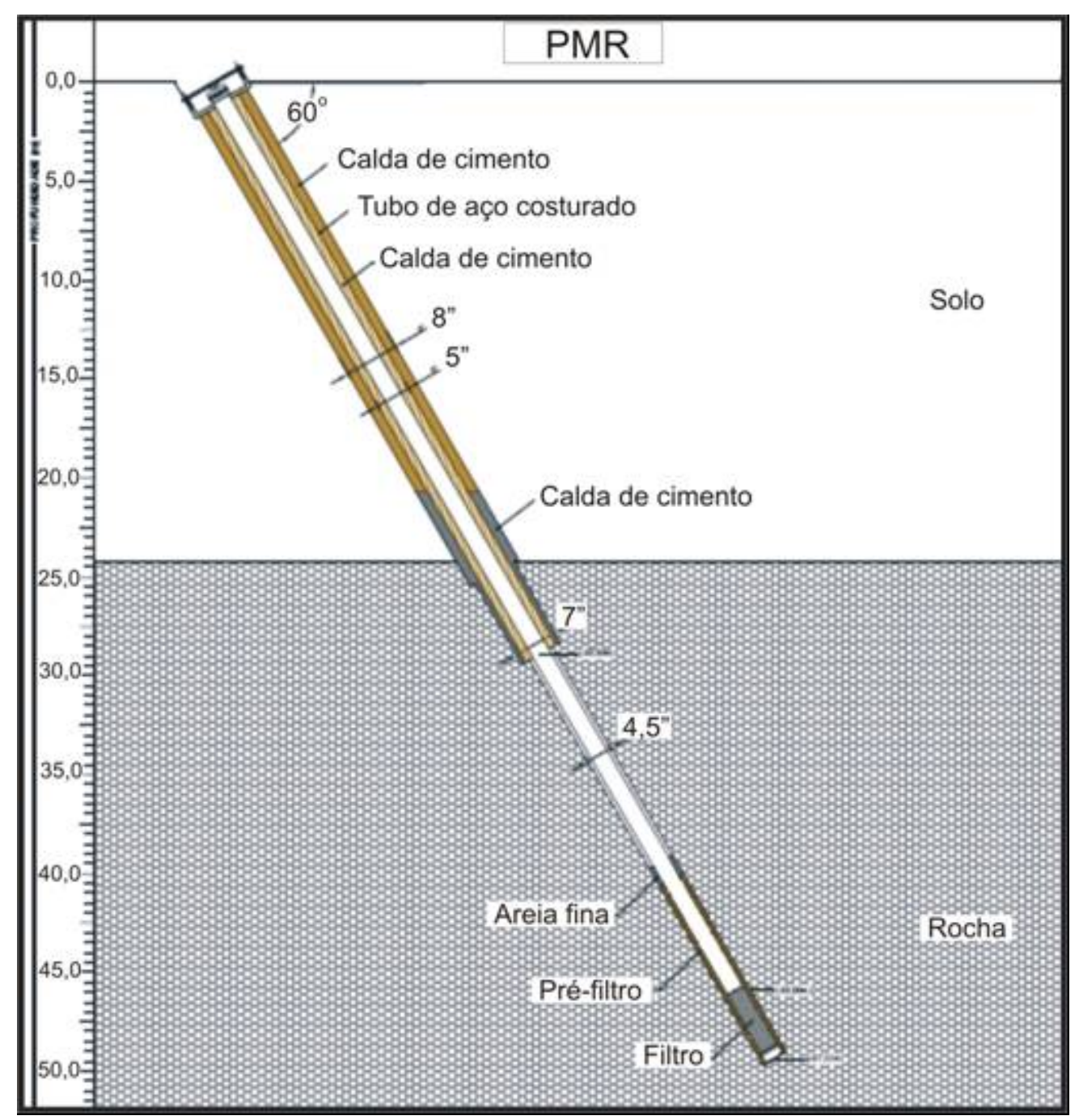

Figura 2.6 - Perfil construtivo de poço inclinado no embasamento cristalino.

A definição da seção do filtro foi baseada em uma análise de estruturas orientadas (BHTV) e anotações de campo durante as perfurações, com foco nas principais zonas fraturadas com entrada de água subterrânea. Devem ser instalados tubos isolando as fraturas ou zonas fraturadas de interesse, para que a perfuração não permaneça aberta conectando fraturas ou zonas fraturadas, formando assim um potencial caminho de migração vertical de compostos de interesse ambiental. Desta maneira, após a análise das estruturas orientadas obtidas por meio de BHTV (item 2.7) e da identificação das principais seções fraturadas, as tubulações e seções filtrantes dos poços foram instaladas. 
As informações relativas à direção, inclinação, profundidade e seção do filtro dos antigos e novos poços de monitoramento no aqüífero fraturado estão apresentadas na Tabela 2.1.

\begin{tabular}{||c|c|c|c|c|c||}
\hline Poço & Orientação & $\begin{array}{c}\text { Profundidade } \\
\text { linear }(\mathbf{m})\end{array}$ & $\begin{array}{c}\text { Profundidade } \\
\text { vertical }(\mathbf{m})\end{array}$ & $\begin{array}{c}\text { Comprimento } \\
\text { de tubo }(\mathbf{m})\end{array}$ & $\begin{array}{c}\text { Seção } \\
\text { filtrante }(\mathbf{m})\end{array}$ \\
\hline \hline PMR-01 A & Vertical & 55,50 & 55,50 & 39,50 & $35,5-39,5$ \\
\hline PMR-01 B & Vertical & 55,50 & 55,50 & 52,10 & $48,1-52,1$ \\
\hline PMR-02 & Vertical & 47,50 & 47,50 & 37,80 & $33,8-37,8$ \\
\hline PMR-03 & Vertical & 46,60 & 46,60 & 46,50 & $38,5-42,5$ \\
\hline PMR-04 & Vertical & 52,30 & 52,30 & 52,30 & $44,3-48,3$ \\
\hline PMR-05 & $\mathrm{N} 210^{\circ} / 60^{\circ}$ & 57,00 & 51,20 & 46,00 & $42,0-46,0$ \\
\hline PMR-06 & $\mathrm{N} 125 \% 60^{\circ}$ & 69,40 & 61,80 & 60,00 & $56,0-60,0$ \\
\hline PMR-07 & $\mathrm{N} 165 \% 60^{\circ}$ & 57,00 & 50,80 & 52,00 & $48,0-52,0$ \\
\hline PMR-08 & $\mathrm{N} 090^{\circ} / 60^{\circ}$ & 57,00 & 62,30 & 57,00 & $53,0-57,0$ \\
\hline PMR-09 & $\mathrm{N} 120^{\circ} / 60^{\circ}$ & 80,00 & 69,00 & 50,10 & $44,1-50,1$ \\
\hline PMR-10 & $\mathrm{N} 160^{\circ} / 60^{\circ}$ & 60,70 & 52,60 & 57,00 & $53,0-57,0$ \\
\hline PMR-11 & $V^{\circ}+1 c^{\circ}$ & 70,75 & 70,75 & 70,75 & $32,0-70,0$ \\
\hline PMR-12 & $\mathrm{N} 140^{\circ} / 60^{\circ}$ & 25,60 & 22,17 & 21,10 & $17,1-21,1$ \\
\hline PMR-13 & $\mathrm{N} 180^{\circ} / 60^{\circ}$ & 38,05 & 32,95 & 33,05 & $29,0-33,0$ \\
\hline PMR-14 A & $\mathrm{N} 040^{\circ} / 60^{\circ}$ & 42,85 & 37,10 & 32,00 & $30,0-32,0$ \\
\hline PMR-14 B & $\mathrm{N} 040^{\circ} / 60^{\circ}$ & 42,85 & 37,10 & 42,50 & $38,5-42,5$ \\
\hline PMR-15 & $\mathrm{N} 260^{\circ} / 60^{\circ}$ & 31,00 & 26,84 & 28,00 & $24,0-28,0$ \\
\hline \hline
\end{tabular}

Tabela 2.1 - Poços de monitoramento em meio cristalino fraturado.

Os poços de monitoramento foram instalados usando tubo de PVC geomecânico de 2 polegadas de diâmetro, com seção filtrante de 4 metros, com exceção do PMR-09, com seis metros de seção de filtro, e o PMR-11, onde não foi instalado tubo de PVC, sendo a seção filtrante de 32 a 70 metros uma exposição de rocha. Todas as seções filtrantes foram colocadas em profundidades que cobrem as zonas mais fraturadas de cada sondagem. O espaço anelar entre o furo perfurado e a seção de filtro foi preenchido com areia de pré-filtro. Acima da areia de filtro depositou-se uma calda de bentonita e cimento líqüido até atingir a superfície do solo. Uma laje protetora de concreto equipada com tampa de proteção também foi instalada. 
Após a instalação, todos os poços foram bombeados objetivando-se a remoção de sedimentos e colóides.

As perfurações verticais foram realizadas pela Hidrogesp Ltda., e as inclinadas pela empresa Geosonda S.A.. Ambas empregaram um equipamento roto-pneumático ( 8,5 polegadas no solo, e 4,25 polegadas na rocha), livre de solventes e óleo. Lama ou bentonita não foram usadas nas perfurações.

Adicionalmente, a área de detalhe A apresenta um poço de produção PP01, perfurado em 6 polegadas com 290 metros de profundidade e seção de captação de água em rocha exposta, com aproximadamente 260 metros.

\subsection{Perfilagem acústica das perfurações (técnica BHTV)}

BHTV (Bore Hole Television) é um conjunto de técnicas destinadas às prospecções dentro de perfurações. Estas técnicas incluem métodos ópticos (filmagem, filmagem orientada e fotografias), físico-químicos (medidores de fluxo, cáliper, termômetros etc.) e geofísicos (geoelétrico, acústico, sônico, espectroscopia de raios gama natural, espectroscopia de nêutrons, ressonância magnética etc.).

Os métodos BHTV mais usados para estudos de fraturas em perfurações são os que caracterizam fraturas orientadas, como a filmagem orientada e televisionamento acústico. Normalmente tais métodos são associados a técnicas de medida de fluxo em fraturas, perfis geoelétricos e perfis de raios gama natural. No presente trabalho foi utilizado nos poços de monitoramento a perfilagem acústica.

A metodologia de perfilagem por imagem acústica produz imagens orientadas baseadas nos princípios acústicos, que refletem as estruturas penetrantes, sobretudo fraturas abertas e grandes veios.

Praticamente todas as sondagens para poços (PMR-01 a 10 e 12 a 15) foram submetidas a medições geofísicas orientadas, após a perfuração dos poços no embasamento e antes da instalação dos poços de monitoramento. O principal 
objetivo foi o de identificar e orientar estruturas geológicas, sobretudo as fraturas abertas que permitem fluxo de água subterrânea.

As análises de tais estruturas serviram como base para a definição da seção do filtro de cada poço de monitoramento, além da definição do modelo geológico conceitual.

Os levantamentos ocorreram junto à perfuração e instalação dos poços. $\mathrm{Na}$ tabela 2.2 são apresentados o mês e o ano da execução dos poços, assim como um resumo das estruturas levantadas, subdivididas em fraturas abertas (juntas e falhas) e fechadas (veios, foliações e fraturas preenchidas). Na tabela 2 do anexo II são apresentados sumários das fraturas obtidas por este método, assim como suas orientações, profundidades e classificação.

\begin{tabular}{||c||c||}
\hline Poço & $\begin{array}{c}\text { Intervalo da } \\
\text { perfilagem }(\mathbf{m})\end{array}$ \\
\hline \hline PMR-01 & $37,0-50,0$ \\
\hline PMR-02 & $27,4-46,5$ \\
\hline PMR-03 & $24,3-45,5$ \\
\hline PMR-04 & $30,5-52,0$ \\
\hline PMR-05 & $27,0-52,7$ \\
\hline PMR-06 & $36,4-69,2$ \\
\hline PMR-07 & $26,5-56,5$ \\
\hline PMR-08 & $27,0-57,0$ \\
\hline PMR-09 & $29,0-80,0$ \\
\hline PMR-10 & $30,7-60,7$ \\
\hline PMR-12 & $5,6-25,6$ \\
\hline PMR-13 & $18,0-38,0$ \\
\hline PMR-14 & $22,8-42,8$ \\
\hline PMR-15 & $11,0-31,0$ \\
\hline
\end{tabular}

Tabela 2.2 - Tabela-resumo do televisionamento acústico (BHTV)

O imageamento acústico foi realizado com o sistema de perfilagem desenvolvido pela Robertson Geologging Ltda. O sistema trabalha com uma sonda (borehole televiewer) que obtém uma imagem acústica digital das paredes do furo. O diâmetro mínimo do furo é de 2,64 polegadas $(67 \mathrm{~mm})$, não pode estar revestido e deve estar com água. 
Um transdutor gira continuamente ao redor do eixo da sonda, enviando e recebendo um pulso sônico. O pulso é emitido a partir da superfície do transdutor e viaja através do fluido do furo, atingindo a parede e retornando ao transdutor. Nesse processo, são registradas as amplitudes e o tempo de propagação do pulso.

Um sistema de orientação constituído de um acelerômetro e de um magnetômetro triaxial possibilita a orientação da imagem na fase de processamento. Desta maneira não é necessário realizar correções das atitudes das fraturas identificadas.

A figura 2.7 apresenta exemplo de registro gerado a partir do programa de aquisição RGWinlogger. Deve-se salientar que as imagens geradas nesta etapa não são referenciadas geograficamente. O referenciamento azimutal ao norte apenas é possível na fase de processamento, com a utilização do programa RGLDIP. O sistema usado obtém produtos a partir do processamento, tais como: i) perfil do tempo de transito e amplitude comparada à profundidade; ii) orientação da sondagem; iii) ovalização do furo (break out); e iv) desvios da sondagem.

Todos os levantamentos de perfilagem acústica orientada foram realizados pela empresa Aquajet Consultoria, Comércio e Perfuração de Poços Tubulares Ltda. 


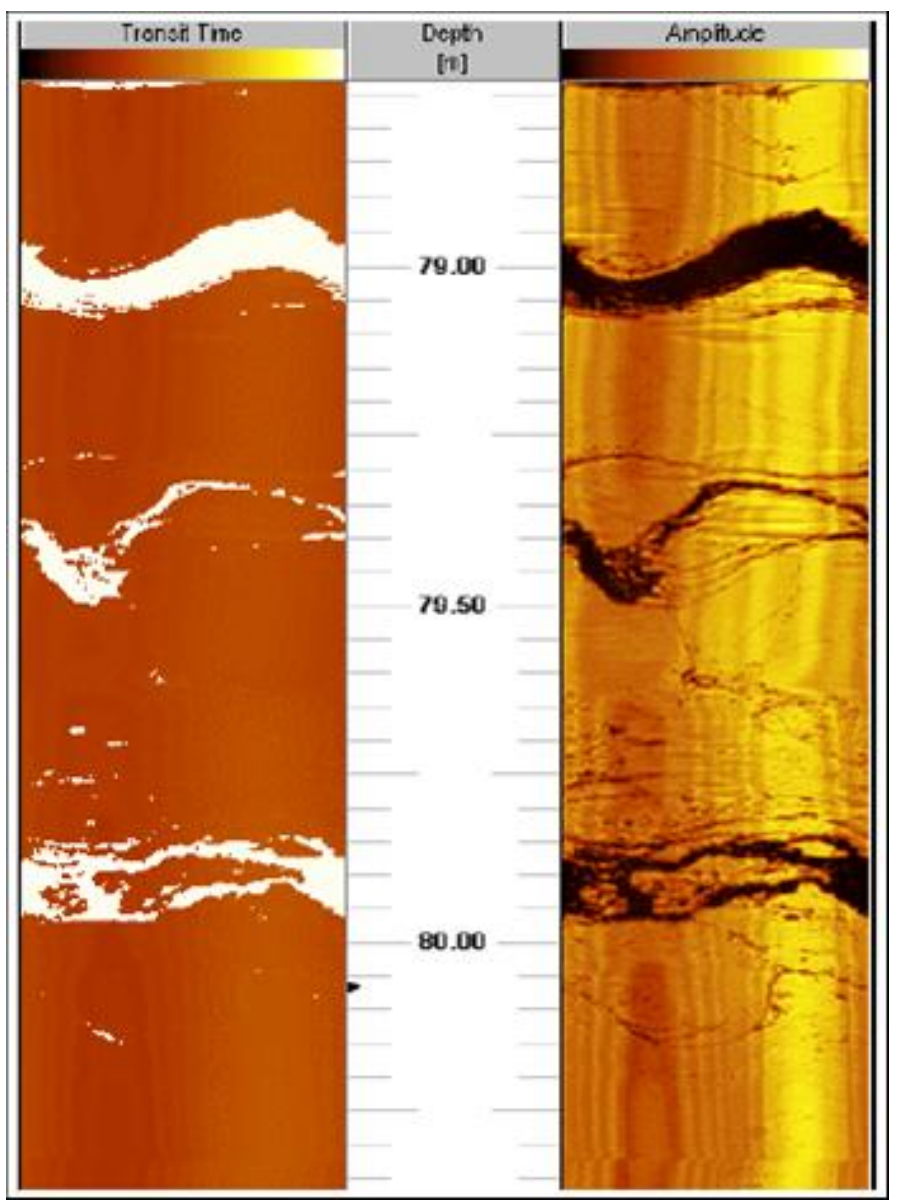

Figura 2.7 - Dados de aquisição de imagem de perfilagem acústica (esquerda: tempo de trânsito; direita: amplitude do sinal de retorno).

\subsection{Cálculo de freqüência de fraturas no maciço}

Para definir o fraturamento do maciço foi realizado um estudo comparando a quantidade de estruturas abertas (fraturas) com o total perfurado (perfilado) nas rochas do maciço. Portanto, no estudo do fraturamento do maciço foi necessário definir uma freqüência da intersecção de fraturas (FIF).

A probabilidade de a sondagem interceptar a fratura varia do valor mínimo quando as atitudes são paralelas (quando a atitude de uma linha esta contida em um plano paralelo ao plano da fratura), até um valor máximo quando as atitudes são perpendiculares. 
Por haver diferenças entre as atitudes das sondagens, entre as famílias de fraturas e entre ambas, torna-se necessário o emprego de tratamento estatístico para a ponderação dos dados de freqüência.

Para a ponderação destes dados, inicialmente foi necessário otimizar os cálculos, definindo as famílias de fraturas, e comparando-as com a atitude das sondagens que foram realizadas. Em seguida foi necessário decompor o comprimento perfurado de cada sondagem na direção perpendicular de cada família.

Para se definir a direção perfurada perpendicularmente a cada família foi calculada a abertura angular (ângulo $\alpha$ ) entre a direção da sondagem (poço) e o pólo da família da fratura (figura 2.4), para depois ser multiplicado o cosseno deste ângulo a pela distância linear perfurada.

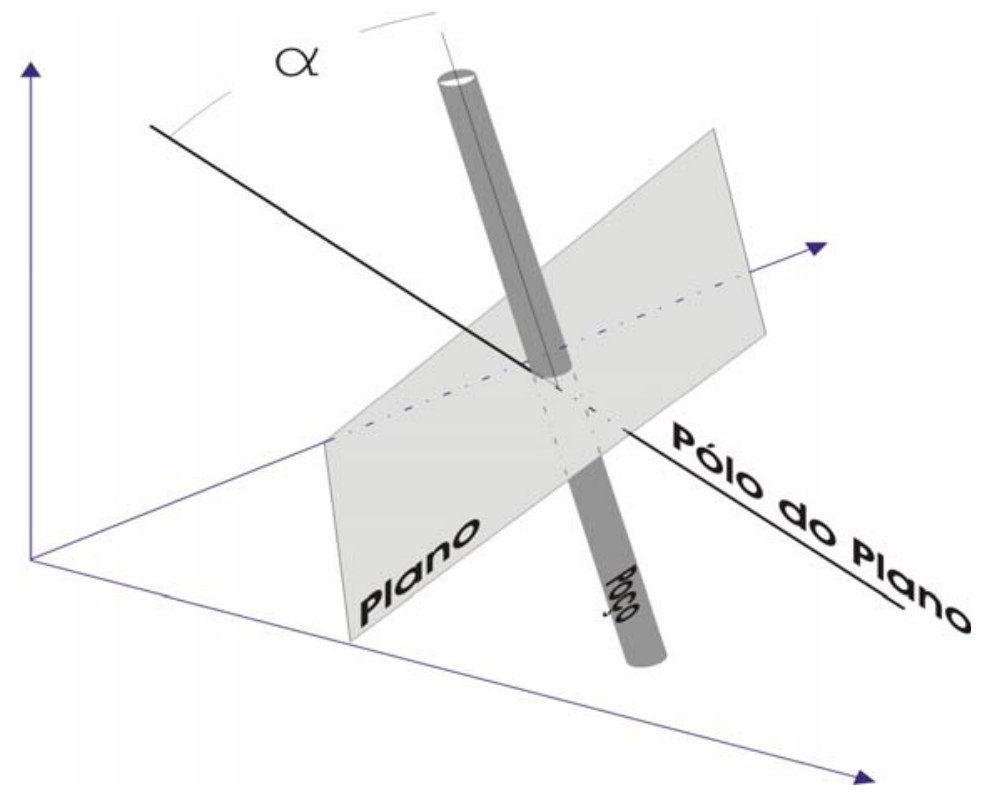

Figura 2.8 - llustração da abertura angular entre o pólo do plano e a sondagem (poço).

Para estabelecer a abertura angular entre a direção da sondagem e o pólo da família foram utilizados estereogramas e programas computacionais para manipulação de dados estruturais (StereoNett 2.46). No estereograma ajustam-se 
os pontos relativos à sondagem e ao pólo em um único grande círculo (linhas de longitude) e em seguida lê-se a abertura angular entre os pontos. Abordagem similar deve ser usada no método computacional.

Depois de calculado o comprimento do furo de sondagem na direção perpendicular à família de fratura, define-se a FIF como a razão do número de fraturas da família e o comprimento direcional da sondagem. Este valor em seguida pode ser comparado com a freqüência de fraturas por metro linear perfurado, definido pela razão entre o total perfurado (sem nenhuma ponderação) e o número de fraturas de cada família.

\subsection{Ensaios hidráulicos}

Ensaios hidráulicos são usados em estudos de aqüíferos para caracterizar as propriedades hidráulicas (condutividade hidráulica, coeficiente de armazenamento, cargas hidráulicas etc.), estabelecer conexões hidráulicas entre poços, definir direções do fluxo da água subterrânea, definir capacidade de fraturas em armazenar e transmitir água e raios de influência de bombeamentos no aqüífero.

Uma das dificuldades do estudo de aqüíferos fraturados é a grande variabilidade de suas características hidrogeológicas quando observados em escalas pequenas, apresentando maior previsibilidade quando abordado em escalas maiores. Um dos motivos desta abordagem de escala é o tamanho do Volume Representativo Elementar (REV), conforme discutido mais adiante. Portanto é necessária a correta compreensão da escala dos ensaios.

Amostras de rocha em testes de laboratório podem fornecer propriedades pontuais do aqüífero. Testes de rebaixamento e de recuperação podem apresentar propriedades num raio próximo ao poço, enquanto que ensaios de bombeamento fornecem características do aqüífero em escalas maiores. 


\subsubsection{Testes de rebaixamento e recuperação}

Testes de rebaixamento e recuperação são ensaios hidráulicos realizados em apenas um poço com objetivo de estimar transmissividade e, de maneira aproximada, o coeficiente de armazenamento. Estes ensaios hidráulicos também são conhecidos como testes "Slug" e "Bail", respectivamente. Ambos os testes consistem na avaliação da recuperação dos níveis da água subseqüentes a um distúrbio induzido. Em função do volume de água usado no distúrbio e das condições hidráulicas no poço, a estimativa torna-se pouco representativa frente ao volume de fluído na formação. Portanto estes testes não devem ser usados para determinar propriedades do aqüífero em larga escala ou para identificar heterogeneidades nas propriedades do aqüífero. Por envolver mínimo contato com a água do poço, muitas vezes sem gerar resíduo, estes ensaios são apropriados para o estudo de áreas contaminadas.

No presente trabalho optou-se por testes de recuperação (Bail teste), aproveitando-se da atividade de desenvolvimento, onde houve uma remoção da água subterrânea do poço. Após o bombeamento e conseqüente rebaixamento do nível da água, a recuperação do nível da água do poço foi monitorada para realização de testes hidráulicos de recuperação. Os ensaios de recuperação foram aplicados nos poços PMR-01 B, 02 até 07 e 12 até 15. As condutividades hidráulicas foram calculadas com o programa Aquifer Test (versão 2.5.7), com método de Hvorslev (1951).

Os ensaios de recuperação foram realizados nos poços instalados em determinadas fraturas isoladas, zonas fraturadas, ou grupos de fraturas. Desta maneira podem ser atribuídas características hidráulicas às fraturas ou zona de fraturas interceptadas pela seção filtrante.

Os ensaios não puderam ser realizados nos poços PMR-08 a PMR-10 devido a uma série de dificuldades, como a forma e a eficácia do bombeamento, e a dificuldade do monitoramento após desenvolvimento. 


\subsubsection{Ensaio de bombeamento}

Ensaios de bombeamento são testes nas quais um ou mais poços são bombeados enquanto as cargas hidráulicas do próprio poço e dos poços localizados ao redor são monitoradas. Os dados de ensaios de bombeamento podem fornecer informações sobre a conexão entre poços, caminhos preferenciais de fluxo nas fraturas, e propriedades do aqüífero (Kruseman \& de Ridder 1990, Cho et al. 2004).

Para avaliar a condutividade hidráulica, transmissividade e coeficiente de armazenamento nas proximidades do PP-01, e no topo do aqüífero fraturado próximo ao PMR-11 (Área de detalhe A), dois testes de bombeamento foram realizados no PP-01 e PMR-11. Os testes foram conduzidos em fevereiro de 2004.

O teste no PP-01 foi realizado com uma vazão de $2 \mathrm{~m}^{3} / \mathrm{h}$, e duração de 7 horas contínuas. No PMR-11 o teste foi conduzido por 12 horas usando vazões variando entre $2,4 \mathrm{~m}^{3} / \mathrm{h}$ (no início) e $0,5 \mathrm{~m}^{3} / \mathrm{h}$ (final). Embora usualmente um ensaio de bombeamento exija entre 24 e 72 horas, este ensaio pode ser realizado uma vez que o poço estava sob bombeamento anterior, e não foi necessário drenar a água da zona vadosa do aqüífero.

Durante o ensaio no PP-01 o nível da água subterrânea no poço PMR-11 foi monitorado por transdutores de pressão (Level logger Solinst modelo LTF100/M30), para que os dados pudessem ser usados nos cálculos dos parâmetros hidráulicos do aqüífero no entorno dos poços. Para obter os parâmetros pretendidos os dados foram tratados com uso do programa Aquifer Test (versão 2.5.7), utilizando a técnica de Cooper \& Jacob (1946).

Foi realizado um teste de bombeamento, no poço PP-01, na área de detalhe A, por 96 horas. A bomba foi instalada a uma profundidade de aproximadamente 175 metros, e a taxa de bombeamento foi de aproximadamente $3 \mathrm{~m}^{3} / \mathrm{h}$ (capacidade máxima). Aproximadamente $250 \mathrm{~m}^{3}$ de água subterrânea foram bombeados. 
Os poços de monitoramento PMR-01 a 07 e PMR-11 tiveram suas cargas hidráulicas monitoradas antes, durante e após o ensaio. Alguns dados foram obtidos medindo-se o nível da água manualmente, e outros com emprego de transdutores de pressão (Level logger Solinst modelo LT-F100/M30). Os dados de transdutores de pressão foram compensados da variação da pressão atmosférica e tratados no programa computacional Levellogger (versão 3.06, Solinst).

Os resultados foram plotados em gráficos (carga hidráulica em relação ao tempo, e comparados ao período de bombeamento) elaborados com uso do programa Excel (Microsoft Office 1997). Os dados deste ensaio não foram utilizados para definir parâmetros hidrogeológicos do aqüífero, devido a problemas na aquisição dos dados de nível da água do poço bombeado, e também pelo fato de que o principal produto almejado foi a observação de prováveis conexões hidráulicas entre os poços de monitoramento.

\subsubsection{Monitoramento das cargas hidráulicas}

O monitoramento das cargas hidráulicas nos poços PMR-08 a 10 foi efetuado nas duas áreas de detalhe, em períodos distintos, e com intuito de avaliar a influência da precipitação pluviométrica nas cargas hidráulicas dos poços. O objetivo do ensaio foi avaliar a conexão hidráulica relativa entre os poços por meio das tendências de variação das cargas dos poços em função do tempo, de seu posicionamento, e das fraturas nas quais as seções filtrantes estão instaladas.

Os valores das cargas foram obtidos medindo-se o nível da água dos poços manualmente, e por meio de transdutores de pressão (Level logger Solinst modelo LT-F100/M30). Os dados foram compensados da variação da pressão atmosférica e tratados com o emprego do programa Levellogger (versão 3.06 Solinst).

Os resultados do monitoramento foram comparados com dados pluviométricos obtidos no posto metereológico mais próximo das áreas de detalhe, em Ibiúna, SP (471' $\mathrm{W}$ e $23^{\circ} 40^{\prime} \mathrm{S}, 850 \mathrm{~m}$ de altitude), a aproximadamente $25 \mathrm{~km}$ 
de distância. A fonte dos dados foi a CIIAGRO - Instituto Agronômico de Campinas, SP, disponíveis no endereço da internet: www.iac.sp.gov.br. 


\section{HIDROGEOLOGIA DE AQÜÍFEROS EM MEIO FRATURADO}

Considera-se como aqüífero uma unidade geológica permeável e saturada que tem a capacidade de armazenar e transmitir significativas quantidades de água (Freeze \& Cherry 1979). Os aqüíferos podem ocorrer em qualquer tipo de rocha: sedimentares carbonáticas ou clásticas, vulcânicas e cristalinas. Estas rochas variam em porosidade primária e secundária (clásticas com ou sem cimentação), permeabilidade primária e secundária (fraturamento, formação de condutos cársticos), estruturas formadas durante a gênese da rocha (estratificações e separação de derrames). Desta maneira, diferentes tipos de aqüífero podem ser formados.

Neste trabalho serão abordados os aqüíferos em meios cristalinos fraturados, que apresentam matriz de permeabilidade primária muito baixa, mas com fraturas (permeabilidade secundária) que exercem o papel de armazenar e transmitir a água subterrânea de maneira que a unidade geológica possa ser considerada um aqüífero.

Parte significativa dos terrenos emersos da Terra é formada por rochas de permeabilidade primária muito baixa, como as rochas cristalinas. Neste tipo de rocha o sistema aqüífero ocorre de duas formas, como tipo poroso no manto de intemperismo e como tipo fraturado na rocha sã em maiores profundidades. $\mathrm{Na}$ literatura internacional os aqüíferos em meios cristalinos fraturados vêm sendo chamados de "fractured-bedrock aquifer", "fractured aquifer", "fractured rocks aquifer", "hardrocks aquifer" e "bedrocks aquifer". No Brasil, os aqüíferos que ocorrem em meios cristalinos fraturados foram denominados de aqüíferos fraturados, aqüíferos fissurais ou aqüíferos cristalinos (Manuel Filho 1996, Costa 1986).

Neste capítulo são apresentadas as principais aplicações e a importância do estudo dos aqüíferos fraturados, como o uso em estudos de caráter ambiental, geotécnicos e principalmente para extração de água subterrânea para abastecimento público, uso industrial e agropecuário. O trabalho também 
apresenta descrições sobre as formas de ocorrência do aqüífero, características hidráulicas, e variações de propriedades hidráulicas (porosidade, condutividade hidráulica, capacidade de armazenar etc.).

\subsection{Importância e aplicação dos estudos em aqüíferos fraturados}

Antes de se discutir propriamente a importância e aplicação dos estudos em aqüíferos fraturados, é preciso observar as áreas potenciais de ocorrência destes aqüíferos, que são locais onde são encontradas rochas muito consolidadas e de baixa permeabilidade primária (sedimentares, metamórficas, ígneas ou vulcânicas). Tais rochas cobrem uma área relativamente grande das regiões emersas do globo. No Brasil aproximadamente metade do território é constituído de rochas de permeabilidade primária baixa.

Entender o fluxo da água subterrânea em meios consolidados fraturados tem sido importante em diversos segmentos de estudo, com destaque para as áreas de geologia ambiental, geologia de engenharia, exploração de água subterrânea e petróleo. No caso da geologia de engenharia destaca-se a aplicação na abertura de túneis, desenvolvimento de minas, estabilização de encostas, construções de fundações, e, principalmente, construções de grandes barragens. No suporte destas atividades geotécnicas, freqüentemente é necessário um estudo do fluxo da água subterrânea mediante a estimativa de permeabilidade conduzida na própria localidade (in situ).

O fluxo de águas subterrânea através de fraturas apresenta grande importância na área de recursos hídricos. Em rochas de permeabilidade primária baixa, o fluxo ocorre através de estruturas, responsáveis pela chamada permeabilidade secundária. Portanto, ao perfurar um poço em meio consolidado de baixa permeabilidade primária, torna-se de suma importância que a perfuração intercepte o maior número de estruturas com capacidade de armazenar e transmitir água. Quando poços não interceptam tais estruturas, eles apresentam produtividade muito baixa, tornando sua utilização economicamente inviável. Por este motivo, anualmente são abandonados milhares de poços de produção (Meiser \& Earl Hidrogeologists 1982). 
Mais recentemente, a preocupação com questões ambientais levou a descoberta de contaminações em meios consolidados fraturados, e os conseqüentes estudos para delimitação e remediação da contaminação têm exigido diversas novas técnicas de investigação que são diferentes das que eram previamente usadas em estudos geotécnicos e exploração de petróleo. Neste caso, o foco concentra-se na caracterização das propriedades de transporte em fraturas altamente permeáveis em matriz de rocha com ou sem permeabilidade primária.

Nos estudos de caráter ambiental a preocupação é a proteção dos aqüíferos de uma eventual fonte (resíduos industriais, aterros sanitários, lixo atômico, produtos químicos, combustíveis etc.). Quando já constatada a contaminação, o objetivo torna-se precisar a chegada destes contaminantes até os receptores nas áreas de descarga, como corpos de água superficial, ou em poços de extração de água subterrânea para consumo. Neste caso, os estudos em aqüíferos fraturados devem ter como maior interesse as regiões fraturadas de alta permeabilidade da formação, pois nestas ocorrem os caminhos preferenciais para o transporte dos contaminantes.

Para os estudos de transporte de compostos no aqüífero fraturado a principal propriedade da formação é o fluxo da água subterrânea, cujos fatores principais são o caminho da água até o receptor e a velocidade da água subterrânea no meio. O caminho depende de diversos fatores, como atitude das fraturas individuais na rede de fraturas, gradiente hidráulico, e topografia do terreno. Quanto à velocidade, ela influencia em propriedades de dispersão e advecção no transporte.

A velocidade da água subterrânea no aqüífero define fatores como o tempo de trânsito do contaminante através do aqüífero, e tem como variáveis a condutividade hidráulica, o gradiente hidráulico e a porosidade efetiva. No caso de fluxos por fraturas, a condutividade hidráulica depende da geometria e abertura das fraturas individuais da rede de fraturas, segundo a lei cúbica (Snow 1969). 
Em muitos casos, investigações da água subterrânea são requeridas para o desenvolvimento de modelos numéricos que são usados para simular sistemas de fluxo. Nestes casos os modelos são aplicados às mais diversas tarefas, como simulação de transporte de contaminantes pela água subterrânea, rebaixamento de aqüíferos para realização de obras (minas, fundações, túneis etc.), estimativa de área de influência de poços de captação de água e, mais recentemente, em estudos de vulnerabilidade de aqüíferos.

Entretanto, pelo fato do fluxo da água subterrânea ser primariamente regido pelas fraturas em escala local, os métodos matemáticos tradicionais contínuos apresentam uma aproximação pobre. Quando as escalas são maiores, em nível regional, ou em áreas em que a densidade de fraturas é muito alta, o fluxo da água subterrânea pode ser definido por métodos contínuos aplicados a meios fraturados. Freqüentemente o arranjo das fraturas é heterogêneo e complexo, causando dificuldades na sua representação nos modelos. Existem modelos e técnicas de modelagem que podem ser usadas para circundar este problema, incluindo o uso de estocástica ou uma mistura de técnicas estocásticasdeteminísticas (Smith \& Schwartz 1984).

O estudo hidrogeológico em rocha fraturada também é importante para estimativas de quantidades de fluidos em fontes geotermais naturais, compreensão de reservatórios de gás e petróleo, e ainda em construções de túneis e cavidades subterrâneas para estocar resíduos, água, óleo, gás e outros fluidos.

\subsection{Características gerais dos aqüíferos cristalinos fraturados}

Uma das principais características do aqüífero fraturado é o fato da água subterrânea ser armazenada e transmitida através das fraturas da rocha, uma vez que a matriz da rocha apresenta permeabilidade primária muito baixa. Esta característica confere aos aqüíferos deste tipo uma heterogeneidade e anisotropia muito relevante. Ao estudar os aqüíferos é necessário definir o volume elementar representativo, ou de acordo com a literatura internacional representative elementary volume (REV), termo que significa o mínimo volume de rocha que 
deve ser considerado para se estudar o meio poroso ou fraturado de maneira representativa.

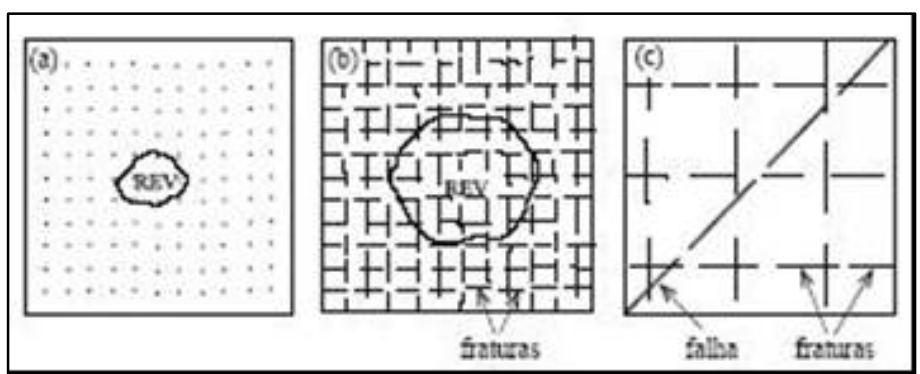

Figura 3.1 - Volume elementar representativo (REV): a) meio poroso homogêneo; b) meio fraturado homogêneo em meio contínuo e; c) meio fraturado heterogêneo, em meio descontínuo que não apresenta REV (Singhal \& Gupta 1999).

Ao estudar um aqüífero o objetivo é atribuir ao REV propriedades hidráulicas como porosidade, condutividade hidráulica e coeficiente de armazenamento, abordagem esta conhecida como estudo de meio contínuo. Quanto maior a anisotropia e a heterogeneidade maior será o REV, porque para representar as características deve-se aumentar a população amostrada. Neste caso a abordagem é dita descontínua, e os estudos devem considerar o fluxo em fraturas de maneira individual.

Quando a rocha apresenta uma anisotropia e/ou heterogeneidade muito grande (como uma zona de cisalhamento) o aqüífero pode até não apresentar REV. Neste caso não é valido atribuir a um aqüífero valor para suas características hidráulicas. No contexto de um estudo realizado em aqüífero fraturado isso passa a exigir uma discretização dos atributos, muitas vezes inviável economicamente.

A abordagem do meio contínuo, para fluxos laminares e lineares, permite a aplicação da "lei de Darcy" e, neste caso, pode ser aplicada a "lei cúbica" (Snow 1969) para definir a condutividade hidráulica, segundo a equação 3.1. 


$$
K=\frac{\rho g N b^{3}}{12 \mu}
$$

Onde:

$\mathrm{K}=$ condutividade hidráulica $\mu=$ viscosidade da água $\mathrm{g}=$ aceleração da gravidade $\rho=$ densidade da água

$\mathrm{N}=$ fraturas por metro

$\mathrm{b}=$ abertura da fratur

Para aplicar a lei cúbica é necessário o conhecimento do aqüífero, como a densidade de fraturas do meio e um entendimento tal que permita atribuir um REV ao estudo. Também é necessário um estudo das fraturas individualmente ou por grupos, com intuito de permitir uma caracterização da abertura média das fraturas do maciço.

A abertura das fraturas assume papel mais importante do que a densidade de fraturas propriamente dita, uma vez que o fator cúbico da abertura representa variação significativa quando comparado à variação linear da densidade de fraturas, conforme a ilustração abaixo.

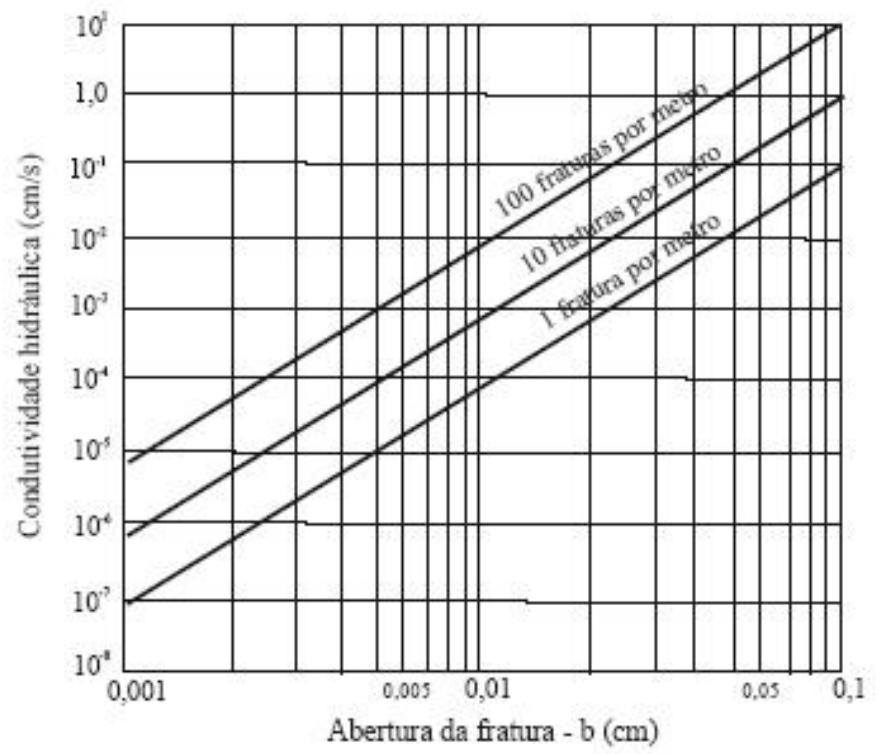

Figura 3.2 - Influência da abertura e da densidade de fraturas na estimativa da condutividade hidráulica em meios fraturados (Hoek \& Bray 1981). 
Quando o REV não pode ser definido, o maciço deve ser abordado como um meio descontínuo, e o estudo passa a ter como foco a análise individual das fraturas. Neste caso, Novakowski (1995) definiu que a transmissividade de um meio pode ser definida com base em um poço que atravessa um número de fraturas, onde é possível estimar a somatória das suas aberturas conforme a equação:

$$
T=\frac{\rho g(2 b)^{3}}{12 \mu}
$$

Onde:

$T=$ Transmissividade

$\mu=$ viscosidade da água

$\mathrm{g}=$ aceleração da gravidade

$$
\begin{aligned}
& \rho=\text { densidade da água } \\
& b=\text { somatória das aberturas das fraturas }
\end{aligned}
$$

A abertura das fraturas influencia também no tipo de fluxo no aqüífero. Quando a abertura é muito grande o fluxo pode deixar de ser linear e tornar-se turbulento. Neste caso a lei de Darcy deixa de ser válida para o aqüífero, mas a lei cúbica continua válida, quando o efeito da pressão de fluidos não for importante (Domenico \& Schwarz 1990).

Quando um aqüífero esta sendo bombeado ele pode apresentar dois tipos de fluxo, radial ou linear. Quando ocorre uma fratura de condutividade hidráulica muito maior que a da matriz ou do REV (quando ocorrem fraturas), o fluxo deixa de ser radial e passa a ser linear.

O modelo conceitual de fluxo radial que aparece comumente em textos de hidrogeologia, apresenta cones de rebaixamento ao redor de um poço bombeado, no qual as linhas de fluxo convergem radialmente para o poço, com linhas equipotenciais concêntricas ao poço bombeado, e o rebaixamento decresce com a distância do poço. Quando ocorre uma anisotropia este cone se deforma, alongando-se na direção de maior condutividade hidráulica $(K)$.

O modelo conceitual de um sistema de fluxo linear para um aqüífero homogêneo ocorre quando uma fratura de alta permeabilidade atravessa um poço. Quando o poço é bombeado o nível da água na fratura decai, induzindo um fluxo 
do aqüífero para a fratura. Desta maneira, a fratura aberta é uma superfície planar, que se torna uma extensão do próprio poço. Esta superfície hidraulicamente conectada é chamada de extensão do poço. Nesta configuração as linhas de fluxo são perpendiculares à fratura e as linhas equipotenciais são paralelas à extensão do poço, o que forma uma "calha" de rebaixamento ao invés de um cone de rebaixamento.
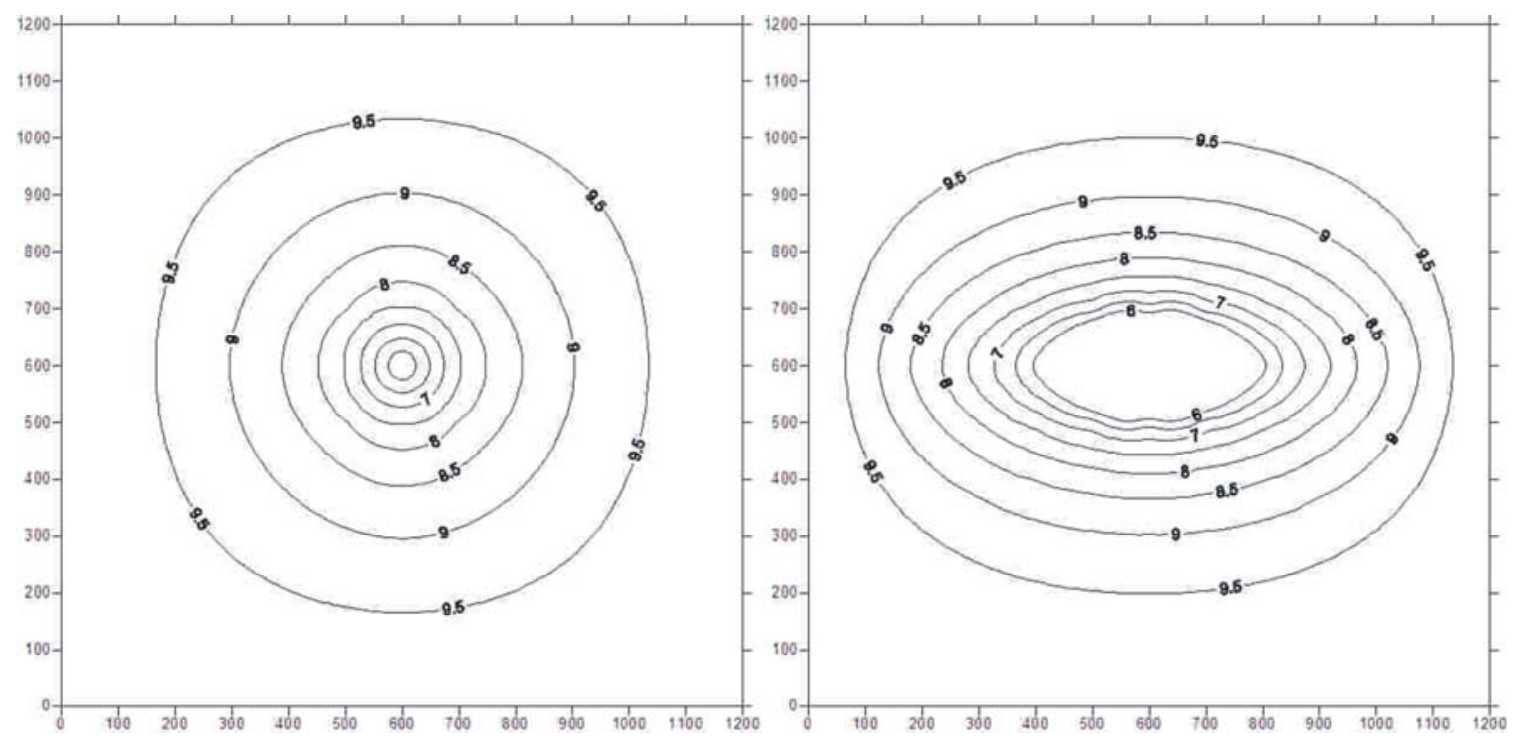

Figura 3.3 - O mapa potenciométrico da esquerda não apresenta anisotropia $(K x=K y)$, o mapa da direita apresenta uma anisotropia de 5 vezes $(\mathrm{Kx}=5 \mathrm{x} \mathrm{Ky})$.

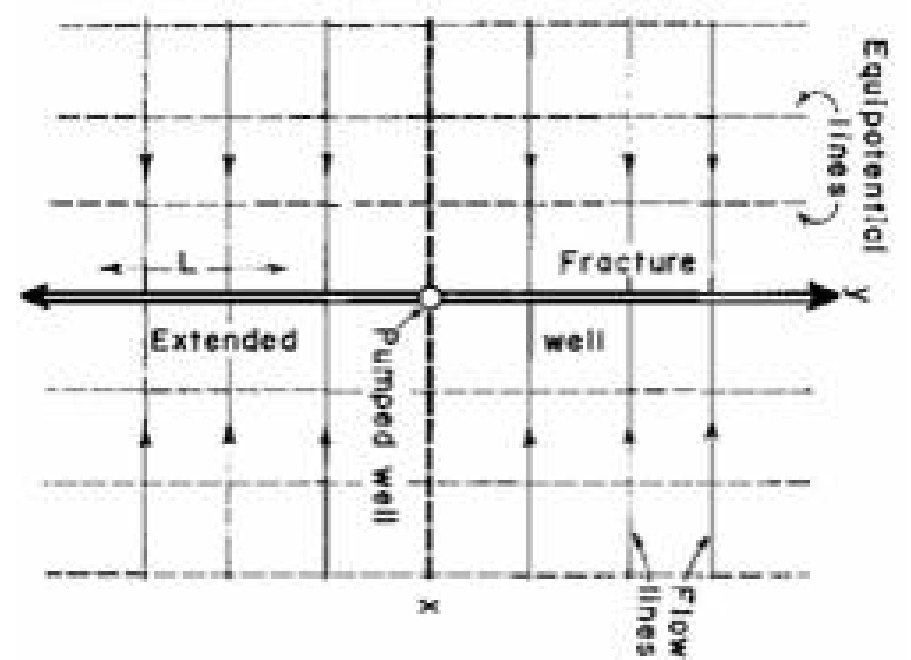

Figura 3.5 - Simplificação de fluxo em sistema linear (extraído de Jenkins \& Prentice, 1982). 
Enquanto a "lei cúbica" considera a abertura de uma fratura lisa planar como principal responsável pela condutividade hidráulica do aqüífero, a distribuição destas fraturas (tipicamente log-normal), é que dita a produtividade de um poço, uma vez que normalmente apenas uma ou duas destas fraturas são responsáveis pela produtividade de água do poço. 


\section{GEOLOGIA DA ÁREA ESTUDADA}

A área de estudo de semi-detalhe está localizada na parte leste do Município de Cotia, Estado de São Paulo, entre as latitudes 7.393.350 e 7.385.400 sul e longitudes 303.990 e 311.280 oeste, zona 23K. Com aproximadamente 58 $\mathrm{km}^{2}$ de área, ela se insere no contexto das rochas proterozóicas do Complexo Embu, na porção central da Faixa Ribeira, que inclui rochas intensamente deformadas devido a proximidade de grandes zonas de cisalhamento (figura $4.1 \mathrm{e}$ Anexo I, figura 2).

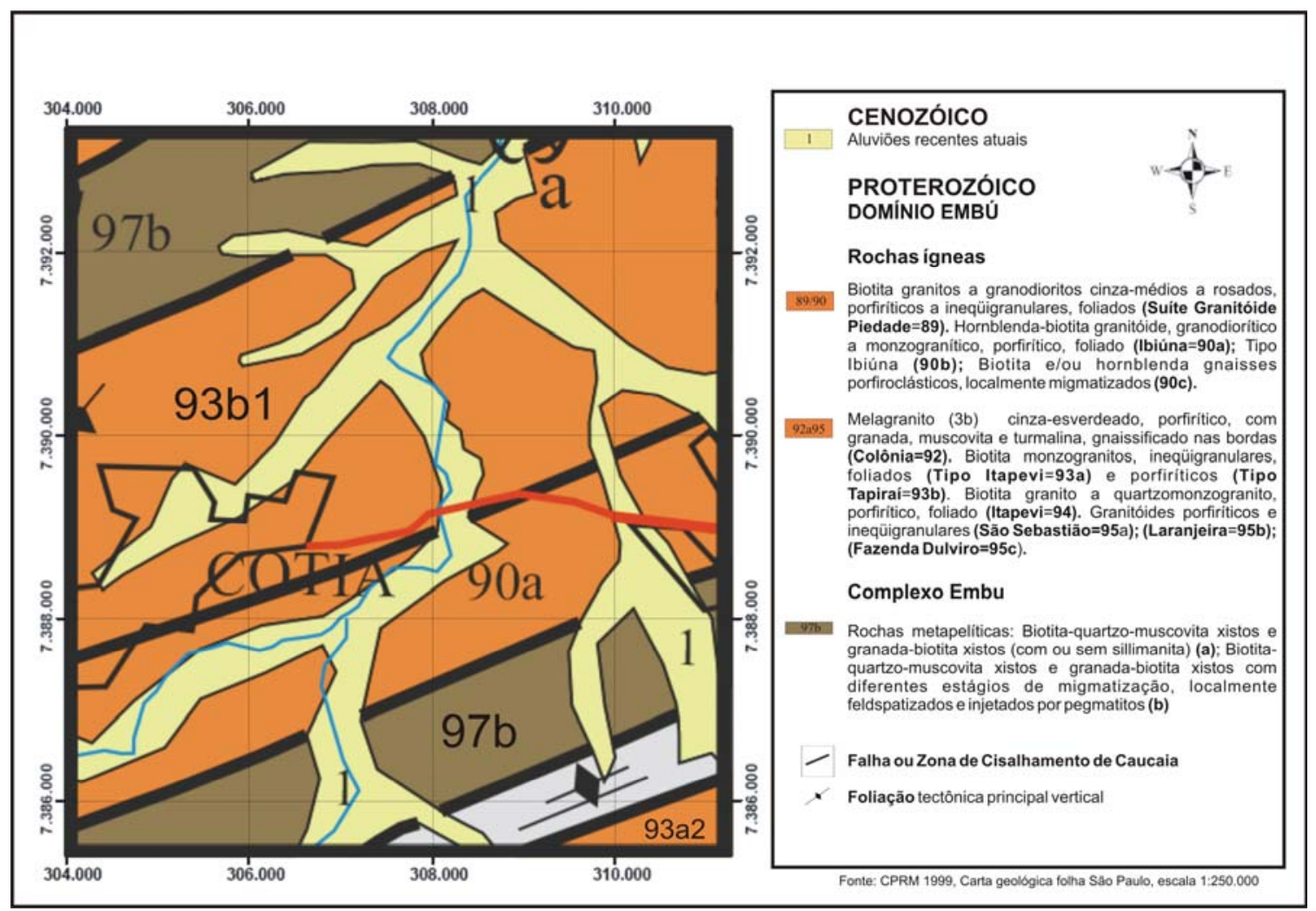

Figura 4.1 - Mapa geológico da área de estudo de semi-detalhe, modificado folha São Paulo, escala 1:250.000 (CPRM 1999).

A Faixa Ribeira integra uma rede continua de faixas móveis geradas entre 700 e $450 \mathrm{Ma}$, durante a amalgamação do Supercontinente Gondwana, e o principal período de atividade orogênica ocorreu entre 670 e $480 \mathrm{Ma}$ (Cordani et al. 2000). Ela se estende na direção aproximada NE-SW por cerca de $1400 \mathrm{~km}$ ao longo da costa do Brasil, limita-se ao norte com a Faixa Araçuaí, de direção 
predominante NNE, e ao sul com uma pequena área cratônica, o Terreno Luís Alves.

O Complexo Embu na porção sul-oriental do Estado de São Paulo foi originalmente descrito por Hasui (1975), incluído no Grupo Açungui (Hasui \& Sadowski 1976), posteriormente renomeado de Domínio Embu (Janasi \& Ulbrich 1985).

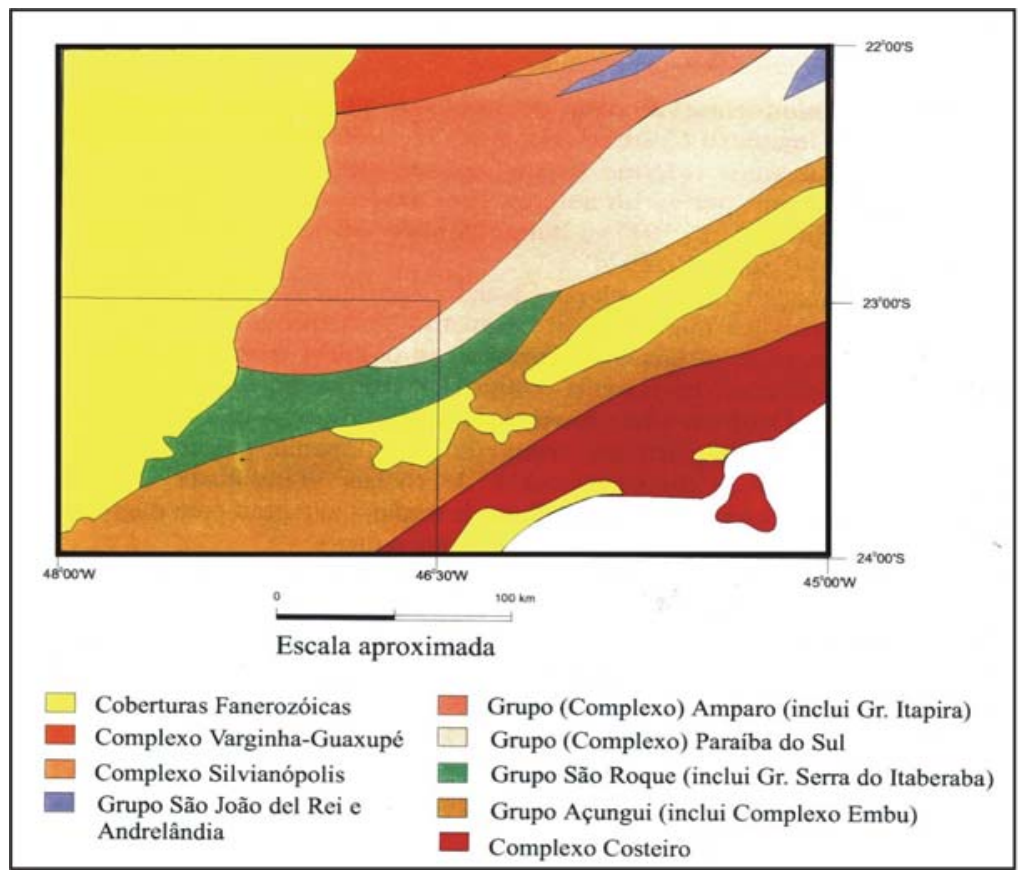

Figura 4.2 - Unidades litoestratigráficas do sudeste do Estado de São Paulo (CPRM 1999).

\subsection{Contexto geológico do Bloco Cotia}

Em termos litológicos, o Domínio Embu é constituído predominantemente por rochas supracrustais metamorfisadas em grau variável. Trabalhos realizados na região a oeste da Cidade de São Paulo na década de 70 (Hasui 1973, Hasui \& Sadowski 1976) distinguiram duas associações litológicas que foram denominadas Complexo Ectinítico Pilar do Sul, formado por rochas metassedimentares de baixo grau metamórfico, e Complexo Migmatítico Embu, formado por xistos e gnaisses migmatíticos. Trabalhos posteriores reconheceram a extensão de rochas equivalentes na região do Vale do Paraíba, onde foram também identificados núcleos de embasamento de idade Paleoproterozóica (e.g. Fernandes 1991). 
$\mathrm{Na}$ porção sudeste do Estado de São Paulo, o Complexo Embu compreende micaxisto, paragnaisse parcialmente migmatizado, quartzito (Complexo Embu), e xisto fino, filito e subordinadamente quartzito, metabasito e rocha calciossilicática (Seqüência Miracatu).

Hasui et al. (1969) e Hasui (1975) compartimentaram a área do mapeamento da Folha São Roque em blocos. Ao sul da Zona de Cisalhamento de Taxaquara foram considerados os Blocos Cotia e Juquitiba, que juntos formam o Conjunto Paranapiacaba (Hasui 1975). A área de estudo insere-se no Bloco Cotia, em contexto de rochas essencialmente magmáticas e migmatíticas.

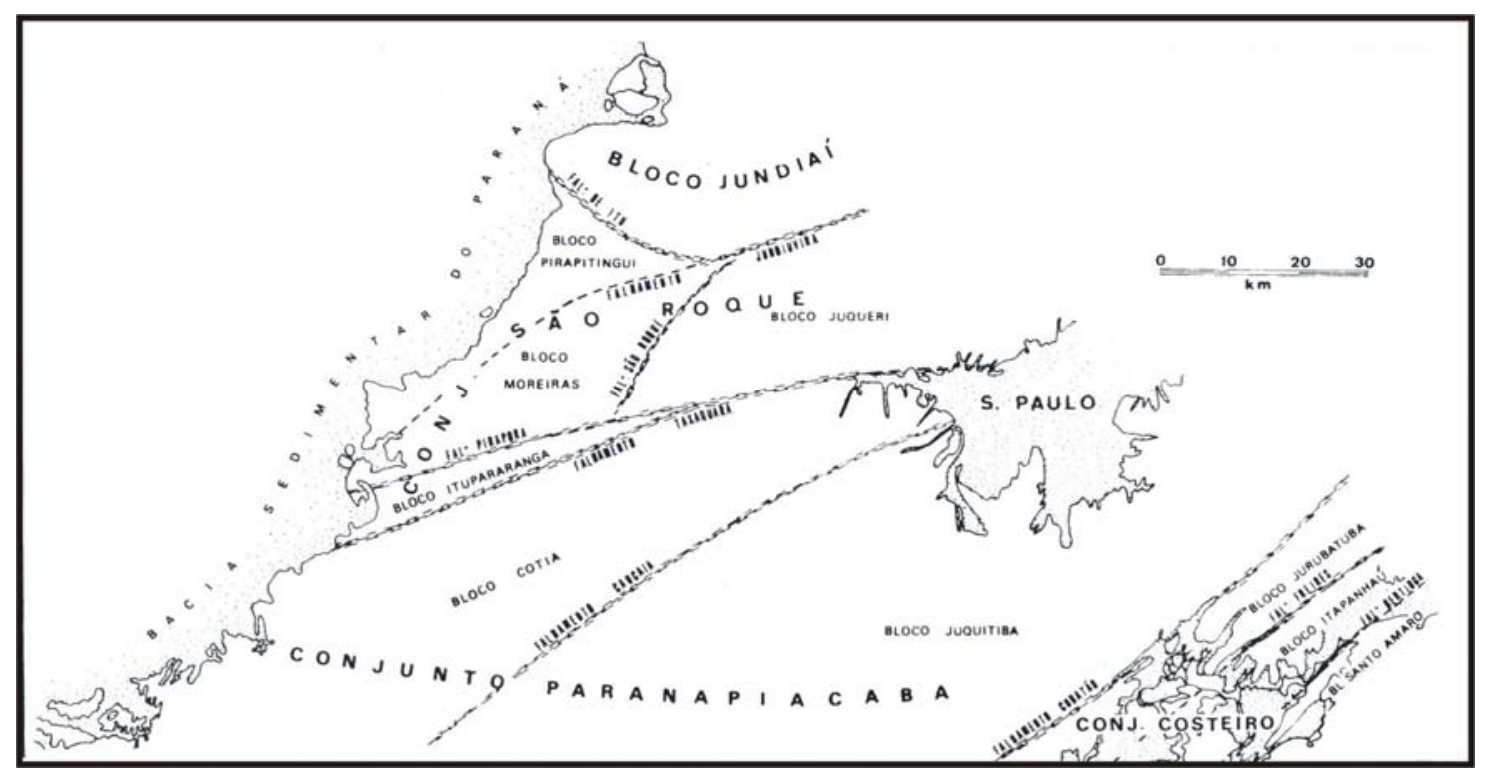

Figura 4.3 - Compartimentação tectônica das rochas pré-cambrianas do sudeste do Estado de São Paulo, mostrando o Bloco Cotia (Hasui \& Sadowski 1976).

Os granitóides do Bloco Cotia são do tipo tardi-tectônicos, e compõem dois corpos principais, designados de Batólito de Ibiúna e Maciço do Turvo (Hasui 1975). O Batólito Ibiúna é constituído pelo chamado granito Pirituba, nome genérico atribuído a rochas granitóides de três tipos texturalmente diversos sob o ponto de vista macroscópico: as porfiroblásticas, as inequigranulares e as finas.

As rochas porfiroblásticas têm megacristais róseo e/ou cinza claro, com dimensões variadas, podendo atingir até $3 \times 8 \mathrm{~cm}$, quando apresenta forma 
chamativa em rochas com superfícies sãs e matacões, e foram popularmente chamadas de olho-de-sapo (Hasui 1975). Os megacristais são de microclínio pertítico ou oligoclásio, comumente são poiquiloblásticos, englobando grãos de quartzo, micas e feldspatos.

A matriz aparece com coloração cinza clara ou escura, com granulação fina ou media fina. Os minerais essenciais são quartzo, microclínio e oligoclásio, que compõem uma textura hipidiomórfica granular. Os principais minerais acessórios são biotita, hornblenda, titanita, zircão, epidoto, opacos, apatita, carbonato e moscovita.

Coutinho (1972), mapeando a porção sul da Cidade de São Paulo, caracterizou isógradas de biotita, de almandina, de estaurolita e de sillimanita, além de ocorrência isolada de andaluzita, relacionada a metamorfismo de contato. No mesmo trabalho o autor definiu um evento de metamorfismo regional em condições de fácies xisto verde e anfibolito, um evento de contato e um evento retrógrado, e ainda foi proposto um evento metassomático.

Segundo Hasui (1975) as estruturas visíveis nos metamorfitos do Conjunto São Roque e no paleossoma dos migmatitos estromatíticos são de tipos diversos. As dobras observáveis em campo são centimétricas a decamétricas, isoclinais ou cerradas, com planos axiais sub-verticais, formadas pela estratificação e xistosidade no Complexo Embu. Hasui (1973) considerou que no Conjunto Embu as rochas estariam já deformadas em dobras isoclinais recumbentes ao sofrerem o dobramento do tipo coaxial.

Crenulação e transposição em maior ou menor grau foram observadas nos metapelitos e migmatitos, introduzindo ondulações adicionais que são visíveis em escala microscópica e de afloramento. A rotação das estruturas planares pode culminar com o aparecimento de nova xistosidade.

Hasui (1975) descreve ainda a ocorrência de juntas em quatro ou cinco sistemas bem desenvolvidos: i) um sistema verticalizado sub-transversal à xistosidade; ii) dois sistemas sub-verticais e oblíquos à xistosidade; a obliqüidade varia, situando-se em torno de $50^{\circ}$; iii) um ou dois sistemas sub-horizontais 
(menos de $40^{\circ}$ de inclinação). Normalmente um deles é observado nos afloramentos e faz pensar à primeira vista em alívio de carga como causa do sistema, mas quando aparecem os dois, mostram-se inclinados opostamente e têm relação com o mesmo regime de esforços causador dos anteriores. Nos maciços granitóides esses mesmos sistemas de juntas estão presentes, e a mesma qualificação é válida, mas em relação à foliação.

Falhas transcorrentes constituem as estruturas mais notáveis da região (Hasui 1975). Estas falhas foram tão intensas que geraram metamorfismo cataclástico e uma foliação conspícua, conferindo às rochas um caráter filonítico.

\subsection{Contexto tectônico e estrutural rúptil}

A evolução tectônica do Sudeste do Brasil é bastante complexa, resultado da superposição de esforços tectônicos desde o Pré-Cambriano até o Cenozóico. Neste contexto são apresentados os principais eventos tectônicos da região, compreendendo as grandes Zonas de Cisalhamento dextrais, a abertura do Oceano Atlântico, e a formação do Rift Continental do Sudeste do Brasil e seus principais eventos de deformação. Os dois últimos eventos apresentaram caráter rúptil.

\subsubsection{Zonas de Cisalhamento Taxaquara e Caucaia}

A Zona de Cisalhamento Taxaquara foi investigada em maior detalhe por Hennies et al. (1967) e a de Caucaia detalhada por Hasui (1973). Estas zonas de cisalhamento apresentam faixas cataclásticas mais ou menos espessas, com larguras de 1500 metros e até maiores, incluindo protomilonitos a ultramilonitos, às vezes com quartzo e mica recristalizados. Estes milonitos são caracterizados pela presença marcante de foliação cataclástica geralmente sub-vertical, com lineações de baixo ângulo.

A Z.C. de Caucaia apresenta direção NE-SW, tem início aparentemente a $\mathrm{NE}$, sob os sedimentos da Bacia de São Paulo, e desaparece a SW junto à extremidade do corpo granitóide do Maciço Ibiúna. 
A Z.C. Taxaquara apresenta rejeitos superiores a $165 \mathrm{~km}$ (Hennies et al. 1967), enquanto que na Z.C. Caucaia o rejeito não pôde ser estimado. Os sentidos de deslocamento das zonas de cisalhamento não puderam ser determinados nos levantamentos de campo (Hennies et al. 1967, Hasui 1973). Os autores inferiram o sentido de deslocamento dos sistemas de falhamentos (Taxaquara, Pirapora e Caucaia) com base em relações angulares. Este movimento ocorreria como conseqüência de um regime de esforços com componente principal orientado segundo E-W, onde a Z.C. Taxaquara apresentaria um movimento dextral e as Z.C. Caucaia e Pirapora apresentariam movimento sinistral (ver figura 4.4). Já o mapa da Folha São Paulo (CPRM 1999) indica que as zonas de cisalhamento tiveram um deslocamento dextral.

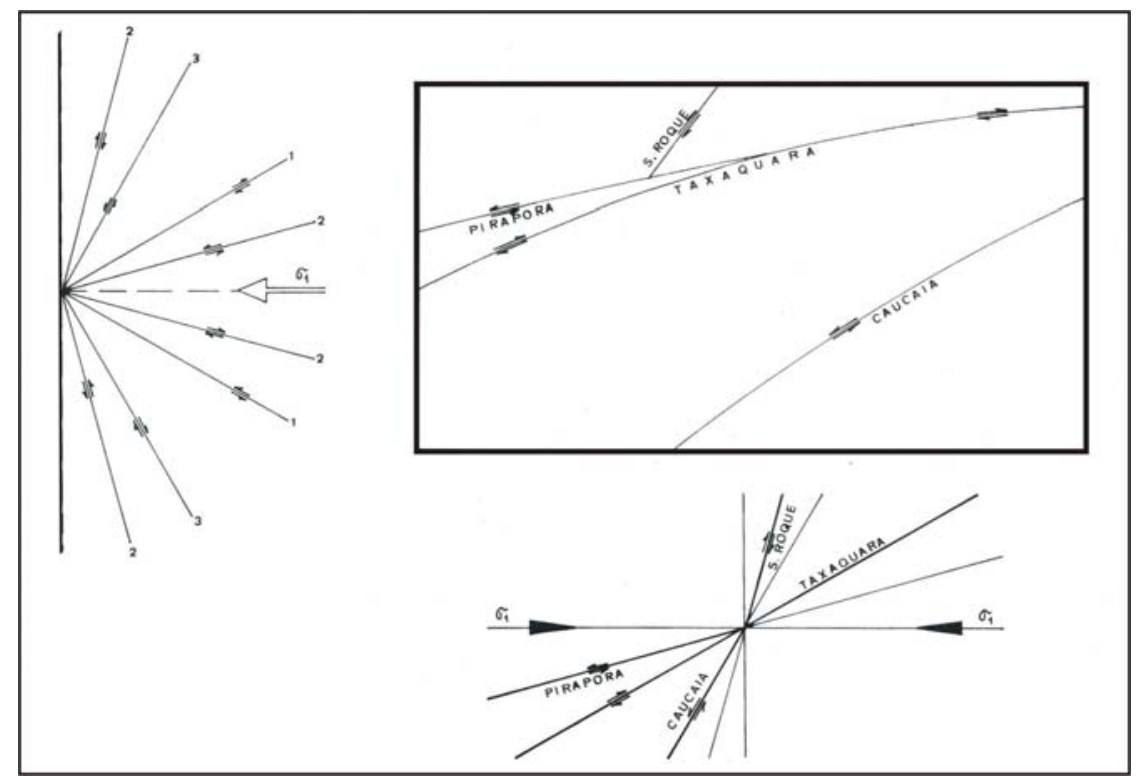

Figura 4.4 - Estimativa de sentido de movimento a partir de relações angulares (Hasui 1975).

Quanto à idade dessas falhas, Hasui \& Sadowski (1976) destacam que elas atingiram seqüências ectiníticas geradas no Ciclo Brasiliano, de modo que seriam posteriores ao metamorfismo regional. Também destacam que regionalmente essas falhas controlaram a intrusão de alguns maciços granitóides tarditectônicos, e ainda seccionaram alguns corpos granitóides pós-tectônicos. Tais evidências indicam que o sistema de falhas se relacionaria com a evolução do 
Ciclo Brasiliano, tendo começado a se desenvolver após o metamorfismo regional e se manifestado até após o magmatismo pós-tectônico, o que também indicaria atividade até a estabilização da plataforma.

\subsubsection{Abertura do Oceano Atlântico}

Após a formação das zonas de cisalhamento, que definem o arcabouço geológico estrutural regional, os eventos geológicos mais relevantes são aqueles vinculados à Reativação Wealdeniana (Almeida 1969), ou Reativação SulAtlantiana (Schobbenhaus et al. 1984). Tais fenômenos levaram à deformação e ruptura do Gondwana, ao desenvolvimento da margem continental passiva e à abertura do Oceano Atlântico.

A abertura do Oceano Atlântico ocorrido durante o Eocretáceo, que subdividiu o supercontinente Gondwana, reativou inúmeras descontinuidades mais antigas. Os movimentos em pulsos perduraram desde o Cretáceo até o Cenozóico. Segundo Almeida \& Carneiro (1998) as grandes falhas ligadas a esta abertura ocorreram onde hoje é a plataforma continental, restando à Falha de Santos o papel de principal estrutura ocidental da abertura do Oceano Atlântico. Desta maneira, a área de estudo provavelmente apresenta poucas estruturas que tiveram reativações de grande porte durante o evento. Entretanto, deve ser ressaltado que no início da abertura os esforços regionais eram distensionais, de direção NW-SE, o que teria favorecido a reativação distensional das antigas zonas de cisalhamento neoproterozóicas.

Concomitantemente à separação do Gondwana e à sedimentação da Bacia de Santos, ocorreu um soerguimento progressivo e pulsativo da área plataformal e continental vizinha à Bacia (Asmus e Guazelli 1981). Vignol-Lelarge et al. (1994) mostram que há $86 \mathrm{Ma}$, em uma área do embasamento cristalino da Serra do Mar sob influência do Arco de Ponta Grossa, houve um soerguimento acompanhado de erosão de $2,5 \mathrm{~km}$. Como conseqüência deste soerguimento, todo o conjunto de rochas pré-cambrianas foi submetido a um de alívio de carga, que originou um fraturamento de baixo ângulo nas rochas cristalinas do sudeste do Brasil (Almeida \& Carneiro 1998). 


\subsubsection{O Rift Continental do Sudeste do Brasil}

Segundo Riccomini (1989) o Rift Continental do Sudeste do Brasil (RCSB), de idade paleógena, é uma depressão alongada e deprimida com pouco mais de 900 km de comprimento, compreendida entre os estados do Paraná, São Paulo e Rio de Janeiro. O rift segue uma direção ENE-WSW, ao longo da linha de costa atual. Ele foi instalado no domínio da Faixa Ribeira, de idade neoproterozóica. Numerosos corpos de rochas alcalinas eocretáceas a paleogênicas ocorrem ao longo das bordas do rift. Zonas de cisalhamento neoproterozóicas de direção NE a E-W foram reativadas como falhas normais no Paleógeno e transcorrentes no Neógeno, e estas contribuíram para a instalação e deformação das bacias que compõem o RCSB.

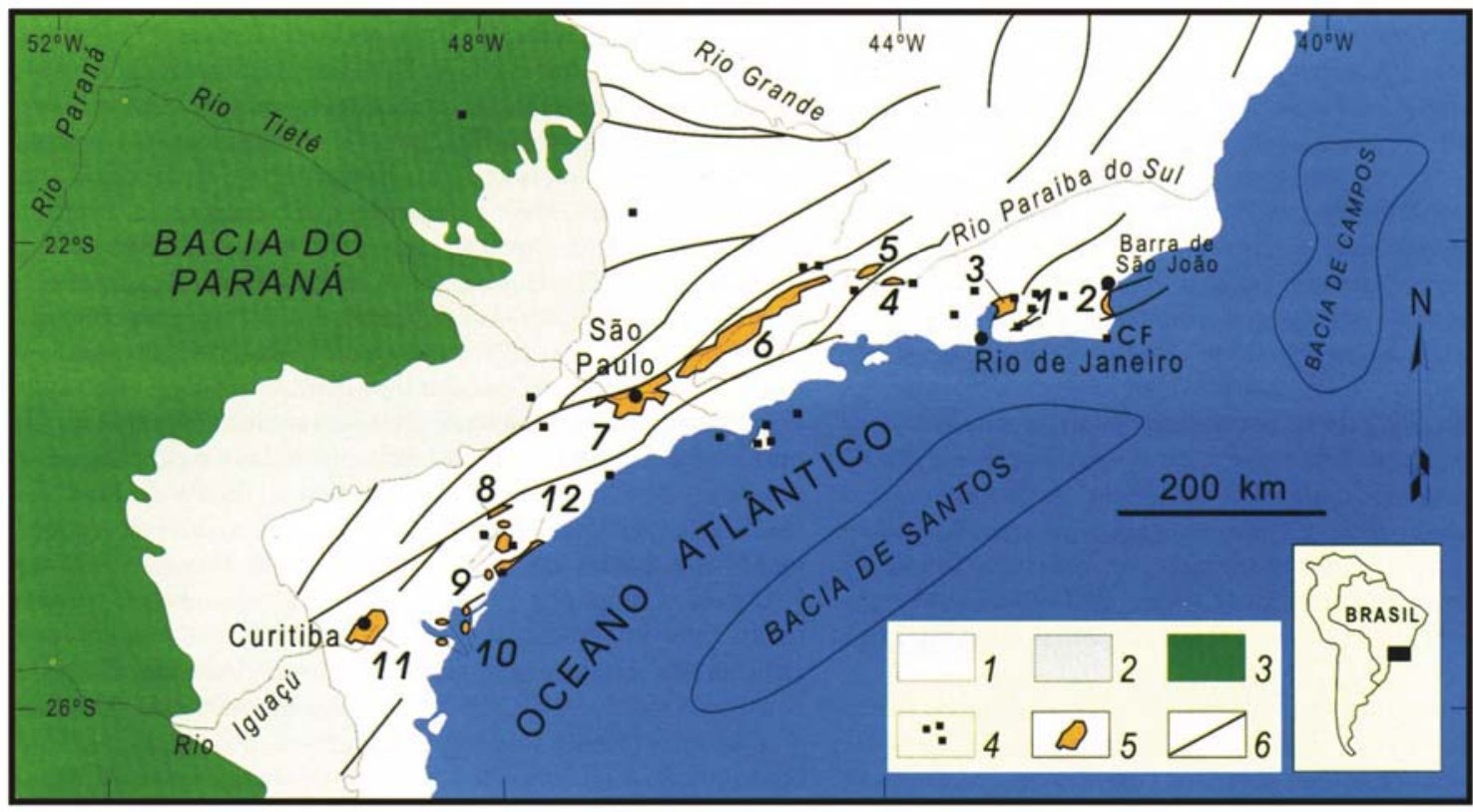

Figure 4.5 - Contexto geológico regional do Rift Continental do Sudeste do Brasil (RCSB) - 1) embasamento pré-cambriano; 2) rochas sedimentares paleozóicas da Bacia do Paraná; 3) rochas vulcânicas toleíticas eocretáceas da Formação Serra Geral; 4) rochas relacionadas ao magmatismo alcalino mesozóico-cenozóico; 5) bacias cenozóicas do rift (1- Bacia de Itaboraí, 2Gráben de Barra de São João, 3-Bacia do Macacu, 4-Bacia de Volta Redonda, 5- Bacia de Resende, 6- Bacia de Taubaté, 7- Bacia de São Paulo, 8-Gráben de Sete Barras, 9- Formação Pariquera-Açu, 10-Formação Alexandra e Gráben de Guaraqueçaba, 11- Bacia de Curitiba, 12Gráben de Cananéia); 6) zonas de cisalhamento pré-cambrianas, em parte reativadas durante 0 Mesozóico e Cenozóico. (Riccomini et al. 2004). 
O RCSB pode ser subdividido em três segmentos: ocidental, central e oriental. A área de estudo insere-se no segmento central, que acomodou as bacias de São Paulo, Taubaté, Resende e Volta Redonda. A deposição dos sedimentos no rift contou com depósitos proximais e distais de leques aluviais associados à planície aluvial de rios entrelaçados, depósitos em sistema lacustre e sistema fluvial meandrante oligocênico, manifestações vulcânicas e hidrotermais paleogênicas, e sedimentação neogênica.

As estruturas relacionadas ao tectonismo gerador e deformador do RCSB são importantes na área de estudo. As estruturas identificadas em afloramentos e sondagens podem ser correlacionadas àquelas atribuídas à geração e deformação do RCSB. Ao longo de todo o RCSB as deformações rúpteis podem ter sua idade relativa definida por meio de superposições de estruturas em rochas sedimentares que puderam ser datadas.

Em estudos realizados em rochas do substrato do RCSB foi reconhecida a atuação de um regime transcorrente sinistral, com encurtamento de direção NESW e distensão NW-SE, afetando corpos alcalinos neocretáceos cuja idade foi considerada neocretácea a paleocena (Riccomini 1995, Ferrari 2001). Desta maneira o regime transcorrente sinistral precederia um evento distensivo de direção NNW-SSE, responsável pela instalação das bacias, devido à ampla reativação de estruturas neoproterozóicas como falhas normais mestras com estrias ortogonais à direção das falhas das bordas de bacia (Riccomini et al. 2004).

As fases tectônicas deformadoras envolveriam novas reativações ao longo das falhas preexistentes, e em menor escala a geração de novas estruturas (Riccomini 1989, Riccomini et al. 2004). Os eventos deformacionais compreenderiam:

a) transcorrência sinistral de direção E-W, com distensão NW-SE, e localmente, compressão NE-SW, de idade neogênica (Mioceno?);

b) transcorrência dextral, com compressão NW-SE, de idade quaternária (Pleistoceno Superior); 
c) distensão de direção WNW-ESE e idade holocena;

d) compressão de direção E-W, holocena.

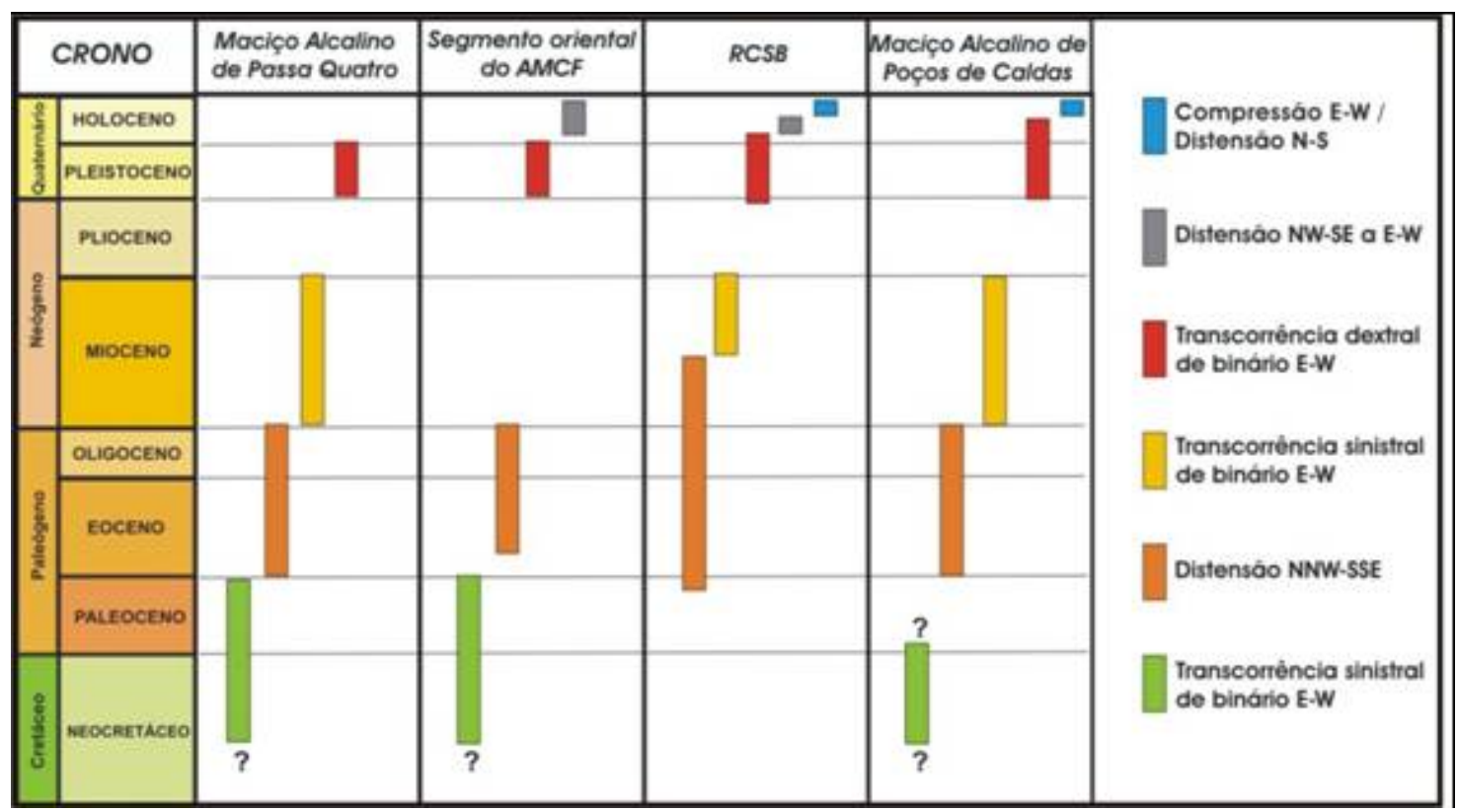

Figura 4.6 - Evolução tectônica do RCSB e arredores (Alves 2005).

Os três últimos eventos deformadores são neotectônicos. Eles foram bem caracterizados no segmento central do RCSB (Riccomini 1989, Salvador 1994, Salvador \& Riccomini 1995).

Fernandes da Silva (1998) em estudo da tectônica rúptil da região entre Pilar do Sul e Votorantim (oeste e noroeste da área de estudos), identificou as mesmas fases deformacionais do RCSB, com exceção do primeiro evento de compressão. O autor destaca o último evento como uma compressão $E-W$, com falhas inversas e transcorrentes dextrais orientadas predominantemente na direção NNE, variando em alguns locais para NNW e NE; também ocorrem juntas de distensão com direção aproximada E-W a WNW, além de juntas conjugadas de cisalhamento com direções ENE a NE e WNW a NW. 


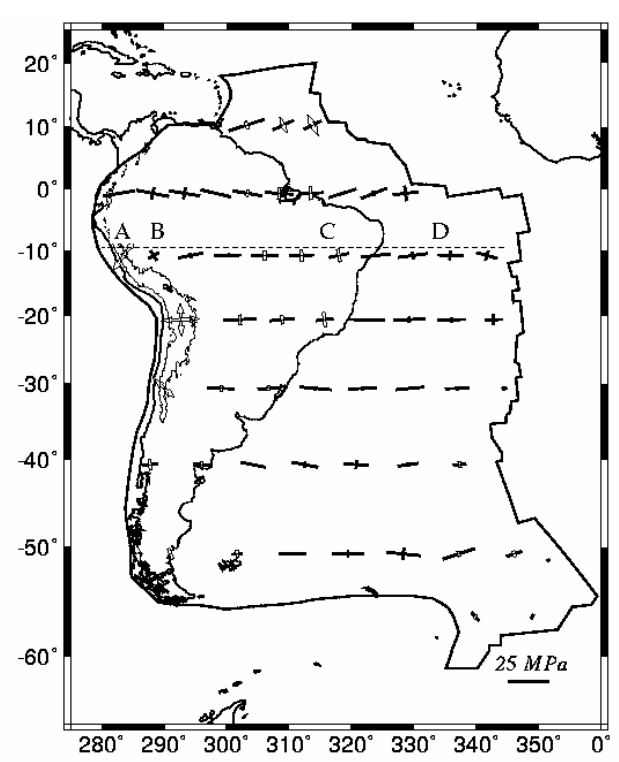

Figura 4.7 - Distribuição das tensões na placa Sul-Americana, segundo o modelo 3 de Coblentz e Richardson (1996).

Na região de Campinas, Fernandes (1997) identificou fases deformacionais rúpteis correlacionáveis ao RCSB e ao trabalho de Fernandes da Silva (1998). Entretanto, a última fase descrita pela autora não corresponde à última fase encontrada em outros trabalhos correlacionáveis ao contexto da área estudada (compressão E-W).

Neves et al. (2003) descreveram, na região de Jundiaí, falhas normais NWSE, falhas inversas NE-SW e falhas transcorrentes dextrais de direção E-W e NWSE, correspondentes a um contexto transcorrente dextral (binário orientado segundo $E-W)$, que se ajusta a um cenário neotectônico transtrativo, decorrente da migração da placa Sul Americana para oeste.

Não foram ainda realizados estudos específicos sobre a neotectônica da área de estudo. Entretanto, a julgar pela correlação verificada entre as estruturas das regiões de Campinas, Pilar do Sul-Votorantim e Jundiaí com aquelas do RCSB, espera-se que as estruturas rúpteis da região de Cotia tenham sido geradas ou reaproveitadas durante os mesmos eventos deformacionais regionais. 


\section{ANÁLISE DA TECTÔNICA RÚPTIL}

\subsection{Análise morfométrica}

\subsubsection{Mapa hipsométrico}

A figura 3 do Anexo I apresenta o mapa hipsométrico da área de estudo. Neste foram definidas 8 classes altimétricas com intervalos de 20 metros de variação.

As altitudes variam de 741 a 900 metros em relação ao nível do mar. As mais baixas altitudes representam a planície de alagamento do rio Cotia, com altitudes na classe de 741 a $780 \mathrm{~m}$. Nas áreas mais altas, na porção oeste da área, observam-se elevações de 860 a 900 metros dispostos na direção aproximada NNE-SSW.

O rio Cotia apresenta duas direções preferenciais. Ele corre no sentido sudoeste-nordeste, até a região central da área de estudos onde passa a fluir na de sul para norte, permanecendo com esta orientação até desembocar no Rio Tietê, aproximadamente $1 \mathrm{~km}$ ao norte. No segmento estudado, o rio apresenta apenas dois expressivos afluentes, ambos com planícies retilíneas com direções definidas segundo N-S, NE-SW e, na porção nordeste, com um afluente de direção NW-SE.

No mapa hipsométrico também é possível observar que as águas superficiais de toda a área são drenadas para o rio Cotia. Desta maneira é perfeitamente cabível atribuir ao rio o papel de nível de base e ponto de descarga dos aqüíferos da área.

\subsubsection{Extração de lineamentos morfoestruturais}

A utilização do mapa de lineamentos morfoestruturais, a partir de sombreamento de relevo (Anexo I - figura 4), evidencia direções predominantes, segundo NE-SW, N-S e, secundariamente NW-SE, conforme ilustradas nos diagramas de roseta (Anexo I, figura 4). 
Resultados similares apresentaram os lineamentos de fotogeologia (Anexo I, figura 5). Nesta ferramenta houve um predomínio dos lineamentos NE-SW em quase toda a área. Secundariamente, aparecem também as estruturas de direção N-S. As estruturas E-W se concentraram na porção centro-norte, e as estruturas NW-SE, de ocorrência mais limitada, aparecem discretamente em porções situadas nas partes norte e sul da área estudada.

Ambos os resultados apontaram para estruturas NE-SW e N-S como as mais importantes da área que correspondem às direções do curso do rio Cotia. Os dois mapas de lineamentos destacam ainda um grande lineamento de direção NW-SE na porção centro-sul, e outro E-W bem marcado na porção oeste da área.

\subsubsection{Mapa de orientação de vertentes e declividade}

O mapa de orientação de vertentes (Anexo I, figura 6) ressalta um padrão de lineamentos NE-SW, gerando predominantemente vertentes com mergulhos variando de NW a $\mathrm{N}$ e de SE a S. Essa tendência enfatiza os grandes lineamentos NE-SW da região central, oeste e norte da área. Vertentes orientadas para oeste e leste também são destacadas, principalmente na porção leste da área, assim como na parte centro-leste, onde o rio Cotia corre segundo a direção N-S. Concordando com os resultados das outras variáveis morfométricas (hipsométrico, lineamentos de sombreamento de relevo, superfícies de base, rugosidade do relevo e densidade de lineamentos e drenagens), a ocorrência de vertentes orientadas com mergulhos para NE e SW é muito localizada, o que reflete um baixo registro de lineamentos de direção NW-SE.

O mapa de declividades (Anexo I, figura 7) mostra que a área de estudo é marcada por declividades baixas, com valores menores do que $10^{\circ} \mathrm{em}$ sua região central e sul, e declividades pouco mais acentuadas nas regiões mais altas destacadas no mapa hipsométrico, atingindo no máximo $20^{\circ}$ de inclinação. As drenagens e as planícies do rio Cotia são bem destacadas neste mapa, assim como os lineamentos NE-SW, N-S e secundariamente NW-SE, enquanto que lineamentos E-W não podem ser observados. 
Os mapas de orientação de vertentes e de declividade, quando observados em conjunto, apresentam uma particularidade: as áreas de vertentes que mergulham para $\mathrm{N}$ e NW são maiores do que as que mergulham para S e SE. Estas áreas maiores apresentam menor declividade. Esta tendência aponta a ocorrência de declividades abruptas nas faces voltadas para sudeste e suaves nas faces para noroeste dos lineamentos NE-SW. O mesmo não é observado nos lineamentos N-S.

\subsubsection{Mapa de superfícies de base}

Segundo Golts \& Rosenthal (1993), os principais aspectos a serem observados em mapas de superfícies de base são: i) inflexões marcantes nas linhas de isobases, normalmente causadas por movimentações tectônicas ou mudanças bruscas de litotipos; ii) aproximação de linhas de isobases, comumente atribuídas a movimentações tectônicas; e iii) distanciamento das linhas de isobases, que é associado a um gradiente topográfico suave ou a uma região de subsidência localizada com entulhamento sedimentar.

Para a extração de lineamentos do mapa de superfícies de base (Anexo I, figura 9) foram observados os aspectos destacados por Golts \& Rosenthal (1993). No mapa também foram plotadas as estruturas geológicas medidas durante os levantamentos de campo. Para interpretação das anomalias observadas no mapa de superfícies de base foi elaborado um mapa de sombreamento de relevo das superfícies de base. A este mapa sombreado foi sobreposto um mapa geológico simplificado. Esta composição também foi utilizada para gerar perspectivas de diferentes ângulos de visada (Anexo I, figura 10).

Baseados na análise com as ferramentas supramencionadas, alguns lineamentos que não são completamente visíveis pelos critérios assinalados por Golts \& Rosenthal (1993) puderam ser traçados. Em contrapartida algumas anomalias de linhas de isobase não foram traçadas devido suas origens terem sido atribuídas a mudanças bruscas de litotipos (não consideradas para o modelo de tectônica rúptil). É importante ressaltar que foram traçados apenas lineamentos que apresentaram comprimentos próximos ao tamanho da área definida. Nem 
todos os lineamentos foram assinalados, mas todas as direções foram representadas.

Os grupos direcionais de lineamentos são apresentados por ordem de importância e relevância no relevo observado:

- lineamentos NE-SW, definidos por critérios de aproximação e paralelismo das linhas de isobase;

- lineamentos N-S, definidos por critérios de aproximação, paralelismo e inflexões de linhas de isobase;

- lineamentos E-W, assinalados principalmente por critérios de inflexões, e secundariamente de aproximação e paralelismo de linhas de base;

- lineamentos NW-SE, definidos por critérios de aproximação e paralelismo das linhas de isobase (este grupo direcional apresenta-se mais discreto na área, com exceção da porção nordeste da área, onde aparece bem marcado).

O mapa de superfícies de base mostra um equilíbrio entre as estruturas de direção N-S, NE-SW, NW-SE e E-W.

Ao observar o diagrama de rosáceas dos lineamentos (Anexo I, figura 9), verifica-se que as direções N-S e NE-SW predominam em relação as outras porque estes dois agrupamentos direcionais concentram-se em classes individuais (classes de $10^{\circ}$ ) enquanto os grupos direcionais NW-SE e E-W apresentaram-se dispersos em mais de uma classe.

A principal direção de lineamentos na área é NE-SW. Esta é também a direção das foliações e xistosidade regional, assim como dos eixos maiores dos corpos de rochas granitóides. Estes lineamentos NE-SW são bem evidentes em imagens e mapas morfométricos, e são truncados e deslocados por lineamentos de direções E-W e N-S.

Os lineamentos N-S apresentaram grande influência nas superfícies de base, em geral são extensos e aparecem em quase toda a área. Apresentam grande linearidade, mesmo quando cruzam lineamentos de outras direções 
exceção feita aos E-W, com os quais não apresentam nenhum tipo de relação de superposição.

Os lineamentos de direção E-W apresentam menor influência nas anomalias de superfícies de base e em geral concentram-se nas porções centrais, norte, leste e nordeste da área. Estes lineamentos cruzam trechos de distanciamento entre as linhas de isobases, que podem mostrar um entulhamento sedimentar. Estes trechos de distanciamento ocorrem principalmente nos locais onde estes lineamentos se cruzam com os demais grupos de lineamentos. Este grupo apresenta clara superposição sobre os lineamentos NW-SE e NE-SW, mas não corta nem é cortado pelos lineamentos N-S.

Os lineamentos de direção NW-SE são os menos marcados da área, e sua relação com estruturas tectônicas não é evidente. Isto pode se dever a:

- não haver estruturas de direção NW-SE com capacidade de influenciar no relevo da área; nesse caso não se tratariam de lineamentos mas sim meros alinhamentos sem controle estrutural;

- $\quad$ estes lineamentos são recentes demais para o método, influenciando muito pouco a formação das drenagens de segunda ordem, e deveriam apresentar melhor controle nas drenagens de primeira ordem; desta maneira deve ser observada forte influência no mapa de lineamentos extraídos de sombreamento de relevo (Anexo I, figura 4);

- estes lineamentos são influenciados por estruturas antigas que foram suprimidas no relevo por outras mais recentes.

As relações de corte entre os lineamentos sugerem que:

- os lineamentos de direção N-S e E-W, seriam conjugados, pois aparentemente estiveram ativos na mesma escala de tempo, nota-se que na área eles não se cruzam, e normalmente apresentam extremidades partindo de um mesmo ponto, formando desta maneira cantos de $90^{\circ}$ (quinas); 
- os lineamentos de direção NE-SW, apesar de serem os mais expressivos nas anomalias dos mapas, são claramente superpostos pelos lineamentos de direção N-S e E-W;

- lineamentos de direção NW-SE, sem muita expressão no mapa de superfícies de base, seriam os mais antigos.

\subsubsection{Mapas de densidade de lineamentos, densidade de drenagens e rugosidade do relevo}

Os resultados das análises estatísticas das variáveis dos parâmetros rugosidade de relevo, densidade de drenagem e densidade de lineamentos estão resumidos na tabela 5.1. No presente trabalho foram entendidos como valores anômalos os valores superiores ou inferiores a média somada ou subtraída do desvio padrão (Chiessi 2004). Estes valores anômalos indicaram áreas potenciais para ocorrência estruturas ou particularidades a serem abordadas.

\begin{tabular}{|l||c|c|c|c|c|c||}
\hline \hline Variáveis & Mínimo & Máximo & Média & $\begin{array}{c}\text { Desvio } \\
\text { padrão }\end{array}$ & $\begin{array}{c}\text { Anomalia } \\
\text { alta }\end{array}$ & $\begin{array}{c}\text { Anomalia } \\
\text { baixa }\end{array}$ \\
\hline $\begin{array}{l}\text { Densidade de } \\
\text { lineamentos }\end{array}$ & 0,0000 & 0,0059 & 0,0020 & 0,0013 & 0,0033 & 0,0007 \\
\hline $\begin{array}{l}\text { Densidade de } \\
\text { drenagens }\end{array}$ & 0,0007 & 0,0056 & 0,0026 & 0,0010 & 0,0036 & 0,0016 \\
\hline $\begin{array}{l}\text { Rugosidade do } \\
\text { relevo }\end{array}$ & 1,0000 & 1,0380 & 1,0054 & 0,0043 & 1,0097 & 1,0011 \\
\hline \hline
\end{tabular}

Tabela 5.1 - Tabela de dados estatísticos de variáveis morfométricas.

O mapa de densidade de lineamentos permite visualizar as principais direções morfoestruturais, que podem indicar zonas de movimentações tectônicas, além de delimitar blocos com padrões geomórficos distintos (Hiruma \& Riccomini 1999).

No presente trabalho, o mapa de densidade de lineamentos (Anexo I, figura 11) apresentou densidades que variam de 0 a 0,006 metros de fratura para cada metro quadrado $\left(\mathrm{m} / \mathrm{m}^{2}\right)$. É interessante notar a distribuição linear das curvas de 
maior densidade de lineamentos, destacando-se as direções NE-SW, NW-SE e, secundariamente, $\mathrm{N}-\mathrm{S}$.

O mapa de densidade de drenagens permite a observação de anomalias entre blocos com comportamento distinto das drenagens, que podem refletir controle tectônico (Horton 1945). Jianjun et al. (1997) propuseram que: i) regiões onde a taxa de deposição é maior do que a taxa de subsidência apresentam alta densidade linear de drenagens; ii) áreas em franco soerguimento são caracterizadas pela diminuição da densidade linear de drenagens; e iii) áreas em fase final de soerguimento (nas quais a intensidade do soerguimento é igual ou mais baixa do que a incisão dos canais) apresentam um aumento na densidade linear de drenagens.

O mapa de densidade de drenagens (Anexo I, figura 12) apresenta concentrações de drenagens somente ao longo das áreas de menor altitude da área. Em linhas gerais, o mapa de densidade de drenagens mostra tendências lineares, coerentes com drenagens de terceira e quarta ordem.

O mapa de rugosidade do relevo (Anexo I, figura 13) apresenta valores mais elevados (até $1,038 \mathrm{~m}^{2} / \mathrm{m}^{2}$ ) em setores das partes noroeste e sudeste da área. Valores baixos a médios (entre 1,000 e 1,005) foram observados nas planícies de inundação e imediações das grandes drenagens da área, principalmente ao longo do rio Cotia. As anomalias do mapa delineiam alinhamentos segundo NE-SW, N-S e, secundariamente, NW-SE.

\subsection{Análise estrutural}

Durante os levantamentos de campo foram estudados 30 afloramentos, dos quais 23 apresentaram estruturas planares reconhecíveis. A localização dos afloramentos estudados e comparação com os dados de lineamentos interpretados por morfometria são apresentadas no Anexo I, figura 14.

Em geral as rochas estão alteradas. Predominam granitóides foliados, mas também foram observados metassedimentos, gnaisses e milonitos. 
Os dados obtidos para as foliações são apresentados no estereograma a da figura 5.1, e mostram atitude média N047/42NW.

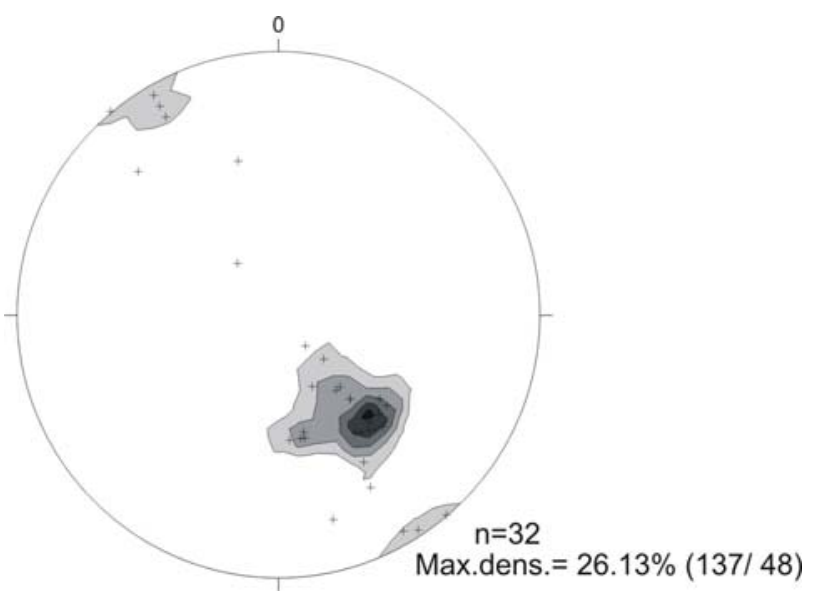

Figura 5.1 - Estereograma com a projeção dos pólos das foliações observadas.

As fraturas foram separadas em falhas com estrias e juntas. Devido à escassez de estruturas, não foi possível realizar estudos estatísticos de juntas por locais de coleta de dados. Foi efetuada a análise do conjunto de juntas, somado às relações geométricas observadas em afloramento, com o intuito de se definir as principais famílias, e após a correlação dos dados de campo com as estruturas oriundas de BHTV nas áreas de detalhe, atribuir características das famílias de estruturas provenientes do campo às estruturas observadas nos poços por meio de BHTV.

\subsubsection{Falhas}

Apenas cinco dados pareados de falhas e respectivas estrias (figura 5.2) foram obtidos, sendo quatro destes nos poucos afloramentos em rocha sã (locais 1 e 16). Estes dados foram analisados pelo método dos diedros retos.

Na figura 5.3 estão apresentados os dados de falhas, estrias e diagramas resultantes da aplicação do método dos diedros retos. Nos diagramas é possível observar basicamente dois padrões de paleoesforços. O primeiro e predominante (observado nos três afloramentos), é um encurtamento de direção NW-SE a NNW- 
SSE, com distensão de direção NE-SW a ENE-WSW. O segundo foi deduzido a partir de uma falha inversa do local P-16, que mostra uma compressão de direção NE-SW a NW-SE e distensão vertical.

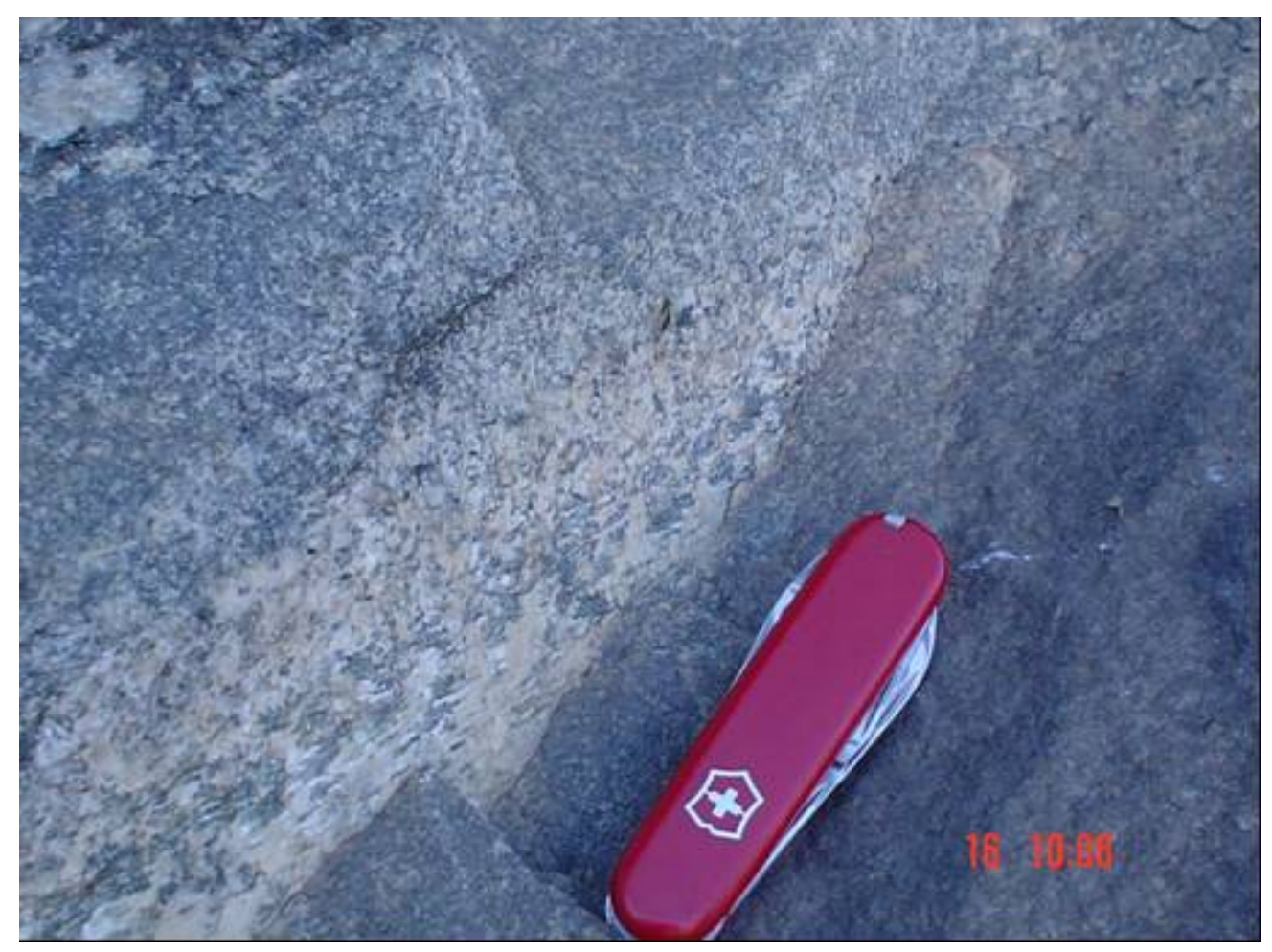

Figura 5.2 - Foto de plano de falha estriado, local P-01. 


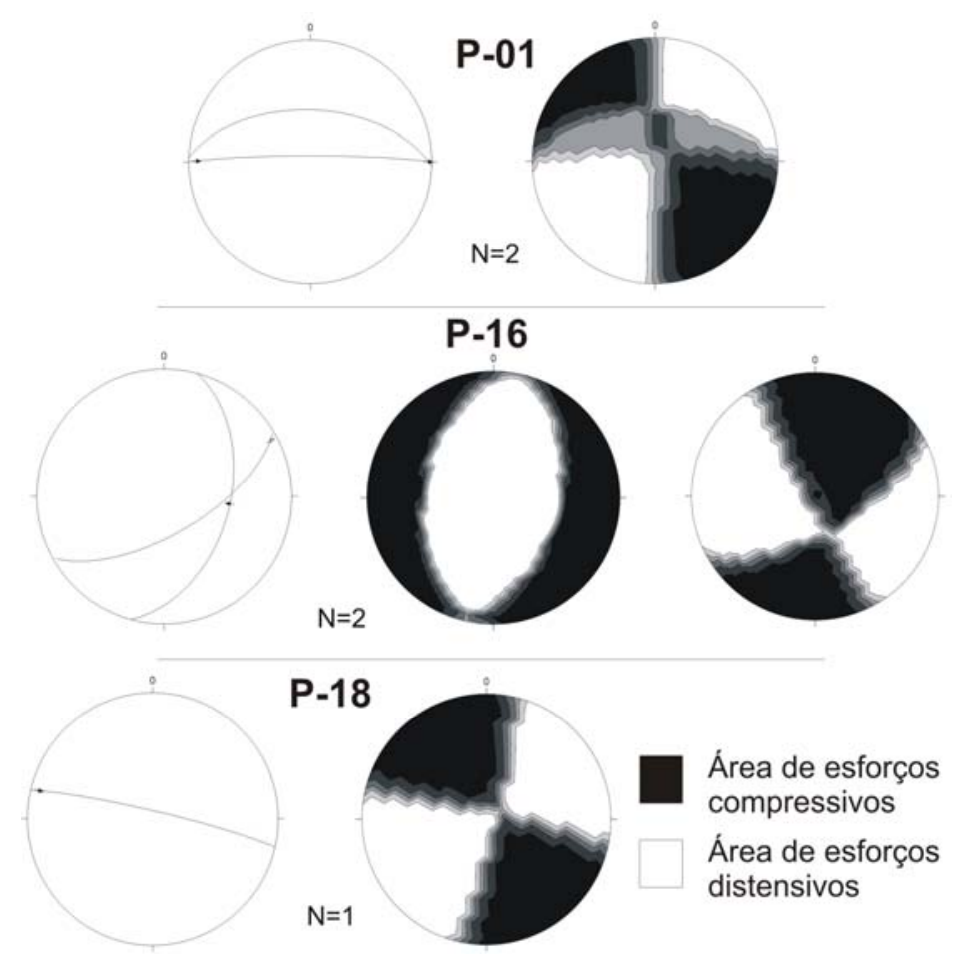

Figura 5.3 - Projeção estereográfica dos dados pareados de falhas e estrias e diagramas dos diedros retos referentes aos diferentes locais de coleta.

$\mathrm{Na}$ figura 5.4 estão representados os dados de falhas compatíveis com paleoesforço compressivo NNW-SSE e distensivos ENE-WSW.

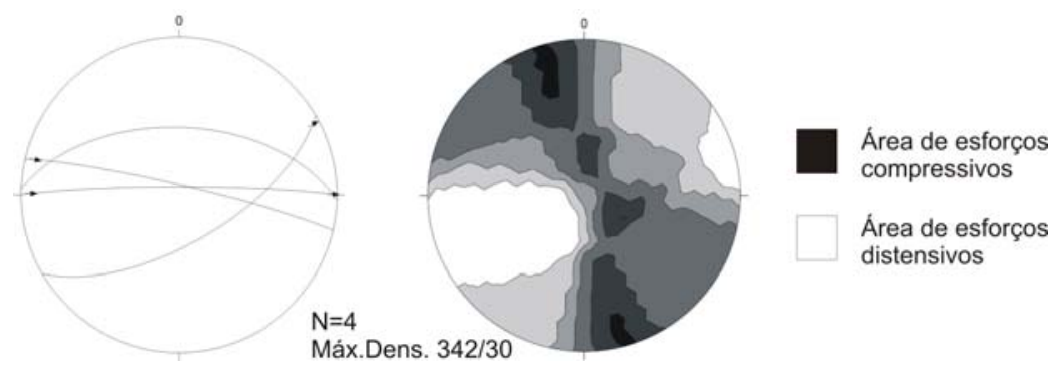

Figura 5.4 - Diagrama dos diedros retos para as falhas e estrias geradas sob mesmo campo de esforços. 


\subsubsection{Juntas}

As juntas medidas foram separadas em seis famílias de acordo com suas atitudes. A figura 5.5 apresenta as seguintes famílias (da mais freqüente para a menos freqüente): a) família NNW-SSE (plano médio N150/84NE); b) família NESW com alto ângulo de mergulho (plano médio N030/90); c) família E-W (plano médio N080/72NW); d) família WNW-ESE (plano médio N116/84NE); e) família NE-SW com mergulho médio para NW (plano médio N048/60NW); e f) família NESW com mergulho médio para SE (plano médio N056/42SE). Todas as famílias são do tipo híbrida (ângulo $2 \theta$ entre 10 e $50^{\circ}$ ).
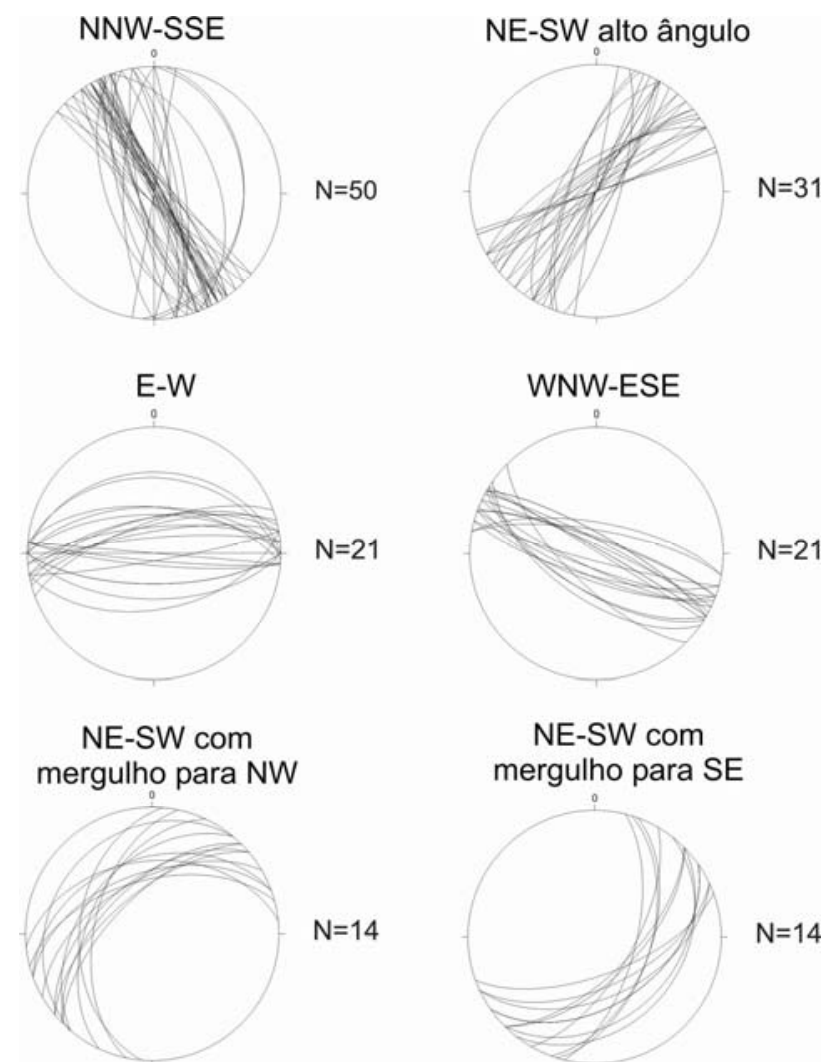

NE-SW com mergulho para SE

Figura 5.5 - Famílias de juntas reconhecidas em afloramentos da área estudada.

Nos locais P-2, 13, 16 e 24 foram reconhecidas juntas conjugadas (figura 5.6). No local P-16 ocorrem três conjuntos de estruturas conjugadas, tratadas separadamente $(P-16, A$ a $C)$. Os estereogramas com estes dados são 
apresentados na figura 5.7. Todos estes conjuntos foram tratados como populações de juntas, para se determinar os esforços horizontais máximo e mínimo (SHmáx e Shmín). Apesar de terem sido obtidos poucos dados, verifica-se boa correlação entre as estruturas conjugadas e as famílias de juntas (figura 5.5).

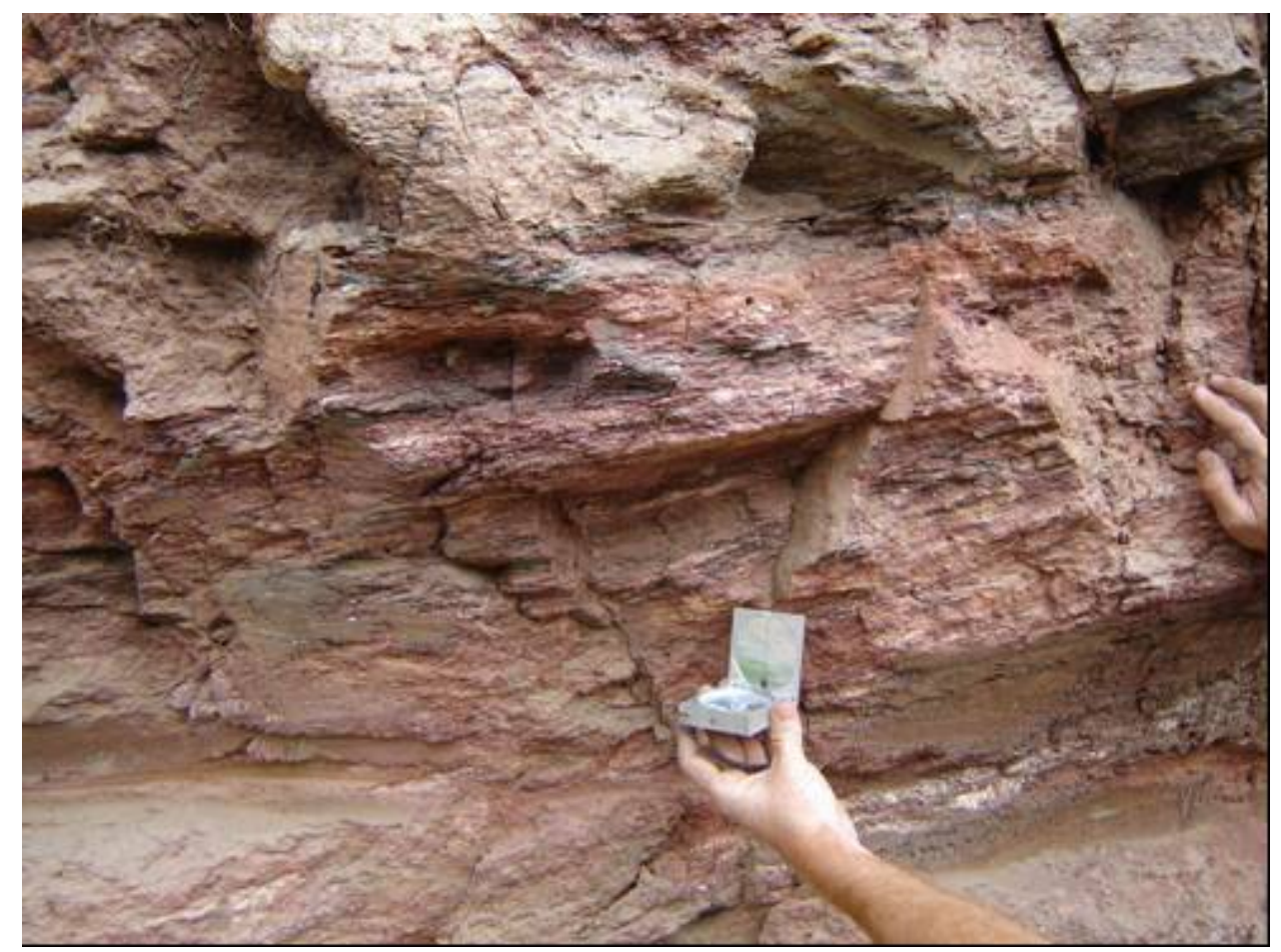

Figura 5.6 - Juntas conjugadas de direção NW-SE, local P-24.

As juntas do local P-02 apresentam padrão de cisalhamento com ângulo $2 \theta$ maior do que $50^{\circ}$, enquanto o local P-24 o padrão é híbrido com ângulo $2 \theta$ entre 10 e $50^{\circ}$. Nos locais P-02 e 24 foram obtidos direções de SHmáx NW-SE e Shmín NE-SW. Esta configuração se assemelha com as direções de encurtamento e distensão observadas nas falhas.

Nos locais P-13 e P16 as juntas são de cisalhamento, com exceção do local P-16C, com juntas do tipo híbridas. Estas estruturas indicam SHmáx de direção NE-SW e Shmín NW-SE. 

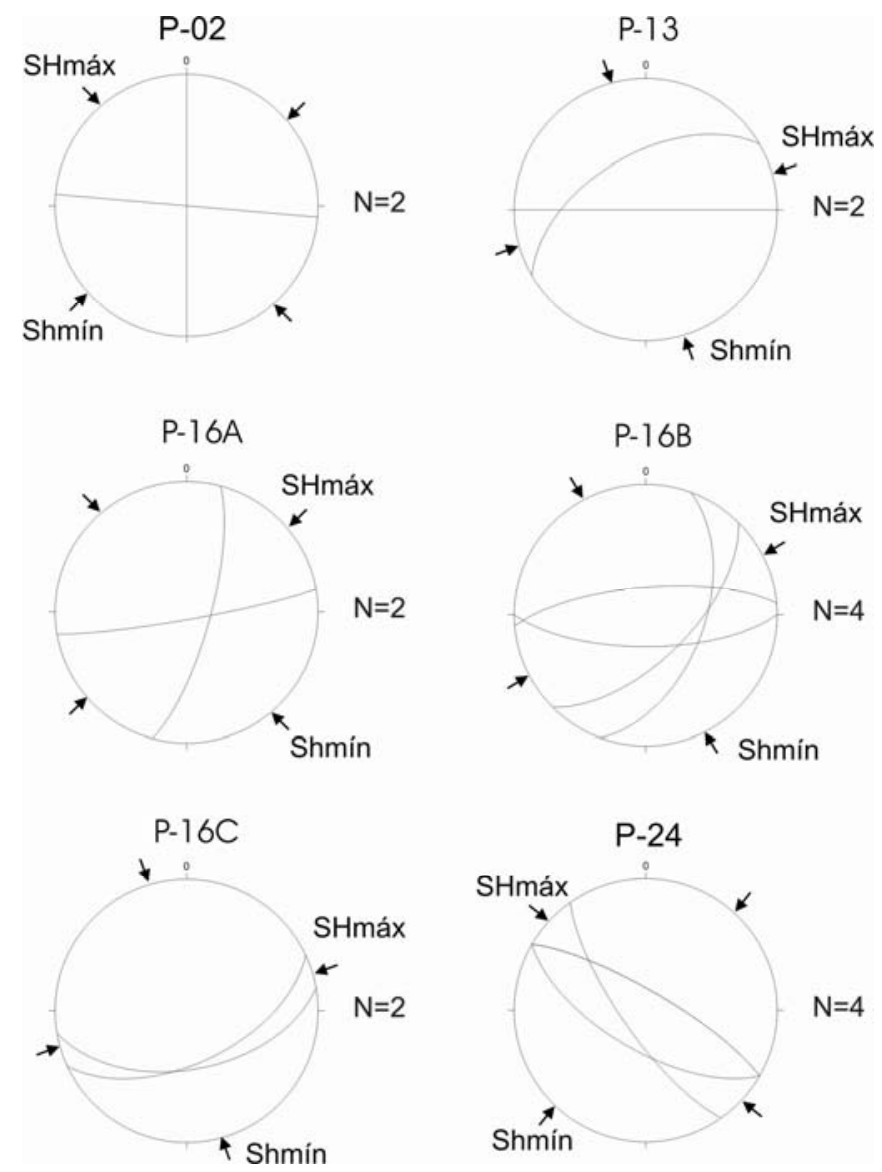

Figura 5.7 - Estereogramas das juntas conjugadas divididas por locais com as direções de SHmáx e Shmín.

\subsection{Cronologia da deformação rúptil}

A comparação das atitudes das juntas conjugadas com as famílias de juntas definidas sugere que as estruturas das famílias NNW-SSE e WNW-ESE podem ter sido geradas sob o mesmo campo de esforços compressivo de direção NW-SE. Esta mesma direção foi também obtida a partir dos dados de falhas. Regionalmente, este campo de esforços pode estar relacionado à transcorrência dextral com binário E-W, ocorrida durante o Pleistoceno Superior a Holoceno, como uma das fases de deformações rúpteis do Rift Continental do Sudeste do Brasil (Riccomini 1989).

As juntas de cisalhamento das famílias de direção NE-SW e E-W podem ter sido originadas sob um campo de esforços compressivo NE-SW, talvez 
relacionado à transcorrência sinistral com binário $\mathrm{E}-\mathrm{W}$, ativa regionalmente por duas vezes durante o Neocretáceo e o Neógeno (Riccomini et al. 2004).

Várias juntas da família NE-SW foram identificadas no local P-16C. Estas estruturas possivelmente foram geradas sob esforços distensivos de direção NWSE. No quadro tectônico regional proposto para o RCSB, este evento distensivo tem sido referido ao Paleógeno (Riccomini et al. 2004).

As juntas da família NNW-SSE são muito proeminentes. Quando observadas em rocha sã apresentam superfícies de continuidade lateral métricas (figura 5.8).

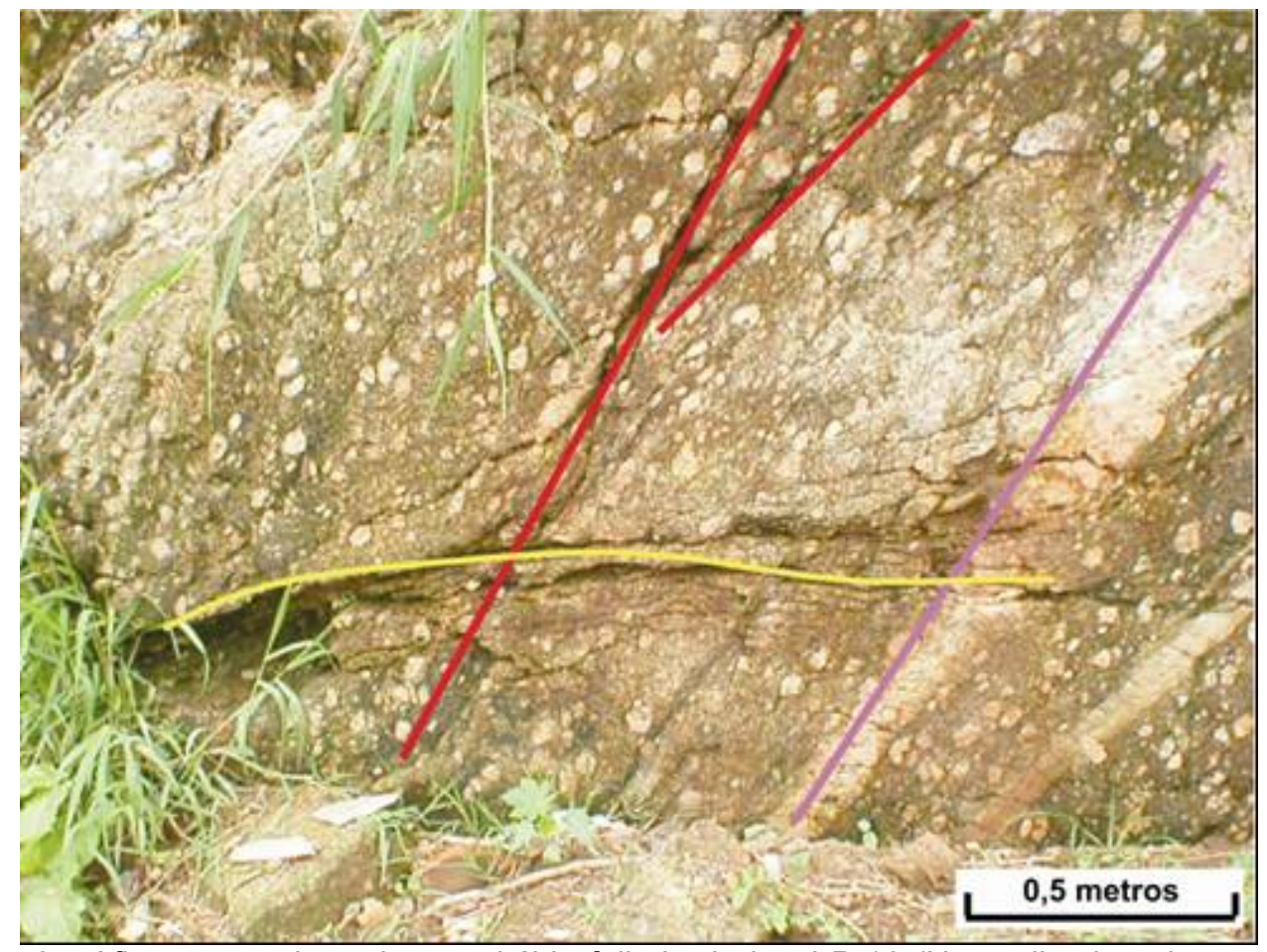

Figura 5.8 - Afloramento de rocha granitóide foliada do local P-16 (Norte direcionado para o lado esquerdo). As fraturas de mergulho médio (em vermelho, família direcional NE-SW) são subparalelas à foliação e aos veios de quartzo (em roxo). As fraturas de ângulo baixo (em amarelo, estrutura sub-horizontal) são menos contínuas e constituem superfícies irregulares, representando prováveis juntas de alívio. A seção frontal do afloramento é controlada por fraturas sub-verticais da família de direção NNW-SSE.

As juntas da família E-W são sub-verticais e parecem estar controladas por descontinuidades preexistentes relacionadas às grandes zonas de cisalhamento que afetaram o Bloco Cotia, como as de Caucaia do Alto e Taxaquara (figura 5.9). 
A orientação E-W desta família de juntas indica a vigência de esforços distensivos de direção N-S em sua geração, o que, no RCSB, compreenderia ao último evento rúptil de idade holocena.

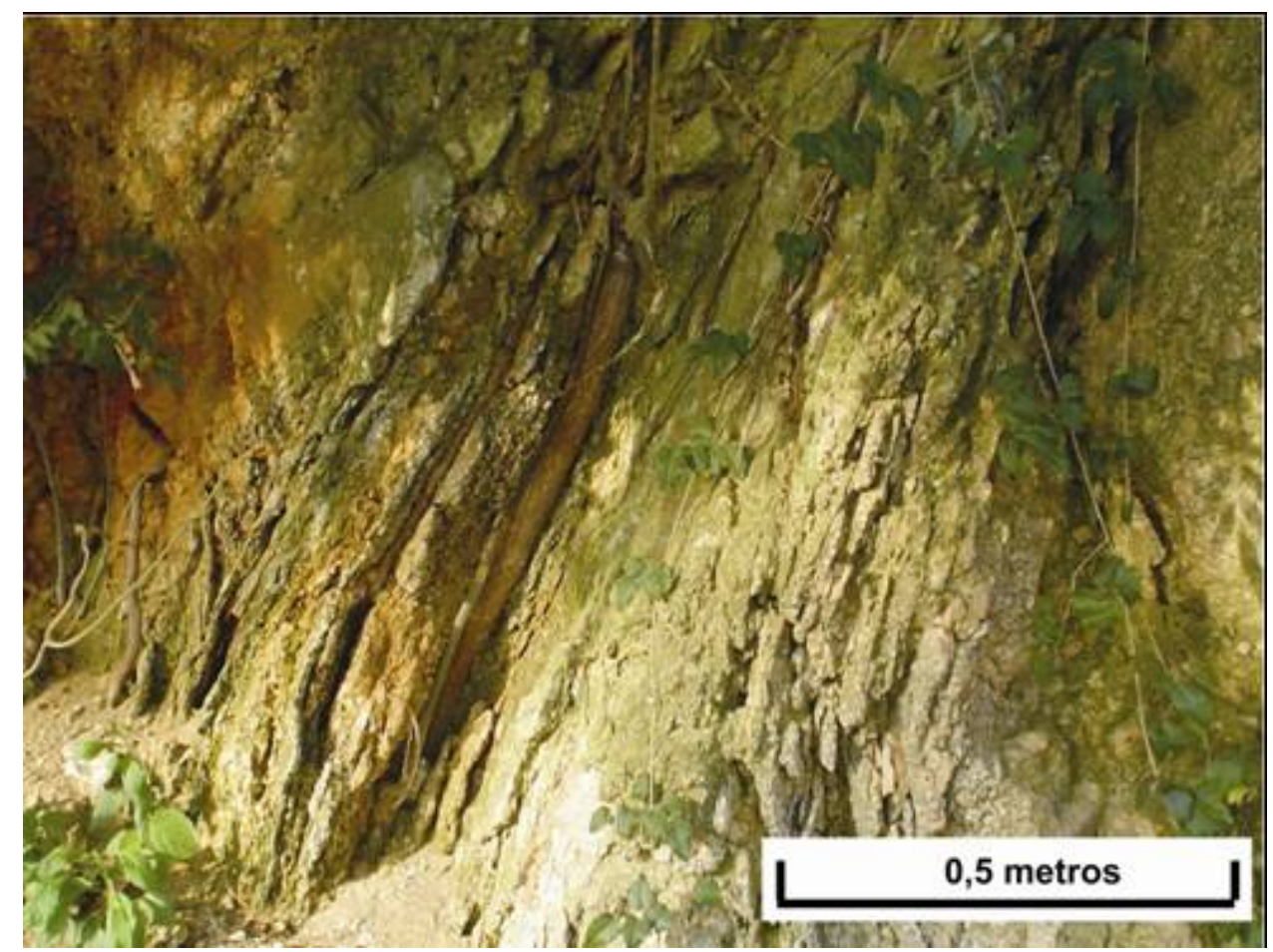

Figura 5.9 - Zona de cisalhamento de direção E-W em granitóide foliado, com o desenvolvimento de juntas sub-paralelas à foliação cataclástica, local P-16. 


\section{ESTUDO DAS ÁREAS DE DETALHE}

\subsection{Seções de resistividade elétrica}

As seções de resistividade elétrica foram executadas somente na área de detalhe $A$. Os resultados das seções de resistividade elétrica realizadas nesta área de detalhe A (Anexo I, figura 15) permitiram identificar diversas anomalias elétricas, que podem ser associadas com estruturas geológicas, interferências superficiais, presença de água subterrânea, ou ainda à água com concentrações anômalas de íons. Os resultados não puderam ser considerados conclusivos, mas em conjunto com dados oriundos de outras técnicas, a geofísica elétrica contribuiu para a compreensão do correto tamanho das fraturas.

Os perfis levantados na porção central da área apresentaram baixa resistividade elétrica, o que pode ser atribuído a diferentes causas, todas envolvendo maior quantidade de água subterrânea ou maior espalhamento de íons de origem antrópica, devido a um aumento na condutividade hidráulica relacionado a presença de fraturas conectadas.

Ao observar as regiões de mais baixas resistividades (azuis) pode-se interpretar uma zona de baixa resistividade representada por uma faixa de orientação NE-SW. De acordo com os perfis das linhas A, B e C, de orientação NW-SE (Anexo I, figura 15), esta faixa de baixa resistividade apresenta mergulho para NW. As linhas E e F são aproximadamente paralelas a estas estruturas NESW, e por isso apresentam grande área marcada por baixas resistividades elétricas.

A partir dos perfis, verifica-se que as porções de mais baixa resistividades mais baixas estão dispostas segundo uma faixa alongada, de direção NE-SW, na parte central da área de detalhe $A$. As variações dos valores em profundidade sugere que esta faixa mergulha para NW.

As linhas de D a $G$ apontam um contato sub-vertical entre as porções de baixas e altas resistividades. Quando observados os contatos leste das zonas de 
baixa resistividade dos perfis (linhas $D$ a $G$ ) é possível se observar um alinhamento destes limites com uma direção aproximadamente N-S, sub-vertical.

\subsection{Análise de estruturas oriundas de técnicas BHTV}

Na perfilagem BHTV foram identificadas estruturas com abertura variável, de importância fundamental no fluxo da água subterrânea em meio fraturado. Essa importância é diretamente proporcional a abertura da fratura.

As estruturas foram classificadas com base na amplitude do sinal e nos dados de diâmetros dos poços oriundos do televisionamento acústico durante o processamento dos dados brutos. Esta é uma análise subjetiva, que pode levar à classificação de estruturas abertas como fechadas e vice-versa. Portanto, este passo do trabalho pode carregar erros nas análises a serem realizadas nas próximas etapas do trabalho. Em adição, devido à necessidade de instalação dos poços na sondagem na melhor posição para estes interceptarem fraturas, esta fase do trabalho pode definir uma posição duvidosa da seção filtrante em relação às fraturas.

As estruturas abertas (ou simplesmente fraturas) podem ser juntas ou falhas, dependendo se há ou não deslocamento relativo entre os dois blocos separados pela fratura. Este método de perfilagem acústica não permite classificar as fraturas como falhas ou juntas. As fraturas de pequena abertura a fechadas podem ser foliações, fraturas seladas ou fraturas preenchidas. No caso de fraturas preenchidas, o preenchimento deve ter características físicas (composição, densidade e porosidade) semelhantes ao substrato rochoso, para que estas não apresentem uma grande amplitude de sinal, que permite diferenciar uma fratura aberta de uma fechada.

A localização dos poços e de suas estruturas observadas são apresentadas no Anexo I, figura 16, para a área de detalhe $A$, e figura 17 para área de detalhe $B$. A localização dos poços e das estruturas observadas apenas nas seções filtrantes são apresentadas no Anexo I, figuras 18 e 19. 
$\mathrm{Na}$ área de detalhe A foram perfiladas 10 sondagens (PMR-01 a 10), nas quais foram identificadas 50 fraturas abertas e 111 fechadas. A figura 6.1 apresenta a projeção de todas as fraturas abertas da área nas sondagens do aqüífero fraturado. As fraturas abertas distribuem-se em fraturas horizontais, N-S com mergulho de baixo a médio, e fraturas de alto ângulo E-W a NE-SW.

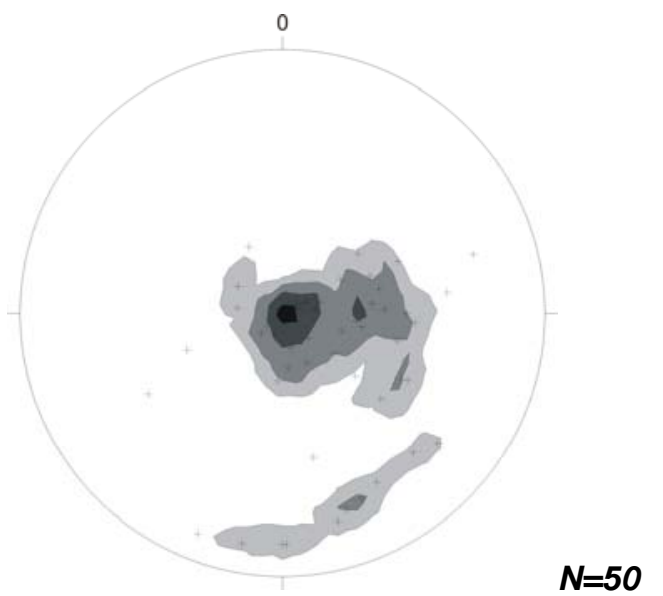

Figura 6.1 - Projeção dos pólos das fraturas abertas (para PMR-01 a 10), identificadas na perfilagem por imagem acústica.

0

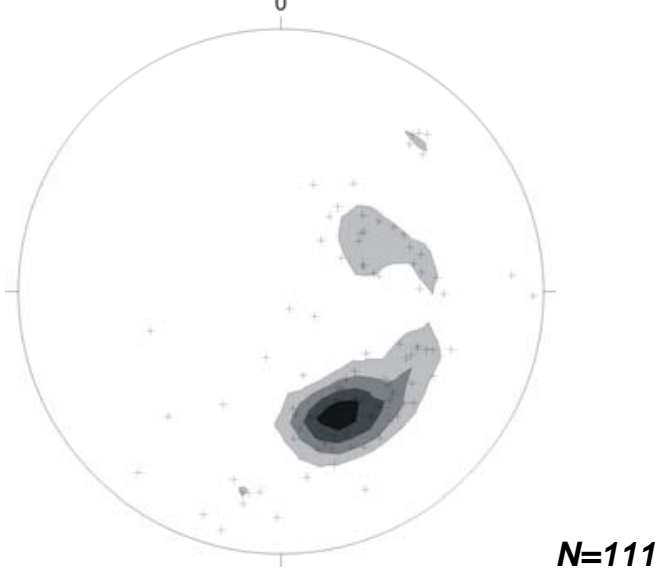

Figura 6.2 - Projeção dos pólos das fraturas de pequena abertura (para PMR 01 a 10), identificadas na perfilagem por imagem acústica (BHTV).

A figura 6.2 apresenta a projeção das estruturas com pequenas aberturas (fraturas seladas, veios ou foliação). Foram definidos dois grupos de estruturas fechadas, um com orientação ENE-WSW e mergulhos médios para NNW, e outro com direção NW-SE e mergulhos médios para SW. 
Quando as fraturas sub-horizontais não são levadas em consideração, a comparação entre as atitudes das fraturas abertas e das fraturas de pequena abertura indica forte semelhança. Analogamente, na avaliação de afloramentos é possível observar o paralelismo entre as fraturas da família NE-SW com as foliações dos afloramentos. Desta maneira, é possível considerar que as estruturas de pequena abertura, em sua maioria, são foliações, e as fraturas abertas podem pertencer aos diversos eventos rúpteis ocorridos na área.

$\mathrm{Na}$ área de detalhe B foram perfiladas quatro sondagens (PMR-12 a 15), nas quais foram identificadas 43 fraturas abertas e 18 estruturas de pequena abertura. A figura 6.3 apresenta a projeção dos pólos das fraturas abertas em que é possível distinguir 5 agrupamentos de estruturas, um sub-horizontal, dois de direção NE-SW com mergulho médio para NW e SE, um de direção N-S de mergulho alto para W, e um de direção WNW-ESSE com mergulho alto para NE. A figura 6.4 apresenta as estruturas fechadas, que definem duas tendências de estruturas, um grupo com ângulo de mergulho variável de direção NE-SW, e o segundo grupo de direção WNW-ESE a NNW-SSE com alto ângulo de mergulho para NE. Adicionalmente, tem-se um grupo com mergulho muito baixo tendendo à horizontal.

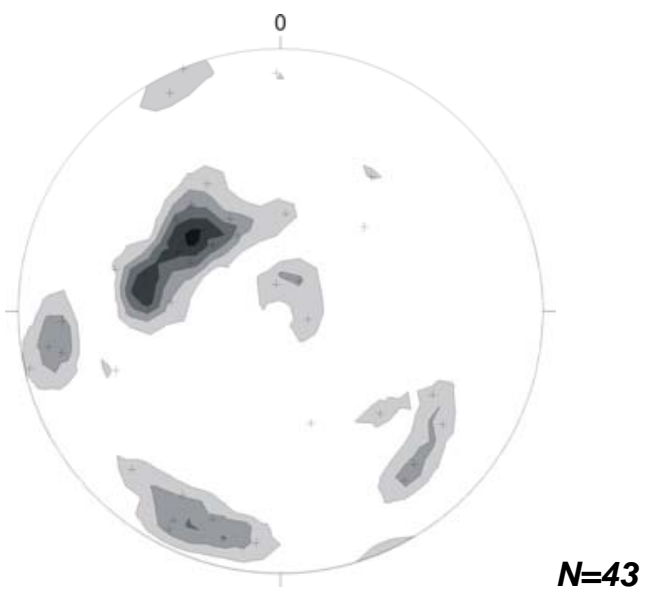

Figura 6.3 - Projeção dos pólos das fraturas abertas (PMR12 a 15), identificadas na perfilagem por imagem acústica (BHTV). 


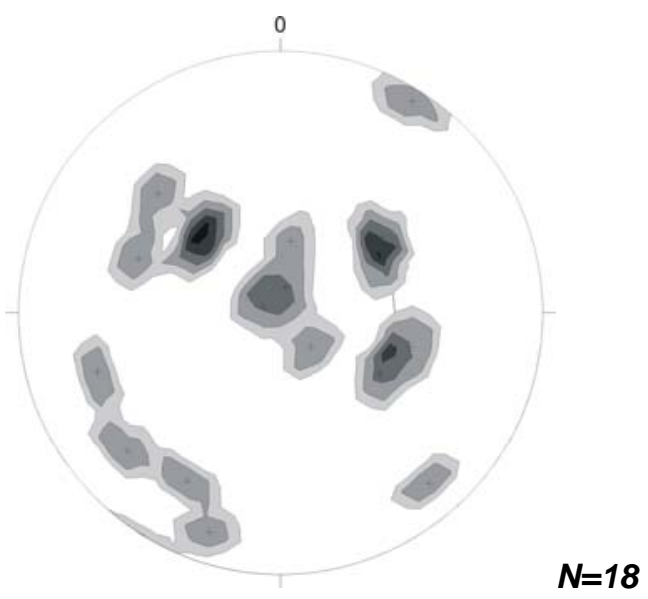

Figura 6.4 - Projeção do pólo de estruturas com pequena abertura (PMR12 a 15), identificadas na perfilagem por imagem acústica (BHTV).

Novamente, na área de detalhe B, a comparação entre as atitudes das fraturas abertas $\mathrm{e}$ as estruturas com pequenas aberturas indicou fortes similaridades. Assim, as estruturas abertas e as de pequenas aberturas podem pertencer aos mesmos sistemas de fraturas, variando apenas as aberturas das estruturas. Contudo, os estudos de afloramentos apontam que as estruturas de pequena abertura, de direção NE-SW com mergulho para NW, provavelmente são foliações.

A análise conjunta das estruturas abertas oriundas de BHTV nas áreas de detalhe A e B (figura 6.5) indicou 4 grupos (famílias de fraturas), que estão apresentadas em famílias na figura 6.6.

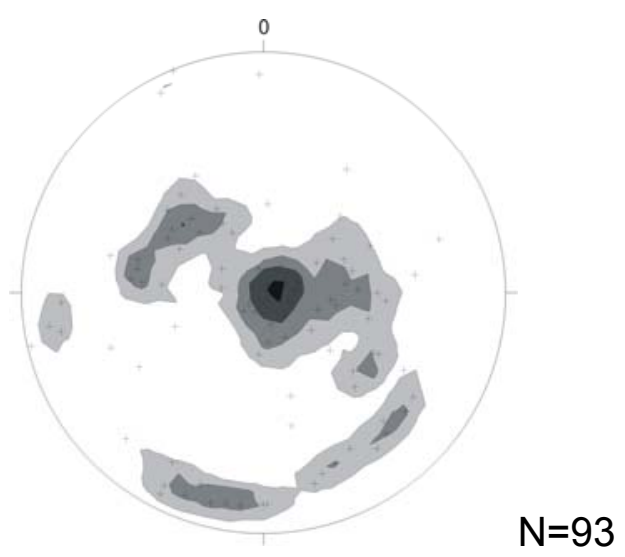

Figura 6.5 - Projeção dos pólos das fraturas abertas (PMR-01 a 15), identificadas em perfilagem por imagem acústica (BHTV). 

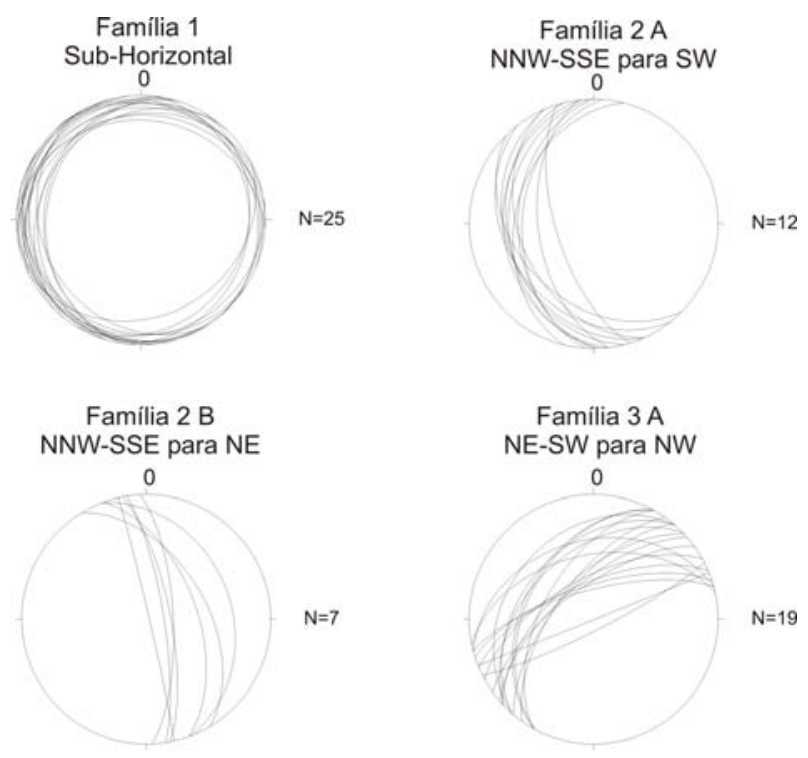

Familia $3 \mathrm{~A}$

NE-SW para NW

0

$N=7$

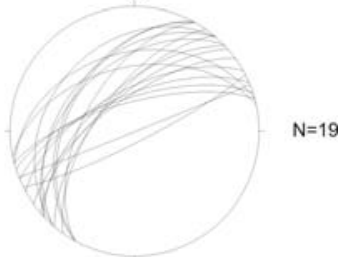

Familia 3 B

NE-SW para SE

Familia 4

WNW-ESE

0

0

Figura 6.6 - Projeção das fraturas abertas (PMR01 a 15), separadas em famílias e subfamílias, identificadas na perfilagem por imagem acústica (BHTV).

As 4 famílias e 2 sub-famílias de fratura estão descritas abaixo:

- família 1 (sub-horizontal) - estruturas de mergulho sub-horizontal (abaixo de $25^{\circ}$ ), e orientação indefinida;

- família 2 A (N-S com mergulhos para W) - estruturas com ângulo de mergulho médio e orientação média em N180/36W;

- família 2 B (N-S com mergulhos para E) - estruturas com ângulo de mergulho alto e orientação média em N170/75NE;

- família 3 A (NE-SW com mergulhos para NW) - estruturas predominantemente de alto ângulo de mergulho e atitude média em N36/66NW; 
- família 3 B (NE-SW com mergulhos para SE) - estruturas com médio ângulo de mergulho e atitude média de N40/36SE;

- família 4 (WNW-ESE) - estruturas com alto ângulo de mergulho predominantemente para NE e atitude média de N104/78NE.

As famílias 2 e 3 foram separadas em subfamílias $A$ e $B$, devido às similaridades de orientação (que indicam o caminho do fluxo da água subterrânea), porém com divergências nas direções e ângulos de mergulho. Foi necessária a separação em subfamílias para que as atitudes médias pudessem ser usadas nos cálculos de densidade de fraturas, uma vez que para os cálculos de densidade é necessária apenas uma atitude média para cada família.

As tabelas 2 e 3 (Anexo II) apresentam as estruturas observadas classificadas em abertas e fechadas e suas profundidades, todas separadas pelo poço de proveniência.

\subsection{Densidade de fraturamento}

Os dados provenientes dos cálculos das freqüências de fraturas nos poços foram usados para calcular a densidade linear de fraturas (razão do número de fraturas pelo comprimento do furo), e a densidade ponderada (razão do número de fraturas pelo comprimento de poço perpendicular ao plano médio da família da fratura).

Os dados da densidade de linear e ponderada de fraturas das áreas de detalhe $A$ e $B$ foram reunidos na tabela 6.1. A tabela apresenta um resumo das informações sobre as fraturas interceptadas por cada poço, as densidades linear e ponderada médias, separadas por família, por área de detalhe e total, e os desvios angulares entre os poços e as famílias.

$\mathrm{Na}$ área de detalhe $\mathrm{A}$ foram perfilados 293 metros de rocha sã por imagem acústica (PMR-01 a 10), o que permitiu identificar 50 fraturas abertas (densidade linear média de 0,171 fraturas por metro). Na área de detalhe B foram perfilados os poços PMR-12 a 15, com um comprimento total de 76 metros de rocha sã, o 
que resultou na identificação de 43 fraturas abertas (densidade linear média de 0,563 fraturas por metro).

O embasamento na área de detalhe $A$ possui uma densidade média ponderada de 0,262 fraturas por metro; as proporções das densidades de fraturas entre as famílias são: família $1 \mathrm{com} 31,06 \%$ (densidade ponderada 0,081), família 2A $17,07 \%$ (densidade ponderada 0,045), família 2B com 14,14\% (densidade ponderada de 0,037), família $3 \mathrm{~A}$ com 23,28\% (densidade ponderada de 0,061), família 3B não foi observada e família 4 com 14,45\% (densidade ponderada 0,038).

O embasamento na área de detalhe $\mathrm{B}$ possui uma densidade média ponderada de 1,174 fraturas por metro; as proporções das densidades de fraturas entre as famílias são: família 1 com 4,96\% (densidade ponderada 0,058), família $2 \mathrm{~A}$ com 1,51\% (densidade ponderada 0,018), família 2B com 19,73\% (densidade ponderada de 0,232), família $3 A$ com 18,71\% (densidade ponderada de 0,220), família 3B com 27,79\% (densidade ponderada de 0,326) e família 4 com 27,29\% (densidade ponderada 0,320 ).

O embasamento das áreas de detalhe como um todo possui uma densidade média ponderada de 0,472 fraturas por metro; as proporções das densidades de fraturas entre as famílias são: família 1 com 16,48\% (densidade ponderada 0,078 ), família $2 \mathrm{~A}$ com $8,42 \%$ (densidade ponderada 0,040 ), família $2 \mathrm{~B}$ com 19,64\% (densidade ponderada de 0,093), família 3 A com 18,59\% (densidade ponderada de 0,088), família 3B com 15,18\% (densidade ponderada de 0,072) e família 4 com 21,69\% (densidade ponderada 0,102).

A comparação das densidades ponderadas da família 1 entre as duas áreas indicou que estas variam dentro da mesma ordem de grandeza. Quando comparadas as proporções relativas entre as famílias, a família 1 na área de detalhe $A(31,06 \%)$ apresenta uma diferença acentuada em relação à família 1 na área de detalhe $B(4,96 \%)$.

A comparação da família 1 mostra que o maciço da área de detalhe $B$ é mais fraturado, porém as fraturas da família 1 mantêm os mesmos valores de 
densidade de fraturas. Como a família 1 foi provavelmente originada por alívio de carga, as densidades de fraturas devem ser semelhantes para toda a região afetada pelo soerguimento.

A comparação das densidades ponderadas de fraturas em relação às densidades lineares indicou que, de modo geral, as densidades ponderadas são maiores que as lineares. As famílias $2 \mathrm{~B}$ e 4 apresentaram valores de densidade ponderada de quase o dobro da densidade linear, provavelmente pelo fato de possuírem os maiores mergulhos e maiores desvios angulares entre as sondagens e as orientações das diferentes famílias de fraturas. 


\begin{tabular}{|c|c|c|c|c|c|c|c|c|c|c|c|c|c|c|c|c|}
\hline & Orientação & |PMR-1 & |PMR-2 & |PMR-3 & |PMR-4 & |PMR-5 & $\overline{\mid \overline{P P M R}-6}$ & |PMR-7 & |PMR-8 & |PMR-9 & PMR-10 & |PMR-12 & |PMR-13 & $\overline{\mid \overline{\mid P M R-14}}$ & |PMR-15 & Total \\
\hline & & vertical & vertical & vertical & vertical & $200 / 60$ & $128 / 63$ & $157 / 63$ & $90 / 62$ & $132 / 63$ & $160 / 60$ & $128 / 60$ & $180 / 62$ & $33 / 64$ & $259 / 61$ & \\
\hline $\mid \overline{\text { Família } 1}$ & Horizontal & 5 & 4 & 4 & 1 & 0 & 2 & 0 & 5 & 0 & 1 & 0 & 0 & 1 & 2 & 25 \\
\hline Família 2 A & $270 / 36$ & 0 & 0 & 0 & 1 & 0 & 5 & 1 & 2 & 0 & 2 & 0 & 0 & 1 & 0 & 12 \\
\hline Família 2 B & $83 / 78$ & 0 & 0 & 0 & 0 & 0 & 1 & 0 & 0 & 0 & 1 & 0 & 0 & 0 & 5 & 7 \\
\hline Família 3 A & $316 / 66$ & 0 & 0 & 0 & 0 & 3 & 1 & 5 & 0 & 0 & 2 & 2 & 6 & 0 & 0 & 19 \\
\hline Família 3B & $130 / 36$ & 0 & 0 & 0 & 0 & 0 & 0 & 0 & 0 & 0 & 0 & 1 & 0 & 11 & 4 & 16 \\
\hline Familia 4 & $14 / 78$ & 0 & 3 & 0 & 0 & 0 & 0 & 0 & 0 & 0 & 1 & 0 & 7 & 2 & 1 & 14 \\
\hline Total & - & 5 & 7 & 4 & 2 & 3 & $\overline{9}$ & 6 & 7 & 0 & 7 & 3 & 13 & 15 & 12 & 93 \\
\hline $\mid$ Perf. Total & - & 21,500 & 24,500 & 27,630 & 23,300 & 30,000 & 30,000 & 30,000 & 29,100 & 49,400 & 27,700 & 19,350 & \begin{tabular}{l|}
19,910 \\
\end{tabular} & 18,745 & 18,395 & 369,530 \\
\hline Perf. Fam1 & Vertical & 21,500 & 24,500 & 27,630 & 23,300 & 25,985 & 26,733 & 26,733 & 25,697 & 44,021 & 23,993 & 16,760 & \begin{tabular}{l|}
17,582 \\
\end{tabular} & 8,227 & 8,927 & 321,588 \\
\hline Perf. Fam2A & $90 / 54$ & 17,398 & 19,826 & 22,358 & \begin{tabular}{|l|}
18,854 \\
\end{tabular} & 18,066 & 28,009 & 24,876 & 28,817 & 45,477 & 22,128 & 18,066 & \begin{tabular}{l|l|}
14,327 \\
\end{tabular} & 16,236 & 7,784 & 302,222 \\
\hline Perf. Fam2B & $263 / 12$ & 4,485 & 5,110 & 5,763 & 4,860 & 12,218 & 4,197 & 2,115 & 8,039 & 5,200 & 1,953 & 3,041 & 4,830 & 1,648 & 12,074 & 75,534 \\
\hline Perf. Fam3A & $136 / 24$ & 8,756 & 9,978 & 11,253 & 9,489 & 16,352 & 23,321 & 22,302 & 19,101 & 38,402 & 21,226 & 15,658 & 13,329 & 5,179 & 2,255 & 216,600 \\
\hline Perf. Fam3B & $310 / 54$ & 17,398 & 19,826 & 22,358 & 18,854 & 18,066 & 13,635 & 14,558 & 14,563 & 22,452 & 12,589 & 7,881 & 10,559 & 14,364 & 16,244 & 223,347 \\
\hline Perf. Fam4 & $194 / 12$ & 4,485 & 5,110 & 5,763 & 4,860 & 20,083 & 11,255 & 16,352 & 2,052 & 19,329 & 16,292 & 7,259 & 12,537 & 4,229 & 7,198 & 136,805 \\
\hline \multicolumn{17}{|c|}{ Densidade ponderada das famílias por poços } \\
\hline Densidade fa & mília 1 & 0,233 & 0,163 & 0,145 & 0,043 & 0,000 & 0,075 & 0,000 & 0,195 & 0,000 & 0,042 & 0,000 & 0,000 & 0,122 & 0,224 & 0,078 \\
\hline$\overline{\text { Densidade fa }}$ & mília $2 \mathrm{~A}$ & 0,000 & 0,000 & 0,000 & 0,053 & 0,000 & 0,179 & 0,040 & 0,069 & 0,000 & 0,090 & 0,000 & 0,000 & 0,062 & 0,000 & 0,040 \\
\hline Densidade fa & mília 2 B & 0,000 & 0,000 & 0,000 & 0,000 & 0,000 & 0,238 & 0,000 & 0,000 & 0,000 & 0,512 & 0,000 & 0,000 & 0,000 & 0,414 & 0,093 \\
\hline Densidade fa & mília $3 \mathrm{~A}$ & 0,000 & 0,000 & 0,000 & 0,000 & 0,183 & 0,043 & 0,224 & 0,000 & 0,000 & 0,094 & 0,128 & 0,450 & 0,000 & 0,000 & 0,088 \\
\hline Densidade fa & mília 3 B & 0,000 & 0,000 & 0,000 & 0,000 & 0,000 & 0,000 & 0,000 & 0,000 & 0,000 & 0,000 & 0,127 & 0,000 & 0,766 & 0,246 & 0,072 \\
\hline Densidade fa & mília 4 & 0,000 & 0,587 & 0,000 & 0,000 & 0,000 & 0,000 & 0,000 & 0,000 & 0,000 & 0,061 & 0,000 & 0,558 & 0,473 & 0,139 & 0,102 \\
\hline \multicolumn{16}{|c|}{ Ángulo entre atitude do pólo das famílias e orientação do poço } & \\
\hline Familia / S & ondagem & TPMR-1 & TPMR-2 & PMR-3 & PMR-4 & PMR-5 & TPMR-6 & PMR-7 & PMR-8 & PMR-9 & PMMR-10 & TPMR-12 & PMR-13 & PMR-14 & PMR-15 & \\
\hline Famíl & & 0 & 0 & 0 & 0 & 30 & 27 & 27 & 28 & 27 & 30 & 30 & 28 & 64 & 61 & \\
\hline Famili & $\overline{\mathrm{a} 2 \mathrm{~A}}$ & 36 & 36 & 36 & 36 & 53 & 21 & 34 & 8 & 23 & 37 & 21 & 44 & 30 & 65 & \\
\hline Famili & $\overline{\mathrm{a} 2 \mathrm{~B}}$ & 78 & 78 & 78 & 78 & 66 & 82 & 86 & 74 & 84 & 86 & 81 & 76 & 85 & 49 & \\
\hline Famili & $\mathrm{a} 3 \mathrm{~A}$ & 66 & 66 & 66 & 66 & 57 & 39 & 42 & 49 & 39 & 40 & 36 & 48 & 74 & 83 & \\
\hline Famili & $\overline{\mathrm{a} 3 \mathrm{~B}}$ & 36 & 36 & 36 & 36 & 53 & 63 & 61 & 60 & 63 & 63 & 66 & 58 & 40 & 28 & \\
\hline \multicolumn{2}{|c|}{ Família 4} & 78 & 78 & 78 & 78 & 48 & 68 & 57 & 86 & 67 & 54 & 68 & 51 & 77 & 67 & \\
\hline & Densidade T & Total (fratura & as/metro) & & \multicolumn{6}{|c|}{ Densidade Area detalhe A (fraturas/metro) } & \multicolumn{6}{|c|}{ Densidade Area detalhe B (fraturas/metro) } \\
\hline & $\begin{array}{l}\text { Densid. } \\
\text { Tot. perf. }\end{array}$ & $\%$ & $\begin{array}{l}\text { Dens. } \\
\text { Pond. }\end{array}$ & $\%$ & $\begin{array}{l}\text { Perfur. } \\
\text { Tot.(m) }\end{array}$ & \begin{tabular}{|c|} 
Densid. \\
Tot. perf.
\end{tabular} & $\%$ & \begin{tabular}{|c|}
$\begin{array}{c}\text { Perf. Direc. } \\
\text { tot. }\end{array}$ \\
\end{tabular} & $\begin{array}{l}\text { Dens. } \\
\text { Pond. }\end{array}$ & $\%$ & $\begin{array}{l}\text { Perfur. } \\
\text { Tot.(m) }\end{array}$ & \begin{tabular}{c|} 
Densid. \\
Tot. perf.
\end{tabular} & $\%$ & \begin{tabular}{|c|} 
Perf. \\
Direc. tot.
\end{tabular} & $\begin{array}{l}\text { Dens. } \\
\text { Pond. }\end{array}$ & $\%$ \\
\hline Fam. 1 & 0,068 & 26,88 & 0,078 & 16,48 & \multirow{7}{*}{293,130} & 0,075 & 44,00 & 270,092 & 0,081 & 31,06 & \multirow{7}{*}{76,400} & 0,039 & 6,98 & 51,496 & 0,058 & 4,96 \\
\hline Fam. $2 \mathrm{~A}$ & 0,032 & 12,90 & 0,040 & 8,42 & & 0,038 & 22,00 & 245,809 & 0,045 & 17,07 & & 0,013 & 2,33 & 56,413 & 0,018 & 1,51 \\
\hline Fam. 2 B & 0,019 & 7,53 & 0,093 & 19,64 & & 0,007 & 4,00 & 53,941 & 0,037 & 14,14 & & 0,065 & 11,63 & 21,592 & 0,232 & 19,73 \\
\hline Fam. $3 \mathrm{~A}$ & 0,051 & 20,43 & 0,088 & 18,59 & & 0,038 & 22,00 & 180,180 & 0,061 & 23,28 & & 0,105 & 18,60 & 36,421 & 0,220 & 18,71 \\
\hline Fam. 3 B & 0,043 & 17,20 & 0,072 & 15,18 & & 0,000 & 0,00 & 174,299 & 0,000 & 0,00 & & 0,209 & 37,21 & 49,048 & 0,326 & 27,79 \\
\hline Fam. 4 & 0,038 & 15,05 & 0,102 & 21,69 & & 0,014 & 8,00 & 105,582 & 0,038 & 14,45 & & 0,131 & 23,26 & 31,223 & 0,320 & 27,29 \\
\hline Total & 0,252 & 100,00 & 0,472 & 100,00 & & 0,171 & 100,00 & 1029,904 & 0,262 & 100,00 & & 0,563 & 100,00 & 246,192 & 1,174 & 100,00 \\
\hline
\end{tabular}

Tabela 6.1 - Sumário das fraturas abertas das áreas de detalhe (células em amarelo são resultados de cálculos entre dados da tabela; células brancas representam dados de entrada na planilha). 


\subsection{Ensaios de bombeamento}

No Anexo I, figura 20, são apresentados os gráficos de nível de água dos poços de monitoramento e as linhas equipotenciais do aqüífero fraturado.

$\mathrm{Na}$ avaliação do ensaio é considerado o comportamento da variação do nível da água subterrânea em função do tempo, observando-se quando ocorreu uma mudança de comportamento e qual a magnitude variação do nível da água. Também são considerados a posição dos poços em relação a possíveis estruturas maiores e a individualização das fraturas observadas na seção filtrante de cada poço.

Seguindo os critérios citados, os resultados do teste de bombeamento indicam que:

- ocorre uma forte conexão do PP-01 com o topo do aqüífero fraturado representado pelo PMR-11;

- o PP-01 está fortemente conectado com as estruturas do aqüífero fraturado ao norte da área (PMR-02 e 03);

- as estruturas do aqüífero fraturado na área dos poços PMR-01B e 06 estão moderadamente conectadas com o PP-01;

- a água proveniente das estruturas dos PMR-01B e 06 provavelmente migraram para recuperar os níveis da água nas estruturas que fornecem água para os poços PMR-02, 03 e 11; Isso se explica devido ao fato de que depois de cessado o bombeamento a carga dos poços PMR-01B e 06 continuou caindo;

- as estruturas do PMR-06 estão mais diretamente conectadas com o bombeamento do que as estruturas do PMR-01B, pois apesar de ambas apresentarem comportamento idêntico no tempo, houve uma queda de 4,5 metros no primeiro, enquanto que o PMR-01 B perdeu apenas 0,5 metros de coluna de água;

- o PP-01 está fracamente conectado com as fraturas do aqüífero fraturado no centro da área (PMR-07), onde os níveis de água subiram como resposta ao 
teste de bombeamento; esta é uma condição rara, em que as fraturas do PP01 podem não ter nenhuma conexão com as estruturas do poço PMR-07, e estas estarem sofrendo uma recarga oriunda do aqüífero poroso inconsolidado (o teste foi realizado em uma estação de chuvas); o fenômeno pode também ter causa relacionada com estruturas de pequena abertura, orientações de fraturas sub-verticais e relações de pressão entre sistemas de fratura;

- as estruturas do PP-01 não apresentam conexão com as estruturas dos PMR-04 e 05, onde os níveis de água subiram devido à recarga natural (o teste foi realizado durante a estação de chuvas).

Os resultados dos ensaios de bombeamento para obtenção dos dados dos parâmetros hidráulicos dos poços são apresentados no Anexo III, no qual também constam os resultados das resoluções matemáticas do programa computacional Aquifer Test.

Os parâmetros hidráulicos do aqüífero fraturado nas imediações dos poços ensaiados (PP-01 e PMR-11) foram:

- PMR-11 condutividade hidráulica: $7,23 \times 10^{-5} \mathrm{~cm} / \mathrm{s}$ e transmissividade $1,44 \times 10^{-1} \mathrm{~cm}^{2} / \mathrm{s}$;

- PP-01 condutividade hidráulica: $1,66 \times 10^{-3} \mathrm{~cm} / \mathrm{s}$, transmissividade $1,33 \times 10^{1} \mathrm{~cm}^{2} / \mathrm{s}$ e coeficiente de armazenamento $8,90 \times 10^{-2}$.

\subsection{Testes de recuperação}

Os métodos matemáticos para a análise dos dados obtidos de um teste de rebaixamento ou recuperação são comumente desenvolvidos exclusivamente para meios porosos, regidos pela lei de Darcy. Os métodos mais comuns são os de Hvorslev (1951) e Bouwer-Rice (1976).

Barker \& Black (1983) propuseram uma solução matemática para testes de recuperação em rocha fraturada, considerando fraturas horizontais que interceptam o poço e interações com espaços nas matrizes de rocha entre as 
fraturas. Barker \& Black (1983) compararam o método desenvolvido com o de Cooper et al. (1967), demonstrando que a transmissividade estimada no modelo homogêneo apresentou diferença de menos de uma ordem de magnitude a mais do que as de fraturas.

Para que os modelos matemáticos de fluxo radial sob a lei de Darcy sejam válidos nos estudos, o valor de transmissividade das fraturas individualizadas tem de ser de mesma ordem de grandeza do que a do REV do aqüífero.

Assim, os métodos matemáticos clássicos (Hvorslev 1951, Cooper et al. 1967, e Bouwer \& Rice 1976) são perfeitamente admitidos na resolução de ensaios de testes de rebaixamento e recuperação. Entretanto, quando as diferenças de transmissividade entre o REV e as fraturas individualizadas são muito grandes e tornam o fluxo do tipo linear, os resultados dos modelos matemáticos clássicos comparados aos resultados do modelo específico de meio fraturado podem ser maiores do que uma ordem de magnitude (Barker \& Black 1983).

Em geral, no presente trabalho, não houve evidências de que o fluxo da água subterrânea não seja do tipo radial e regido pelas leis de Darcy. Desta maneira, neste estudo foi empregada uma estimativa de condutividade hidráulica (K) com ensaios de recuperação e resoluções com uso do método de Hvorslev (1951).

Os resultados das condutividades hidráulicas calculadas para cada seção de filtro com uso do método de Hvorslev (1951) estão apresentados abaixo:

- PMR-01B condutividade hidráulica: $1,55 \times 10^{-8} \mathrm{~cm} / \mathrm{s}$;

- PMR-02 condutividade hidráulica: $3,10 \times 10^{-7} \mathrm{~cm} / \mathrm{s}$;

- PMR-03 condutividade hidráulica: entre $3,00 \times 10^{-6}$ e $4,00 \times 10^{-5} \mathrm{~cm} / \mathrm{s}$;

- PMR-04 condutividade hidráulica: $1,69 \times 10^{-6} \mathrm{~cm} / \mathrm{s}$;

- PMR-05 condutividade hidráulica: $5,40 \times 10^{-8} \mathrm{~cm} / \mathrm{s}$; 
- PMR-06 condutividade hidráulica: $2,01 \times 10^{-8} \mathrm{~cm} / \mathrm{s}$;

- PMR-07 condutividade hidráulica: $1,40 \times 10^{-7} \mathrm{~cm} / \mathrm{s}$;

- PMR-12 condutividade hidráulica: $5,40 \times 10^{-8} \mathrm{~cm} / \mathrm{s}$;

- PMR-13 condutividade hidráulica: $2,45 \times 10^{-7} \mathrm{~cm} / \mathrm{s}$;

- PMR-14A condutividade hidráulica: $9,00 \times 10^{-6} \mathrm{~cm} / \mathrm{s}$;

- PMR-14B condutividade hidráulica: $1,20 \times 10^{-6} \mathrm{~cm} / \mathrm{s}$;

- PMR-15 condutividade hidráulica: entre 1,00 e 3,00 ×10 $10^{-5} \mathrm{~cm} / \mathrm{s}$.

As condutividades hidráulicas variaram de $1,55 \times 10^{-8}$ a $2 \times 10^{-5} \mathrm{~cm} / \mathrm{s}$, com média de 2,98 $\times 10^{-6}$ e desvio padrão de 5,69 $\times 10^{-6}$; a soma da média com o desvio padrão apresenta valores anômalos para condutividades acima de 8,66 x $10^{-6} \mathrm{~cm} / \mathrm{s}$.

Com base nesta análise estatística, as fraturas interceptadas pelos poços PMR-14A e 15, e talvez o PMR-03, apresentam valores de condutividade hidráulica anômalos. Estes poços podem estar interceptando fraturas com fluxo do tipo linear, ou não regida pela lei de Darcy, de maneira que as resoluções matemáticas clássicas não deveriam ser aplicadas.

Os dados e gráficos do ensaio de recuperação são apresentados no Anexo III.

\subsection{Resultados de monitoramento de cargas hidráulicas}

O monitoramento das cargas hidráulicas dos poços do aqüifero fraturado teve como objetivo estudar a conexão entre os poços, comparando os dados de estruturas presentes nas seções filtrantes com a variação das cargas hidráulicas dos poços. Conseqüentemente, por meio das cargas hidráulicas foi estimada a superfície potenciométrica para o topo do aqüífero cristalino fraturado da área de detalhe $\mathrm{A}$.

As figuras 21 e 22 (Anexo I) apresentam os gráficos das variações das cargas hidráulicas dos poços do aqüífero fraturado para as áreas de detalhe $\mathrm{A} e$ 
$B$, respectivamente. A variação corresponde a um período de 25 dias para a área de detalhe $A$, e 6 dias para área de detalhe B. A figura 21 (Anexo I) apresenta também curvas equipotenciais das cargas hidráulicas dos poços PMR de 1 a 10. As cargas hidráulicas são apresentadas na tabela 6.2 a seguir.

\begin{tabular}{||c|c|c|c|c||}
\hline Poço & $\begin{array}{c}\text { Comprim. } \\
\text { do tubo } \\
\mathbf{( m )}\end{array}$ & Cota $\mathbf{( m )}$ & $\begin{array}{c}\text { Nível da água } \\
\mathbf{1 0 / 1 0 / 0 6}(\mathbf{m})\end{array}$ & $\begin{array}{c}\text { Cargas hidráulicas } \\
\mathbf{1 0 / 1 0 / 0 6}(\mathbf{m})\end{array}$ \\
\hline \hline PMR-1A & 39,55 & 811,39 & 27,94 & 783,45 \\
\hline PMR-1B & 52,10 & 811,39 & 36,58 & 774,81 \\
\hline PMR-02 & 37,86 & 793,07 & 27,13 & 765,94 \\
\hline PMR-03 & 46,50 & 789,52 & 26,49 & 763,03 \\
\hline PMR-04 & 52,30 & 801,59 & 20,44 & 781,15 \\
\hline PMR-05( $\left.{ }^{*}\right)$ & 46,00 & 807,55 & 24,14 & 783,41 \\
\hline PMR-06( $\left.{ }^{*}\right)$ & 60,00 & 811,34 & 39,63 & 771,71 \\
\hline PMR-07( $\left.{ }^{*}\right)$ & 52,00 & 811,37 & 22,33 & 789,04 \\
\hline PMR-08( $\left.{ }^{*}\right)$ & 57,00 & 811,09 & 46,89 & 764,20 \\
\hline PMR-09( $\left.{ }^{*}\right)$ & 50,10 & 795,92 & 22,23 & 773,69 \\
\hline PMR-10( $\left.{ }^{*}\right)$ & 57,00 & 811,64 & 20,77 & 790,87 \\
\hline PMR-11 & 70,75 & 810,80 & 25,00 & 785,80 \\
\hline \hline
\end{tabular}

Tabela 6.2 - Medições de nível do topo do aqüífero fraturado na área de detalhe A. (*) Poços inclinados; os níveis de água foram corrigidos, multiplicando os n.a. pelo seno de $60^{\circ}$.

O mapa de superfícies potenciométricas da figura 21 (Anexo I) mostra uma grande influência das estruturas $\mathrm{N}-\mathrm{S}$ na superfície potenciométrica. Aparentemente estas estruturas N-S causam uma anisotropia nas condutividades hidráulicas, condicionando a direção do fluxo da água subterrânea na área. A água preferencialmente flui em direção ao centro da área, e a partir daí o fluxo aponta para o norte.

Ao longo do lineamento $\mathrm{N}-\mathrm{S}$, em um intervalo de $200 \mathrm{~m}$ entre a linha equipotencial de 765 e 790 m, o gradiente hidráulico medido foi de $12,5 \%$. A comparação das cargas hidráulicas do PMR-01A com o PMR-01B indica a existência de um gradiente hidráulico vertical descendente de $55 \%$, neste trecho.

No período monitorado na área de detalhe $\mathrm{A}$, os dados de chuva para a região (Anexo I, figura 21) apontam que houve um pico no $18^{\circ}$ dia de 
monitoramento e a partir deste dia as chuvas cessaram ou mantiveram-se em patamares mais baixos.

Os poços PMR-10, 7, 6, 2 e 3 (listados de sudoeste para nordeste) apresentaram comportamento similar, com picos de carga hidráulica coincidente com os picos de chuva no início e passando para uma tendência decrescente. É interessante notar que o alinhamento destes pontos segundo a direção NE-SW corresponde à direção da família 3 e também à direção de um pequeno vale situado ao norte desta área, vale este provavelmente condicionado por um lineamento NE-SW. Os poços PMR-02 e 06 podem ser considerados alinhados segundo N-S e, desta maneira, entende-se que o comportamento similar entre os pontos PMR-02 e 06 se deve a presença de estruturas, que condicionam o fluxo, alinhadas com a mesma direção N-S.

Os poços PMR-09 e 05 mantiveram suas cargas hidráulicas estáveis. O PMR-09 não apresentou nenhuma fratura, portanto este deve refletir a água da matriz rochosa, que apresenta permeabilidade baixíssima. Já o poço PMR-05 registra uma variação muito brusca nas cargas hidráulicas por volta do $21^{\circ}$ dia, de maneira que o gráfico apresenta apenas um pico isolado, em comparação com as chuvas que apresentaram três picos em escala crescente. Dessa forma este poço foi considerado como de carga constante.

O poço PMR-04 apresenta comportamento muito similar ao das chuvas, porém registrando um atraso de aproximadamente 20 dias entre os maiores picos. De maneira geral o PMR-08 também apresenta esta tendência, onde após 20 dias de pico de chuva, o poço apresentou a carga hidráulica mais alta.

Os poços PMR-01 A e B apresentaram comportamento completamente distinto entre eles. O poço mais raso (PMR-01 A) mostra uma variação expressiva e brusca, provavelmente por encontrar-se muito próximo do contato da rocha com o aqüífero poroso. O poço mais fundo (PMR-01 B) apresenta um comportamento mais estável, refletindo apenas um leve aumento da carga hidráulica em função das chuvas. 
As maiores alterações de carga hidráulica foram registrados nos poços PMR-01A e PMR-08, que variaram cerca de três e dois metros, respectivamente, e os poços PMR-04 e 07, que variaram por volta de um metro.

Para a área de detalhe B não foi elaborado um mapa de linhas equipotenciais de carga hidráulica, uma vez que a presença de apenas 4 poços (PMR-12 a 15) foi considerada insuficiente para traçar as isopotenciais.

A tabela 6.3 apresenta as cargas hidráulicas calculadas. Observa-se que, dentro da normalidade, o ponto de montante topográfico da área (porção leste) apresenta a maior carga hidráulica dos poços. Porém, a mais baixa carga hidráulica não corresponde ao poço PMR-15, que é o mais próximo da jusante topográfica (rio Cotia). O poço de mais baixa carga hidráulica foi o PMR-13, que esta situado na porção central da área. Assim, percebe-se que o fluxo não aponta para a jusante topográfica e sim para as estruturas do PMR-13, e estas apresentam conexão com a área de descarga do aqüífero.

Entre os poços PMR-14A e B o fluxo aponta uma leve tendência vertical ascendente de $9 \%$. O fluxo ascendente corrobora com a indicação de que o rio Cotia é a área de descarga do topo do aqüífero fraturado.

\begin{tabular}{||c|c|c|c|c||}
\hline Poço & $\begin{array}{c}\text { Comprim. } \\
\text { do tubo }(\mathrm{m})\end{array}$ & Cota $(\mathrm{m})$ & $\begin{array}{c}\text { Nível da água } \\
03 / 02 / 06(\mathrm{~m})\end{array}$ & $\begin{array}{c}\text { Cargas hidráulicas } \\
\text { 03/02/06 }(\mathrm{m})\end{array}$ \\
\hline PMR-12 $\left(^{*}\right)$ & 21,00 & 754,65 & 1,28 & 753,37 \\
\hline PMR-13 $\left(^{*}\right)$ & 33,00 & 753,80 & 5,03 & 748,77 \\
\hline PMR-14A $\left(^{*}\right)$ & 32,00 & 756,65 & 7,48 & 749,17 \\
\hline PMR-14B $\left(^{*}\right)$ & 41,00 & 756,65 & 6,88 & 749,77 \\
\hline PMR-15 $\left(^{*}\right)$ & 29,00 & 756,66 & 6,98 & 749,68 \\
\hline
\end{tabular}

Tabela 6.3 - Medições de nível da água do topo do aqüífero fraturado na área de detalhe B. $\left(^{*}\right)$ Poços inclinados; os níveis de água foram corrigidos, multiplicando os n.a. pelo seno de $60^{\circ}$.

A figura 22 (Anexo I) apresenta as variações das cargas hidráulicas dos poços monitorados (PMR-12, 13 e 14B) comparando-as com as chuvas do mesmo período. É possível observar que os comportamentos dos poços PMR- 
13 e 14B são similares, variando de 0,1 a 0,2 metros, enquanto que o PMR-12 subiu por volta de 1 metro.

As cargas hidráulicas dos poços PMR-13 e 14B aumentaram logo após a chuva do $10^{\circ}$ dia, e mantiveram essa tendência de aumento até entre o 11 e $12^{\circ}$ dia, quando passaram a diminuir as cargas hidráulicas novamente. $O$ poço PMR-14B apresentou resposta mais rápida às chuvas, demonstrado pela recuperação dos níveis da água a partir da metade do $14^{\circ}$ dia, enquanto que o PMR-13 não apresentou um novo aumento das cargas hidráulicas no período monitorado. Este atraso entre a variação dos níveis da água dos dois poços também indica que a água subterrânea apresenta resposta à chuva inicialmente no poço PMR-14 e depois no PMR-13, como observado nas cargas hidráulicas dos poços.

As diferenças das cargas do PMR-14 e 15 para o 13, sugerem duas alternativas: ou ocorre recarga na planície de alagamento do rio Cotia e esta recarga colabora com aporte de água nas fraturas interceptadas pelo poço PMR13, ou quando se eleva o nível da água do rio Cotia ocorre um aumento das cargas hidráulicas das fraturas do PMR-13. Ambas as respostas apontam que existe forte conexão das fraturas que condicionaram o alinhamento deste segmento do rio Cotia com as fraturas interceptadas pelo PMR-13. 


\section{TECTÔNICA RÚPTIL APLICADA À HIDROGEOLOGIA EM AQÜÍFERO CRISTALINO FRATURADO}

\subsection{Análise da tectônica rúptil da área de semi-detalhe}

Para a análise da tectônica rúptil, o presente trabalho apresenta comparações entre análise morfométrica, estudo de afloramentos rochosos e de estruturas provenientes de sondagens das áreas de detalhe. Os dois primeiros fornecem informações em caráter regional, que podem ser aplicadas ao estudo de detalhe, enquanto as estruturas provenientes de sondagens na área de detalhe permitem um melhor entendimento da área de semi-detalhe.

\subsubsection{Análise dos dados estruturais e comparação com a evolução das deformações rúpteis da área de semi-detalhe}

Para a área de semi-detalhe, a análise conjunta dos dados morfométricos e dos dados de estruturas rúpteis permitiu a comparação com o quadro estabelecido para as deformações do RCSB (figura 4.9).

Os lineamentos de direção N-S e E-W foram aparentemente ativos na mesma escala de tempo; as famílias de juntas NNW-SSE e WNW-ESE apresentam direções muito aproximadas àquelas dos lineamentos. Estas famílias foram originadas sob campo de esforços com compressão de direção NW-SE e distensão NE-SW, do evento de transcorrência dextral (idade atribuída regionalmente ao Pleistoceno). A alguns lineamentos E-W podem relacionar-se às estruturas neoproterozóicas das zonas de cisalhamento.

Os lineamentos de direção NW-SE não se destacam nas superfícies de base. Eles também podem ser relacionados com as estruturas das famílias WNW-ESE e, neste caso, estes lineamentos também seriam relacionados à transcorrência dextral de binário E-W.

Os lineamentos de direção NE-SW, apesar de serem dos mais expressivos nas anomalias, são claramente superpostos pelos lineamentos de direções N-S e E-W. Estes lineamentos são alinhados com as estruturas das 
famílias NE-SW identificadas nos levantamentos de campo. Eles podem ter sido gerados e reativados sob diferentes campos de esforços: i) relacionados às grandes zonas de cisalhamento dextrais neoproterozóicas; ii) transcorrência sinistral de binário E-W, com compressão distensão NW-SE e compressão NESW (Neocretáceo- Paleoceno ou Neógeno); iii) distensão NNW-SSE (Eoceno Oligoceno).

\subsubsection{Tectônica rúptil da área de estudos de semi-detalhe aplicada às áreas de detalhe}

A comparação entre as estruturas caracterizadas na escala de semidetalhe com as caracterizadas na escala de detalhe permitiu a definição das seguintes famílias:

- família 1 - estruturas com mergulho sub-horizontal (menor do que de $25^{\circ}$ ), com orientação indefinida; correspondente à família sub-horizontal da análise dos afloramentos rochosos (Capítulo 5);

- família 2 - estruturas com direção geral N-S e mergulhos para W (subfamília 2A) e direção geral NNW-SSE com mergulhos para NE (subfamília 2B), e orientações médias N180/36W e N170/75NE, respectivamente;

- família 3 - estruturas com direção geral NE-SW e mergulhos moderados para NW (sub-família 3A) e NE-SW com mergulho moderados para SE (sub-família 3B), e atitudes médias N036/66NW e N040/36SE, respectivamente;

- família 4 - estruturas de direção geral WNW-ESE, mergulhos altos para NE, e atitude média N100/80NE.

As fraturas da família 1 constituem prováveis juntas de alívio (Almeida \& Carneiro 1998). No Bloco Cotia, Hasui (1975) descreveu sistemas de fraturas sub-horizontais de origem tectônica, que apresentam maior distribuição e continuidade lateral. Em função do padrão de distribuição dessas estruturas, 
mais continuas e sistemáticas a maiores profundidades, e provável que, nas porções mais rasas, acima do topo rochoso, essas estruturas representem juntas de alívio de carga, com pequena continuidade lateral, enquanto que, em maiores profundidades, representem fraturas sistemáticas.

A família 2 corresponde às estruturas dos lineamentos N-S, do estudo de lineamentos morfoestruturais delineadas a partir da análise morfométrica (Anexo I, figuras 4 e 5), e também às estruturas de direção NNW-SSE identificadas na análise dos afloramentos rochosos (Capítulo 5). As atitudes destas fraturas indicam provável vínculo com o evento deformacional rúptil transcorrente dextral, de binário E-W, ativo no RCSB durante o Pleistoceno. Essas estruturas provavelmente possuem grande continuidade em profundidade, além de elevada probabilidade de encontrarem-se abertas, uma vez que podem ter sido reativadas em processos distensivos de orientação NW-SE a E-W do início do Holoceno. Nos afloramentos estas estruturas exibem grande continuidade e boa partição na rocha.

A família 3 abrange as estruturas com direção NE-SW identificadas na análise de lineamentos a partir da morfometria e também corresponde às famílias NE-SW da análise dos afloramentos rochosos (Capítulo 5). Essas fraturas foram geradas e/ou reativadas em diferentes eventos, com idades entre o Neoproterozóico e o Mioceno. Possuem provavelmente alta continuidade, independentemente da profundidade. Quando expostas em afloramentos, constituem famílias de alta densidade. Em alguns locais da área de estudos foram observadas relações de superposição desta família com as foliações regionais do embasamento.

A família 4 inclui as estruturas de direção WNW-ESE identificadas nos levantamentos de campo em afloramentos rochosos, bem como a partir de lineamentos extraídos de mapas morfométricos (Capítulo 5). Apresentam orientação favorável à abertura diante do campo de esforços atuais, de compressão E-W, de maneira que podem manifestar-se em maiores profundidades. 


\subsubsection{Estudos de densidade de fraturas}

As famílias e subfamílias tiveram suas densidades calculadas conjuntamente e para cada área de detalhe separadamente. As áreas de detalhe apresentaram valores diferentes para a mesma família, o que provavelmente reflete a variação das densidades em função das proximidades de grandes lineamentos. Esta afirmação baseia-se nos estudos de afloramentos e de sondagens, que apresentaram boa relação entre posição de lineamentos e freqüência de famílias de fraturas relacionadas ao lineamento (Anexo I, figuras 16 e 17).

Destaca-se a escassez de estruturas da família 4 (WNW-ESE) na área de detalhe $A$, o que provavelmente pode estar relacionado à ausência de lineamentos de direção $\mathrm{E}-\mathrm{W}$ nessa área. $\mathrm{Na}$ área de detalhe $\mathrm{B}$, onde ocorrem lineamentos com as orientações E-W, é possível observar fraturas da família 4 nos poços.

A baixa proporção de estruturas da família sub-horizontal (família 1) na área de detalhe $B$ reflete a importância dos furos inclinados na caracterização da área, uma vez que, na área de detalhe $A$, com poços verticais, a importância relativa da família horizontalizada foi maior.

A comparação dos valores de densidades ponderadas da família 1 (subhorizontal) nas duas áreas indicou a mesma ordem de grandeza. Enquanto que a comparação da proporção relativa da família 1 em cada área de detalhe apresenta valores distintos (31 e 5\%, respectivamente). Isso mostra que o maciço da área de detalhe $B$ é mais fraturado, porém as fraturas da família 1 mantêm a mesma densidade ponderada. Esta comparação corrobora com uma origem desta família devido à alívio de carga, que atingiu as rochas de ambas as áreas de maneira similar durante o evento de soerguimento.

Devido à correlação existente entre os lineamentos e famílias de juntas observadas em afloramentos com as fraturas identificadas nos poços, foi 
efetuada uma comparação entre mapa de densidade de lineamentos com as densidades de fraturas por metro perfurado nos poços.

$\mathrm{Na}$ área de detalhe $\mathrm{A}$, as densidades de lineamentos estiveram na classe de 0,0007 a $0,0020 \mathrm{~m} / \mathrm{m}^{2}$ e a densidade de fraturas por metro linear perfurado foi de 0,171 fraturas por metro linear, enquanto que na área de detalhe $B$ a densidade de lineamentos esteve na classe de 0,0033 a $0,0069 \mathrm{~m} / \mathrm{m}^{2}$ enquanto que a densidade de fraturas por metro linear perfurado foi de 0,563 fraturas por metro. $\mathrm{Na}$ comparação com as duas áreas de detalhe somadas, o valor médio foi de $0,0020 \mathrm{~m} / \mathrm{m}^{2}$ para os lineamentos e 0,262 fraturas por metro linear perfurado para as áreas de detalhe. Embora os valores obtidos para os dados de poços sejam duas ordens de grandeza superiores em relação aos valores obtidos a partir dos mapas de lineamentos, a correlação pode ser considerada excelente. A diferença está provavelmente relacionada ao fato de que uma densidade está expressa com denominador em unidades lineares (fraturas $/ \mathrm{m}$ ) e a outra densidade estar expressa com denominador em unidades de área $\left(\mathrm{m} / \mathrm{m}^{2}\right)$.

Como resultado, é possível correlacionar os valores de densidade de lineamentos por unidade de área $\left(\mathrm{m} / \mathrm{m}^{2}\right)$ com os valores de fraturas por metro linear perfurado.

Jesus (2005) verificou uma boa correlação entre a capacidade de produção e a transmissividade de poços em função da distância de lineamentos, quando esta distância é inferior a 200 m. O mapa de densidades de lineamentos (figura 11, anexo I) foi confeccionado interpolando células de $500 \times 500 \mathrm{~m} \mathrm{e}$ apresentou correlação muito boa com os estudos de detalhe, resultado ainda melhor do que os $200 \mathrm{~m}$ de distância de um lineamento (Jesus 2005). Isto indica que um refinamento da interpolação de mapas de densidade de lineamentos pode aproximar ainda mais os resultados da densidade de fraturas por metro (escala de detalhe) com os resultados de densidade de lineamentos por área (escala de semi-detalhe). 


\subsubsection{Correlação entre os resultados dos estudos da área de semi-detalhe nos estudos de detalhe}

A comparação dos resultados obtidos entre as escalas de estudo em 1:50.000 (semi-detalhe) e 1:5.000 (detalhe) permite afirmar que, no caso em estudo:

- $\quad$ existe a possibilidade de identificar e caracterizar famílias de estruturas presentes na área de detalhe, partindo do estudo de afloramentos;

- os lineamentos interpretados a partir do estudo morfométrico podem indicar a ocorrência de famílias de estruturas em um dado local nas proximidades do lineamento, e conseqüentemente locais distantes de lineamentos morfoestruturais tendem a apresentar ausência ou escassez de estruturas;

- de maneira qualitativa e semi-quantitativa os estudos morfométricos podem fornecer informações sobre a densidade de fraturamento das áreas de detalhe;

- $\quad$ os estudos regionais apresentam uma importante aplicação na definição da orientação das sondagens, se verticais ou inclinadas (quando ocorrem famílias sub-verticais), e quando inclinadas, quais os melhores rumos para a perfuração.

\subsection{Hidrogeologia no meio cristalino fraturado}

Os dados hidrogeológicos de condutividade hidráulica, cargas hidráulicas e conexões hidráulicas foram obtidos a partir dos poços de monitoramento instalados em sondagens na rocha, em geral com perfurações de 20 a 30 metros, chegando a 50 metros no PMR-09. Estas profundidades podem ser consideradas como pertencentes ao topo do aqüífero fraturado. 


\subsubsection{Análise do fluxo da água subterrânea e conexões entre fraturas do topo do aqüífero cristalino fraturado}

A área de detalhe $A$ apresenta uma superfície potenciométrica que aponta uma forte anisotropia N-S, mesma direção do lineamento traçado por anomalias das superfícies de base (Anexo I, figura 22). O fluxo ocorre de outros pontos da área para a região central próxima ao lineamento, para em seguida fluir para o norte, ao longo do lineamento, acompanhando a declividade topográfica, com gradiente hidráulico médio de $12,5 \%$.

A variação das cargas hidráulicas da área de detalhe $A$ em função das chuvas sugere uma conexão entre as fraturas de direção N-S e NE-SW (item 6.6), o que pode ser extrapolado para a escala dos lineamentos identificados na análise morfométrica, além de uma tendência de fluxo descendente na área.

As informações do ensaio de bombeamento e perfis de resistividade elétrica da área de detalhe $\mathrm{A}$, comparados com as informações estruturais, apontaram que:

- o PP-01 está fortemente conectado com as estruturas do aqüífero fraturado na porção norte da área (PMR-02 e 03), provavelmente por meio das fraturas de direção NE-SW (família 3);

- as estruturas do aqüífero fraturado na área dos poços PMR-01B e 06 estão moderadamente conectadas com o PP-01, provavelmente por meio de conexão de estruturas N-S (família 2), ligando os poços PMR-01B e 06 com as estruturas NE-SW (família 3) em direção ao PP-01, o que mostra importante conexão entre as famílias 2 e 3;

- o PP-01 está fracamente conectado com as estruturas do aqüífero fraturado no centro da área (PMR-07), o que indica que é provável que o fluxo ocorra por meio de zonas mais fraturadas, que não são uniformemente distribuídas na área;

- as estruturas do PP-01 não apresentam conexão com as estruturas dos PMR-04 e 05, onde os níveis de água subiram devido à recarga natural (o teste foi realizado durante a estação de chuvas). 
Em geral, na área $A$ ocorrem sistemas de fraturas de mergulho médio a sub-vertical das famílias 2 e 3, que geram anisotropias na direções N-S e NE$\mathrm{SW}$, respectivamente. As fraturas sub-horizontais da família 1 promovem uma maior conexão entre as estruturas da área, conectando os sistemas de fraturas de mergulhos moderados e sub-verticais. Desta maneira é facilitado o fluxo da água subterrânea para as estruturas relacionadas ao lineamento principal N-S, que representa forte anisotropia do fluxo nesta direção. A velocidade do fluxo da água de sul para norte é influenciada pela declividade no sentido do fluxo.

A área B está localizada na planície de alagamento do rio Cotia, que nesta porção da área de estudos é condicionado por lineamentos de direção N-S (família 2). O rio é considerado o ponto de descarga do aqüífero, uma vez que regionalmente este é o principal rio da área. Esta conclusão é sustentada pelos valores das cargas hidráulicas dos poços PMR-14 A e B, que apresentam fluxo ascendente de $9 \%$.

O fluxo da água subterrânea na área B apresenta evidente controle estrutural, uma vez que cargas hidráulicas dos poços PMR-12, 14, 14B e 15 não exibem um controle topográfico, como seria esperado, e assim são maiores do que as cargas da região central (PMR-13). Desta maneira é provável que o fluxo da água subterrânea ocorra em direção às estruturas interceptadas pelo PMR13 , e estas estruturas se conectem com aquelas que condicionam o segmento do rio Cotia.

\subsubsection{Condutividade hidráulica dos poços do topo do aqüífero fraturado}

Em geral, o fluxo da água subterrânea foi considerado como do tipo radial e regido pelas leis de Darcy. Diante disso, as estimativas de condutividade hidráulica $(K)$ foram realizadas por meio de ensaio de recuperação e solução matemática, com uso do método de Hvorslev (1951). Um fator limitante à aplicação de solução matemática para fluxo poroso em meio fraturado seria a presença de fraturas preenchidas com materiais de permeabilidade variável 
(Barker \& Black 1983). Nos levantamentos de detalhe não foram encontrados preenchimentos com tais características.

As condutividades hidráulicas variaram de $1,55 \times 10^{-8}$ a $2 \times 10^{-5} \mathrm{~cm} / \mathrm{s}$, com

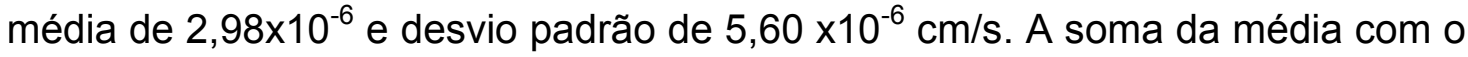
desvio padrão apresenta valores anômalos para condutividades maiores do que $8,66 \times 10^{-6} \mathrm{~cm} / \mathrm{s}$. Com base nesta análise estatística, algumas fraturas interceptadas pelos poços PMR-14A e 15, e talvez pelo PMR-03, possuem valores de condutividade hidráulica anômalos, podendo apresentar fluxo do tipo linear, ou não regido pela lei de Darcy.

Nos três poços supracitados foram detectados fraturas de todas as famílias, mas com maior freqüência de estruturas das famílias 1 e 3B. Adicionalmente, foi constatado que as sondagens PMR-14 e 15 apresentam dois dos maiores valores de densidade linear e ponderada de fraturas por metro da área.

\subsubsection{Abertura das fraturas e relação com a condutividade hidráulica}

A condutividade hidráulica $(K)$ em meios cristalinos fraturados pode ser atribuída unicamente à permeabilidade secundária. Assim, o valor de $\mathrm{K}$ é definido com base na somatória da abertura das fraturas interceptadas pela seção filtrante do poço. Com base nos valores de $\mathrm{K}$ (estimados com uso de ensaios de recuperação) foi calculada a abertura total de cada seção filtrante, usando as equações 3.1 e 3.2 (capítulo 3) da "lei cúbica" (Snow 1969).

Para o cálculo da equação 3.1 foram usados como densidade de fratura os valores de densidades lineares e ponderadas apresentadas na tabela 6.1. No emprego da equação 3.2, que utiliza a transmissividade $(T)$ nos cálculos das somatórias da abertura das fraturas, a transmissividade foi calculada a partir da razão dos valores de condutividade hidráulica estimados para os poços e o comprimento da seção filtrante (espaço preenchido por pré-filtro nos poços) de cada poço. A abertura individual das fraturas foi calculada pelo quociente da somatória estimada das aberturas dividido pelo número de fraturas no intervalo. 
O estudo estatístico das aberturas calculadas é apresentado na tabela 7.1. Os resultados mostram que a abertura média de cada fratura é de $1,13 \times 10^{-3}$ $\mathrm{cm}$, variando entre $2,78 \times 10^{-4}$ e $1,99 \times 10^{-3} \mathrm{~cm}$. Estes resultados foram usados para calcular a condutividade hidráulica do meio fraturado, usando os valores de densidade média linear e ponderada de fraturas. A condutividade hidráulica média ficou entre $3,35 \times 10^{-5}$ e $6,28 \times 10^{-5} \mathrm{~cm} / \mathrm{s}$, com valores variando normalmente entre $4,99 \times 10^{-7}$ e $3,39 \times 10^{-4} \mathrm{~cm} / \mathrm{s}$.

\begin{tabular}{|c|c|c|c|c|c|c|c|}
\hline & 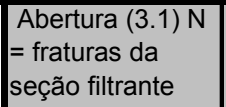 & $\begin{array}{l}\text { Abertura (3.1) } \\
\mathrm{N}=\text { densidade } \\
\text { linear }\end{array}$ & $\begin{array}{l}\text { Abertura (3.1) } \\
\mathrm{N}=\text { densidade } \\
\text { ponderada }\end{array}$ & $\begin{array}{l}\text { Abertura (3.2) } \\
\mathrm{T}=\mathrm{K} / \text { seção } \\
\text { filtrante }\end{array}$ & $\begin{array}{l}\text { Abertura } \\
\text { indivudual } \\
\text { média }(\mathrm{cm})\end{array}$ & \begin{tabular}{|l|}
$\mathrm{K}$ do Meio \\
Frat. $(\mathrm{cm} / \mathrm{s})$ \\
$\mathrm{N}$ linear
\end{tabular} & $\begin{array}{l}\text { K do Meio } \\
\text { Frat.(cm/s) } \\
\text { Npond. }\end{array}$ \\
\hline Média & 2,44E-03 & 3,13E-03 & $3,52 \mathrm{E}-03$ & 6,63E-04 & $2,44 \mathrm{E}-03$ & $3,35 \mathrm{E}-05$ & $6,28 \mathrm{E}-05$ \\
\hline Mínimo & $6,41 \mathrm{E}-04$ & 8,99E-04 & $8,99 \mathrm{E}-04$ & $1,10 \mathrm{E}-04$ & $1,10 \mathrm{E}-04$ & $3,04 \mathrm{E}-09$ & $5,69 \mathrm{E}-09$ \\
\hline Máximo & $6,48 \mathrm{E}-03$ & 6,94E-03 & $9,75 \mathrm{E}-03$ & $2,26 \mathrm{E}-03$ & $9,75 \mathrm{E}-03$ & $2,14 \mathrm{E}-03$ & $4,01 \mathrm{E}-03$ \\
\hline $\begin{array}{l}\text { Desvio } \\
\text { Padrão }\end{array}$ & $1,84 \mathrm{E}-03$ & $2,12 \mathrm{E}-03$ & $2,76 \mathrm{E}-03$ & $6,40 \mathrm{E}-04$ & 1,84E-03 & $1,44 \mathrm{E}-05$ & 2,69E-05 \\
\hline $\begin{array}{l}\text { Média - } \\
\text { Desv. Padr. } \\
\end{array}$ & $6,04 \mathrm{E}-04$ & $1,01 \mathrm{E}-03$ & 7,61E-04 & $2,32 \mathrm{E}-05$ & $6,00 \mathrm{E}-04$ & 4,99E-07 & $9,35 \mathrm{E}-07$ \\
\hline $\begin{array}{l}\text { Média + } \\
\text { Desv. Padr. }\end{array}$ & $4,28 \mathrm{E}-03$ & $5,24 \mathrm{E}-03$ & $6,28 \mathrm{E}-03$ & $1,30 \mathrm{E}-03$ & $4,28 \mathrm{E}-03$ & 1,81E-04 & $3,39 \mathrm{E}-04$ \\
\hline
\end{tabular}

Tabela 7.1 - Estudo estatístico das aberturas das fraturas e condutividade hidráulica resultante.

A partir da abordagem de aberturas médias das fraturas, pode-se estimar aberturas de fraturas separadas por famílias. Com base nos dados de $\mathrm{K}$ estimados (exceto para os poços PMR-14 A e 15, considerados anômalos) e dos dados de presença de fraturas abertas nas seções filtrantes, foram calculadas as somatórias das aberturas das fraturas, a partir de um sistema de 7 equações com 4 incógnitas (tabela 7.2).

Os cálculos foram realizados sob a condição de todos os resultados serem sempre positivos, uma vez que são medidas de abertura. Os resultados das famílias 1, 2 e 3 foram obtidos diretamente de equações do tipo "ax=b" ("a" é número de fraturas, " $x$ " é a incógnita e "b" corresponde à somatória das aberturas do poço) Estes valores foram fixados nas equações de mais de uma incógnita com intuito de testar os resultados e de estimar valores para as fraturas da família 4 . Os valores para a família 4 (b F4) foram obtidos de uma 
média dos resultados observados. Para a equação do PMR-6 foi fixado o valor da abertura da família 3 - uma vez que, quando fixado para a família 2, o resultado da família 3 foi um número negativo - e novamente o valor médio foi considerado como a abertura média da família.

\begin{tabular}{|c|c|c|c|c|c|c|c|c|c|}
\hline & $\begin{array}{c}\text { Abertura total } \\
\text { média }\end{array}$ & $\begin{array}{c}F 1 \\
\text { fraturas }\end{array}$ & $\begin{array}{c}\text { F2 } \\
\text { fraturas }\end{array}$ & $\begin{array}{c}\text { F3 } \\
\text { fraturas }\end{array}$ & $\begin{array}{c}\mathrm{F} 4 \\
\text { fraturas }\end{array}$ & $\begin{array}{l}\text { b F1 } \\
(\mathrm{cm})\end{array}$ & $\begin{array}{l}\text { b F2 } \\
(\mathrm{cm})\end{array}$ & $\begin{array}{l}\text { b F3 } \\
(\mathrm{cm})\end{array}$ & $\begin{array}{l}\text { b F4 } \\
(\mathrm{cm})\end{array}$ \\
\hline PMR 1 e 3 & 1,09E-02 & 5 & 0 & 0 & & $2,18 \mathrm{E}-03$ & - & - & - \\
\hline PMR-2 & $7,75 \mathrm{E}-03$ & 3 & 0 & 0 & 2 & $2,18 \mathrm{E}-03$ & - & - & 6,05E-04 \\
\hline PMR-4 & $4,95 \mathrm{E}-03$ & 0 & 1 & 0 & 0 & - & $4,95 \mathrm{E}-03$ & - & - \\
\hline PMR-5, 7 e 12 & $1,03 \mathrm{E}-02$ & 0 & 0 & 8 & 0 & - & - & $1,29 \mathrm{E}-03$ & - \\
\hline PMR-6 & $3,48 \mathrm{E}-03$ & 0 & 4 & 1 & 0 & - & 5,48E-04 & $1,29 \mathrm{E}-03$ & - \\
\hline PMR-13 & $9,38 \mathrm{E}-03$ & 0 & 0 & 5 & 3 & - & - & 1,29E-03 & 9,84E-04 \\
\hline PMR-14 B & $1,48 \mathrm{E}-02$ & 0 & 0 & 7 & 1 & - & - & 1,29E-03 & $5,84 \mathrm{E}-03$ \\
\hline Total Médio & $2,44 \mathrm{E}-03$ & - & - & - & - & $2,18 \mathrm{E}-03$ & $2,75 \mathrm{E}-03$ & 1,29E-03 & $2,47 \mathrm{E}-03$ \\
\hline Dens. Linear & $2,52 \mathrm{E}-03$ & & & & & $6,77 \mathrm{E}-04$ & $2,57 \mathrm{E}-04$ & $4,74 \mathrm{E}-04$ & $3,79 \mathrm{E}-04$ \\
\hline $\begin{array}{c}\text { K médio do meio } \\
\text { fraturado } \\
\text { dens.linear }\end{array}$ & $3,36 \mathrm{E}-07$ & - & - & - & - & $6,43 \mathrm{E}-08$ & 1,29E-07 & $1,32 \mathrm{E}-08$ & $9,41 \mathrm{E}-08$ \\
\hline Dens. Ponder. & $4,72 \mathrm{E}-03$ & & & & & 7,77E-04 & $6,62 \mathrm{E}-04$ & 7,97E-04 & 1,02E-03 \\
\hline $\begin{array}{c}\text { K médio do meio } \\
\text { fraturado } \\
\text { dens.pond. }\end{array}$ & $6,29 \mathrm{E}-07$ & - & - & - & - & $7,39 \mathrm{E}-08$ & $1,48 \mathrm{E}-07$ & $1,52 \mathrm{E}-08$ & $1,08 \mathrm{E}-07$ \\
\hline
\end{tabular}

Tabela 7.2 - Abertura de fraturas, densidade de fraturamento linear e ponderada, e condutividade hidráulica por família (as células em amarelo foram fixadas nas equações).

É importante salientar que estes valores foram calculados com base na população de dados disponível para o estudo. Levando-se em conta os erros carregados dos métodos de investigação aplicados, os valores de abertura das fraturas podem ser maiores ou menores, conforme as técnicas disponíveis para as estimativas.

Das técnicas utilizadas duas se destacam como prováveis fontes de incerteza. A primeira é o ensaio de recuperação e a solução matemática empregada para o cálculo de K. A segunda incerteza diz respeito à interpretação da perfilagem acústica (BHTV) para separação das fraturas abertas e fechadas. 


\subsubsection{Estimativa de condutividade hidráulica a partir da análise do}

\section{fraturamento das áreas de estudos de detalhe}

Com base nos valores de abertura de fratura por família e dos dados de densidade de fraturas foi possível calcular a condutividade hidráulica do meio fraturado, por meio das famílias estruturais. Desta maneira, a partir de uma orientação e de um comprimento de seção filtrante conhecidos pode-se prever o número de fraturas de cada família que o poço interceptará e, com base nas estruturas, simular a condutividade hidráulica de um poço.

A abertura total das fraturas da seção filtrante do poço é calculada pela equação abaixo:

$$
\begin{aligned}
& \sum b=\sum_{n \cdot f a m} \text { Filtro } \times \cos \theta \cdot f a m \cdot n \times N \cdot f a m \cdot n \times b \cdot f a m \cdot n \\
& \text { Onde: } \\
& \sum_{\text {Filtro }=\text { Comprimento da seção filtrante na rocha fraturada }} b=\text { Somatória da abertura das fraturas de uma secão filtrante } \\
& \text { Cos } \theta \text { fam } \mathrm{n}=\text { Cosseno da abertura angular das atitudes do poço e do pólo da família } \mathrm{n} \\
& \mathrm{N} \text { fam } \mathrm{n}=\text { Densidade da família } \mathrm{n} \\
& \mathrm{b} \text { fam } \mathrm{n}=\text { Abertura média da família } \mathrm{n}
\end{aligned}
$$

Com a somatória das aberturas das fraturas pode-se calcular a transmissividade $\mathrm{T}$ de um poço de comprimento e atitude conhecido, empregando-se a equação 3.2, da lei cúbica de Snow (1969).

Os poços PP-01 e PMR-11 não foram utilizados para o cálculo das densidades e abertura das fraturas. Para estes poços foram obtidos valores de condutividade hidráulica $(\mathrm{K})$ e transmissividade $(\mathrm{T})$ com uso de ensaio de bombeamento, que apresenta soluções matemáticas com menores incertezas para $\mathrm{K}$ e $\mathrm{T}$. Os valores de $\mathrm{K}$ e $\mathrm{T}$ dos ensaios hidráulicos e dos obtidos a partir do cálculo proposto, com valores de densidade linear e ponderado, são apresentados na tabela 7.3 . 


\begin{tabular}{|c|c|c|c|c||}
\hline $\begin{array}{c}\mathrm{T} \\
\left(\mathrm{cm}^{2} / \mathrm{s}\right)\end{array}$ & $\begin{array}{c}\text { Comprimento } \\
\text { seção } \\
\text { filtrante }(\mathrm{m})\end{array}$ & $\begin{array}{c}\text { Ensaio } \\
\text { hidráulico }\end{array}$ & $\begin{array}{c}\text { Densidade } \\
\text { linear }\end{array}$ & $\begin{array}{c}\text { Densidade } \\
\text { ponderada }\end{array}$ \\
\hline $\mathrm{PP}-01$ & 260 & $1,33 \mathrm{E}+01$ & $2,76 \mathrm{E}+01$ & $5,53 \mathrm{E}+01$ \\
\hline $\mathrm{PMR}-11$ & 40 & $1,44 \mathrm{E}-01$ & $1,01 \mathrm{E}-01$ & $2,01 \mathrm{E}-01$ \\
\hline $\begin{array}{c}\mathrm{K} \\
(\mathrm{cm} / \mathrm{s})\end{array}$ & $\begin{array}{c}\text { Comprimento } \\
\text { seção } \\
\text { filtrante }(\mathrm{m})\end{array}$ & $\begin{array}{c}\text { Ensaio } \\
\text { hidráulico }\end{array}$ & $\begin{array}{c}\text { Densidade } \\
\text { linear }\end{array}$ & $\begin{array}{c}\text { Densidade } \\
\text { ponderada }\end{array}$ \\
\hline $\mathrm{PP}-01$ & 260 & $1,66 \mathrm{E}-03$ & $1,06 \mathrm{E}-03$ & $2,13 \mathrm{E}-03$ \\
\hline PMR-11 & 40 & $7,23 \mathrm{E}-05$ & $2,51 \mathrm{E}-05$ & $5,03 \mathrm{E}-05$ \\
\hline
\end{tabular}

Tabela 7.3 - Comparação de condutividade hidráulica e transmissividade calculadas.

Os resultados foram satisfatórios para os poços, uma vez que variaram menos de uma ordem de grandeza. Vale ressaltar que o comprimento da seção filtrante influencia as estimativas, pois com o aumento do comprimento a população amostral tende a se tornar mais próxima da realidade. O método foi aplicado nos poços de monitoramento com filtro instalado (em geral com 5 metros de seção) e apenas $58 \%$ dos poços mostraram variação inferior a uma ordem de grandeza entre o $\mathrm{K}$ calculado e o obtido por meio de ensaios.

\subsubsection{Estimativa de condutividade hidráulica e transmissividade a partir da análise do fraturamento da escala de semi-detalhe}

Nas áreas de estudos de detalhe foi possível efetuar uma estimativa do valor de transmissividade e condutividade hidráulica de um poço de atitude e comprimento de seção filtrante conhecido. Para tanto foi necessário identificar as fraturas nos poços, separá-las em famílias, determinar a densidade de fraturas por família, bem como medir os valores de condutividade dos poços. Um dos fatores essenciais para que este resultado fosse alcançado é o fato da área de estudo apresentar forte controle estrutural nas propriedades hidrogeológicas do aqüífero cristalino fraturado.

Neste estudo foi verificada excelente correlação entre a densidade de lineamentos (obtida a partir da análise morfométrica em escala de semi-detalhe) e a densidade linear de fraturas (a partir de dados de perfilagem acústica de poços). Este fato, somado à possibilidade de se medir a abertura média de fraturas com base na observação de afloramentos ou dados de poços, torna 
possível a estimativa da condutividade hidráulica e transmissividade de um poço em função da sua atitude e comprimento da seção filtrante.

O método proposto compreende as seguintes etapas:

- $\quad$ caracterização das famílias de estruturas em escala de semi-detalhe a partir de estudos de afloramentos e correlações com o estudo morfométrico;

- $\quad$ elaboração e decomposição do mapa de lineamentos de sombreamento de relevo nas direções das estruturas classificadas em famílias direcionais (nesta etapa é desprezado o ângulo de mergulho das estruturas);

- gerar os mapas de densidade de lineamentos (células de $200 \mathrm{~m}$ ) para cada família definida por variação angular de azimute;

- $\quad$ aplicar a equação 7.1 para o cálculo das células (ou de um dado ponto), com uso do valor da densidade de lineamentos multiplicado por 100 no lugar da densidade de fraturamento;

- $\quad$ se houver mais de uma família com a mesma direção, os valores de densidade de lineamentos para esta direção devem ser distribuídos de forma ponderada de acordo com o número de fraturas de cada família no estudo de campo; como exemplo, no caso de haver 20 fraturas de uma família N-S com mergulho alto para E e 30 fraturas de uma família N-S com mergulho médio para $W$, deve-se distribuir o valor da densidade em 40 e $60 \%$, respectivamente;

Novamente, a partir da somatória das aberturas das fraturas, pode-se calcular a transmissividade $(\mathrm{T})$ de um poço de comprimento e atitude conhecido, com uso da equação 3.2 da lei cúbica de Snow (1969),

O método não permite calcular a abertura das fraturas sub-horizontais a horizontais. Como essas estruturas não possuem expressão morfológica, não é possível obter um valor de densidade de lineamentos para uma família com essa atitude. 
No caso em estudo, no qual admite-se que as famílias de estruturas subhorizontais a horizontais foram originadas por alívio de carga, a densidade de fraturas da família 1 variou entre 0,039 a 0,075 fraturas/metro na densidade linear e 0,058 a 0,081 fraturas/metro na densidade ponderada. Desta maneira, admitindo-se que uma área apresente o mesmo mecanismo de alívio de carga, é possível utilizar um valor para esta densidade de fratura horizontal para a região, sendo necessário um levantamento de campo, com técnicas apropriadas para obtenção de uma densidade adequada. Os valores de densidade de fraturas horizontais da área de detalhe foram usados para a estimativa regional.

Os valores de T e K dos ensaios hidráulicos dos poços PP-01 e PMR-11 novamente foram utilizados para comparar os resultados obtidos a partir do cálculo proposto. Os mapas densidades de lineamentos separados por classes azimutais (classes de direção N-S, NE-SW, NW-SE e E-W) são apresentados nas figuras 23 a 26 do anexo I. Os valores de densidade de lineamentos foram obtidos dos mapas de lineamentos direcionais, com interpolação de células de $200 \mathrm{~m}$ (10 classes de densidade), e o valor de densidade utilizado foi o valor médio da classe em que os poços a serem estimados se encontram. Os valores de $\mathrm{T}$ e $\mathrm{K}$ simulados comparados aos obtidos por ensaio hidráulico são apresentados na tabela 7.4.

\begin{tabular}{|c|c|c|c|c|}
\hline \multirow{2}{*}{$\begin{array}{c}\mathrm{T} \\
\left(\mathrm{cm}^{2} / \mathrm{s}\right)\end{array}$} & \multirow{2}{*}{$\begin{array}{l}\text { Comprimento } \\
\text { seção filtrante } \\
\text { (m) }\end{array}$} & \multicolumn{2}{|c|}{ Método } & \multirow[b]{2}{*}{$\mathrm{T} / \mathrm{T}$ real $(\%)$} \\
\hline & & $\begin{array}{c}\text { Ensaio } \\
\text { hidráulico }\end{array}$ & $\begin{array}{c}\text { Densidade } \\
\text { lineamentos }\end{array}$ & \\
\hline PP-01 & 260 & $1,33 E+01$ & $1,87 \mathrm{E}+01$ & 141 \\
\hline PMR-11 & 40 & 1,44E-01 & $6,79 \mathrm{E}-02$ & 47 \\
\hline $\mathrm{K}(\mathrm{cm} / \mathrm{s})$ & $\begin{array}{l}\text { Comprimento } \\
\text { seção filtrante } \\
\text { (m) }\end{array}$ & $\begin{array}{c}\text { Ensaio } \\
\text { hidráulico }\end{array}$ & $\begin{array}{c}\text { Densidade } \\
\text { lineamentos }\end{array}$ & $\mathrm{K} / \mathrm{K}$ real $(\%)$ \\
\hline PP-01 & 260 & 1,66E-03 & 7,17E-04 & 43 \\
\hline PMR-11 & 40 & $7,23 \mathrm{E}-05$ & 1,70E-05 & 24 \\
\hline
\end{tabular}

Tabela 7.4 - Comparação de condutividade hidráulica e transmissividade calculadas a partir do estudo de semi-detalhe. 
Os valores exibidos apresentam variações menores do que uma ordem de grandeza. Considerando-se $100 \%$ o valor ideal, este variou entre 47 a $141 \%$ para a transmissividade e entre 24 a $43 \%$ para o $\mathrm{K}$. Na escala de trabalho de semi-detalhe este erro é comumente aceitável, uma vez que erros menores do que uma ordem de grandeza são usualmente admitidos para estimativas de condutividade hidráulica em poços em aqüífero fraturado (Barker \& Black 1983). 


\section{CONCLUSÕES}

Os estudos do aqüífero fraturado na região de Cotia, SP, foram desenvolvidos em duas escalas de trabalho. A primeira de semi-detalhe, em 1:50.000, e a segunda de detalhe, em 1:5.000, esta última em duas porções distintas dentro da área de semi-detalhe. Os resultados obtidos em escala de semi-detalhe, a partir da análise da tectônica rúptil (morfometria, fotogeologia e levantamentos de campo), serviram para direcionar as investigações em escala de detalhe, onde foram usados dados provenientes de sondagens, métodos BHTV (Bore Hole Television), levantamento de perfis de eletrorresistividade e dados hidrogeológicos de poços de monitoramento instalados no aqüífero em meio fraturado.

Os estudos de escala de semi-detalhe permitiram delinear lineamentos de direções N-S, E-W, NE-SW e NW-SE, originados em diferentes fases de deformação rúptil. Esses dados de lineamentos foram correlacionados com dados de atitude de falhas e juntas medidas em afloramento, e, posteriormente, associados às diferentes fases de deformação descritas para o Rift Continental do Sudeste do Brasil. Foram definidas seis famílias de juntas: a) família NNWSSE, com mergulho alto para NE); b) família NE-SW com mergulho sub-vertical; c) família E-W com mergulho alto para NW); d) família WNW-ESE com mergulho alto para NE); e) família NE-SW com mergulho médio para NW; e f) família NESW com mergulho médio para SE.

Um grupo de juntas apresentou padrão de cisalhamento com ângulo $2 \theta$ maior do que $50^{\circ}$, e padrão híbrido com ângulo $2 \theta$ entre 10 e $50^{\circ}$. Foram obtidos direções de SHmáx NW-SE e Shmín NE-SW. Esta configuração se assemelha com as direções de encurtamento e distensão observadas nas falhas, as quais foram interpretadas pelo método dos diedros retos.

Também foram observadas juntas de cisalhamento das famílias de direção NE-SW e WNW-ESE, que podem ter sido originadas sob um campo de esforços compressivo NE-SW, talvez relacionado à transcorrência sinistral com 
binário E-W, ativa regionalmente por duas vezes durante o Neocretáceo e o Neógeno (Riccomini et al. 2004).

Os lineamentos de direção N-S e E-W foram aparentemente ativos na mesma escala de tempo. As famílias de juntas NNW-SSE e WNW-ESE apresentam direções muito aproximadas àquelas dos lineamentos. Estas famílias foram originadas sob campo de esforços com compressão de direção NW-SE e distensão NE-SW, do evento de transcorrência dextral (idade atribuída regionalmente ao Pleistoceno). $\mathrm{E}$ alguns lineamentos $\mathrm{E}-\mathrm{W}$ podem relacionar-se às estruturas neoproterozóicas das zonas de cisalhamento.

Os resultados dos estudos desenvolvidos em escala de semi-detalhe, somados aos condicionantes geológicos e geomorfológicos das áreas selecionadas para estudos de detalhe, orientaram a instalação de poços de monitoramento verticais e inclinados nessas últimas. Foram instalados 11 poços na área de detalhe $\mathrm{A}$ e quatro poços na área de detalhe $\mathrm{B}$. Os poços foram perfilados por televisionamento acústico e as fraturas identificadas nesses poços foram separadas por famílias e subfamílias: Família 1 (sub-horizontal), Família 2A (N-S com mergulho médio para $\mathrm{W}$ ) e 2B (N-S com mergulho alto para $E$ ), Família 3A (NE-SW com mergulho médio para NW) e 3B (NE-SW com mergulho médio para SE) e Família 4 (WNW-ESE sub-vertical).

$\mathrm{Na}$ área de detalhe $\mathrm{A}$, as densidades de lineamentos estiveram na classe de 0,0007 a $0,0020 \mathrm{~m} / \mathrm{m}^{2}$ e a densidade de fraturas por metro linear perfurado foi de 0,171 fraturas por metro linear, enquanto que na área de detalhe $\mathrm{B}$ a densidade de lineamentos esteve na classe de 0,0033 a $0,0069 \mathrm{~m} / \mathrm{m}^{2}$, enquanto que a densidade de fraturas por metro linear perfurado foi de 0,563 fraturas por metro. $\mathrm{Na}$ comparação com as duas áreas de detalhe somadas, o valor médio foi de $0,0020 \mathrm{~m} / \mathrm{m}^{2}$ para os lineamentos e 0,262 fraturas por metro linear perfurado para as áreas de detalhe.

$\mathrm{Na}$ maioria dos poços foram realizados ensaios hidráulicos para determinação da condutividade hidráulica $(K)$, que variou de $1,55 \times 10^{-8}$ a $2 \times 10^{-5}$ $\mathrm{cm} / \mathrm{s}$, com média de $2,98 \times 10^{-6}$ e desvio padrão de $5,60 \times 10^{-6} \mathrm{~cm} / \mathrm{s}$. Ensaios de 
bombeamento indicaram fluxo de água subterrânea através das estruturas N-S, com boa conexão com as estruturas NE-SW.

A abertura média das fraturas foi de $1,13 \times 10^{-3} \mathrm{~cm}$, calculada com base nos valores de condutividade hidráulica correlacionados aos dados estruturais. Também foi calculada a abertura média por família, que variou de $1,29 \times 10^{-3} \mathrm{~cm}$ a $2,75 \times 10^{-3} \mathrm{~cm}$. O valor médio de abertura, nesse caso, não foi calculado a partir dos valores de abertura de cada família, e sim com base em todas as estruturas e poços dos estudos de detalhe, enquanto que para a definição das aberturas por família optou-se por excluir dos cálculos valores de condutividade hidráulica anômalos e, por fim, utilizar os valores de densidade de fraturas/metro definidos no estudo de densidade de fraturas dos maciços.

Verificou-se, no caso em estudo, excelente correlação entre a densidade de lineamentos obtida a partir da análise morfométrica em escala de semidetalhe e a densidade linear de fraturas a partir de dados de perfilagem acústica de poços). Este fato, aliado à possibilidade de se medir a abertura média de fraturas com base na observação de afloramentos ou dados de poços, abrem a perspectiva de se poder estimar a condutividade hidráulica e transmissividade de um poço em função da sua atitude e comprimento da seção filtrante. Para esta finalidade, é proposto um procedimento metodológico com base nos resultados alcançados com o desenvolvimento do presente trabalho. 


\section{REFERÊNCIAS BIBLIOGRÁFICAS}

Almeida, F.F.M. 1964. Fundamentos geológicos do relevo paulista. Boletim do Instituto Geográfico e Geológico, 41:169-263.

Almeida, F.F.M. 1969. Diferenciação tectônica da Plataforma Brasileira. In: SBG, Congresso Brasileiro de Geologia, 23, Salvador, Anais, Salvador, SBG, p. 24-46.

Almeida, F.F.M. \& Carneiro, C.D.R. 1998. Origem e evolução da Serra do Mar. Revista Brasileira de Geociências, 28:135-150.

Alves, F.M. 2005. Tectônica rúptil do Maciço Alcalino de Poços de Caldas no contexto do Alinhamento Magmático de Cabo Frio. Monografia de trabalho de formatura, Instituto de Geociências, Universidade de São Paulo, São Paulo, 48 p.

Angelier, J. 1984. Tectonic analysis of fault slip data sets. Journal of Geophysical Research, 89:5835-5848.

Angelier, J. 1994. Fault slip analysis and palaeostress reconstruction. In: Hancock, P. L. (ed.) Continental Deformation. Oxford, Pergamon Press, p.53-100.

Angelier, J. \& Mechler, P. 1977. Sur une méthode graphique de recherché des contraints principales également utilisable en tectonique et en séismologie: La méthode des dièdres droits. Bulletin de la Société Geólogique de France, 7:13091318.

Aragaki, S. \& Mantovani, W. 1998. Caracterização do clima e da vegetação de remanescente florestal no planalto paulistano (SP). In: Aciesp, Simpósio de Ecossistemas Brasileiros, 4, Águas de Lindóia, Anais, Águas de Lindóia, Aciesp, 2:25-36

Asmus, H.E. \& Guazelli, M. 1981. Descrição sumária das estruturas da margem continental brasileira e das áreas oceânicas e continentais adjacentes, hipóteses sobre o tectonismo causador e implicações para os prognósticos de recursos minerais. In: PETROBRÁS, Estruturas e tectonismo da margem continental brasileira, e suas implicações nos processos sedimentares e na avaliação do potencial de recursos minerais, relatório final, Rio de Janeiro, CENPES/DINTEP. $p$. 187-269. (Projeto REMAC 9).

Barker, J.A. \& Black, J. H. 1983. Slug tests in fissured aquifers. Water Resources Research, 6:1558-1564.

Bouwer, H. \& Rice, R.C. 1976. A slug test for determining hydraulic conductivity of unconfined aquifers with completely or partially penetrating wells. Water Resources Research, 3:423-428.

Chiessi, C.M. 2004. Tectônica cenozóica do Maciço Alcalino de Passa Quatro (SP-MG$R J)$. Dissertação de mestrado, Instituto de Geociências, Universidade de São Paulo, São Paulo, 116p.

Cho, H. J.; Fiacco, R. J.; Daly, M. H. 2004. Pumping test analysis in a fractured crystalline bedrock. In: U.S. EPA/NGWA, Fractured Rock Conference: State of the Science and Measuring Success in Remediation, Portland, Atas, Portland, U.S. EPA/NGWA, p. 161-172.

Coblentz, D.D. \& Richardson, R.M. 1996. Analysis of the South American intraplate stress field. Journal Geophysics Research, 101:8643-8657. 
Cooper, H.H. \& Jacob, C.E. 1946. A generalized graphical method for evaluating formation constants and summarizing well field history. American Geophysical Union Transactions, 27:526-534.

Cooper, H.H.; Bredehoeft, J.D.; Papadopulos, S.S. 1967. Response of a finite-diameter well to an instantaneous charge of water. Water Resources Research, 3:263-269.

Cordani, U.G. \& Bittencourt, I. 1967. Determinações de idades potássio-argônio em rochas do Grupo Açungui. In: SBG, Congresso Brasileiro de Geologia, 21, Curitiba, Anais, Curitiba, SBG, p.218-233.

Cordani, U.G. \& Kawashita, K. 1971. Estudo geocronológico pelo método Rb-Sr de rochas graníticas intrusivas no Grupo Açungui. In: SBG, Congresso Brasileiro de Geologia, 25, São Paulo, Anais, São Paulo, SBG, p.105-110.

Cordani, U. G.; Milani, E. J., Thomaz Filho, A.; Campos, D. A. 2000. Tectonic Evolution of South America. Rio de Janeiro, 31st International Geological Congress, 854 p.

Costa, W.D. 1986. Análise dos fatores que atuam no aqüífero fissural - área piloto dos Estados da Paraíba e Rio Grande do Norte. São Paulo. Tese de doutoramento, Instituto de Geociências, Universidade de São Paulo, São Paulo, 205 p.

Coutinho, J.M.V. 1972. Petrologia do Precambriano em São Paulo e arredores. Boletim do Instituto de Geociências, 3:5-99.

CPRM - Companhia de Pesquisa de Recursos Minerais. 1999. Carta geológica da Folha São Paulo, escala 1:250.000.

Day, M.J. 1979. Surface roughness as a discriminator of tropical karst styles. Zeitschrift für Geomorphologie Supplement, 32:1-8.

Domenico, P. A. \& Schwartz, F. W. 1990. Physical and chemical hydrogeology. New York, John Wiley, $824 \mathrm{p}$.

Dunne, W.M. \& Hancock, P.L. 1994. Palaeostress analysis of small-scale brittle structures. In: Hancock, P.L. (ed.) Continental Deformation. Oxford, Pergamon Press, p.101-120.

Eddy, W.F. 1977. A new convex hull algorithm for planar sets. ACM Transactions on. Mathematical Software, 3:398-403.

Fernandes, A.J. 1991. O Complexo Embu no leste do estado de São Paulo: contribuição ao conhecimento da litoestratigrafia e da evolução estrutural e metamórfica. Dissertação de mestrado, Instituto de Geociências, Universidade de São Paulo, São Paulo, 120 p.

Fernandes, A. L. 1997. Tectônica Cenozóica na porção média da Bacia do rio Piracicaba e sua aplicação à hidrogeologia. Tese de doutoramento, Instituto de Geociências, Universidade de São Paulo, São Paulo, 244 p.

Fernandes da Silva, P.C. 1998. Tectônica rúptil da região entre Pilar do Sul e Votorantim, SP. Revista Brasileira de Geologia, 28:485-494.

Freeze, R. A. \& Cherry, J. A. 1979. Groundwater / R. Allan Freeze, John A. Cherry. Second Edition. Englewood Cliffs, N.J., Prentice-Hall, 604 p.

Ferrari, A.L. 2001. Evolução Tectônica do Graben da Guanabara. Tese de doutoramento, Instituto de Geociências, Universidade de São Paulo, São Paulo, $412 p$. 
Golts, S. \& Rosenthal, E. 1993. A morphotectonic map of the northern Arava in Israel, derived from isobase lines. Geomorphology, 7:305-315.

Grohmann, C. H. 2004. Morphometric analysis in geographic information systems: applications of free software GRASS and R. Computers \& Geoscienies, 30:10551067.

Grohmann, C.H. \& Steiner, S.S. 2006. SRTM Resample with Short Distance-Low Nugget Kriging. In: International Symposium on Terrain Analysis and Digital Terrain Modelling, Nanjing, China, Proceedings, Nanjing, CD-ROM.

Hancock, P.L. 1985. Brittle microtectonics: principles and practice. Journal of Structural Geology, 7:437-457.

Hancock, P.L. \& Engelder, T. 1989. Neotectonic joints. Geological Society of American Bulletin, 101:1197-1208.

Hartwig, M.E. 2006. Tectônica rúptil mesozóica-cenozóica na região da Serra dos Órgãos, RJ. Dissertação de mestrado, Instituto de Geociências, Universidade de São Paulo, São Paulo, 117p.

Hasui, Y.; Penalva, F.; Hennies, W. T. 1969. Geologia do Grupo São Roque. In: SBG, Congresso Brasileiro de Geologia, 23, Salvador, Anais, Salvador, SBG, p.101-34.

Hasui, Y. \& Hama, M. 1972. Geocronologia do Grupo São Roque pelo método potássioargônio. Revista Brasileira de Geociências, 2:18-24.

Hasui, Y. 1973. Tectônica da área das Folhas de São Roque e Pilar do Sul, São Paulo. Tese de Livre Docência, Instituto de Geociências, Universidade de São Paulo, 190p.

Hasui, Y. 1975. Geologia da Folha de São Roque, São Paulo. Boletim IG - USP, 6: 95108.

Hasui, Y. \& Sadowski, G. R. 1976. Evolução geológica do Pré-cambriano na região sudeste do Estado de São Paulo. Revista Brasileira de Geociências, 6:157-183.

Hasui, Y.; Carneiro, C.D.R.; Bistrichi, C.A. 1981. O Embasamento pré-cambriano e eopaleozóico em São Paulo. In: Almeida, F.F.M. et al. Mapa geológico do estado de São Paulo, escala 1:500.000. São Paulo: IPT/PRÓ-MINÉRIO, p.12-45.

Hennies, W.T.; Hasui, Y.; Penalva, F. 1967. O falhamento transcorrente de Taxaquara. In: SBG, Congresso Brasileiro de Geologia, 21, Curitiba, Anais, Curitiba, SBG, p.159-168.

Hiruma, S.T. 1999. Neotectônica no planalto de Campos de Jordão, SP. Dissertação de Mestrado, Instituto de Geociências, Universidade de São Paulo, São Paulo, 102p.

Hiruma, S.T. \& Riccomini, C. 1999. Análise morfométrica em neotectônica: o exemplo do planalto de Campos do Jordão, SP. Revista do Instituto Geológico, 20:5-19.

Hobson, R.D. 1972. Surface roughness in topography: quantitative approach. In: Chorley, R.J. (ed.) Spatial analysis in geomorphology. New York, Harper and Row, p.225-245.

Hodgson, R.A. 1961. Regional study of joiting in Comb Ridge - Navajo Mountain area, Arizona and Utah. Geological Society of America Bulletin, 45:1-38.

Hoek, E. \& Bray, J.W. 1981. Rock Slope Engineering. London, The Institution of Mining and Metallurgy, $358 \mathrm{p}$. 
Horton, R.E. 1945. Erosional development of streams and their drainage basins: hydrophysical approach to quantitative morphology. Geological Society of America Bulletin, 56:275-370.

Hvorslev, M. J. 1951. Time lag and soil permeability. U.S. Army Corps of engineers, Waterways experiment station, Bulletin No. 36.

Ihaka, R. \& Gentleman, R. 1996. R: A languange for data analysis and graphics. Journal of Computional and Graphical Statistics, 5:299-314.

Janasi, V. A. \& Ulbrich, H. H. G. J. 1985. Avaliação das informações disponíveis para granitóides do Estado de São Paulo. In: SBG, Simpósio Regional de Geologia, 5, São Paulo, Atas, São Paulo, SBG, p.133-146.

Jenkins, D. N. \& Prentice, J. K. 1982. Theory for aquifer test analysis in fractured rocks under linear (nonradial) flow conditions. Ground Water, 20:12-21.

Jesus, I.P.S. 2005. Caracterização dos aqüíferos em meio cristalino da porção oeste da Bacia do Alto Tietê. Tese de doutoramento, Instituto de Geociências, Universidade de São Paulo, São Paulo, 203p.

Jianjun, H.; Mukang, H.; Ollier, C.D. 1997. A morphometric method to determine neotectonic activity of the Weihe Basin in northwestern China. Episodes, 20:95-99.

Köppen, W. 1948. Climatologia: con un estudio de los climas de la Tierra. México, Fondo Econômica, 479 p.

Kruseman, G.P. \& de Ridder, N.A. 1990. Slug Tests. In: Kruseman, G.P. \& de Ridder, N.A. (eds.) Analysis and evaluation of pumping test data. The Netherlands, ILRI, pp. $237-244$.

Liu, C.C. 1987. A geologia estrutural do Rio de Janeiro vista através de imagens MSS do Landsat. In: SBG/RJ-ES, Simpósio Regional de Geologia, 1, Rio de Janeiro, Anais, Rio de Janeiro, SBG/RJ-ES, p.164-188.

Loke, M. H. 1999. RES2DMOD, versino 2.2, Rapid 2D resistivity forward modelling using the finite difference and finite-element methods.. Austin, WennerSchlumberger, 22p.

Madrucci, V. 2004. Prospecção de água subterrânea em terreno cristalino utilizando-se análise integrada de dados de sensoriamento remoto, geofísicos e técnicas de geoprocessamento, região de Lindóia, SP. Tese de doutoramento, Instituto de Geociências, Universidade de São Paulo, São Paulo, 226 p.

Manuel Filho, J. 1996. Modelo de dimensão fractal para avaliação de parâmetros hidráulicos em meio fissural. Tese de doutoramento, Instituto de Geociências, Universidade de São Paulo, São Paulo, 197 p.

Meiser \& Earl hidrogeologists 1982. Use of fractures traces in water well location: $A$ handbook. Office of water research \& technology, 55p.

Mitasova, H. \& Mitas, L. 1993. Interpolation by regularized spline with tension: I. Theory and implementation. Mathematical Geology, 25:641-655.

Mitasova, H. \& Hofierka, J. 1993. Interpolation by regularized spline with tension: II. Application to terrain modeling and surface geometry analysis. Mathematical Geology, 25:657-669. 
Neves, M.A.; Morales, N.; Borges, M.S.; Ebert, H.D. 2003. Compartimentação Morfotectônica da região de Jundiaí (SP). Revista Brasileira de Geociências, 33:167-176.

Neves, M. A. 2005. Análise integrada aplicada à exploração de água subterrânea na Bacia do Rio Jundiaí (SP). Tese de doutoramento, Instituto de Geociências e Ciências Exatas, Universidade Estadual Paulista, Rio Claro, 200 p.

Neves, M. \& Morales, N. 2006. Structural control over well productivity in the Jundiaí River Catchment, Southeastern Brazil. Anais da Academia Brasileira de Ciências, 79:307-320.

Neves, M. \& Morales, N. 2007. Well productivity controlling factors in crystalline terrains of southeastern Brazil. Hydrogeology Journal, 15:471-482.

Novakowski, K. S. 1995. Groundwater flow in fractured rocks. Waterloo: Centre for Groundwater Research, Course notes, 46 p.

Petit, J.P. 1987. Criteria for the sense of movement on fault surfaces in brittle rocks. Journal of Strutural Geology, 9:597-608.

Riccomini, C. 1989. O Rift Continental do Sudeste do Brasil. Tese de Doutoramento, Instituto de Geociências, Universidade de São Paulo, São Paulo, 256 p.

Riccomini, C. 1995. Padrão de fraturamento do Maciço Alcalino de Cananéia, Estado de São Paulo: relações com a tectônica mesozóica-cenozóica do sudeste do Brasil. Revista Brasileira de Geociências, 25:79-84.

Riccomini, C. \& Crósta, A.P. 1988. Análise preliminar de lineamentos em imagens de sensores remotos aplicada à prospecção mineral na área dos granitóides Mandira, SP. Boletim Instituto de Geociências USP, Série Científica, 19:23-37.

Riccomini, C.; Sant'Anna, L. G.; Ferrari, A. L. 2004. Evolução geológica do Rift Continental do Sudeste do Brasil. In: Mantesso-Neto, V.; Bartorelli, A.; Carneiro, C.D.R.; Brito Neves, B.B. (eds.) Geologia do Continente Sul-Americano: evolução da obra de Fernando Flávio Marques de Almeida. São Paulo, Beca, p.383-405.

Rodriguez, S.K. 1993. Neotectônica e sedimentação quaternária na região da "Volta Grande" do Rio Xingu, Altamira, Pará. Dissertação de Mestrado, Instituto de Geociências, Universidade de São Paulo, São Paulo, 106p.

Salvador, E.D. 1994. Análise Neotectônica da Região do Vale do Paraíba compreendida entre Cruzeiro $(S P)$ e Itatiaia $(R J)$. Dissertação de Mestrado, Instituto de Geociências, Universidade de São Paulo, São Paulo, 129p.

Salvador, E.D. \& Riccomini, C. 1995. Neotectônica da Região do Alto Estrutural de Queluz (SP-RJ, Brasil). Revista Brasileira de Geociências, 25:151-164.

Schobbenhaus, C.; Campos, D.A.; Derze, G.R.; Asmus, H.E. 1984. Geologia do Brasil. Texto explicativo do mapa geológico do Brasil e da área oceânica adjacente incluindo depósitos minerais, escala 1:2.500.000. Brasília, DNPM, 1984, 501 p.

Singhal, B.B.S. \& Gupta, R.P. 1984. Applied Hydrogeology of Fractured Rocks. Netherlands, Smith \& Schwartz, 400 p.

Smith, L. \& Schwartz, F.W. 1984. An analysis of the influence of fracture geometry on mass transport in fractured media. Water Resourses, 20:1241-1252. 
Snow, D. T. 1969. Anisotropic permeability of fractured media. Water Resources Research, 6:1273-1289.

Telford, W. M., Geldart, L. P., Sheriff, R. E. 1990. Applied geophysics. Second Edition. Cambridge, Cambridge University Press, 770 p.

Vignol-Lelarge, M.L.M.; Soliani Jr., E.; Poupeau, G. 1994. Datação pelos traços de fissão do domínio meridional da Serra do Mar (Arco de Ponta Grossa - Brasil). In: SBG, Congresso Brasileiro de Geologia, 38, Camboriú, Boletim de Resumos Expandidos, Camboriú, SBG, V.2, 379-380.

Vita-Finzi, C. 1986. Recent Earth movements - an introduction to neotectonics. London, Academic Press, 226p. 


\section{Anexo I - Figuras}

Figura 1 - Mapa de Localização

Figura 2 - Mapa Geológico

Figura 3 - Mapa Hipsométrico

Figura 4 - Lineamentos de sombreamento de relevo

Figura 5 - Lineamentos de aerofotometria

Figura 6 - Mapa de orientação de Vertentes

Figura 7 - Mapa de declividades

Figura 8 - Mapa de superfícies de base

Figura 9 - Mapa de superfícies de base, lineamentos e estruturas de campo

Figura 10 - Mapa geológico, linhas de isobase e lineamentos

Figura 11 - Mapa de densidade de lineamentos

Figura 12 - Mapa de densidade de drenagens

Figura 13 - Mapa de rugosidade de relevo

Figura 14 - Mapa de campo

Figura 15 - Perfis de eletrorresistividade na área de detalhe $A$

Figura 16 - Mapa de estruturas de poços na área de detalhe $A$

Figura 17 - Mapa de estruturas de poços na área de detalhe B

Figura 18 - Mapa de estruturas nos filtros dos poços na área de detalhe $A$

Figura 19 - Mapa de estruturas nos filtros dos poços na área de detalhe $B$

Figura 20 - Ensaio de bombeamento na área de detalhe $A$

Figura 21 - Mapa de variações das cargas hidráulicas na área de detalhe $A$

Figura 22 - Mapa de variações das cargas hidráulicas na área de detalhe $B$

Figura 23 - Mapa de densidades de lineamentos NW-SE

Figura 24 - Mapa de densidades de lineamentos NE-SEW

Figura 25 - Mapa de densidades de lineamentos E-W

Figura 26 - Mapa de densidades de lineamentos N-S 


\section{Figura 1 - Mapa de localização da área de estudos}
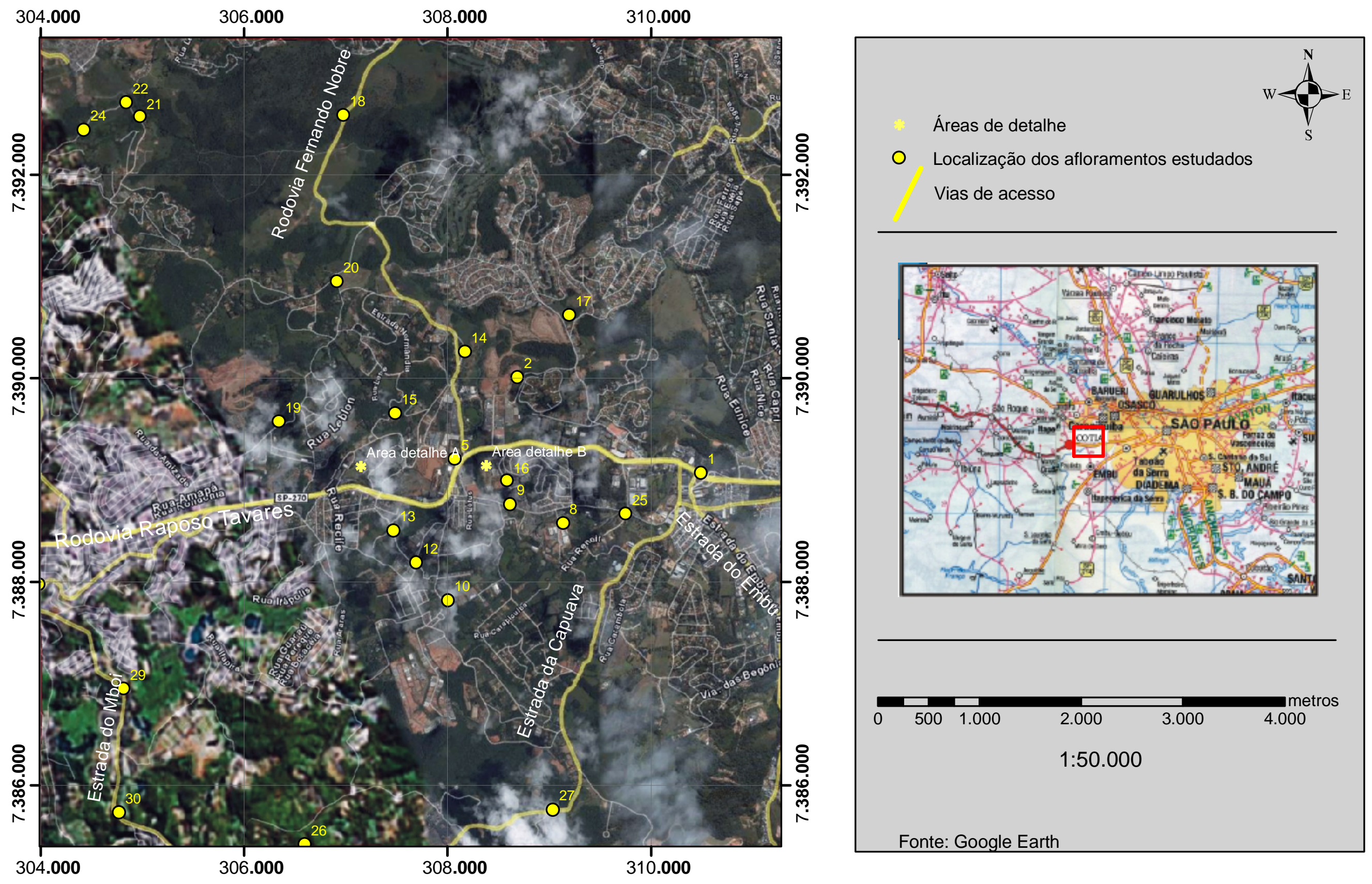

Fonte: Google Earth 


\section{Figura 2 - Mapa geológico da área}

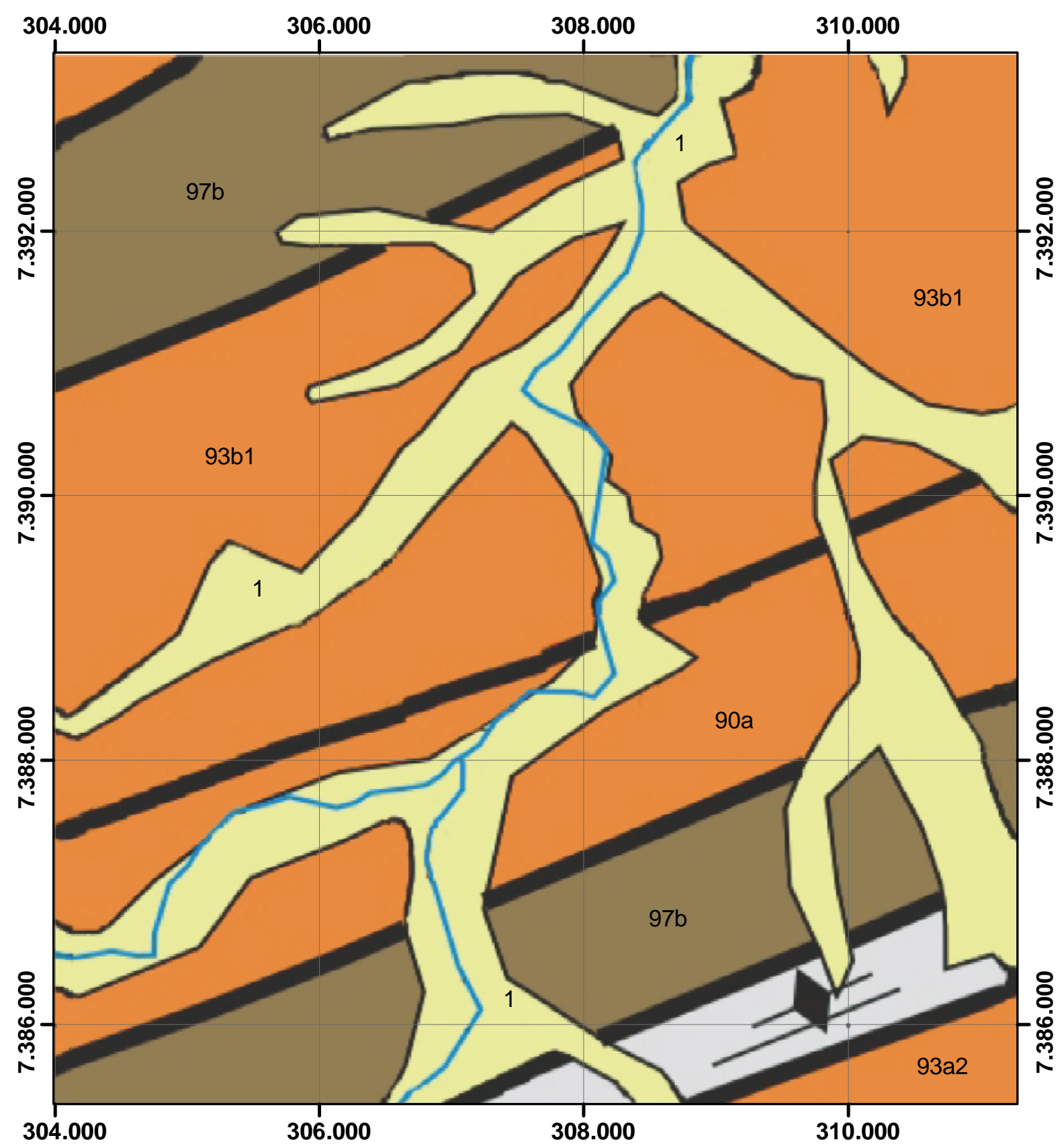

\section{CENOZÓICO}

Aluviões recentes atuais

\section{PROTEROZÓICO DOMÍNIO EMBÚ}

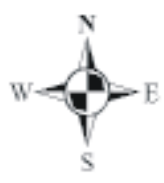

\section{Rochas ígneas}

Biotita granitos a granodioritos cinza-médios a rosados, porfiríticos a ineqüigranulares, foliados (Suíte Granitóide Piedade=89). Hornblenda-biotita granitóide, granodiorítico a monzogranítico, porfirítico, foliado (Ibiúna=90a); Tipo Ibiúna (90b); Biotita e/ou hornblenda gnaisses porfiroclásticos, localmente mig matizados (90c).

Melagranito (3b) cinza-esverdeado, porfirítico, com granada muscovita e turmalina, gnaissificado nas bordas (Colônia=92). Biotita monzogranitos, ineqüigranulares, Colonia=92). Biotita monzogranitos, ineqúigranulares, foliados (Tipo Itapevi=93a) e porfiríticos (Tipo Tapiraí $=93 \mathbf{b}$ ). Biotita granito a quartzomonzogranito, porfirítico, foliado (Itapevi=94). Granitóides porfiríticos e ineqüigranulares (São Sebastião=95a); (Laranjeira=95b); (Fazenda Dulviro=95c).

\section{Complexo Embu}

97b Rochas metapelíticas: Biotita-quartzo-muscovita xistos e granada-biotita xistos (com ou sem sillimanita) (a); Biotitaquartzo-muscovita xistos e granada-biotita xistos com diferentes estágios de migmatização, localmente feldspatizados e injetados por peg matitos (b)

Falha ou Zona de Cisalhamento de Caucaia

* Foliação tectônica principal vertical

Fonte: CPRM 1999, Carta geológica folha São Paulo, escala 1:250.000

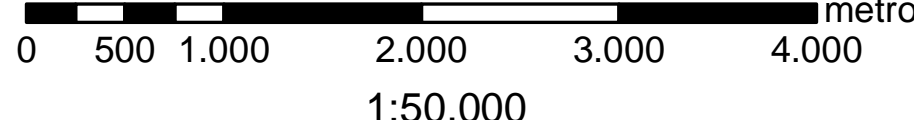


Figura 3 - Mapa hipsométrico

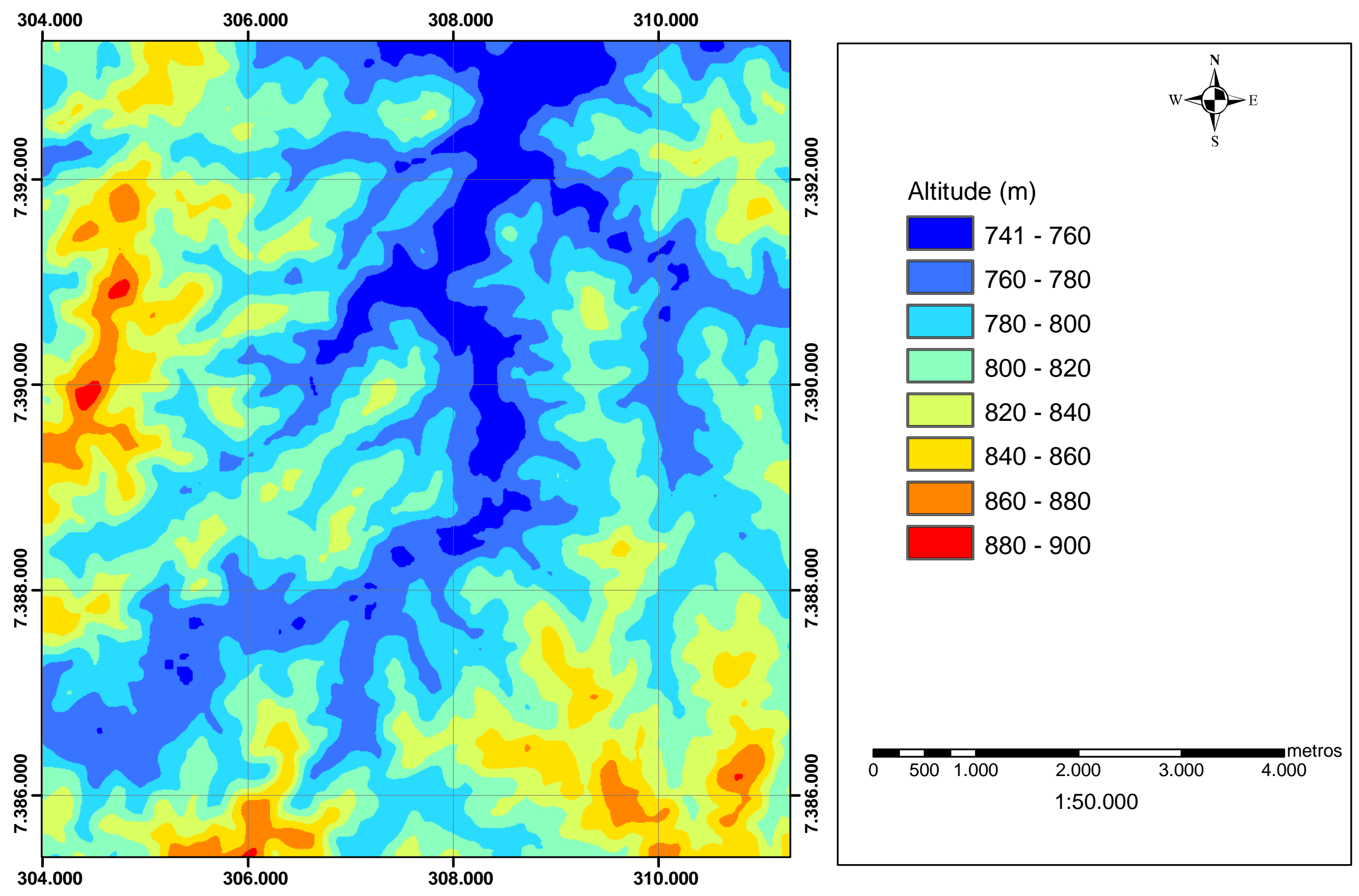


Figura 4 - Lineamentos de sombreamento de relevo composto
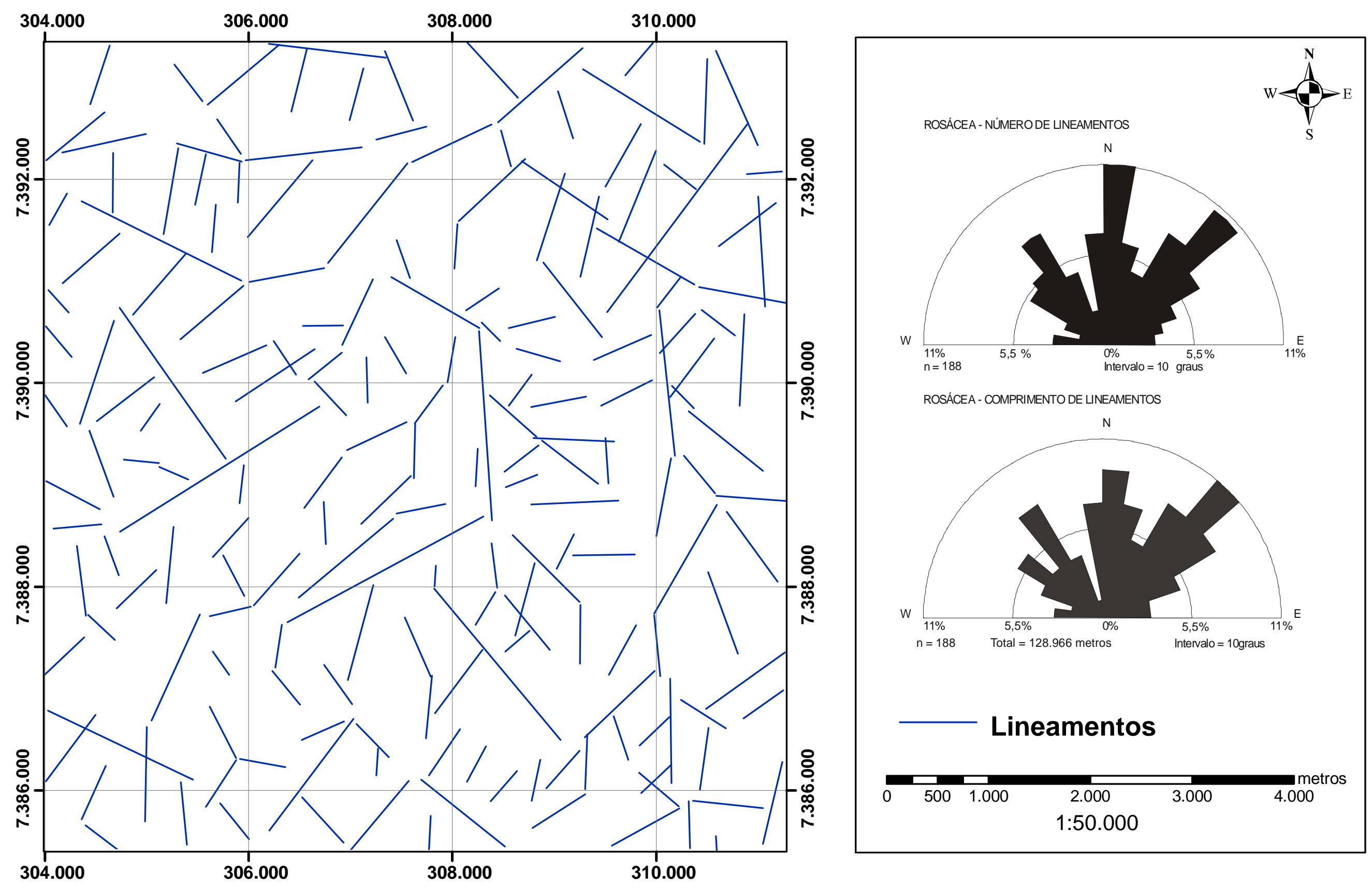


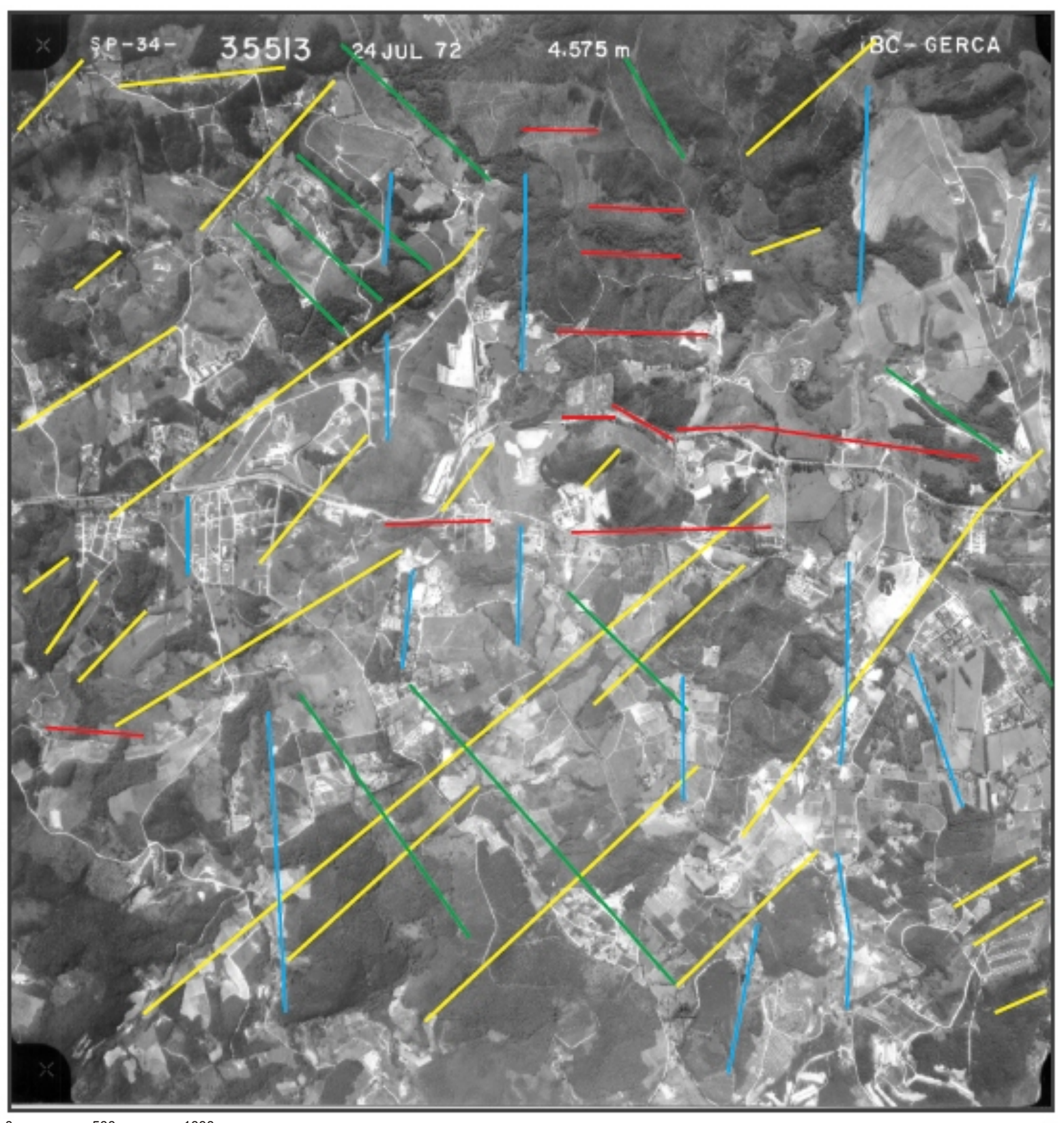

Figura 5

Lineamentos fotogeológicos

\section{Legenda}

I Lineametos N-S

- Lineamentos E-W

Lineamentos NE-SW

Lineamentos NW-SE

$\stackrel{500}{1}$ $1000 \mathrm{~m}$ 
Figura 6 - Mapa de orientação de vertentes

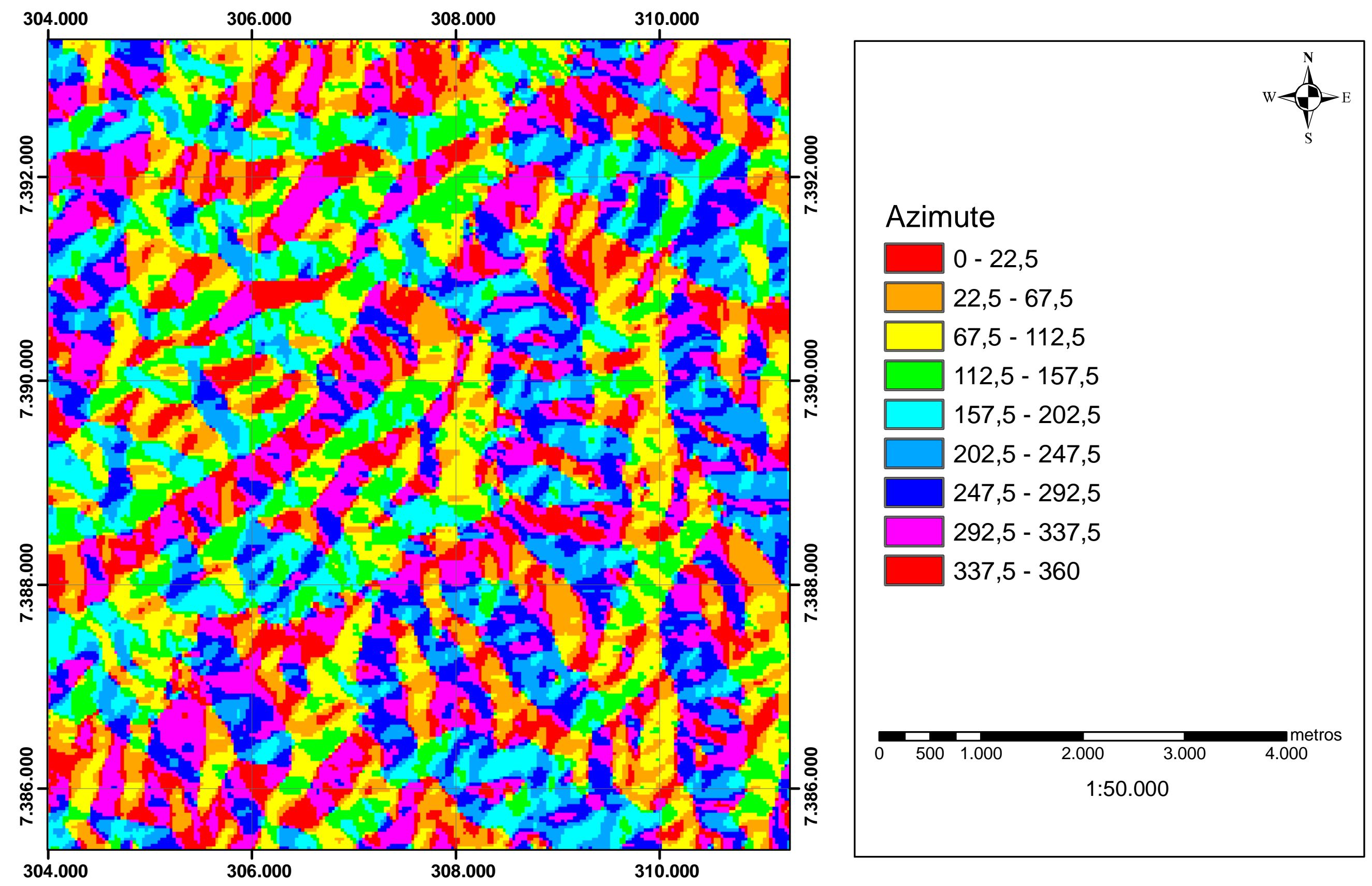


Figura 7 - Mapa de declividade do terreno
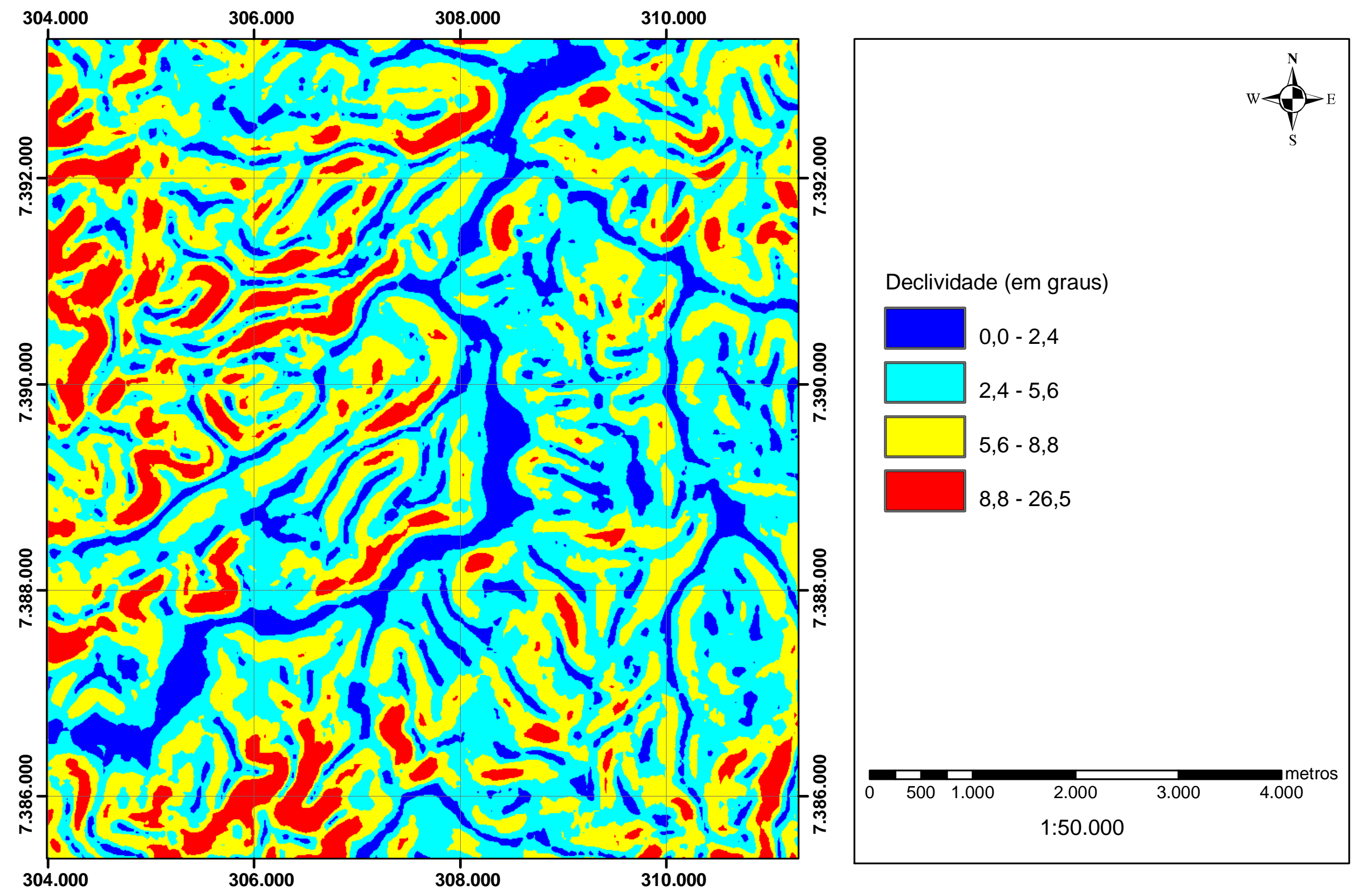
Figura 8 - Mapa de superfícies de base

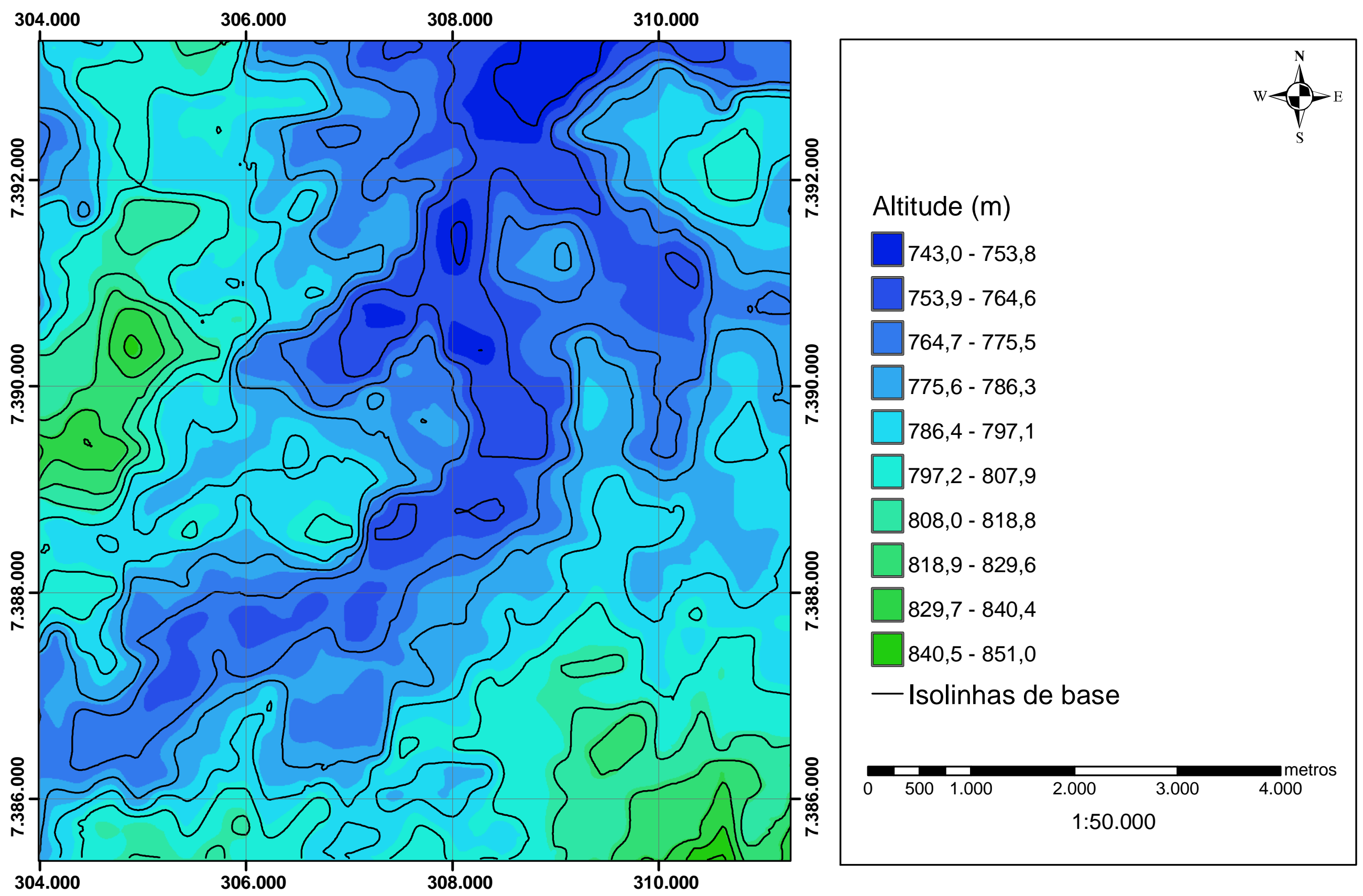


Figura 9 - Mapa de superfícies de base, lineamentos e estruturas de campo
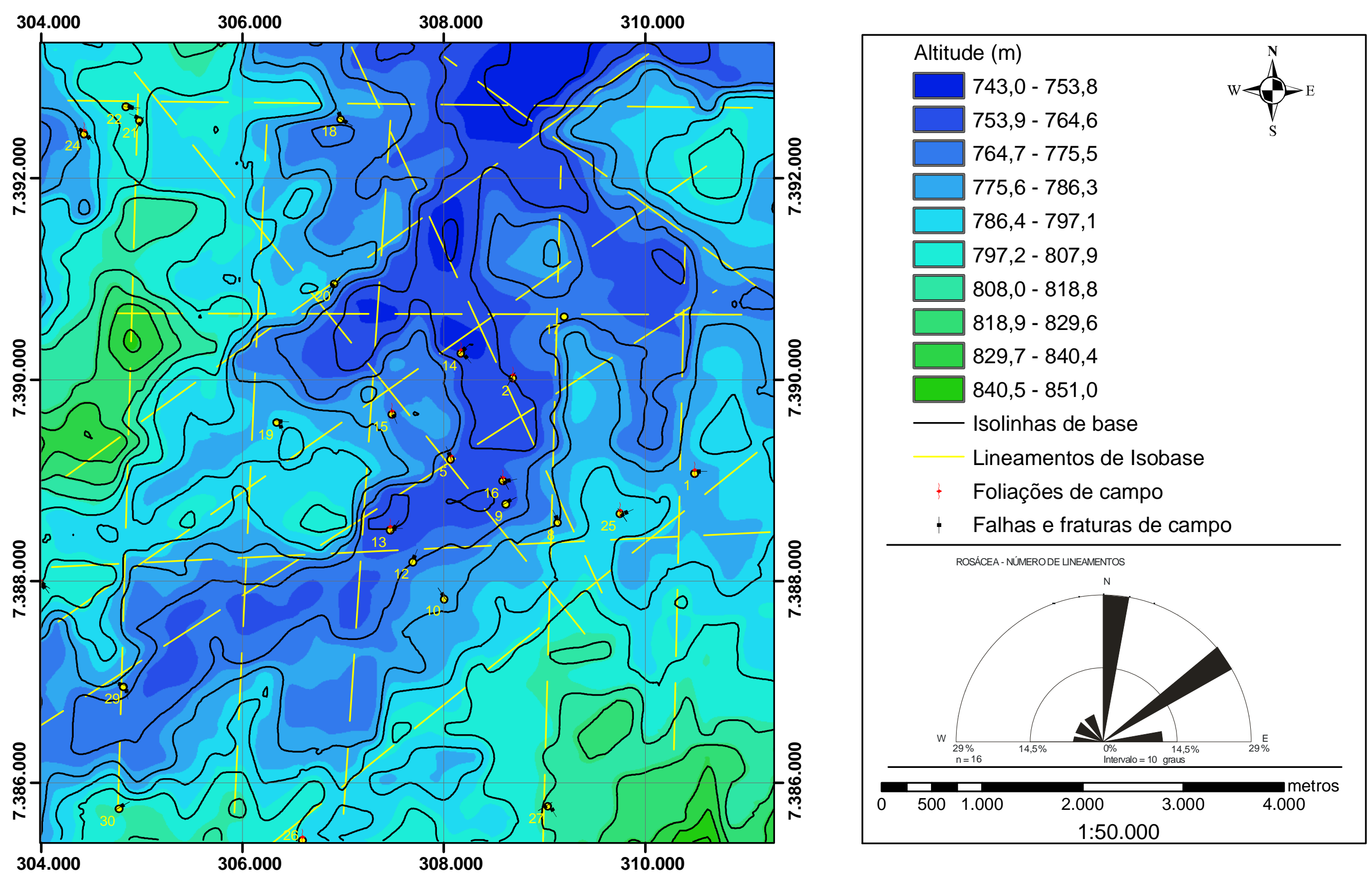
Figura 10 - Mapa geológico, linhas de isobase e lineamentos
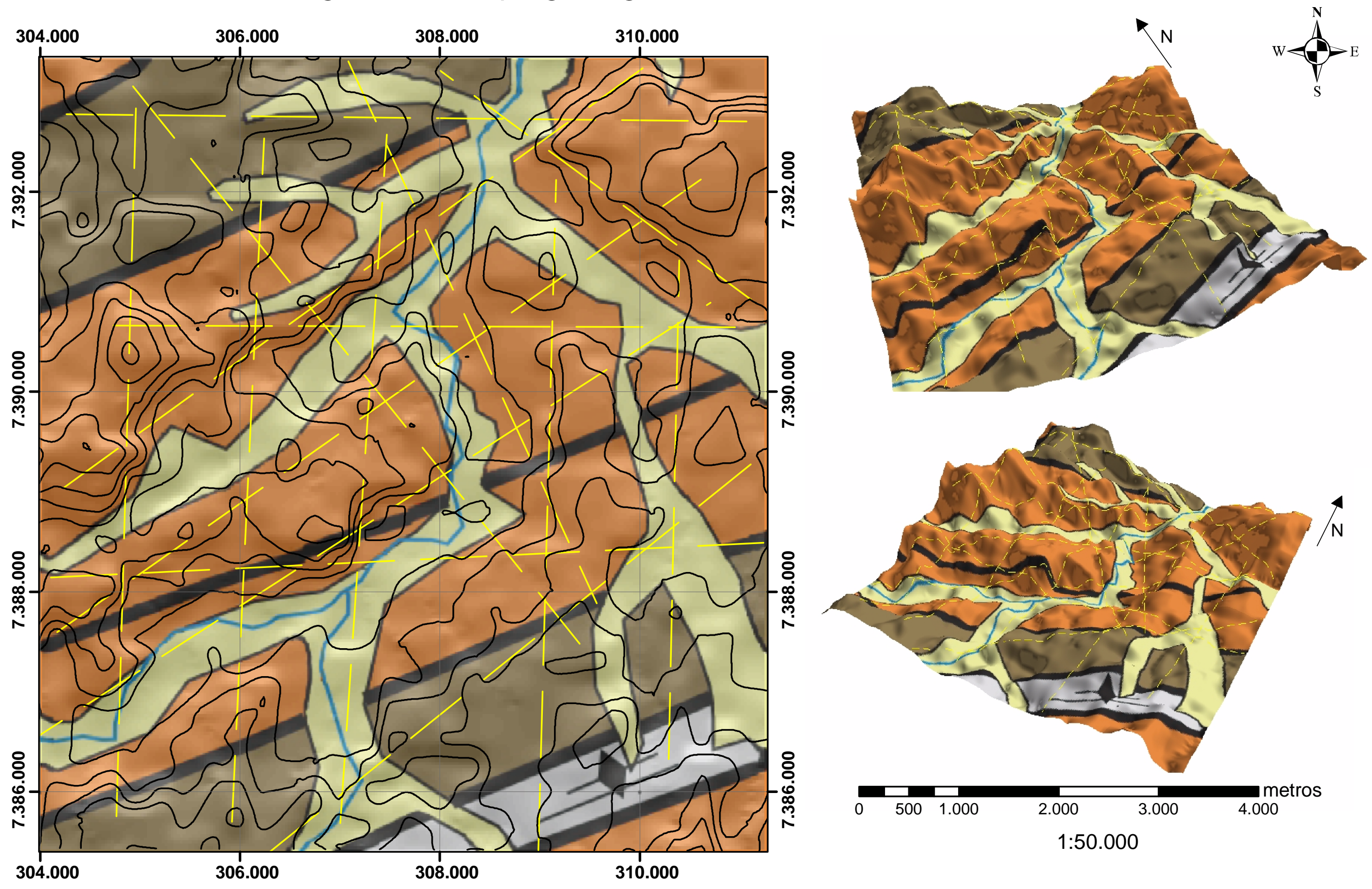
Figura 11 - Densidade de lineamentos
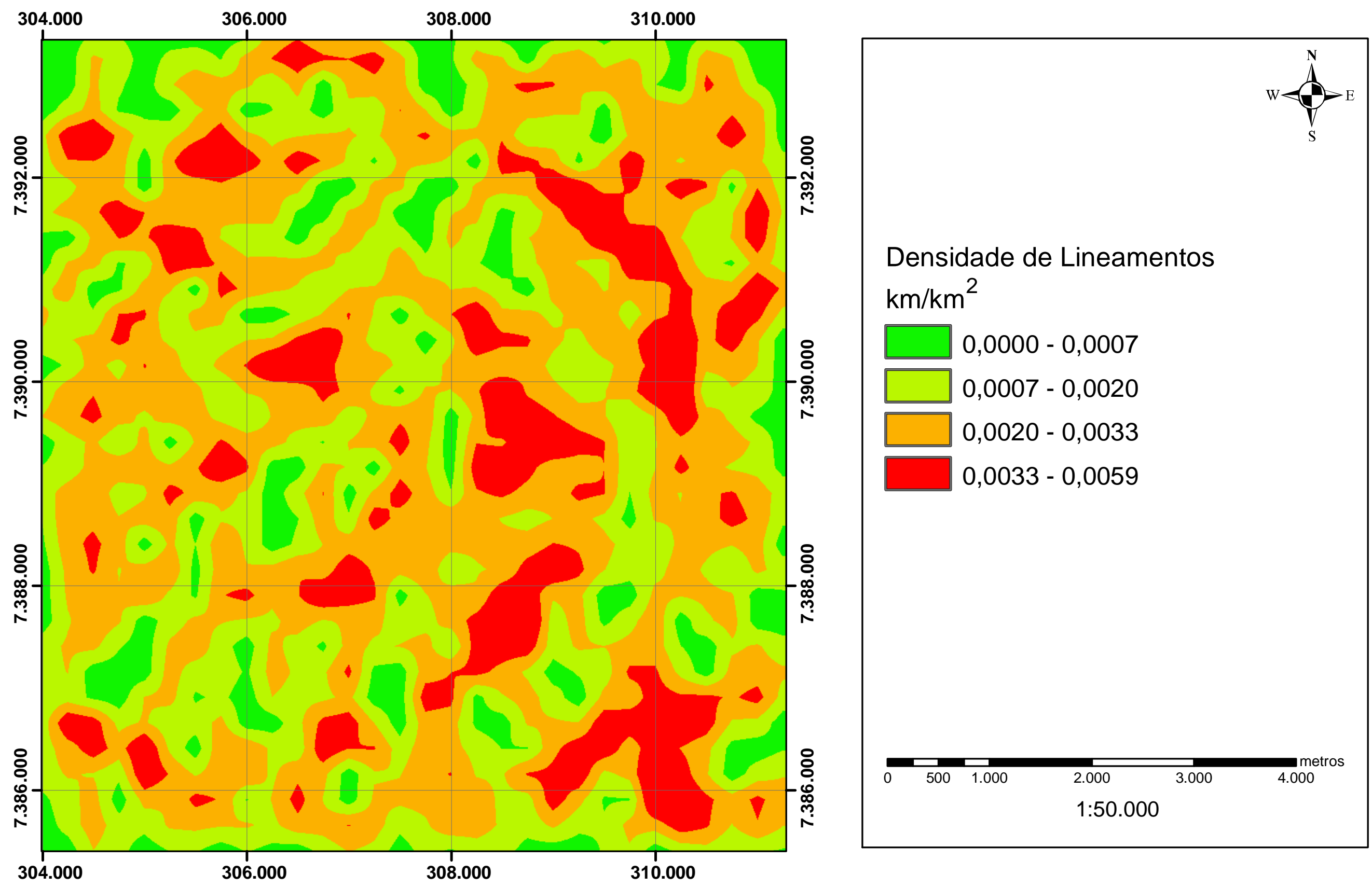
Figura 12 - Dendidade de drenagens

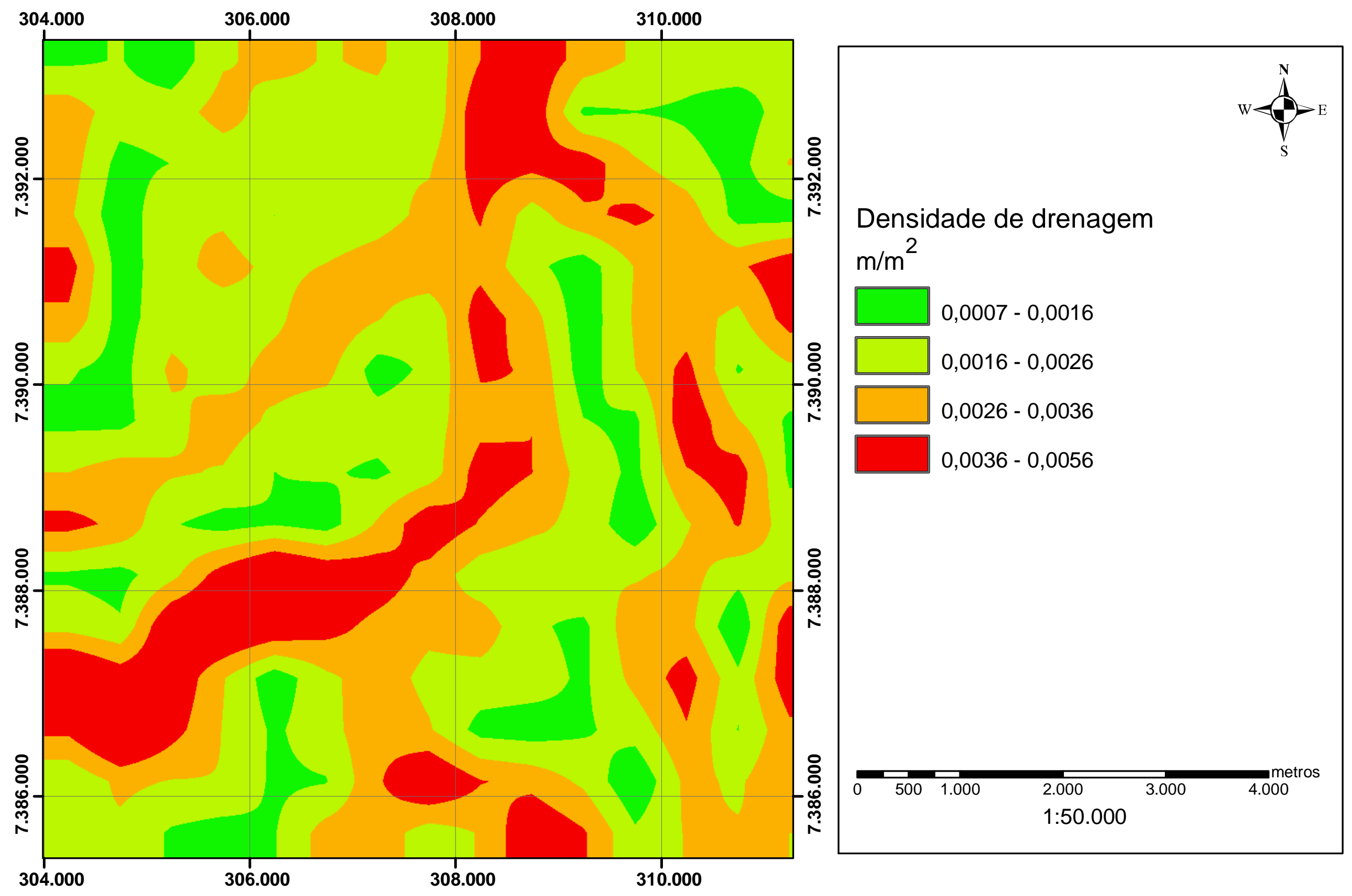


Figura 13 - Rugosidade de relevo

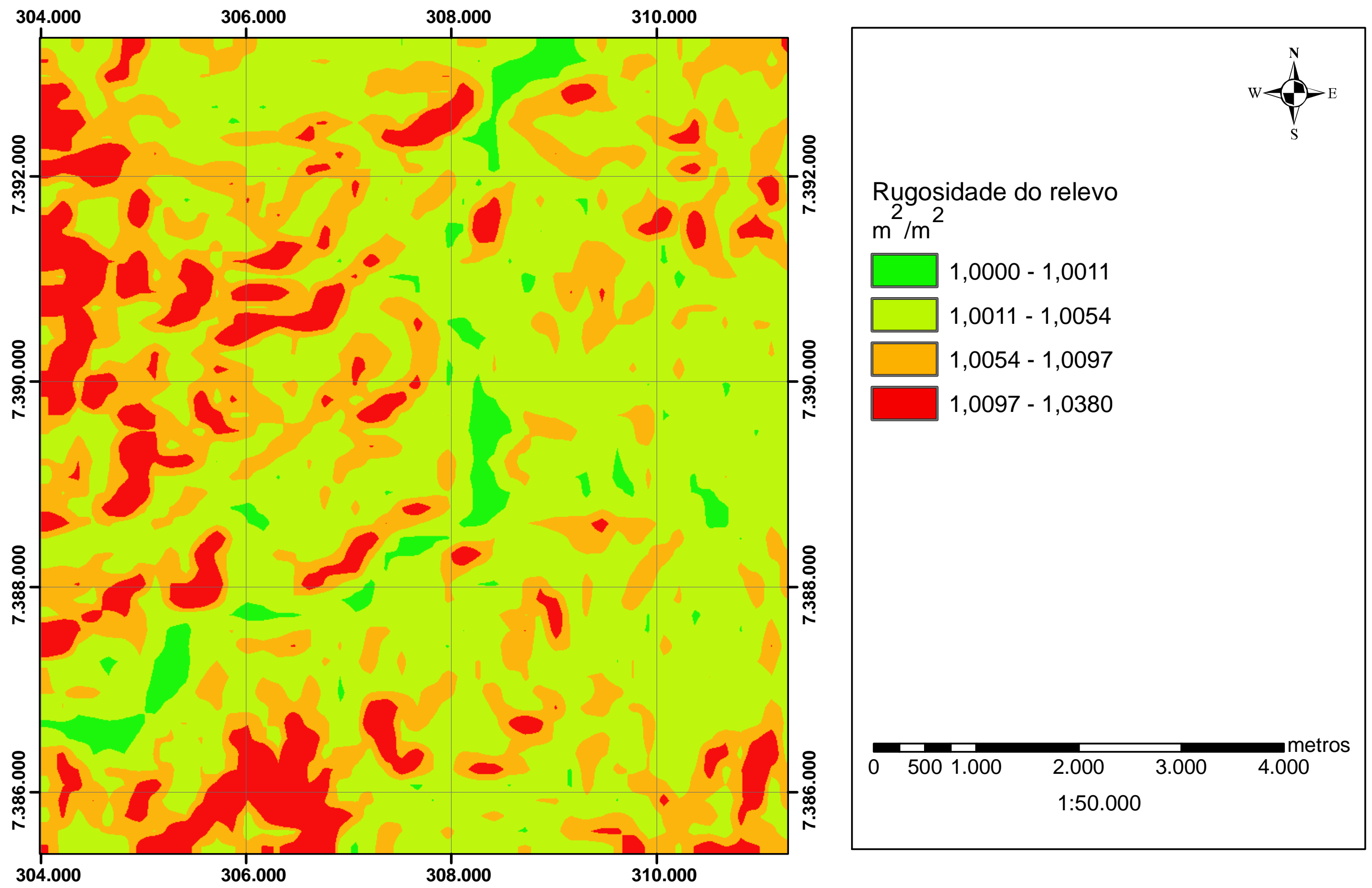


Figura 14 - Mapa de localização dos afloramentos e lineamentos interpretados

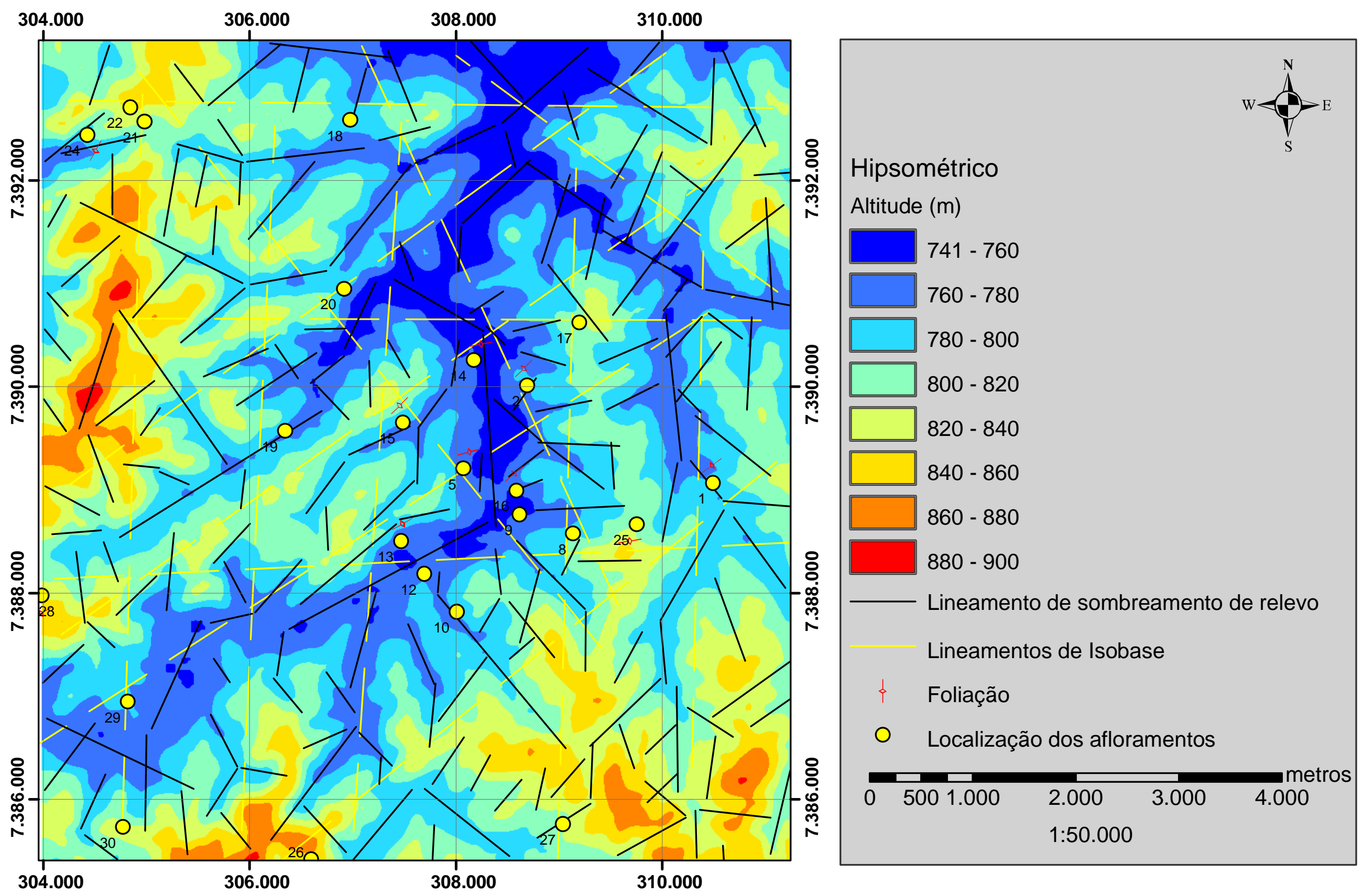


Figura 15 - Perfis de eletrorresistividade - área de detalhe A

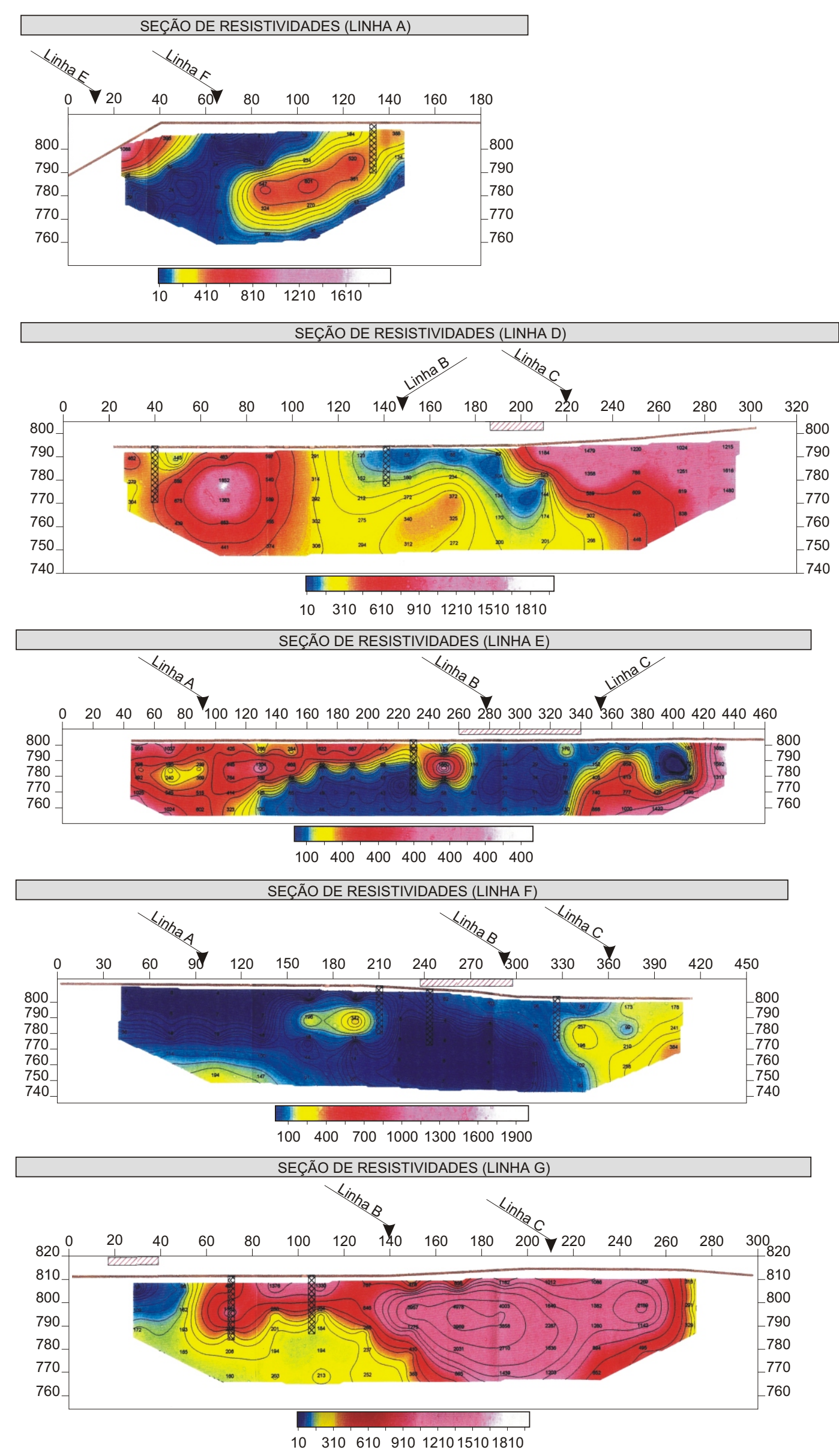

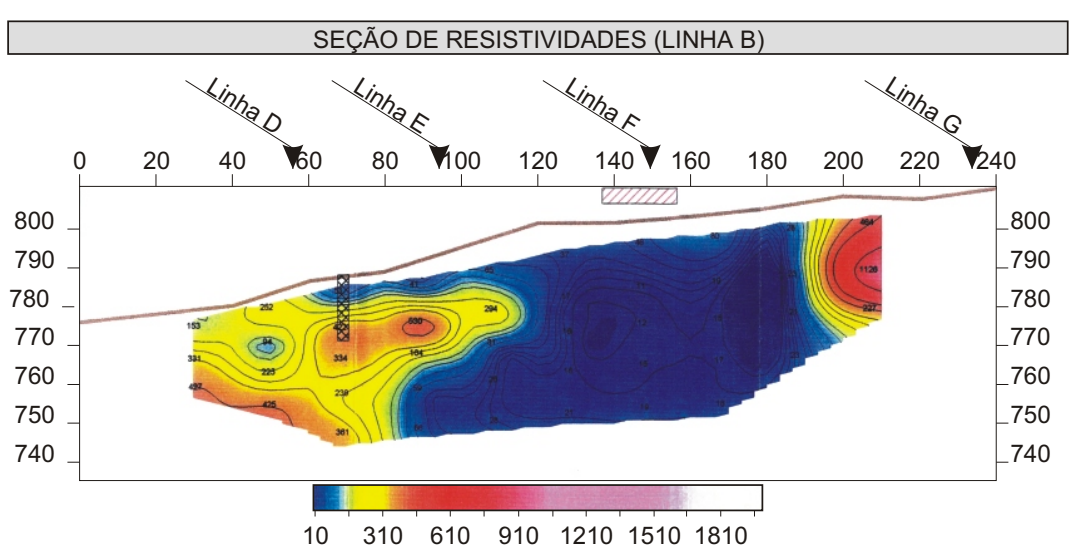

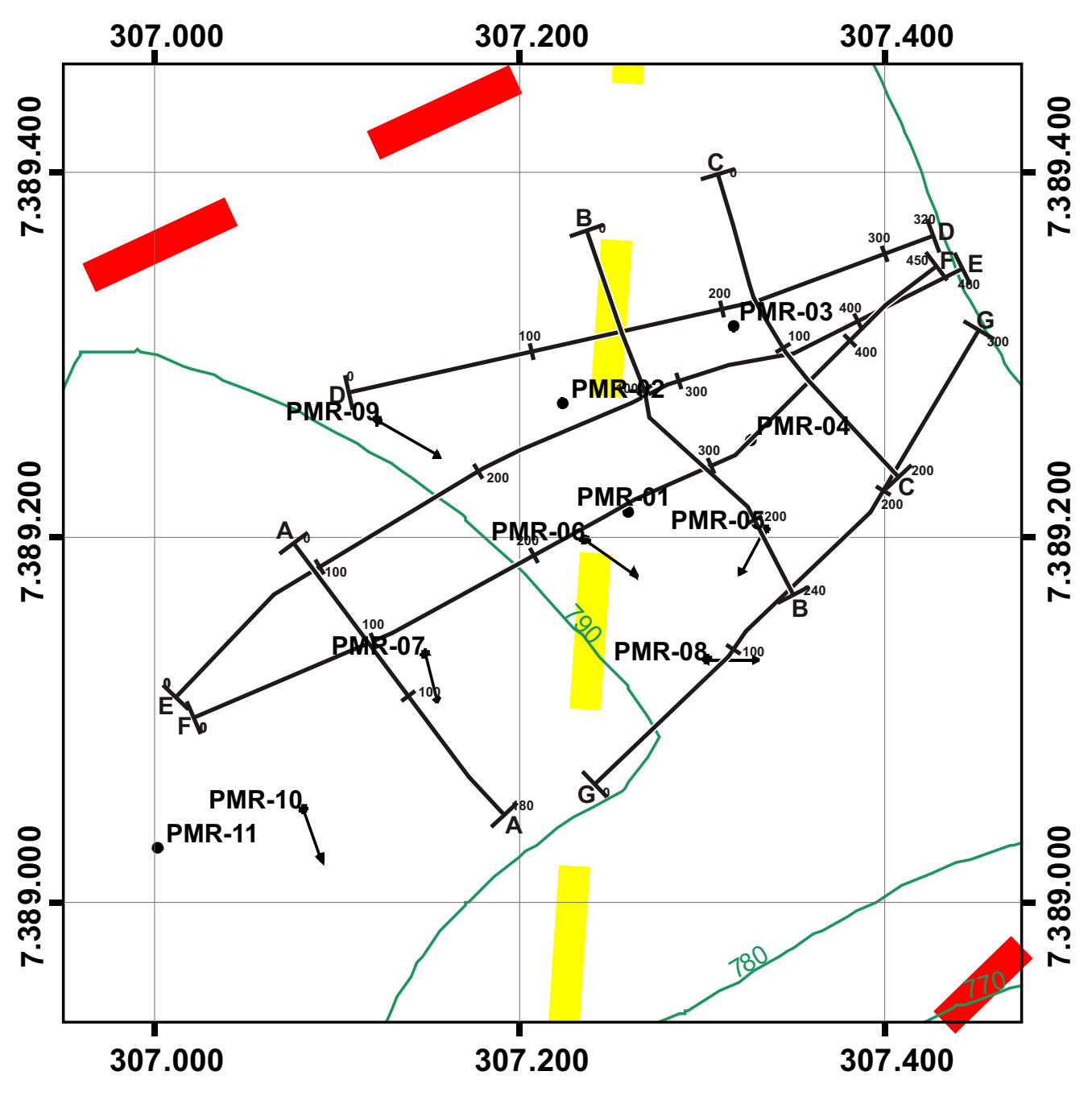

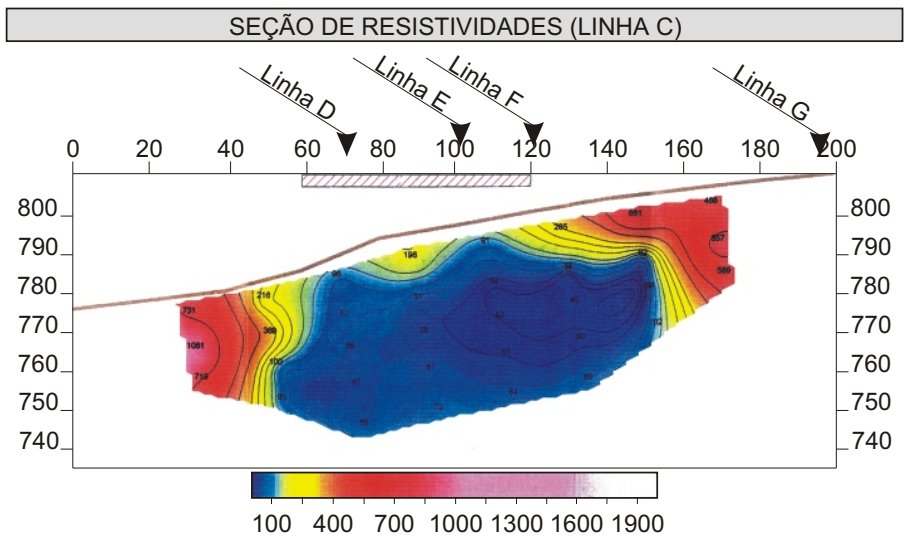

Lineamentos de isobase

- - - Lineamentos de sombreamento de relevo _ Isolinhas de base

AҢ ${ }^{A}$ Seções de eletrorresistividade

\section{Perfil de eletrorresistividade}

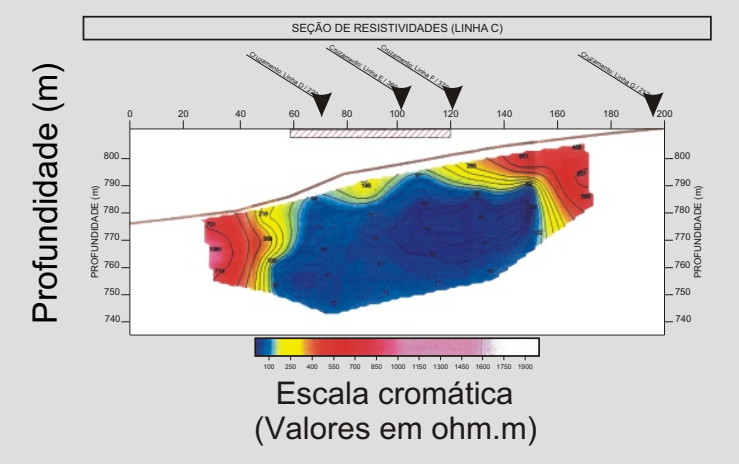

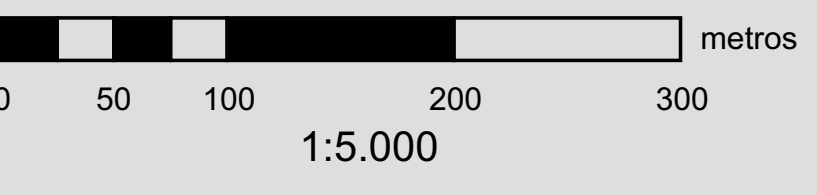


Figura 16 - Área de detalhe A - estruturas abertas nos poços
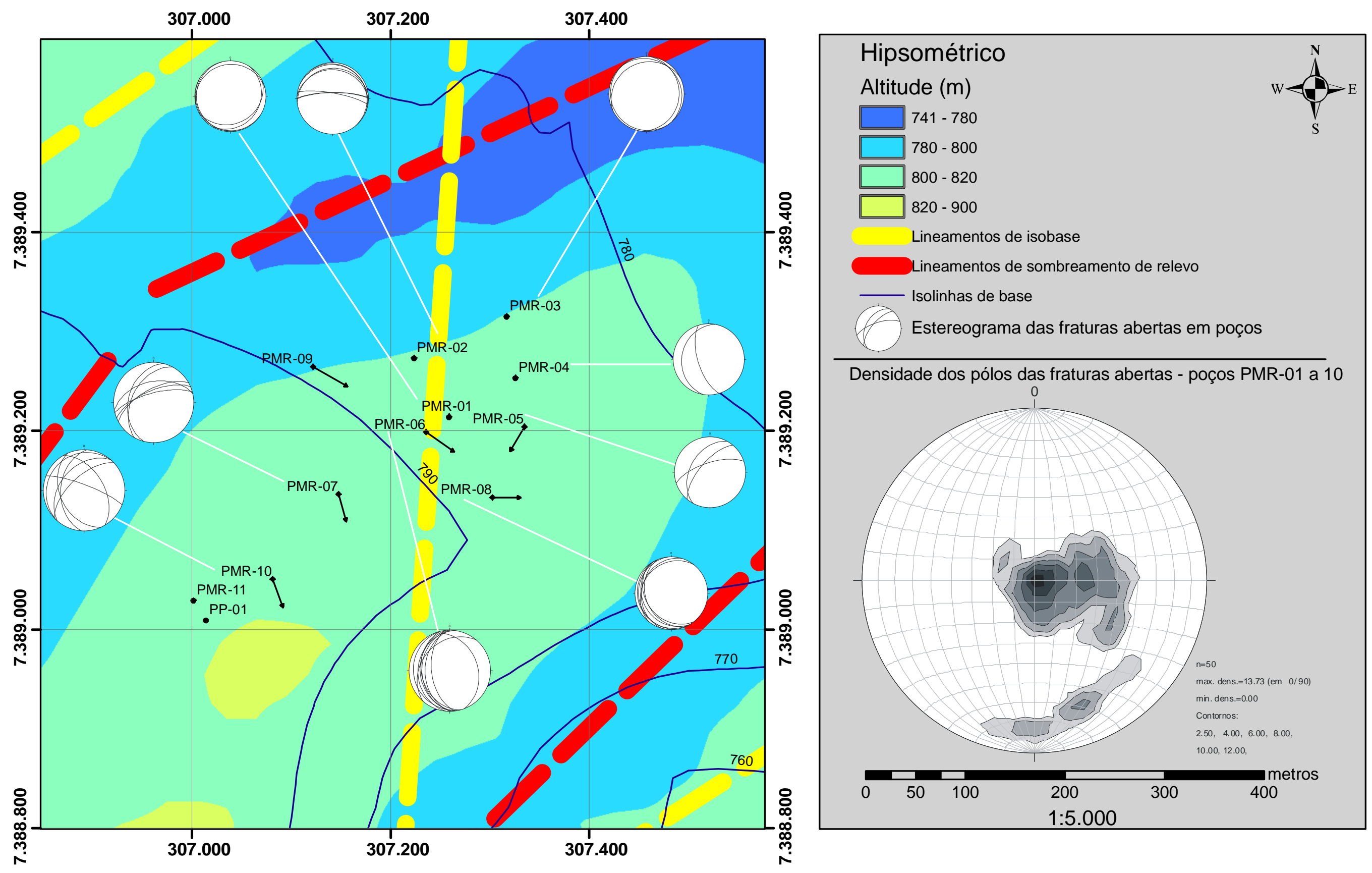
Figura 17 - Área de detalhe B - estruturas abertas nos poços

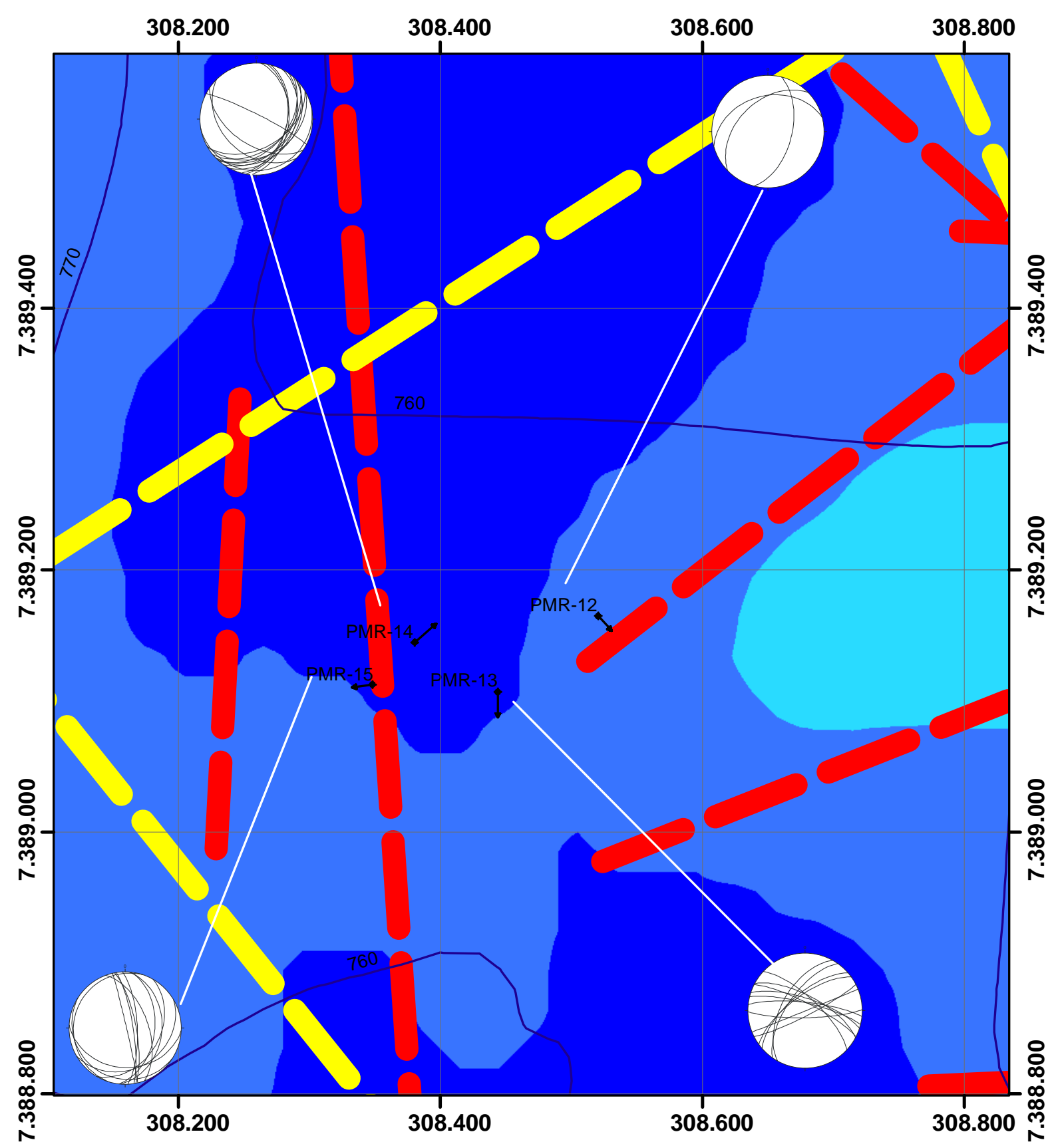

Hipsométrico

Value

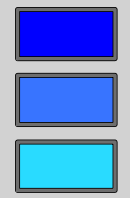

$741-760,5$

$760,5000001-780$

$780,0000001-897$

Lineamentos de isobase

Lineamentos de sombreamento de relevo

Isolinhas de base

Estereograma das fraturas abertas em poços

Densidade dos pólos das fraturas abertas - poços PMR-12 a 15

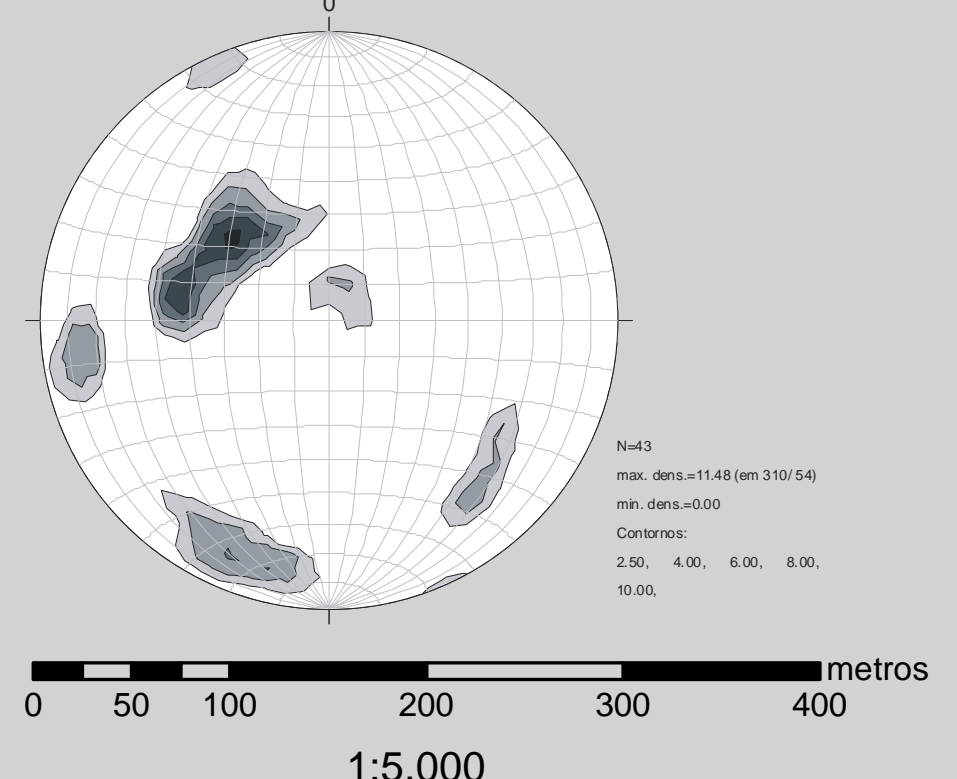


Figura 18 - Estruturas nos filtros dos poços - área de detalhe A

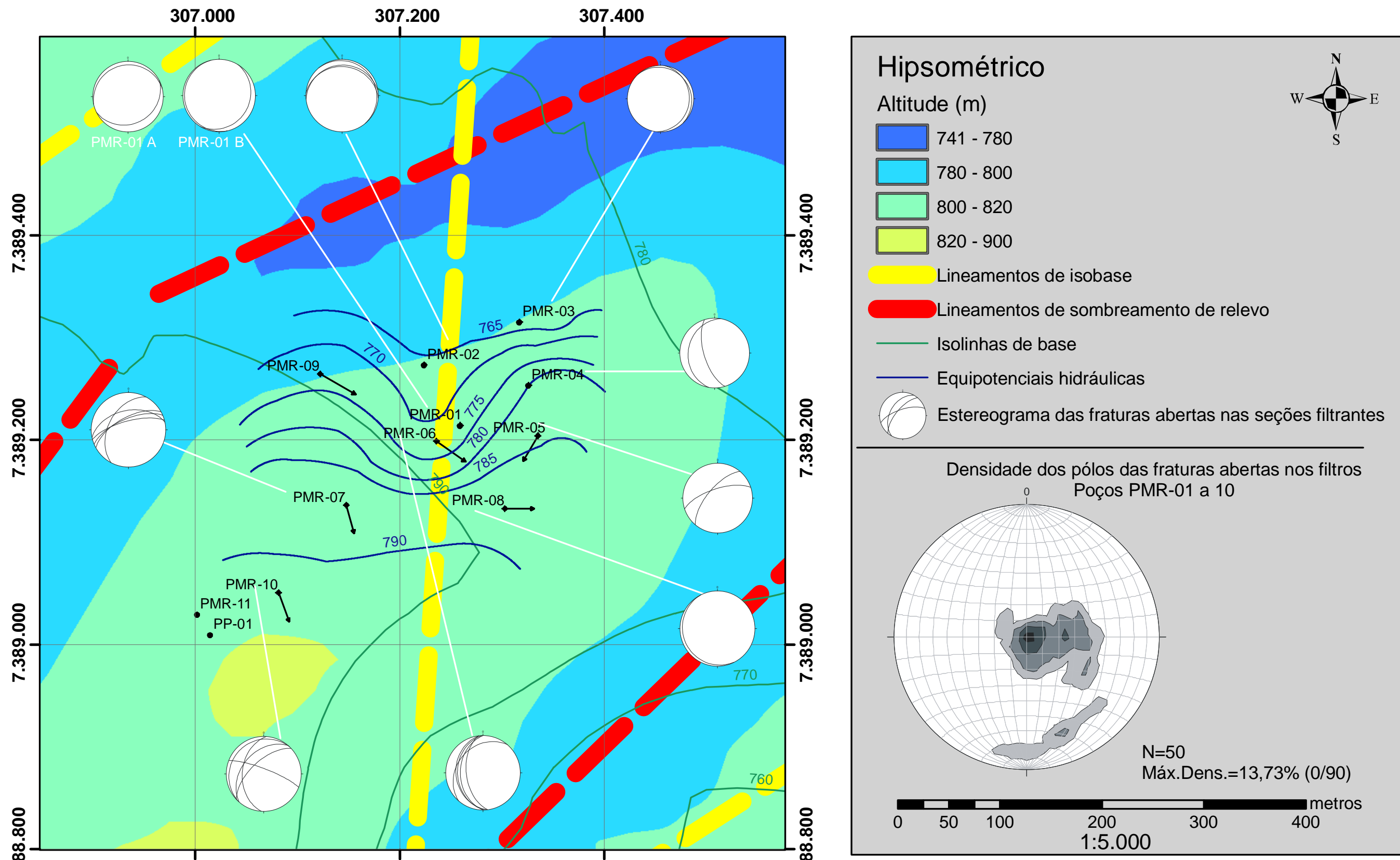


Figura 19 - Estruturas nos filtros dos poços - área de detalhe B
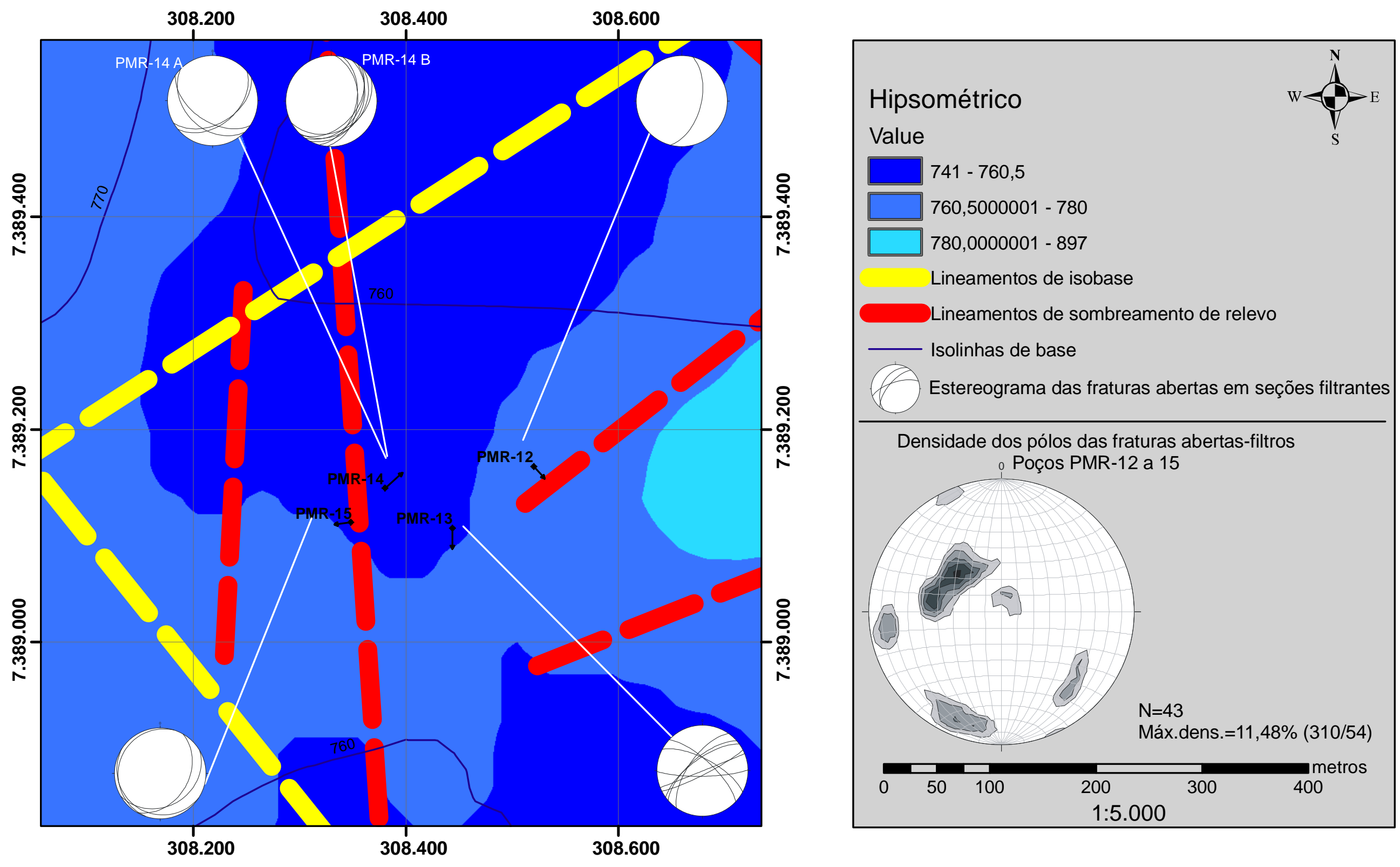
Figura 20 - Ensaio de bombeamento - área de detalhe A
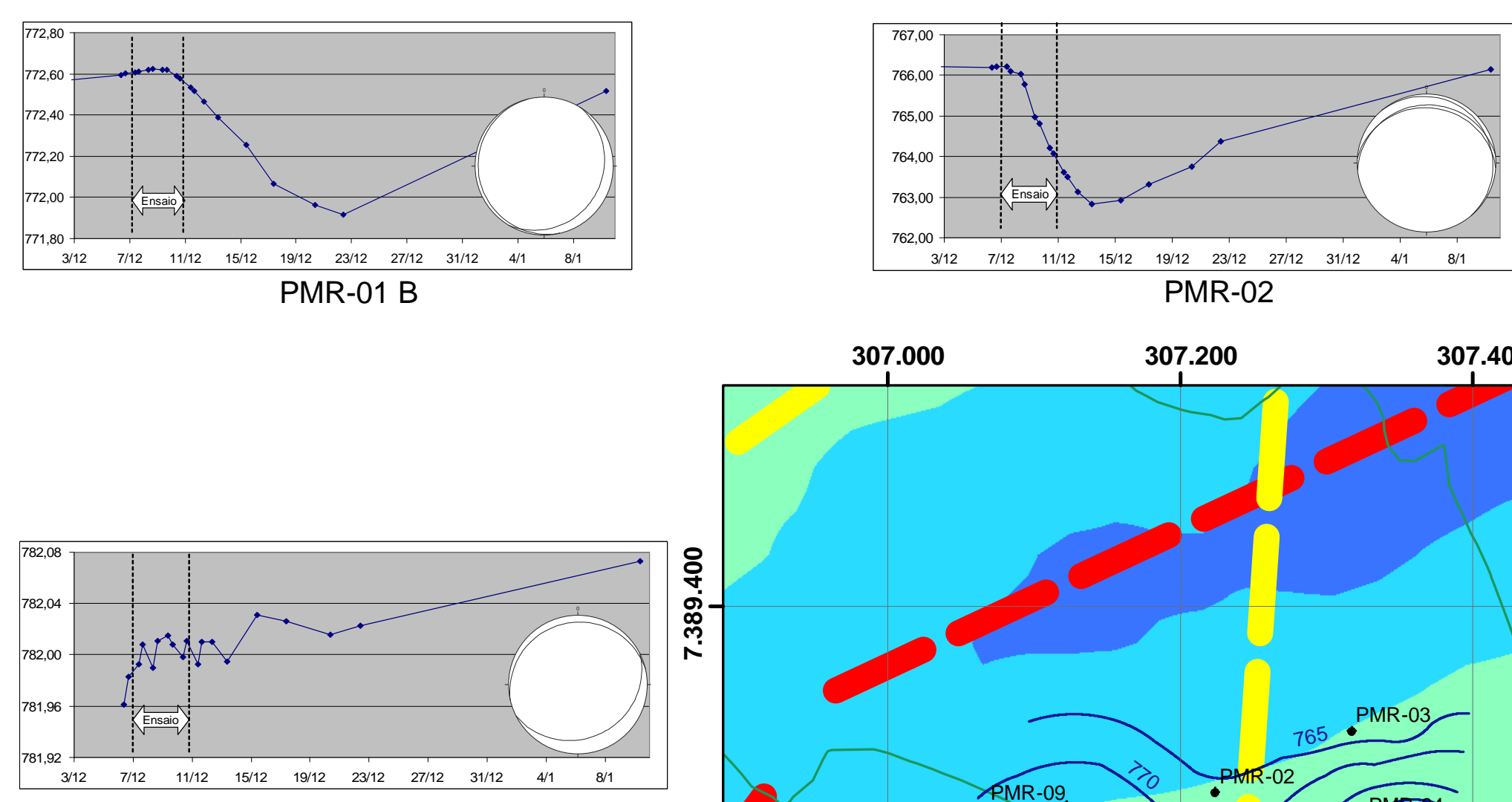
PMR-01 A

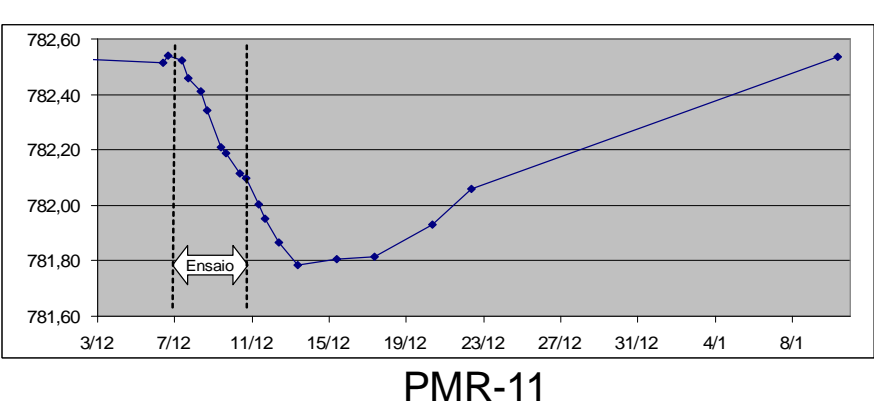

PMR-11

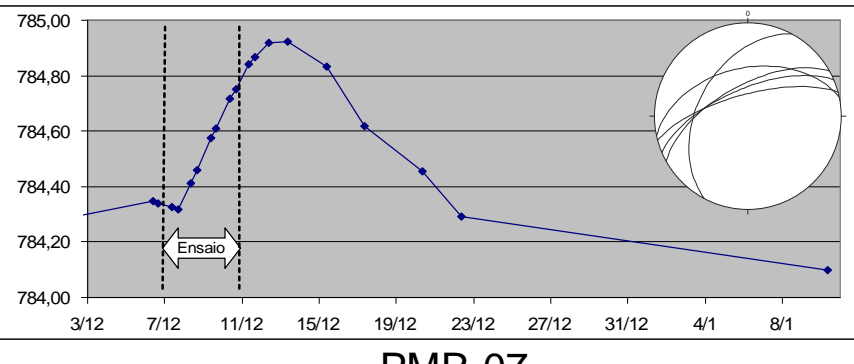

PMR-07

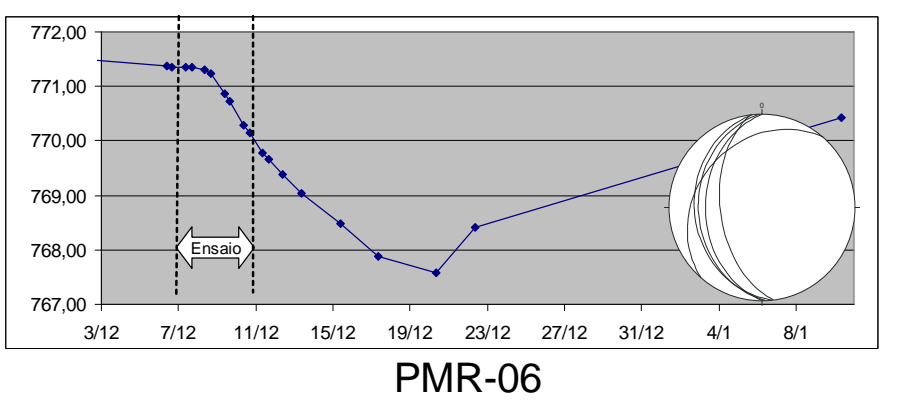

$\begin{array}{lll}307.000 & 307.200 & 307.400\end{array}$
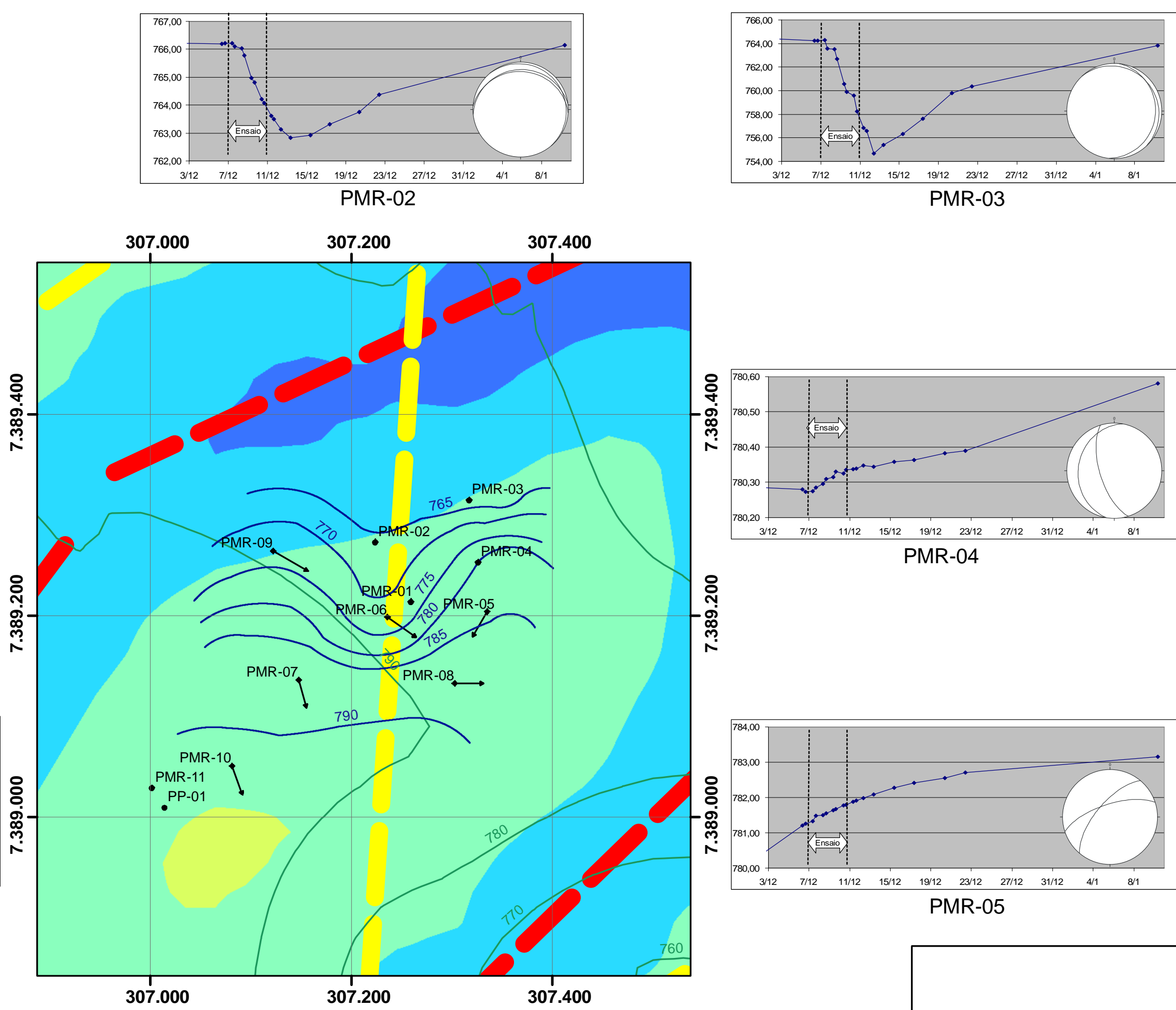

:

PMR-04

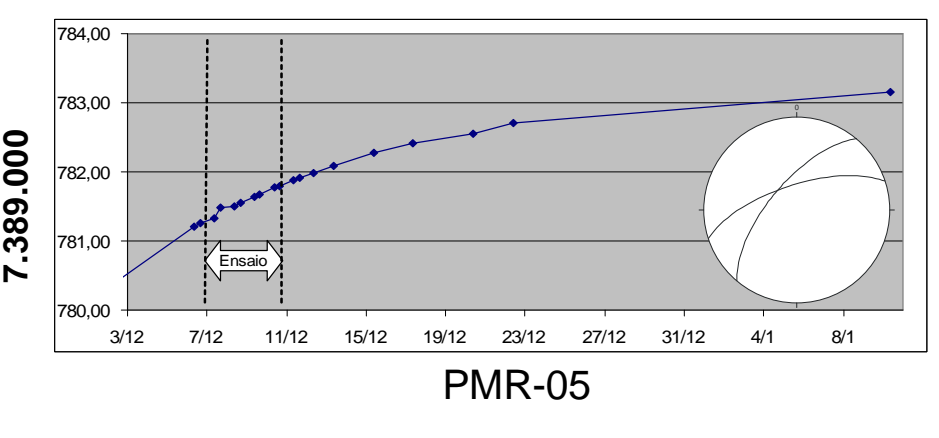

Hipsométrico

Altitude $(\mathrm{m})$

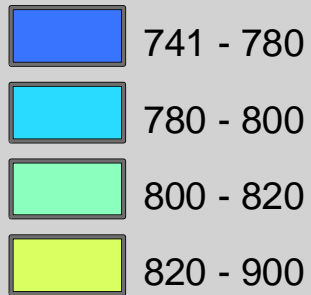

Lineamentos de isobase

Lineamentos de relevo

Isolinhas de base

Equipotenciais

Estereogramas - fraturas abertas nos filtros

Gráficos

Carga hidráulica $x$ tempo
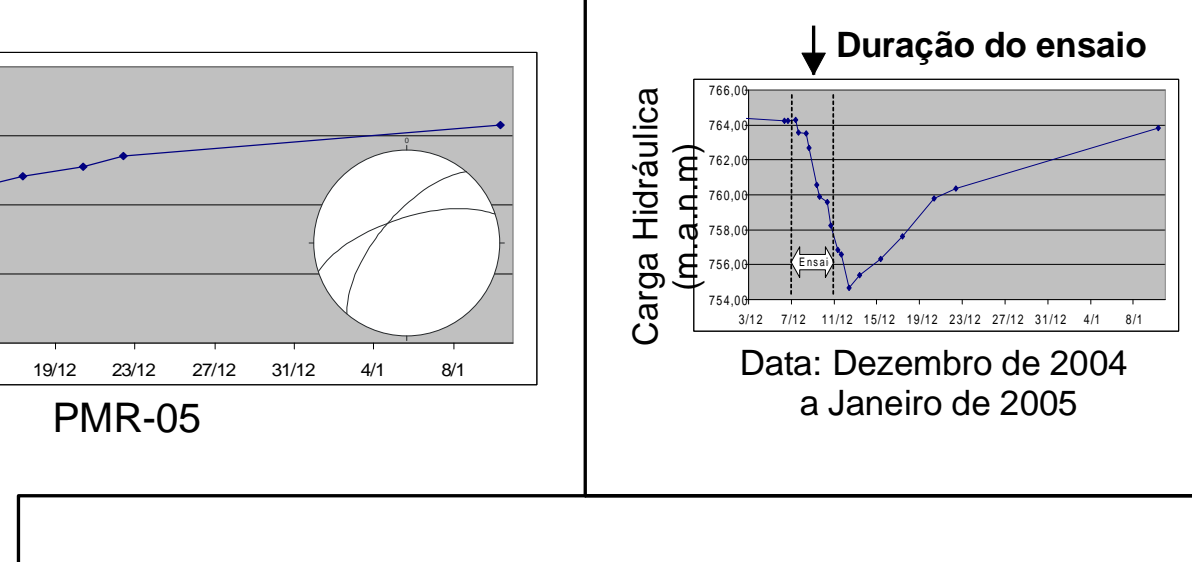
Figura 21 - Variações das cargas hidráulicas - área de detalhe A

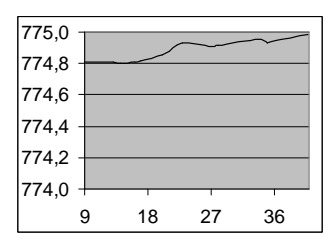

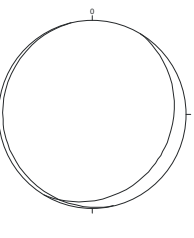

PMR-01 B
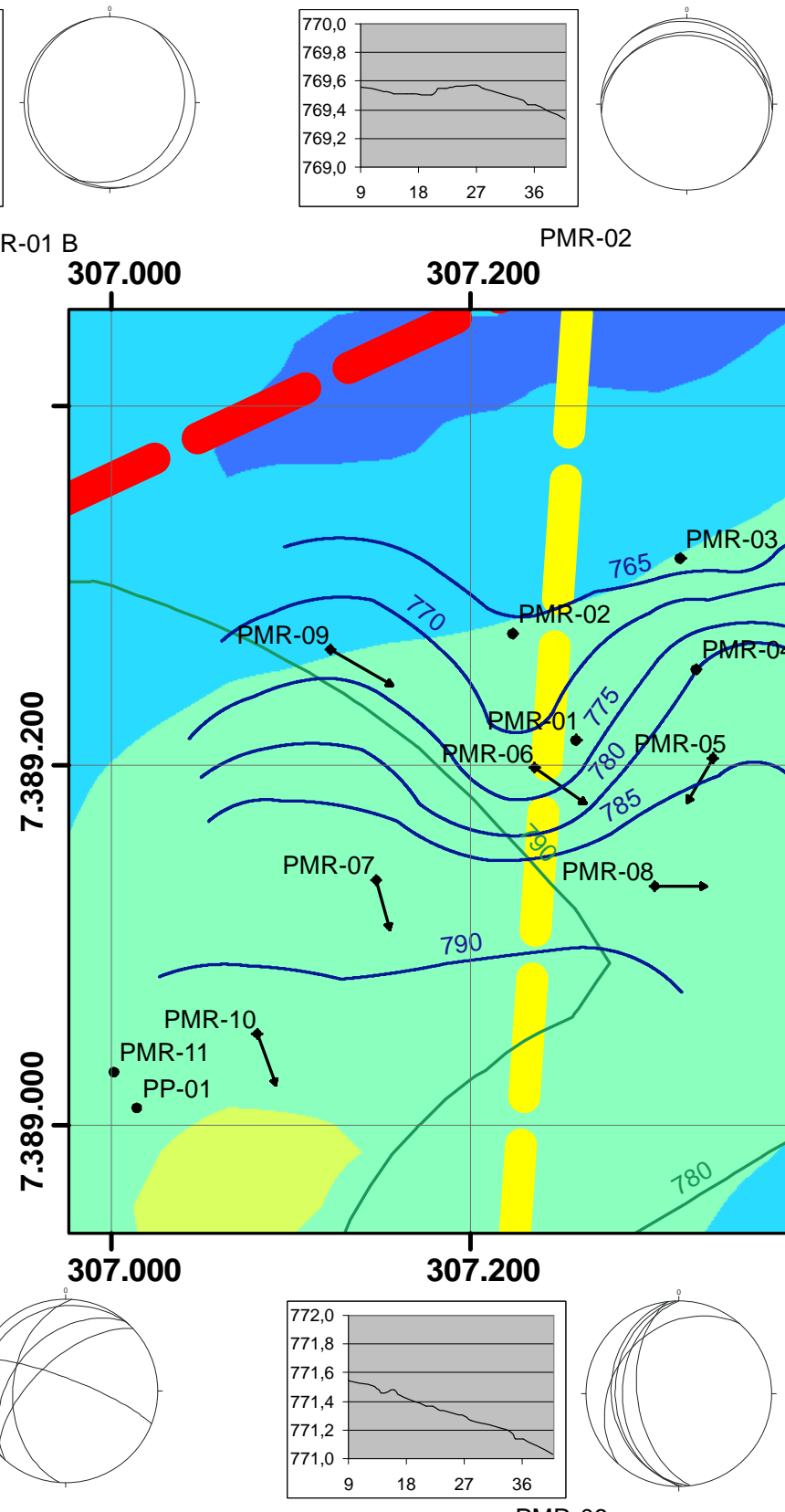

\section{PMR-07} 790

PMR-10
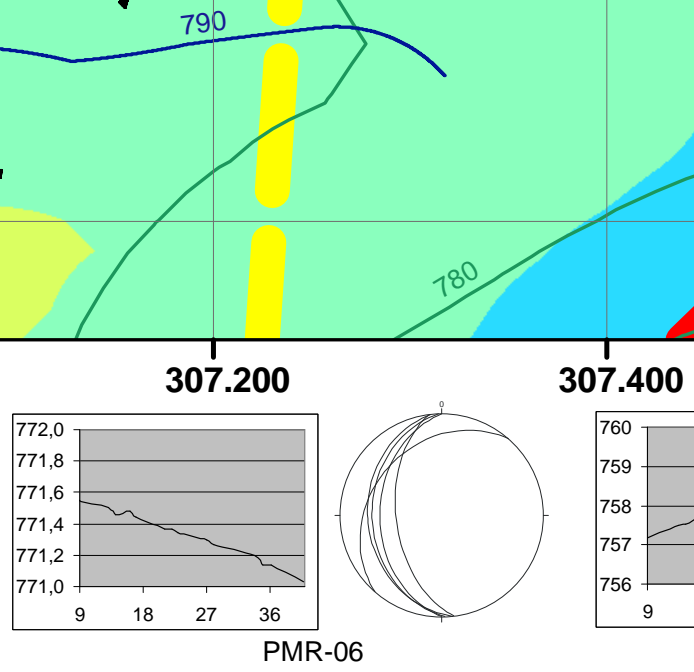
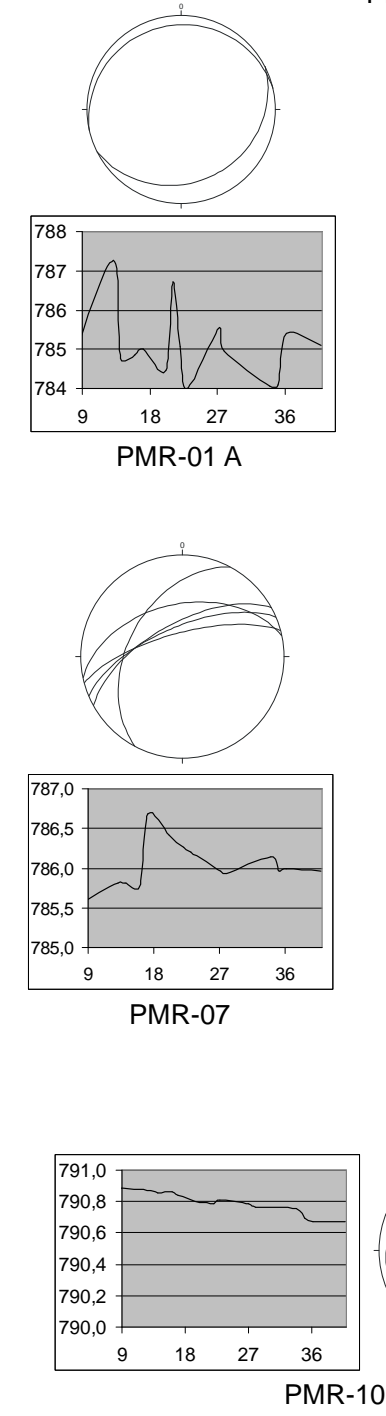

PMR-02

$\mathbf{3 0 7 . 2 0 0}$

\subsection{0}
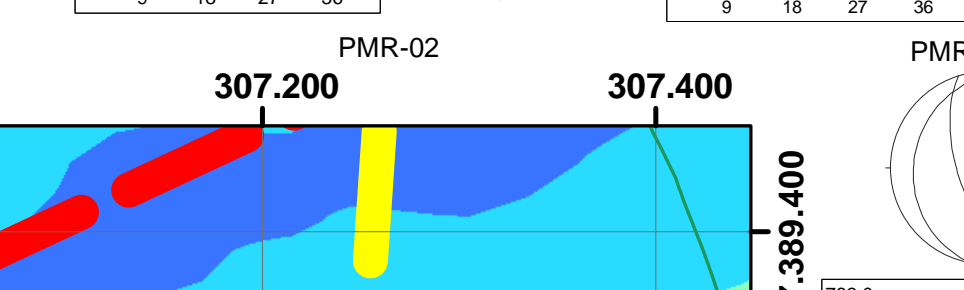

PMR-03

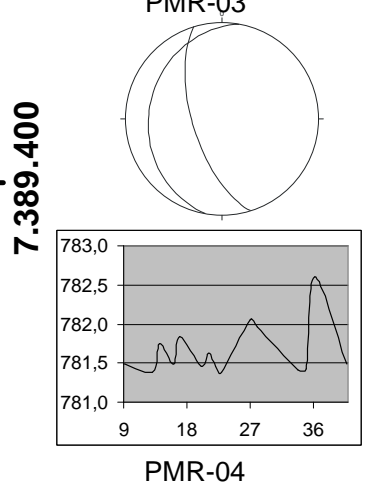

จे

$\stackrel{\infty}{\stackrel{\infty}{\infty}}$
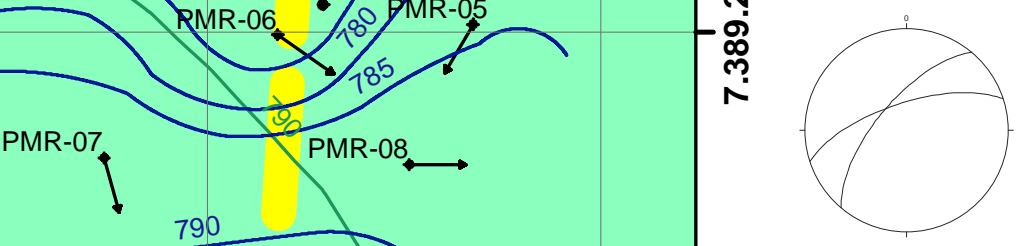

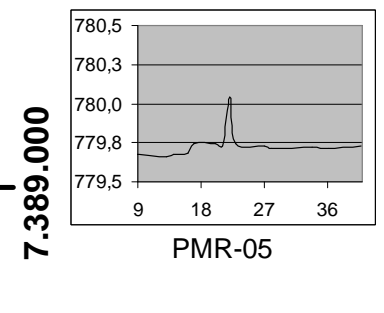

307.400

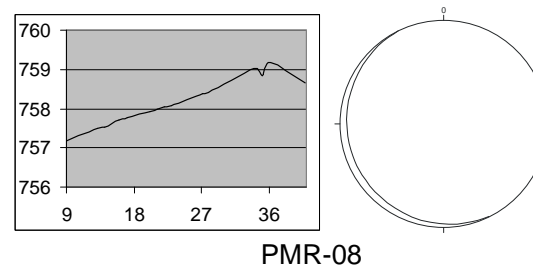

\section{Hipsométrico}

Altitude $(\mathrm{m})$

$\square 741-780$

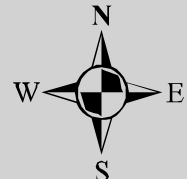

$780-800$

$800-820$

$820-900$

Lineamentos de isobase

Lineamentos de sombreamento de relevo

Isolinhas de base

Equipotenciais

Estereograma das fraturas abertas nos filtros PMR-09

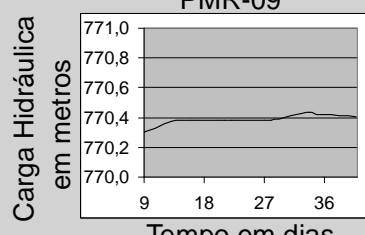

Gráficos de carga hidráulica em função do tempo (3/10/2006 até $13 / 11 / 2006)$

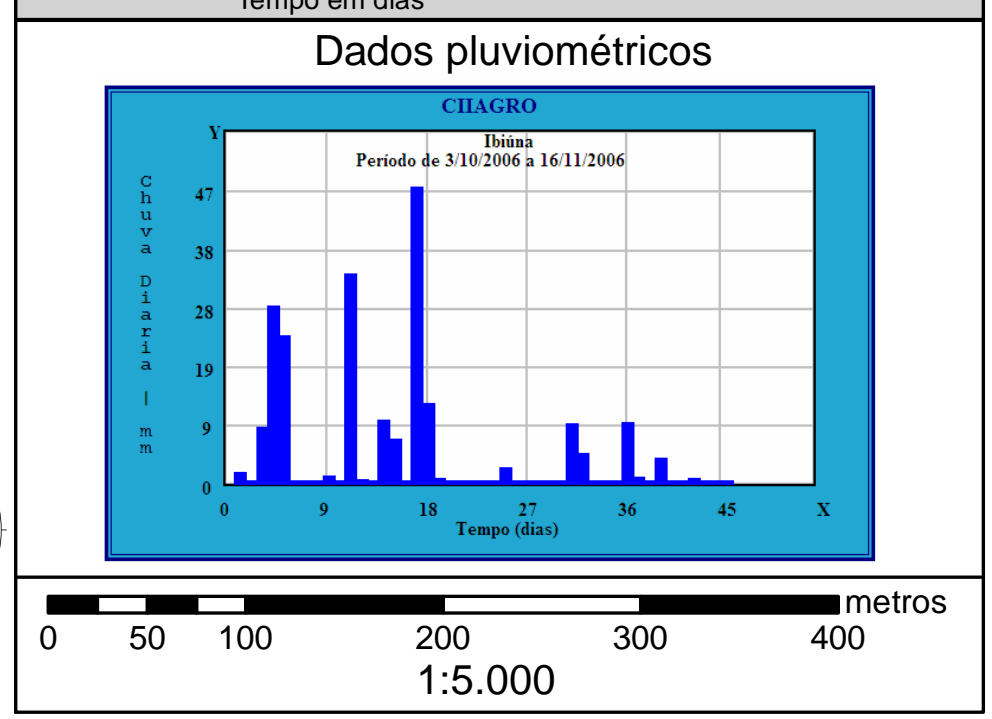


Figura 22 - Variações das cargas hidráulicas - área de detalhe B
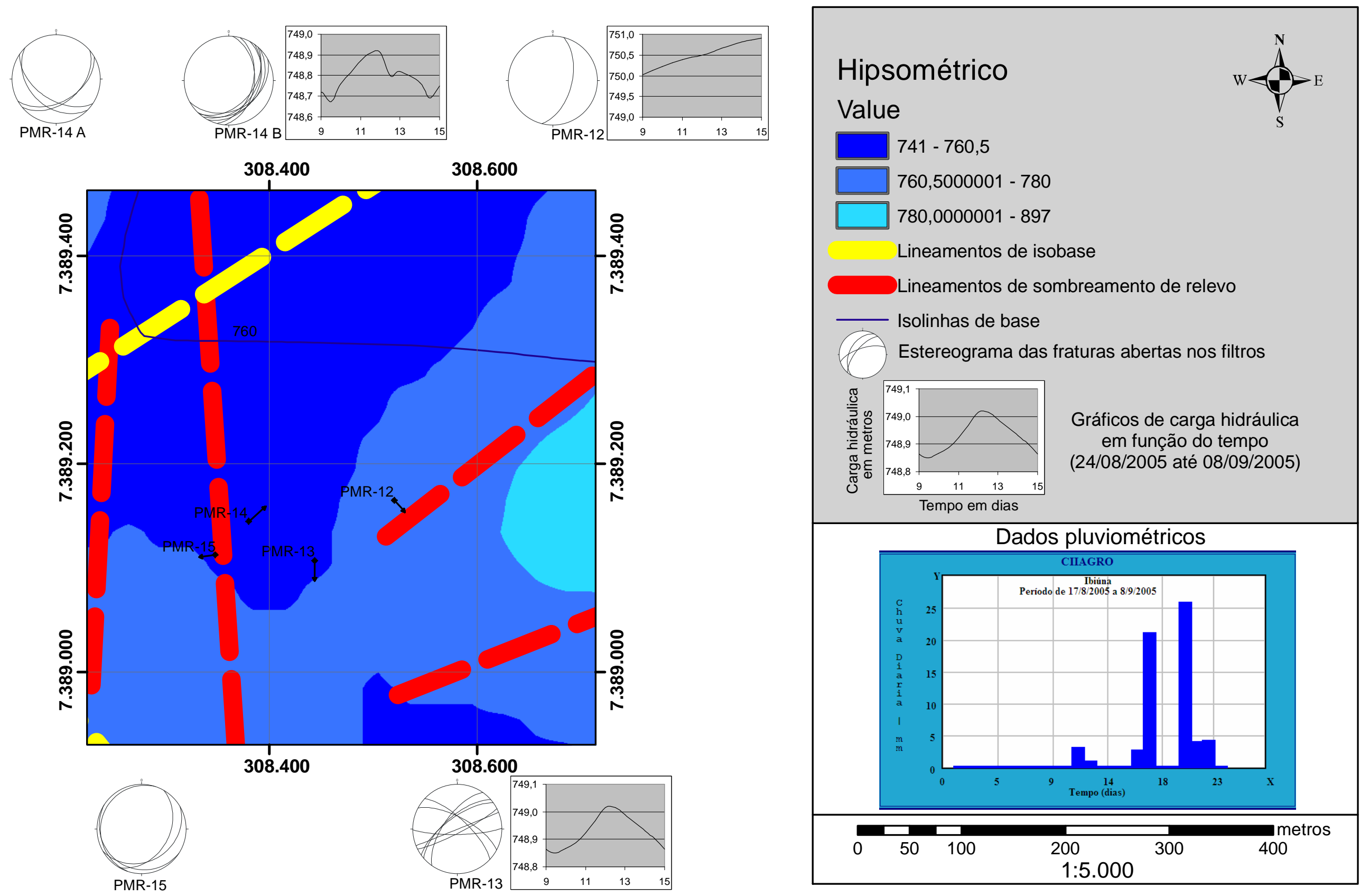
Figura 23 - Densidade de lineamentos NW-SE

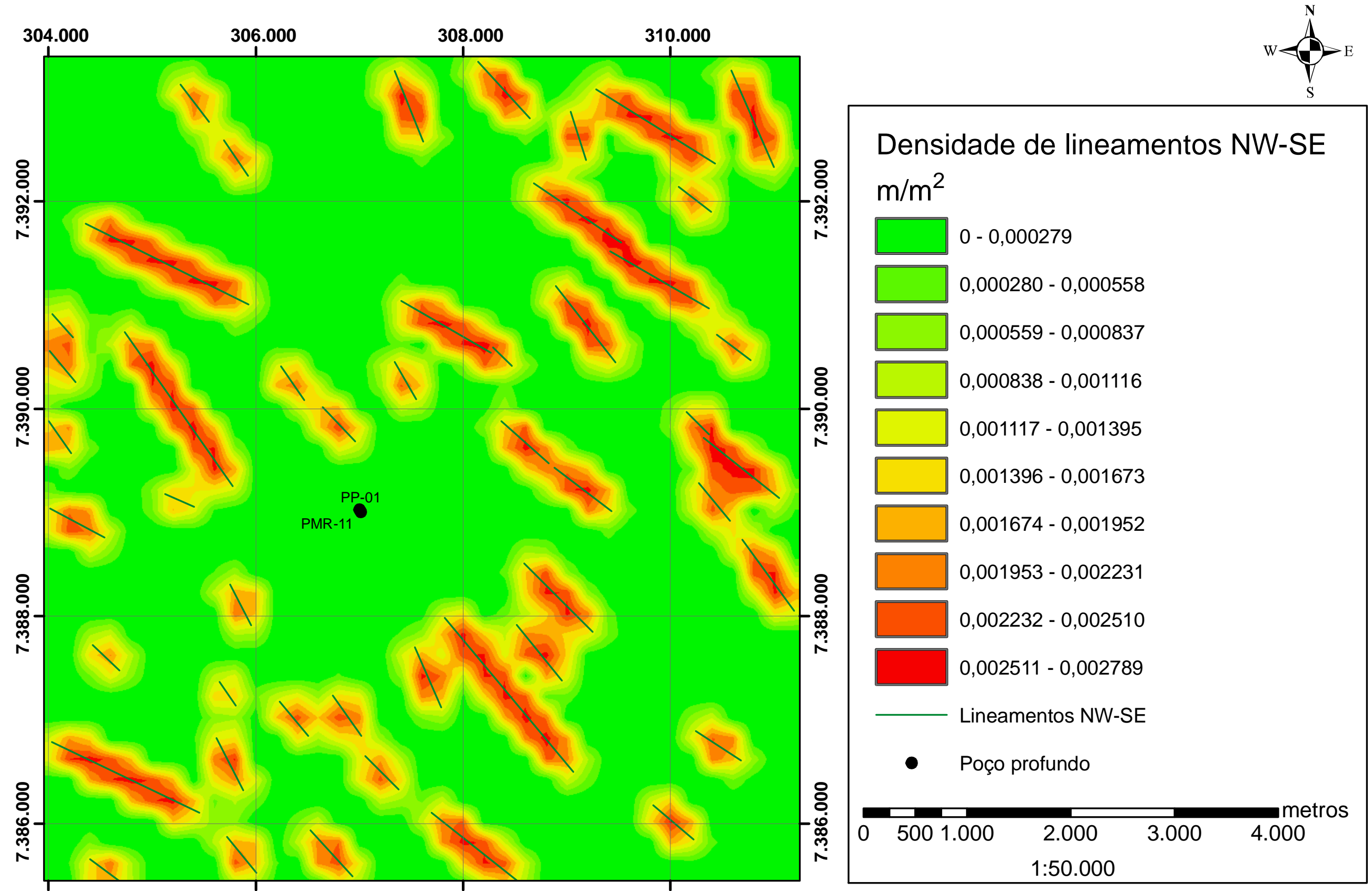




\section{Figura 24 - Densidade de lineamentos NE-SW}

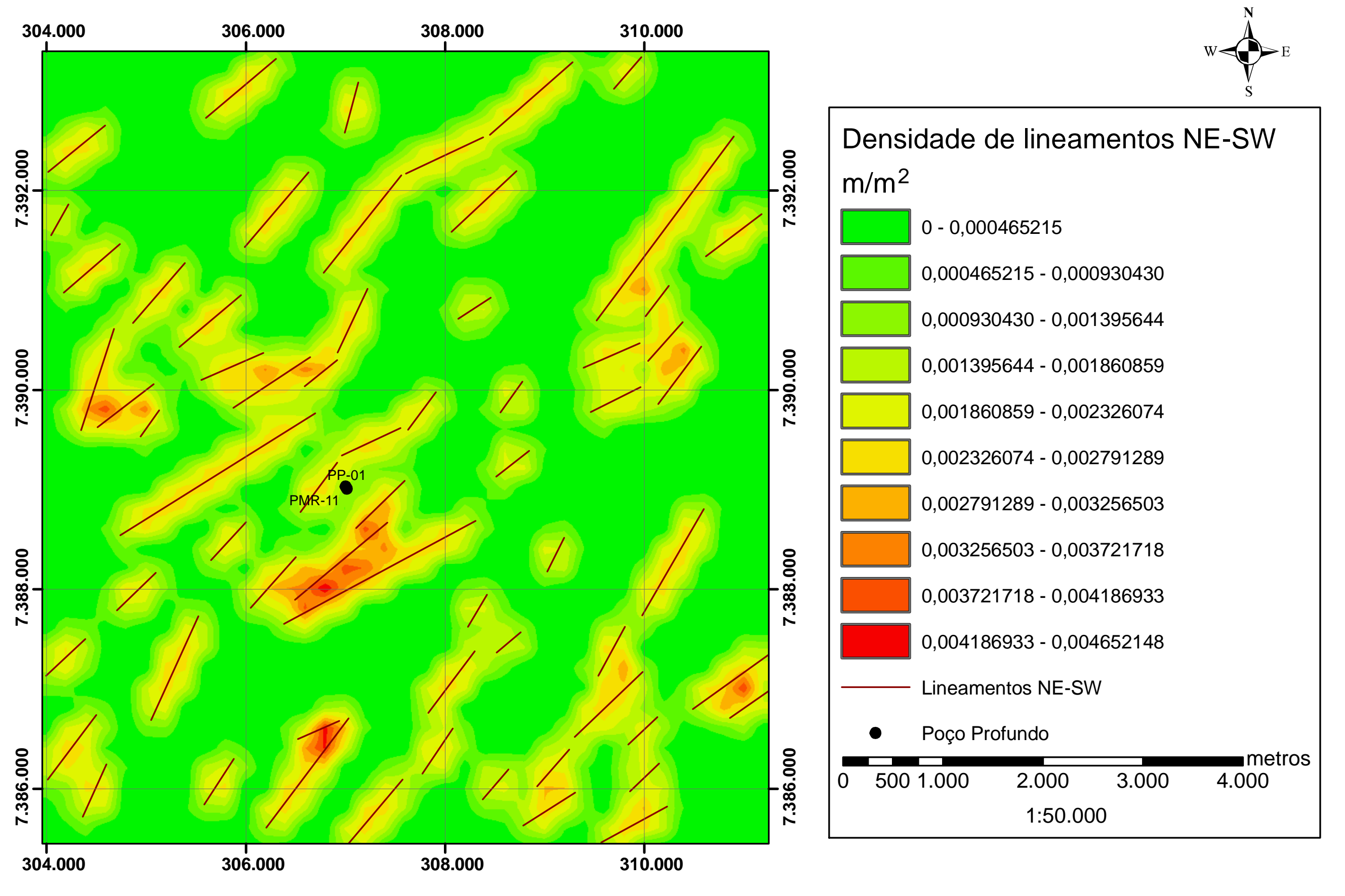


Figura 25 - Densidade de Lineamentos E-W

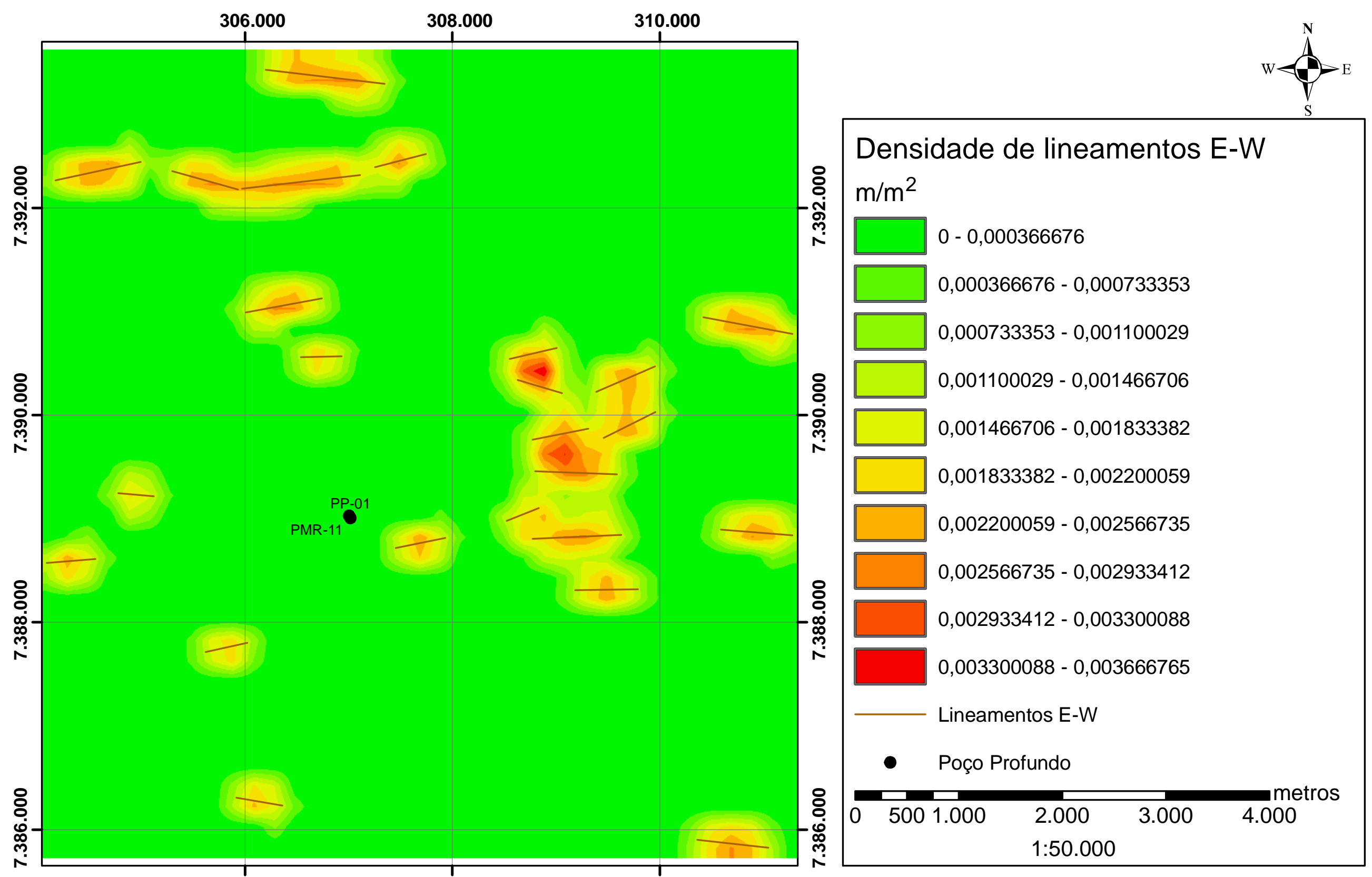


Figura 26 - Densidade de lineamentos N-S

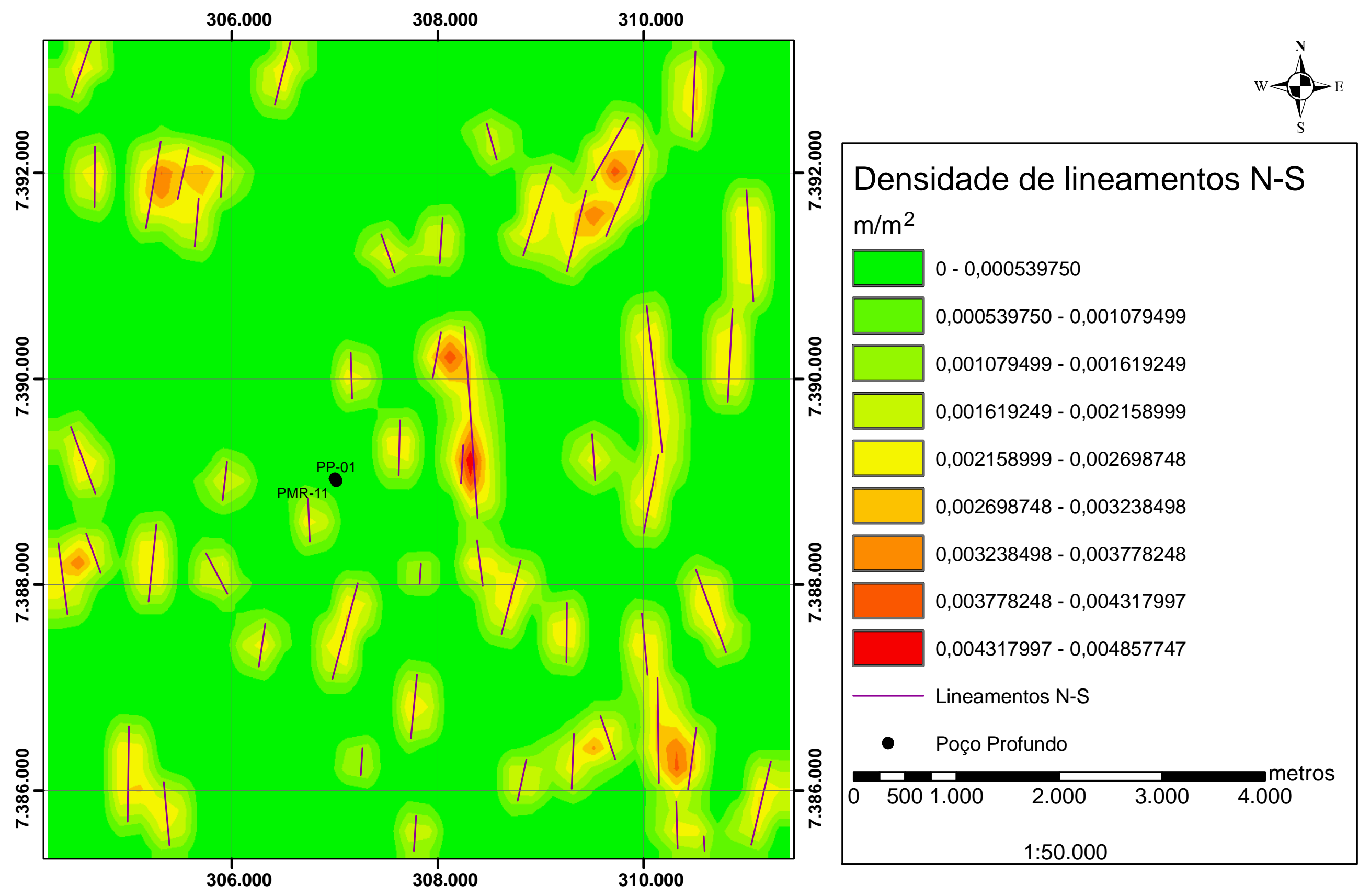




\section{Anexo II - Tabelas}

Tabela 1 - Estruturas de campo

Tabela 2 - Fraturas da área de detalhe A

Tabela 3 - Fraturas da área de detalhe B 


\begin{tabular}{|c|c|c|c|c|}
\hline Atitude (clar) & Mergulho & Tipo & Observação & Ponto \\
\hline 70 & 48 & $\mathrm{P}$ & & Ponto 1 \\
\hline 107 & 53 & $\mathrm{P}$ & & Ponto 1 \\
\hline 162 & 90 & $\mathrm{P}$ & & Ponto 1 \\
\hline 320 & 63 & $\mathrm{P}$ & & Ponto 1 \\
\hline 310 & 20 & $\mathrm{P}$ & & Ponto 1 \\
\hline 330 & 86 & $\mathrm{P}$ & consolidada & Ponto 1 \\
\hline 135 & 35 & $\mathrm{P}$ & & Ponto 1 \\
\hline 120 & 90 & $\mathrm{P}$ & & Ponto 1 \\
\hline 320 & 80 & $\mathrm{P}$ & proeminente & Ponto 1 \\
\hline 323 & 76 & $\mathrm{P}$ & perc. água & Ponto 1 \\
\hline 325 & 75 & $\mathrm{P}$ & & Ponto 1 \\
\hline 0 & 86 & $\mathrm{P}$ & & Ponto 1 \\
\hline 270 & 7 & $\mathrm{~L}$ & dextral & Ponto 1 \\
\hline 355 & 80 & $\mathrm{P}$ & falha & Ponto 1 \\
\hline 2 & 55 & $\mathrm{P}$ & falha & Ponto 1 \\
\hline 90 & 3 & $\mathrm{~L}$ & dextral & Ponto 1 \\
\hline 0 & 60 & $\mathrm{P}$ & zona milonitizada & Ponto 1 \\
\hline 260 & 80 & $p$ & & Ponto 2 \\
\hline 70 & 90 & $p$ & & Ponto 2 \\
\hline 90 & 80 & $p$ & & Ponto 2 \\
\hline 120 & 90 & $p$ & & Ponto 2 \\
\hline 100 & 90 & $p$ & veio feldspato & Ponto 2 \\
\hline 120 & 90 & $p$ & espelho & Ponto 2 \\
\hline 185 & 90 & $p$ & sistemática & Ponto 2 \\
\hline 90 & 90 & $p$ & sistemática & Ponto 2 \\
\hline 82 & 70 & $p$ & falha proemin. & Ponto 2 \\
\hline 315 & 45 & $p$ & foliação & Ponto 2 \\
\hline 140 & 20 & $p$ & foliação & Ponto 5 \\
\hline 250 & 90 & $p$ & plano c/ caulim & Ponto 5 \\
\hline 245 & 90 & $p$ & plano c/ caulim & Ponto 5 \\
\hline 345 & 70 & $p$ & camada máfica bi e mica dourada & Ponto 5 \\
\hline 69 & 15 & 1 & lineamento mineral & Ponto 5 \\
\hline 330 & 55 & $p$ & corpo feldspato & Ponto 5 \\
\hline 245 & 75 & $p$ & & Ponto 8 \\
\hline 247 & 80 & $p$ & & Ponto 8 \\
\hline 63 & 85 & $p$ & & Ponto 8 \\
\hline 330 & 70 & $p$ & falha 5 estrelas & Ponto 9 \\
\hline 325 & 90 & $p$ & & Ponto 9 \\
\hline 340 & 90 & $p$ & & Ponto 9 \\
\hline 230 & 85 & $p$ & & Ponto 10 \\
\hline 240 & 88 & $p$ & & Ponto 10 \\
\hline 115 & 90 & $p$ & & Ponto 12 \\
\hline 112 & 90 & $p$ & & Ponto 12 \\
\hline 330 & 55 & $p$ & sistemática & Ponto 13 \\
\hline 0 & 90 & $p$ & sistemática & Ponto 13 \\
\hline 125 & 83 & $p$ & & Ponto 13 \\
\hline 320 & 78 & $p$ & plano & Ponto 14 \\
\hline 348 & 38 & $p$ & foliação & Ponto 14 \\
\hline 350 & 40 & $p$ & foliação & Ponto 14 \\
\hline 340 & 90 & $p$ & plano & Ponto 14 \\
\hline 60 & 90 & $p$ & plano & Ponto 14 \\
\hline 220 & 85 & $p$ & plano & Ponto 14 \\
\hline 315 & 90 & $p$ & plano & Ponto 14 \\
\hline
\end{tabular}




\begin{tabular}{|c|c|c|c|c|}
\hline Atitude (clar) & Mergulho & Tipo & Observação & Ponto \\
\hline 315 & 65 & $\overline{p p}$ & plano & Ponto 14 \\
\hline 315 & 20 & $p$ & foliação & Ponto 15 \\
\hline 60 & 90 & $p$ & & Ponto 15 \\
\hline 75 & 79 & $p$ & & Ponto 15 \\
\hline 320 & 30 & $p$ & foliação & Ponto 16 \\
\hline 40 & 85 & $p$ & & Ponto 16 \\
\hline 55 & 80 & $p$ & & Ponto 16 \\
\hline 320 & 48 & $p$ & foliação & Ponto 16 \\
\hline 325 & 46 & $p$ & foliação & Ponto 16 \\
\hline 327 & 45 & $p$ & foliação & Ponto 16 \\
\hline 322 & 47 & $p$ & foliação & Ponto 16 \\
\hline 320 & 45 & $p$ & foliação & Ponto 16 \\
\hline 317 & 49 & $p$ & foliação & Ponto 16 \\
\hline 65 & 85 & $p$ & & Ponto 16 \\
\hline 320 & 35 & $p$ & foliação & Ponto 16 \\
\hline 335 & 25 & $p$ & foliação & Ponto 16 \\
\hline 120 & 90 & $p$ & & Ponto 16 \\
\hline 120 & 80 & $p$ & & Ponto 16 \\
\hline 118 & 80 & $p$ & & Ponto 16 \\
\hline 320 & 13 & $p$ & foliação & Ponto 16 \\
\hline 50 & 82 & $p$ & & Ponto 16 \\
\hline 150 & 65 & $p$ & falha & Ponto 16 \\
\hline 62 & 5 & 1 & estria & Ponto 16 \\
\hline 327 & 88 & $p$ & foliação & Ponto 16 \\
\hline 288 & 73 & $p$ & & Ponto 16 \\
\hline 332 & 64 & $p$ & foliação & Ponto 16 \\
\hline 290 & 72 & $p$ & & Ponto 16 \\
\hline 345 & 55 & $p$ & & Ponto 16 \\
\hline 170 & 85 & $p$ & conjugada - corta foliação & Ponto 16 \\
\hline 105 & 75 & $p$ & conjugada - corta foliação & Ponto 16 \\
\hline 354 & 42 & $p$ & & Ponto 16 \\
\hline 350 & 76 & $p$ & aplito milonitizado $\mathrm{c} / 50 \mathrm{~cm}$ & Ponto 16 \\
\hline 347 & 67 & $p$ & milonitiz. Feldspatos & Ponto 16 \\
\hline 135 & 62 & $p$ & conjugada - corta foliação & Ponto 16 \\
\hline 180 & 70 & $p$ & conjugada - corta foliação & Ponto 16 \\
\hline 110 & 53 & $p$ & conjugada - corta foliação & Ponto 16 \\
\hline 355 & 73 & $p$ & conjugada - corta foliação & Ponto 16 \\
\hline 63 & 88 & $p$ & grande continuidade lateral & Ponto 16 \\
\hline 275 & 42 & $p$ & & Ponto 16 \\
\hline 55 & 80 & $p$ & & Ponto 16 \\
\hline 315 & 82 & $p$ & & Ponto 16 \\
\hline 310 & 44 & $p$ & & Ponto 16 \\
\hline 45 & 81 & $p$ & grande continuidade lateral & Ponto 16 \\
\hline 315 & 58 & $p$ & & Ponto 16 \\
\hline 104 & 63 & $p$ & & Ponto 16 \\
\hline 310 & 90 & $p$ & plano mestre & Ponto 16 \\
\hline 145 & 45 & $p$ & sistemática & Ponto 16 \\
\hline 145 & 45 & $p$ & sistemática & Ponto 16 \\
\hline 145 & 45 & $p$ & sistemática & Ponto 16 \\
\hline 90 & 30 & $p$ & grande continuidade lateral & Ponto 16 \\
\hline 330 & 82 & $p$ & & Ponto 16 \\
\hline 350 & 67 & $\mathrm{p}$ & & Ponto 16 \\
\hline 340 & 40 & $p$ & & Ponto 16 \\
\hline 60 & 88 & $p$ & grande continuidade lateral & Ponto 16 \\
\hline
\end{tabular}




\begin{tabular}{|c|c|c|c|c|}
\hline Atitude (clar) & Mergulho & Tipo & Observação & Ponto \\
\hline 300 & 85 & $\bar{p}$ & & Ponto 16 \\
\hline 310 & 85 & $p$ & & Ponto 16 \\
\hline 295 & 48 & $p$ & & Ponto 16 \\
\hline 320 & 55 & $p$ & & Ponto 16 \\
\hline 340 & 70 & $p$ & & Ponto 16 \\
\hline 345 & 72 & $p$ & & Ponto 16 \\
\hline \begin{tabular}{l|l}
323 \\
\end{tabular} & 30 & $p$ & dique aplito-corpo leucogranítico & Ponto 16 \\
\hline 320 & 35 & $p$ & foliação & Ponto 16 \\
\hline 340 & 50 & $p$ & fratura proeminente & Ponto 16 \\
\hline 60 & 86 & $p$ & plano mestre & Ponto 16 \\
\hline 55 & 87 & $p$ & plano mestre & Ponto 16 \\
\hline 60 & 89 & $p$ & plano mestre & Ponto 16 \\
\hline 57 & 88 & $p$ & plano mestre & Ponto 16 \\
\hline \begin{tabular}{l|l}
63 \\
\end{tabular} & 86 & $p$ & plano mestre & Ponto 16 \\
\hline 170 & 53 & $p$ & conjugada - corta foliação & Ponto 16 \\
\hline 155 & 57 & $p$ & conjugada - corta foliação & Ponto 16 \\
\hline 105 & 47 & $\mathrm{p}$ & falha & Ponto 16 \\
\hline 97 & 46 & 1 & estria, inverso & Ponto 16 \\
\hline 64 & 85 & $p$ & preenchimento de caulim & Ponto 18 \\
\hline 180 & 70 & $p$ & & Ponto 18 \\
\hline 0 & 36 & $p$ & veio & Ponto 18 \\
\hline 32 & 89 & $p$ & & Ponto 18 \\
\hline 65 & 85 & $p$ & preenchimento de caulim & Ponto 18 \\
\hline 25 & 85 & $p$ & caulim & Ponto 18 \\
\hline$\frac{24}{30}$ & 87 & $p$ & plano & Ponto 18 \\
\hline 65 & 85 & $p$ & \multirow[b]{2}{*}{ Conjugadas } & Ponto 18 \\
\hline 30 & 87 & $p$ & & \begin{tabular}{|l} 
Ponto 18 \\
\end{tabular} \\
\hline 13 & 85 & $p$ & plano & Ponto 18 \\
\hline 283 & 7 & L & & Ponto 18 \\
\hline 28 & 82 & $p$ & & Ponto 18 \\
\hline 20 & 81 & $p$ & & Ponto 18 \\
\hline 128 & 30 & $p$ & trunca o sistema & Ponto 18 \\
\hline 270 & 70 & $p$ & & Ponto 18 \\
\hline 282 & 52 & $p$ & & Ponto 19 \\
\hline 185 & 85 & $p$ & & Ponto 19 \\
\hline 252 & 80 & $p$ & preenchimento & Ponto 19 \\
\hline 10 & 75 & $p$ & & Ponto 19 \\
\hline 180 & 60 & $p$ & & Ponto 19 \\
\hline 250 & 88 & $p$ & & Ponto 19 \\
\hline 300 & 67 & $p$ & rugosidade leve para cima & Ponto 20 \\
\hline 195 & 85 & $p$ & veio Qz cortado por fratura & Ponto 20 \\
\hline 310 & 42 & $p$ & veio Qz e feldspato & Ponto 20 \\
\hline 200 & 72 & $p$ & foto contato & Ponto 21 \\
\hline 212 & 65 & $p$ & & Ponto 21 \\
\hline 250 & 60 & $p$ & contato & Ponto 21 \\
\hline 280 & 89 & $p$ & & Ponto 21 \\
\hline 225 & 70 & $p$ & & Ponto 22 \\
\hline 205 & 80 & $p$ & & Ponto 22 \\
\hline 200 & 80 & $p$ & & Ponto 22 \\
\hline 5 & 60 & $p$ & & Ponto 22 \\
\hline 135 & 65 & $p$ & veio ou fratura preenchida & Ponto 22 \\
\hline 195 & 75 & $p$ & & Ponto 22 \\
\hline 95 & 30 & $p$ & veio ou fratura preenchida & Ponto 22 \\
\hline 30 & 78 & $\mathrm{p}$ & conjugada & Ponto 24 \\
\hline
\end{tabular}




\begin{tabular}{|c|c|c|c|c|}
\hline Atitude (clar) & Mergulho & Tipo & Observação & Ponto \\
\hline 235 & 75 & $\bar{p}$ & Normal-conjugada & Ponto 24 \\
\hline 30 & 78 & $p$ & conjugada & Ponto 24 \\
\hline 210 & 65 & $p$ & conjugada & Ponto 24 \\
\hline 120 & 65 & $p$ & falha foto lapiseira & Ponto 24 \\
\hline 255 & 68 & $p$ & & Ponto 24 \\
\hline 355 & 40 & $p$ & Foliação & Ponto 25 \\
\hline 80 & 80 & $p$ & preenchida negra & Ponto 25 \\
\hline 57 & 85 & $p$ & boa partição & Ponto 25 \\
\hline 348 & 40 & $p$ & preenchida caulim & Ponto 25 \\
\hline 310 & 45 & $p$ & preenchida caulim & Ponto 25 \\
\hline 155 & 50 & $p$ & Partição ruim - vermelha & Ponto 25 \\
\hline 250 & 80 & $p$ & amarelo & Ponto 25 \\
\hline 3 & 40 & $p$ & preto & Ponto 25 \\
\hline 215 & 60 & $p$ & foto & Ponto 25 \\
\hline 20 & 80 & $p$ & irregular-preto & Ponto 25 \\
\hline 10 & 70 & $p$ & & Ponto 25 \\
\hline 140 & 90 & $p$ & Foliação milonítica & Ponto 26 \\
\hline 165 & 50 & $p$ & veio caulim & Ponto 27 \\
\hline 60 & 82 & $p$ & boa partição-amarelo & Ponto 27 \\
\hline 55 & 89 & $p$ & boa partição-amarelo & Ponto 27 \\
\hline 247 & 73 & $p$ & & Ponto 27 \\
\hline 150 & 80 & $p$ & veio caulim & Ponto 27 \\
\hline 150 & 85 & $p$ & camada caulim & Ponto 27 \\
\hline 150 & 75 & $p$ & veio caulim & Ponto 27 \\
\hline 185 & 82 & $p$ & boa partição-amarelo & Ponto 28 \\
\hline 330 & 85 & $p$ & Corpo tabular caulim & Ponto 28 \\
\hline 202 & 75 & $p$ & amarelo partição ruim & Ponto 28 \\
\hline 160 & 65 & $p$ & negro // foliação & Ponto 28 \\
\hline 225 & 85 & $p$ & boa partição-preto & Ponto 29 \\
\hline 80 & 75 & $p$ & Preto irregular & Ponto 29 \\
\hline 150 & 85 & $p$ & Preto irregular de difícil partição & Ponto 30 \\
\hline 0 & 65 & $p$ & Preto irregular de difícil partição & Ponto 30 \\
\hline
\end{tabular}




\begin{tabular}{|c|c|c|c|c|c|}
\hline "Atitude (Clar) & Mergulho & & Profundidade & \multicolumn{2}{|c|}{ Observação } \\
\hline 347 & 11 & $\mathrm{P}$ & 37 & aberta & PMR-01 \\
\hline 153 & 23 & $\mathrm{P}$ & 38,5 & aberta & PMR-01 \\
\hline 212 & 3 & $\mathrm{P}$ & 44 & aberta & PMR-01 \\
\hline 121 & 16 & $\mathrm{P}$ & 48,7 & aberta & PMR-01 \\
\hline 257 & 5 & $\mathrm{P}$ & 47,4 & aberta & PMR-01 \\
\hline 10 & 78 & $\mathrm{P}$ & 28,6 & aberta & PMR-02 \\
\hline 23 & 7 & $\mathrm{P}$ & 28,7 & aberta & PMR-02 \\
\hline 0 & 77 & $\mathrm{P}$ & 30,4 & aberta & PMR-02 \\
\hline 359 & 77 & $\mathrm{P}$ & 30,4 & aberta & PMR-02 \\
\hline 4 & 21 & $\mathrm{P}$ & 34,9 & aberta & PMR-02 \\
\hline 354 & 17 & $\mathrm{P}$ & 35,1 & aberta & PMR-02 \\
\hline 50 & 6 & $\mathrm{P}$ & 37,7 & aberta & PMR-02 \\
\hline 237 & 5 & $\mathrm{P}$ & 24,6 & aberta & PMR-03 \\
\hline 334 & 17 & $\mathrm{P}$ & 26,8 & aberta & PMR-03 \\
\hline 47 & 9 & $\mathrm{P}$ & 40,7 & aberta & PMR-03 \\
\hline 96 & 14 & $\mathrm{P}$ & 44,8 & aberta & PMR-03 \\
\hline 253 & 65 & $\mathrm{P}$ & 46,8 & aberta & PMR-04 \\
\hline 280 & 25 & $\mathrm{P}$ & 50,9 & aberta & PMR-04 \\
\hline 342 & 68 & $\mathrm{P}$ & 41,9 & aberta & PMR-05 \\
\hline 310 & 66 & $\mathrm{P}$ & 49 & aberta & PMR-05 \\
\hline 299 & 43 & $\mathrm{P}$ & 51 & aberta & PMR-05 \\
\hline 73 & 43 & $\mathrm{P}$ & 27,5 & fechada & PMR-05 \\
\hline 1 & 75 & $\mathrm{P}$ & 28,5 & fechada & PMR-05 \\
\hline 14 & 83 & $\mathrm{P}$ & 28,7 & fechada & PMR-05 \\
\hline 11 & 67 & $\mathrm{P}$ & 30,2 & fechada & PMR-05 \\
\hline 10 & 71 & $\mathrm{P}$ & 36,1 & fechada & PMR-05 \\
\hline 19 & 79 & $\mathrm{P}$ & 36,2 & fechada & PMR-05 \\
\hline 14 & 63 & $\mathrm{P}$ & 37 & fechada & PMR-05 \\
\hline 6 & 66 & $\mathrm{P}$ & 38,32 & fechada & PMR-05 \\
\hline 9 & 67 & $\mathrm{P}$ & 38,4 & fechada & PMR-05 \\
\hline 344 & 51 & $\mathrm{P}$ & 38,7 & fechada & PMR-05 \\
\hline 326 & 57 & $\mathrm{P}$ & 39,6 & fechada & PMR-05 \\
\hline 343 & 59 & $\mathrm{P}$ & 39,7 & fechada & PMR-05 \\
\hline 337 & 71 & $\mathrm{P}$ & 43,9 & fechada & PMR-05 \\
\hline 352 & 61 & $\mathrm{P}$ & 44,4 & fechada & PMR-05 \\
\hline 332 & 57 & $\mathrm{P}$ & 49,2 & fechada & PMR-05 \\
\hline 317 & 55 & $\mathrm{P}$ & 49,6 & fechada & PMR-05 \\
\hline 339 & 39 & $\mathrm{P}$ & 51,6 & fechada & PMR-05 \\
\hline 254 & 12 & $\mathrm{P}$ & 42,2 & aberta & PMR-06 \\
\hline 256 & 31 & $\mathrm{P}$ & 42,9 & aberta & PMR-06 \\
\hline 276 & 23 & $\mathrm{P}$ & 43,2 & aberta & PMR-06 \\
\hline 69 & 32 & $\mathrm{P}$ & 46,4 & aberta & PMR-06 \\
\hline 268 & 32 & $\mathrm{P}$ & 58,1 & aberta & PMR-06 \\
\hline 264 & 28 & $\mathrm{P}$ & 58,2 & aberta & PMR-06 \\
\hline 263 & 53 & $\mathrm{P}$ & 59,1 & aberta & PMR-06 \\
\hline 270 & 39 & $\mathrm{P}$ & 59,2 & aberta & PMR-06 \\
\hline 311 & 30 & $\mathrm{P}$ & 59,3 & aberta & PMR-06 \\
\hline 271 & 52 & $\mathrm{P}$ & 40,6 & fechada & PMR-06 \\
\hline 197 & 35 & $\mathrm{P}$ & 45 & fechada & PMR-06 \\
\hline 38 & 77 & $\mathrm{P}$ & 47,7 & fechada & PMR-06 \\
\hline 42 & 54 & $\mathrm{P}$ & 48,3 & fechada & PMR-06 \\
\hline
\end{tabular}




\begin{tabular}{|c|c|c|c|c|c|}
\hline Atitude (Clar) & Mergulho & & Profundidade & \multicolumn{2}{|c|}{ Observação } \\
\hline 255 & 46 & $\mathrm{P}$ & 49,2 & fechada & PMR-06 \\
\hline 253 & 27 & $\mathrm{P}$ & 50,8 & fechada & PMR-06 \\
\hline 266 & 77 & $\mathrm{P}$ & 54,6 & fechada & PMR-06 \\
\hline 306 & 33 & $\mathrm{P}$ & 55,7 & fechada & PMR-06 \\
\hline 227 & 35 & $\mathrm{P}$ & 56,1 & fechada & PMR-06 \\
\hline 221 & 69 & $\mathrm{P}$ & 56,4 & fechada & PMR-06 \\
\hline 27 & 40 & $\mathrm{P}$ & 61,5 & fechada & PMR-06 \\
\hline 13 & 21 & $\mathrm{P}$ & 62 & fechada & PMR-06 \\
\hline 334 & 6 & $\mathrm{P}$ & 63,3 & fechada & PMR-06 \\
\hline 265 & 50 & $\mathrm{P}$ & 65,1 & fechada & PMR-06 \\
\hline 306 & 13 & $\mathrm{P}$ & 68 & fechada & PMR-06 \\
\hline 294 & 41 & $\mathrm{P}$ & 28,5 & fechada & PMR-07 \\
\hline 289 & 58 & $\mathrm{P}$ & 28,6 & fechada & PMR-07 \\
\hline 292 & 47 & $\mathrm{P}$ & 40,1 & fechada & PMR-07 \\
\hline 291 & 52 & $\mathrm{P}$ & 43,7 & fechada & PMR-07 \\
\hline 296 & 46 & $\mathrm{P}$ & 44,6 & fechada & PMR-07 \\
\hline 292 & 50 & $\mathrm{P}$ & 46,2 & fechada & PMR-07 \\
\hline 293 & 47 & $\mathrm{P}$ & 47,3 & fechada & PMR-07 \\
\hline 269 & 44 & $\mathrm{P}$ & 53,8 & fechada & PMR-07 \\
\hline 298 & 45 & $\mathrm{P}$ & 48,2 & aberta & PMR-07 \\
\hline 345 & 71 & $\mathrm{P}$ & 50,9 & aberta & PMR-07 \\
\hline 348 & 47 & $\mathrm{P}$ & 51,1 & aberta & PMR-07 \\
\hline 337 & 66 & $\mathrm{P}$ & 51,2 & aberta & PMR-07 \\
\hline 331 & 63 & $\mathrm{P}$ & 51,4 & aberta & PMR-07 \\
\hline 284 & 37 & $\mathrm{P}$ & 56,4 & aberta & PMR-07 \\
\hline 244 & 7,8 & $\mathrm{P}$ & 57,2 & aberta & PMR-08 \\
\hline 240 & 20,7 & $\mathrm{P}$ & 44,8 & aberta & PMR-08 \\
\hline 264 & 10,5 & $\mathrm{P}$ & 43,2 & aberta & PMR-08 \\
\hline 247 & 29,7 & $\mathrm{P}$ & 41,3 & aberta & PMR-08 \\
\hline 308 & 20,5 & $\mathrm{P}$ & 37,1 & aberta & PMR-08 \\
\hline 287 & 19,2 & $\mathrm{P}$ & 34,3 & aberta & PMR-08 \\
\hline 232 & 30 & $\mathrm{P}$ & 34,1 & aberta & PMR-08 \\
\hline 237 & 29 & $\mathrm{P}$ & 61,2 & fechada & PMR-08 \\
\hline 218 & 20,2 & $\mathrm{P}$ & 61,0 & fechada & PMR-08 \\
\hline 223 & 70,6 & $\mathrm{P}$ & 57,9 & fechada & PMR-08 \\
\hline 226 & 64,2 & $\mathrm{P}$ & 57,8 & fechada & PMR-08 \\
\hline 220 & 66,9 & $\mathrm{P}$ & 56,2 & fechada & PMR-08 \\
\hline 310 & 55,6 & $\mathrm{P}$ & 53,1 & fechada & PMR-08 \\
\hline 221 & 63,7 & $\mathrm{P}$ & 52,4 & fechada & PMR-08 \\
\hline 312 & 53,4 & $\mathrm{P}$ & 52,3 & fechada & $\begin{array}{l}\text { PMR-08 } \\
\text {. }\end{array}$ \\
\hline 271 & 85,7 & $\mathrm{P}$ & 50,2 & fechada & PMR-08 \\
\hline 259 & 29,5 & $\mathrm{P}$ & 40,1 & fechada & PMR-08 \\
\hline 241 & 21,5 & $\mathrm{P}$ & 37,8 & fechada & PMR-08 \\
\hline 340 & 40 & $\mathrm{P}$ & 76,6 & fechada & PMR-09 \\
\hline 342 & 48 & $\mathrm{P}$ & 76,3 & fechada & PMR-09 \\
\hline 331 & 40 & $\mathrm{P}$ & 76,2 & fechada & PMR-09 \\
\hline 325 & 49 & $\mathrm{P}$ & 75,0 & fechada & PMR-09 \\
\hline 305 & 51 & $\mathrm{P}$ & 74,1 & fechada & PMR-09 \\
\hline 319 & 49 & $\mathrm{P}$ & 71,1 & fechada & PMR-09 \\
\hline 320 & 48 & $\mathrm{P}$ & 70,0 & fechada & PMR-09 \\
\hline 311 & 45 & $\mathrm{P}$ & 67,5 & fechada & PMR-09 \\
\hline
\end{tabular}




\begin{tabular}{|c|c|c|c|c|c|}
\hline Atitude (Clar) & Mergulho & & Profundidade & \multicolumn{2}{|c|}{ Observação } \\
\hline 342 & 53 & $\mathrm{P}$ & 66,2 & fechada & PMR-09 \\
\hline 333 & 38 & $\mathrm{P}$ & 63,5 & fechada & PMR-09 \\
\hline 317 & 34 & $\mathrm{P}$ & 63,0 & fechada & PMR-09 \\
\hline 347 & 41 & $\mathrm{P}$ & 62,6 & fechada & PMR-09 \\
\hline 328 & 36 & $\mathrm{P}$ & 61,9 & fechada & PMR-09 \\
\hline 340 & 41 & $\mathrm{P}$ & 61,4 & fechada & PMR-09 \\
\hline 336 & 43 & $\mathrm{P}$ & 61,1 & fechada & PMR-09 \\
\hline 325 & 41 & $\mathrm{P}$ & 59,2 & fechada & PMR-09 \\
\hline 310 & 43 & $\mathrm{P}$ & 58,7 & fechada & PMR-09 \\
\hline 355 & 47 & $\mathrm{P}$ & 58,6 & fechada & PMR-09 \\
\hline 336 & 55 & $\mathrm{P}$ & 56,7 & fechada & PMR-09 \\
\hline 298 & 45 & $\mathrm{P}$ & 54,9 & fechada & PMR-09 \\
\hline 345 & 27 & $\mathrm{P}$ & 54,8 & fechada & PMR-09 \\
\hline 333 & 39 & $\mathrm{P}$ & 54,4 & fechada & PMR-09 \\
\hline 337 & 44 & $\mathrm{P}$ & 53,5 & fechada & PMR-09 \\
\hline 329 & 35 & $\mathrm{P}$ & 52,9 & fechada & PMR-09 \\
\hline 344 & 46 & $\mathrm{P}$ & 51,8 & fechada & PMR-09 \\
\hline 333 & 48 & $\mathrm{P}$ & 51,0 & fechada & PMR-09 \\
\hline 333 & 46 & $\mathrm{P}$ & 50,5 & fechada & PMR-09 \\
\hline 344 & 41 & $\mathrm{P}$ & 49,4 & fechada & PMR-09 \\
\hline 335 & 50 & $\mathrm{P}$ & 48,7 & fechada & PMR-09 \\
\hline 341 & 44 & $\mathrm{P}$ & 47,7 & fechada & PMR-09 \\
\hline 347 & 40 & $\mathrm{P}$ & 46,7 & fechada & PMR-09 \\
\hline 322 & 43 & $\mathrm{P}$ & 45,5 & fechada & PMR-09 \\
\hline 347 & 52 & $\mathrm{P}$ & 44,1 & fechada & PMR-09 \\
\hline 324 & 49 & $\mathrm{P}$ & 43,6 & fechada & $\begin{array}{l}\text { PMR-09 } \\
\end{array}$ \\
\hline 312 & 48 & $\mathrm{P}$ & 42,5 & fechada & PMR-09 \\
\hline 340 & 49 & $\mathrm{P}$ & 41,7 & fechada & PMR-09 \\
\hline 315 & 49 & $\mathrm{P}$ & 41,6 & fechada & PMR-09 \\
\hline 331 & 46 & $\mathrm{P}$ & 41,0 & fechada & PMR-09 \\
\hline 330 & 52 & $\mathrm{P}$ & 40,0 & fechada & PMR-09 \\
\hline 323 & 34 & $\mathrm{P}$ & 39,5 & fechada & PMR-09 \\
\hline 324 & 43 & $\mathrm{P}$ & 39,0 & fechada & PMR-09 \\
\hline 354 & 37 & $\mathrm{P}$ & 38,2 & fechada & PMR-09 \\
\hline 352 & 44 & $\mathrm{P}$ & 37,0 & fechada & PMR-09 \\
\hline 328 & 46 & $\mathrm{P}$ & 36,8 & fechada & PMR-09 \\
\hline 353 & 39 & $\mathrm{P}$ & 36,2 & fechada & PMR-09 \\
\hline 340 & 51 & $\mathrm{P}$ & 34,6 & fechada & PMR-09 \\
\hline 317 & 62 & $\mathrm{P}$ & 55,9 & abertas & PMR-10 \\
\hline 311 & 41 & $\mathrm{P}$ & 53,7 & abertas & PMR-10 \\
\hline 314 & 11 & $\mathrm{P}$ & 53,6 & abertas & PMR-10 \\
\hline 274 & 42 & $\mathrm{P}$ & 53,5 & abertas & PMR-10 \\
\hline 21 & 79 & $\mathrm{P}$ & 53,1 & abertas & PMR-10 \\
\hline 59 & 50 & $\mathrm{P}$ & 33,9 & abertas & PMR-10 \\
\hline 246 & 40 & $\mathrm{P}$ & 32,3 & abertas & PMR-10 \\
\hline 258 & 43 & $\mathrm{P}$ & 58,0 & fechadas & PMR-10 \\
\hline 299 & 56 & $\mathrm{P}$ & 56,5 & fechadas & PMR-10 \\
\hline 245 & 43 & $\mathrm{P}$ & 54,5 & fechadas & PMR-10 \\
\hline 251 & 43 & $\mathrm{P}$ & 53,9 & fechadas & PMR-10 \\
\hline 234 & 31 & $\mathrm{P}$ & 52,3 & fechadas & PMR-10 \\
\hline 213 & 28 & $\mathrm{P}$ & 50,9 & fechadas & PMR-10 \\
\hline
\end{tabular}




\begin{tabular}{||c|c|c|c|c|c||}
\hline Atitude (Clar) & Mergulho & & Profundidade & \multicolumn{2}{|c||}{ Observação } \\
\hline \hline 234 & 38 & $\mathrm{P}$ & 50,1 & fechadas & PMR-10 \\
\hline 240 & 41 & $\mathrm{P}$ & 48,4 & fechadas & PMR-10 \\
\hline 214 & 41 & $\mathrm{P}$ & 43,4 & fechadas & PMR-10 \\
\hline 214 & 32 & $\mathrm{P}$ & 42,7 & fechadas & PMR-10 \\
\hline 261 & 31 & $\mathrm{P}$ & 39,9 & fechadas & PMR-10 \\
\hline 252 & 27 & $\mathrm{P}$ & 37,2 & fechadas & PMR-10 \\
\hline 234 & 32 & $\mathrm{P}$ & 34,4 & fechadas & PMR-10 \\
\hline 262 & 45 & $\mathrm{P}$ & 33,1 & fechadas & PMR-10 \\
\hline
\end{tabular}




\begin{tabular}{|c|c|c|c|c|c|}
\hline "Atitude (Clar) & Mergulho & & Profundidade & \multicolumn{2}{|c|}{ Observação } \\
\hline 302 & 36,6 & \begin{tabular}{|l|}
$\mathrm{P}$ \\
\end{tabular} & 23,9 & Fechada & $\overline{\mid P M R-12}$ \\
\hline 72 & 62,7 & $\mathrm{P}$ & 17,1 & Fechada & PMR-12 \\
\hline 319 & 14,4 & $\mathrm{P}$ & 8,4 & Fechada & PMR-12 \\
\hline 104 & 54,7 & $\mathrm{P}$ & 18,4 & Aberta & PMR-12 \\
\hline 345 & 36,6 & $\mathrm{P}$ & 7,1 & Aberta & PMR-12 \\
\hline 316 & 45,3 & $\mathrm{P}$ & 6,6 & Aberta & PMR-12 \\
\hline 212 & 84,5 & $\mathrm{P}$ & 36,2 & Fechada & PMR-13 \\
\hline 29 & 62,7 & $\mathrm{P}$ & 34,0 & Fechada & PMR-13 \\
\hline 188 & 22,6 & \begin{tabular}{|l|}
$P$ \\
\end{tabular} & 31,5 & Fechada & PMR-13 \\
\hline 233 & 40 & $\mathrm{P}$ & 30,7 & Fechada & PMR-13 \\
\hline 319 & 75,5 & $\mathrm{P}$ & 30,4 & Fechada & PMR-13 \\
\hline 48 & 67,8 & $\mathrm{P}$ & 29,7 & Fechada & PMR-13 \\
\hline 285 & 42,5 & $\mathrm{P}$ & 23,2 & Fechada & PMR-13 \\
\hline 179 & 79,8 & $\mathrm{P}$ & 34,4 & Aberta & PMR-13 \\
\hline 28 & 68,7 & $\mathrm{P}$ & 34,0 & Aberta & PMR-13 \\
\hline 319 & 66,5 & $\mathrm{P}$ & 33,5 & Aberta & PMR-13 \\
\hline 153 & 82,5 & $\mathrm{P}$ & 33,3 & Aberta & PMR-13 \\
\hline 158 & 89,4 & $\mathrm{P}$ & 30,9 & Aberta & PMR-13 \\
\hline 305 & 64,6 & $\mathrm{P}$ & 30,1 & Aberta & PMR-13 \\
\hline 43 & 71,9 & $\mathrm{P}$ & 29,7 & Aberta & PMR-13 \\
\hline 324 & 69 & $\mathrm{P}$ & 29,1 & Aberta & PMR-13 \\
\hline 299 & 56 & $\mathrm{P}$ & 25,4 & Aberta & PMR-13 \\
\hline 27 & 79 & $\mathrm{P}$ & 24,4 & Aberta & PMR-13 \\
\hline 18 & 72,6 & $\mathrm{P}$ & 24,3 & Aberta & PMR-13 \\
\hline 6 & 78,2 & $\mathrm{P}$ & 24,2 & Aberta & PMR-13 \\
\hline 14 & 78,9 & $\mathrm{P}$ & 24,1 & Aberta & PMR-13 \\
\hline 134 & 54,9 & $\mathrm{P}$ & 41,8 & Fechada & PMR-14 \\
\hline 139 & 36,8 & $\mathrm{P}$ & 41,7 & Fechada & PMR-14 \\
\hline 127 & 32,9 & $\mathrm{P}$ & 34,6 & Fechada & PMR-14 \\
\hline 105 & 44,5 & $\mathrm{P}$ & 40,3 & Aberta & PMR-14 \\
\hline 125 & 37,7 & $\mathrm{P}$ & 40,2 & Aberta & PMR-14 \\
\hline 95 & 41,6 & $\mathrm{P}$ & 39,9 & Aberta & PMR-14 \\
\hline 118 & 32,1 & $\mathrm{P}$ & 38,3 & Aberta & PMR-14 \\
\hline 151 & 32,7 & $\mathrm{P}$ & 37,7 & Aberta & PMR-14 \\
\hline 134 & 29,8 & $\mathrm{P}$ & 37,6 & Aberta & PMR-14 \\
\hline 131 & 43,5 & $\mathrm{P}$ & 37,2 & Aberta & PMR-14 \\
\hline 27 & 83,1 & $\mathrm{P}$ & 35,6 & Aberta & PMR-14 \\
\hline 136 & 35,2 & $\mathrm{P}$ & 34,1 & Aberta & PMR-14 \\
\hline 101 & 44,1 & $\mathrm{P}$ & 33,8 & Aberta & PMR-14 \\
\hline 214 & 51,7 & $\mathrm{P}$ & 32,9 & Aberta & PMR-14 \\
\hline 225 & 37,2 & $\mathrm{P}$ & 32,7 & Aberta & PMR-14 \\
\hline 150 & 46,5 & $\mathrm{P}$ & 30,7 & Aberta & PMR-14 \\
\hline 140 & 44 & $\mathrm{P}$ & 30,6 & Aberta & PMR-14 \\
\hline 170,6 & 8,3 & $\mathrm{P}$ & 25,2 & Aberta & PMR-14 \\
\hline 107 & 5,6 & $\mathrm{P}$ & 29,7 & Fechada & PMR-15 \\
\hline 111 & 48,6 & $\mathrm{P}$ & 28,2 & Fechada & PMR-15 \\
\hline 191 & 8,4 & $\mathrm{P}$ & 27,2 & Fechada & PMR-15 \\
\hline 241 & 35,4 & $\mathrm{P}$ & 26,9 & Fechada & PMR-15 \\
\hline 18 & 77,1 & $\mathrm{P}$ & 26,5 & Fechada & PMR-15 \\
\hline 213 & 10,8 & $\mathrm{P}$ & 27,8 & Aberta & PMR-15 \\
\hline 288 & 8,9 & $\mathrm{P}$ & 27,5 & Aberta & PMR-15 \\
\hline
\end{tabular}




\begin{tabular}{||c|c|c|c|c|c||}
\hline Atitude (Clar) & Mergulho & & Profundidade & \multicolumn{2}{|c|}{ Observação } \\
\hline \hline 120 & 37,5 & $\mathrm{P}$ & 25,9 & Aberta & PMR-15 \\
\hline 150 & 27,3 & $\mathrm{P}$ & 25,6 & Aberta & PMR-15 \\
\hline 81 & 78,5 & $\mathrm{P}$ & 18,0 & Aberta & PMR-15 \\
\hline 79 & 74,1 & $\mathrm{P}$ & 17,8 & Aberta & PMR-15 \\
\hline 70 & 56,5 & $\mathrm{P}$ & 16,2 & Aberta & PMR-15 \\
\hline 96 & 46 & $\mathrm{P}$ & 15,9 & Aberta & PMR-15 \\
\hline 77 & 88 & $\mathrm{P}$ & 14,9 & Aberta & PMR-15 \\
\hline 87,2 & 72,3 & $\mathrm{P}$ & 14,6 & Aberta & PMR-15 \\
\hline 183 & 30,2 & $\mathrm{P}$ & 14,5 & Aberta & PMR-15 \\
\hline 94,5 & 34,6 & $\mathrm{P}$ & 14,3 & Aberta & PMR-15 \\
\hline \multicolumn{5}{|l|}{} \\
\hline
\end{tabular}




\section{Anexo III - Ensaios Hidráulicos}


Universidade de São Paulo

Instituto de Geociências

Dissertação de Mestrado

Project: Anexo III - Bail Testes

Evaluated by: Fernando Alves

Slug Test No. 1

Test conducted on: 02/2005

PMR-01B

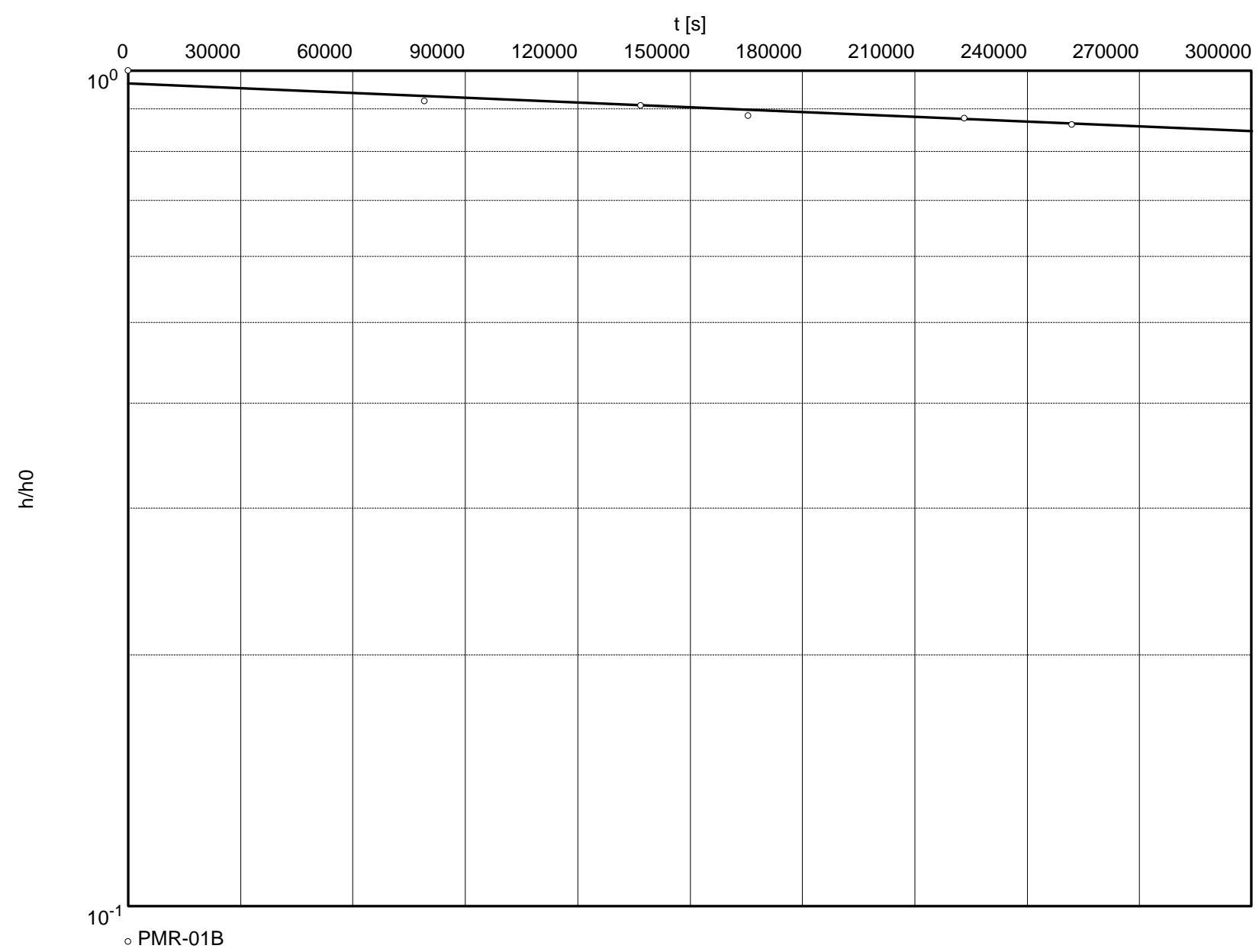

Hydraulic conductivity [cm/s]: $1.60 \times 18$ 
Universidade de São Paulo

Instituto de Geociências

Dissertação de Mestrado

\section{Slug Test No. 1}

PMR-01B

Static water level: $38.1 \mathrm{~cm}$ below datum

Pumping test duration

[s]

\begin{tabular}{l|}
1 \\
2 \\
\hline 3 \\
\hline 4 \\
\hline 5 \\
\hline 6
\end{tabular}

1

\begin{tabular}{r|r|r|}
\hline \multicolumn{2}{|c|}{ Water level } & \multicolumn{2}{|c|}{$\begin{array}{c}\text { Change in } \\
\text { Waterlevel } \\
{[\mathrm{cm}]}\end{array}$} \\
\hline 0 & {$[\mathrm{~cm}] \quad 4800.0$} & 4761.9 \\
\hline 79200 & 4418.0 & 4379.9 \\
\hline 136800 & 4360.0 & 4321.9 \\
\hline 165600 & 4246.0 & 4207.9 \\
\hline 223200 & 4211.0 & 4172.9 \\
\hline 252000 & 4140.0 & 4101.9 \\
\hline
\end{tabular}

g/bail test analysis

HVORSLEV's method

Date: 02/2008

Page 2

Project: Anexo III - Bail Testes

Evaluated by: Fernando Alves

Test conducted on: 02/2005

PMR-01B 
Universidade de São Paulo

Instituto de Geociências
Date: 02/2008

Page 1

Project: Anexo III - Bail Testes

Evaluated by: Fernando Alves

Slug Test No. 2

Test conducted on: 02/2005

PMR-02

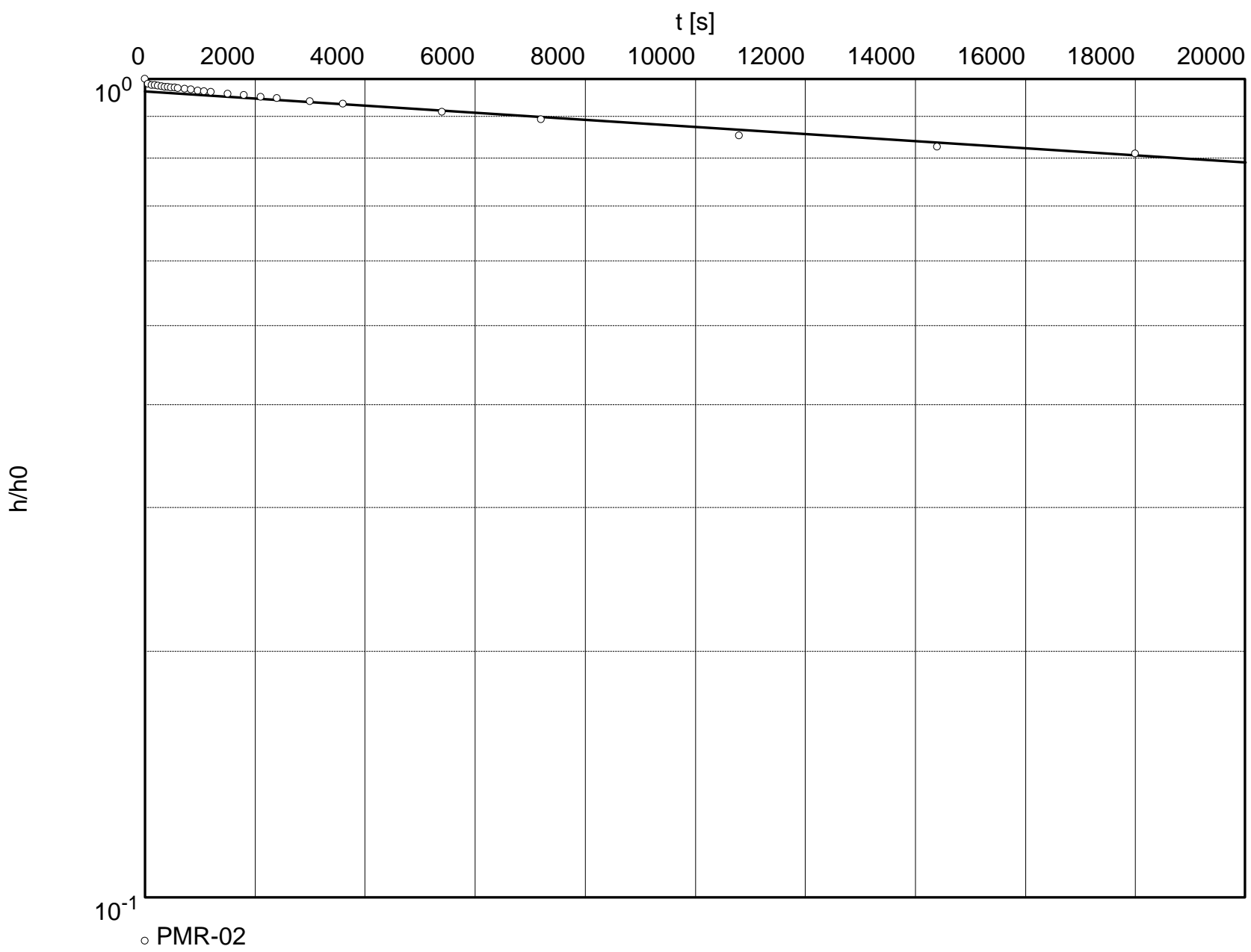

Hydraulic conductivity [cm/s]: $3,10 \times 10^{-7}$ 
Universidade de São Paulo

Instituto de Geociências \begin{tabular}{l|l} 
Date: $02 / 2008$ & Page 2
\end{tabular}

Project: Anexo III - Bail Testes

Evaluated by: Fernando Alves
Slug Test No. 2

PMR-02
Test conducted on: 02/2005

PMR-02

Static water level: $2670,0 \mathrm{~cm}$ below datum

Pumping test duration

[S]

\begin{tabular}{r|}
\hline 1 \\
\hline 2 \\
\hline 4 \\
\hline 5 \\
\hline 6 \\
\hline 7 \\
\hline 8 \\
\hline 9 \\
\hline 10 \\
\hline 11 \\
\hline 12 \\
\hline 13 \\
\hline 14 \\
\hline 15 \\
\hline 16 \\
\hline 17 \\
\hline 18 \\
\hline 19 \\
\hline 20 \\
\hline 21 \\
\hline 22 \\
\hline 23 \\
\hline 24 \\
\hline 25 \\
\hline 26 \\
\hline 27 \\
\hline
\end{tabular}
Water level

[cm]

3720,0

3704,5

3702,5

3701,3

3699,5

3698,0

3697,0

3695,8

3694,9

3693,9

3692,5

3690,5

3688,5

3686,0

3684,0

3682,0

3677,0

3673,0

3668,3

3664,5

3656,5

3648,5

3627,5

3607,5

3566,0

3537,3

3521,0
Change in

Waterlevel

[cm]

1050,0

1034,5

1032,5

1031,3

1029,5

1028,0

1027,0

1025,8

1024,9

1023,9

1022,5

1020,5

1018,5

1016,0

1014,0

1012,0

1007,0

1003,0

998,3

994,5

986,5

978,5

957,5

937,5

896,0

867,3

851,0 
Universidade de São Paulo

Instituto de Geociências

Dissertação de Mestrado

PMR-03

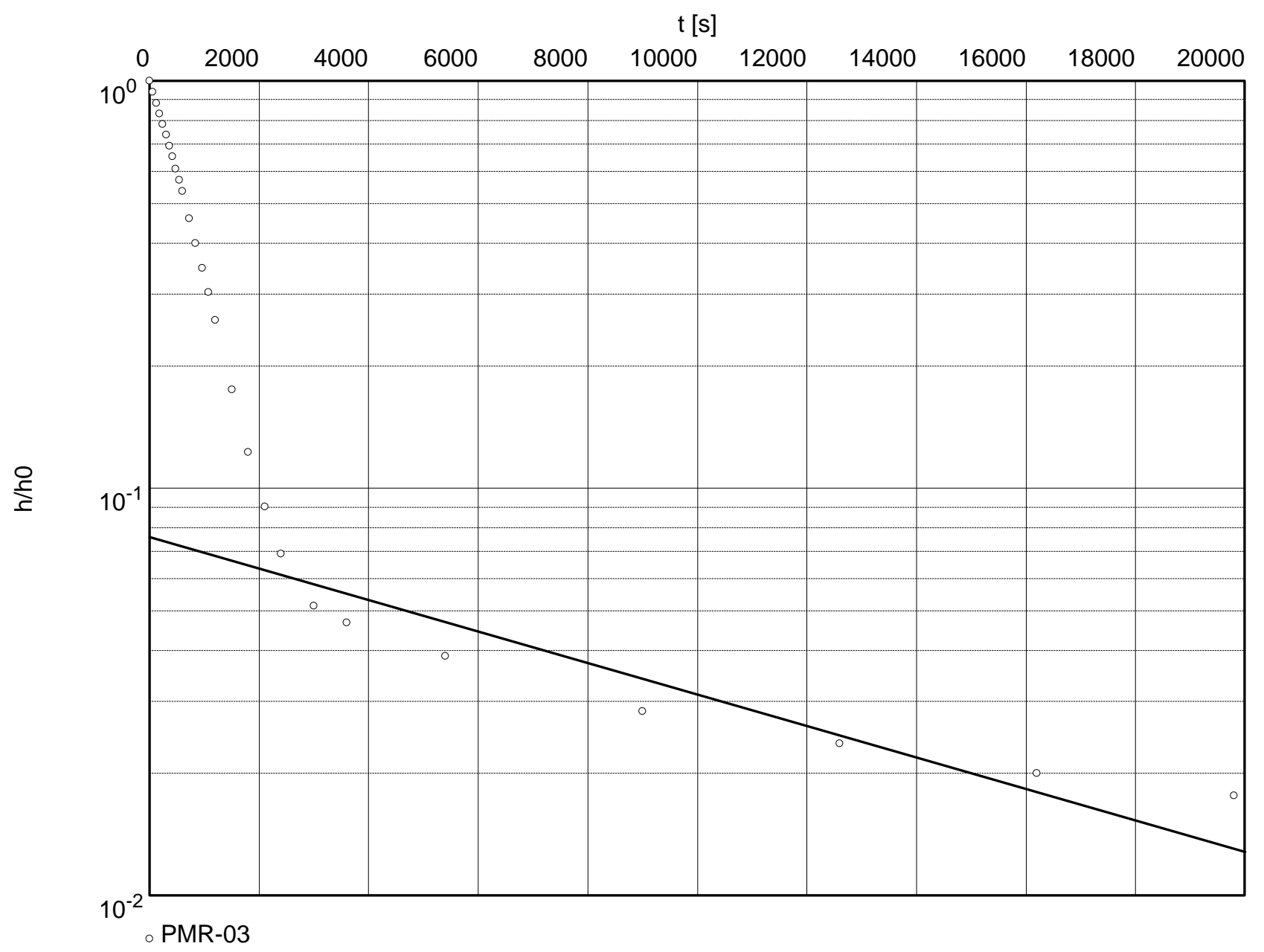

Hydraulic conductivity [cm/s]: $3,00 \times 10^{-6}$ 
Universidade de São Paulo

Instituto de Geociências \begin{tabular}{l|l} 
Date: $02 / 2008$ & Page 2
\end{tabular}

Project: Anexo III - Bail Test

Evaluated by: Fernando Alves

\section{Slug Test No. 3}

PMR-03

Static water level: $2538,8 \mathrm{~cm}$ below datum

Pumping test duration

[S]

$\begin{array}{r}1 \\ \hline 2 \\ 3 \\ \hline 4 \\ 5 \\ 6 \\ 7 \\ \hline 8 \\ \hline 9 \\ \hline 10 \\ \hline 11 \\ \hline 12 \\ \hline 13 \\ \hline 14 \\ \hline 15 \\ \hline 16 \\ \hline 17 \\ \hline 18 \\ \hline 19 \\ \hline 20 \\ \hline 21 \\ \hline 22 \\ \hline 23 \\ \hline 24 \\ \hline 25 \\ \hline 26 \\ \hline 27 \\ \hline\end{array}$
Water level

[cm]

3900,0

3815,0

3740,0

3670,0

3605,0

3542,0

3481,5

3425,5

3366,5

3317,0

3267,5

3163,5

3082,0

3012,0

2951,0

2891,0

2777,0

2706,0

2661,5

2633,0

2609,0

2602,5

2591,5

2577,5

2571,0

2566,0

2562,8
Test conducted on: 02/2005

PMR-03 
Universidade de São Paulo

Instituto de Geociências

Dissertação de Mestrado

Slug Test No. 4

PMR-04

Static water level: $2100.0 \mathrm{~cm}$ below datum

Pumping test duration

1

2

3

4

5

6

7

8

9

10

11

12

13

14

15

16

17

18

19

20

21 $[\mathrm{s}]$

s]

\begin{tabular}{|r|r}
\hline 0 \\
\hline 30 \\
\hline 90 \\
\hline 120 \\
\hline 150 \\
\hline 180 \\
\hline 240 \\
\hline 300 \\
\hline 420 \\
\hline 540 \\
\hline 720 \\
\hline 1020 \\
\hline 1320 \\
\hline 1620 \\
\hline 2220 \\
\hline 3420 \\
\hline 4020 \\
\hline 7020 \\
\hline 9420 \\
\hline 13020 \\
\hline
\end{tabular}

HVORSLEV's method

Date: 02/2008

Page 2

Project: Anexo III - Bail Testes

Evaluated by: Fernando Alves

Test conducted on: 02/2005

PMR-04
Water level

[cm]

\begin{tabular}{|l|}
\hline \\
\hline 4027.0 \\
\hline 4020.0 \\
\hline 3980.0 \\
\hline 3958.0 \\
\hline 3934.0 \\
\hline 3908.0 \\
\hline 3886.0 \\
\hline 3844.0 \\
\hline 3903.0 \\
\hline 3726.0 \\
\hline 3643.0 \\
\hline 3542.0 \\
\hline 3487.0 \\
\hline 3449.0 \\
\hline 3440.0 \\
\hline 3424.0 \\
\hline 3329.0 \\
\hline 3295.0 \\
\hline 3142.0 \\
\hline 3039.0 \\
\hline 2905.0 \\
\hline
\end{tabular}

Change in

Waterlevel

$[\mathrm{cm}]$

1927.0

1920.0

1880.0

1858.0

1834.0

1808.0

1786.0

1744.0

1803.0

1626.0

1543.0

1442.0

1387.0

1349.0

1340.0

1324.0

1229.0

1195.0

1042.0

939.0

805.0 
Universidade de São Paulo

Instituto de Geociências

Dissertação de Mestrado

PMR-05

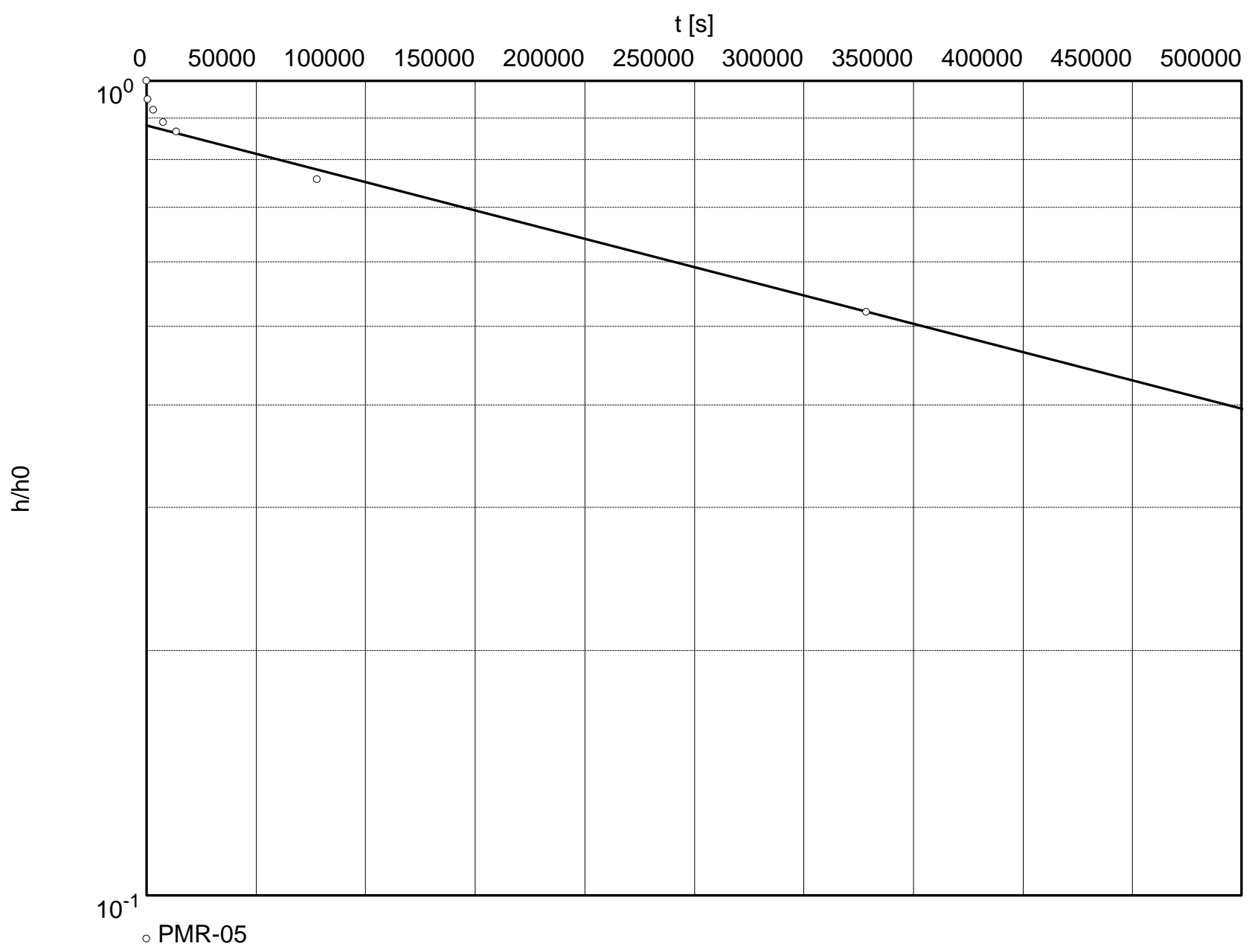

Hydraulic conductivity [cm/s]: $5,40 \times 10^{-8}$ 
Universidade de São Paulo

Instituto de Geociências
Date: 02/2008

Page 2

Project: Anexo III - Bail testes

Evaluated by: Fernando Alves

\section{Slug Test No. 5}

PMR-05

Static water level: $3135,5 \mathrm{~cm}$ below datum

\begin{tabular}{|c|c|c|c|}
\hline & $\begin{array}{l}\text { Pumping test duration } \\
\qquad[\mathrm{s}]\end{array}$ & $\begin{array}{l}\text { Water level } \\
\text { [cm] }\end{array}$ & $\begin{array}{l}\text { Change in } \\
\text { Waterlevel } \\
\text { [cm] }\end{array}$ \\
\hline 1 & 0 & 4200,0 & 1064,5 \\
\hline 2 & 600 & 4145,0 & 1009,5 \\
\hline 3 & 3000 & 4115,3 & 979,8 \\
\hline 4 & 7500 & 4082,5 & 947,0 \\
\hline 5 & 13500 & 4057,7 & 922,2 \\
\hline 6 & 77700 & 3942,0 & 806,5 \\
\hline 7 & 328500 & 3689,8 & 554,3 \\
\hline
\end{tabular}

Test conducted on: 02/2005

PMR-05 
Universidade de São Paulo

Instituto de Geociências

Dissertação de Mestrado

PMR-06

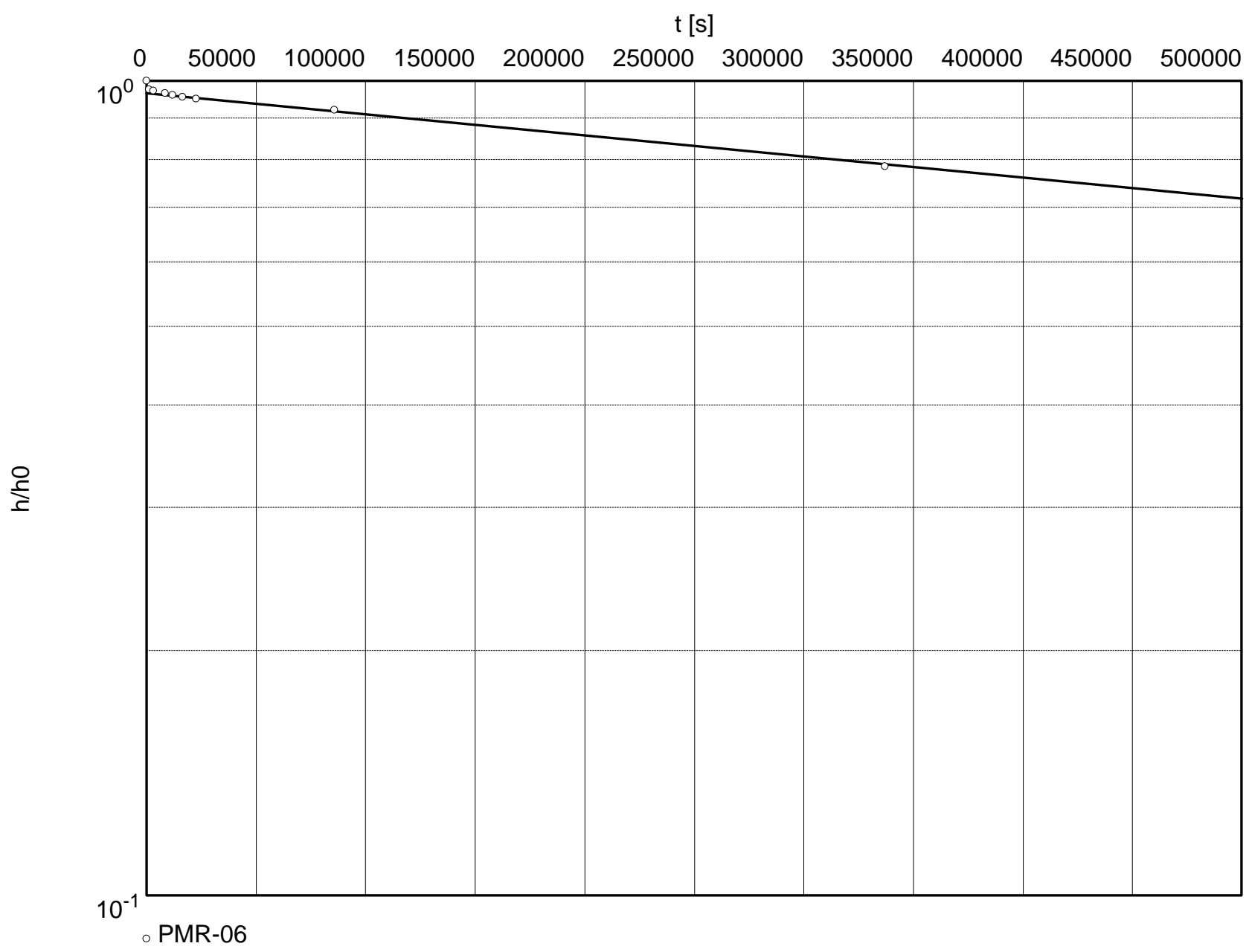

Hydraulic conductivity [cm/s]: 2,01 x 10-8 
Universidade de São Paulo

Instituto de Geociências
Date: 02/2008

Page 2

Project: Anexo III - Bail Testes

Evaluated by: Fernando Alves

\section{Slug Test No. 6}

PMR-06

Static water level: $2852,0 \mathrm{~cm}$ below datum

\begin{tabular}{|c|c|c|c|}
\hline & $\begin{array}{l}\text { Pumping test duration } \\
\qquad[\mathrm{s}]\end{array}$ & $\begin{array}{c}\text { Water level } \\
\text { [cm] }\end{array}$ & $\begin{array}{l}\text { Change in } \\
\text { Waterlevel } \\
\text { [cm] }\end{array}$ \\
\hline 1 & 0 & 5600,0 & 2748,0 \\
\hline 2 & 1200 & 5534,0 & 2682,0 \\
\hline 3 & 3000 & 5524,0 & 2672,0 \\
\hline 4 & 8400 & 5505,5 & 2653,5 \\
\hline 5 & 12000 & 5493,6 & 2641,6 \\
\hline 6 & 16500 & 5479,5 & 2627,5 \\
\hline 7 & 22500 & 5462,0 & 2610,0 \\
\hline 8 & 85800 & 5381,6 & 2529,6 \\
\hline 9 & 336900 & 5009,0 & 2157,0 \\
\hline
\end{tabular}

Test conducted on: 02/2005

PMR-06 
Universidade de São Paulo

Instituto de Geociências

Dissertação de Mestrado

PMR-07

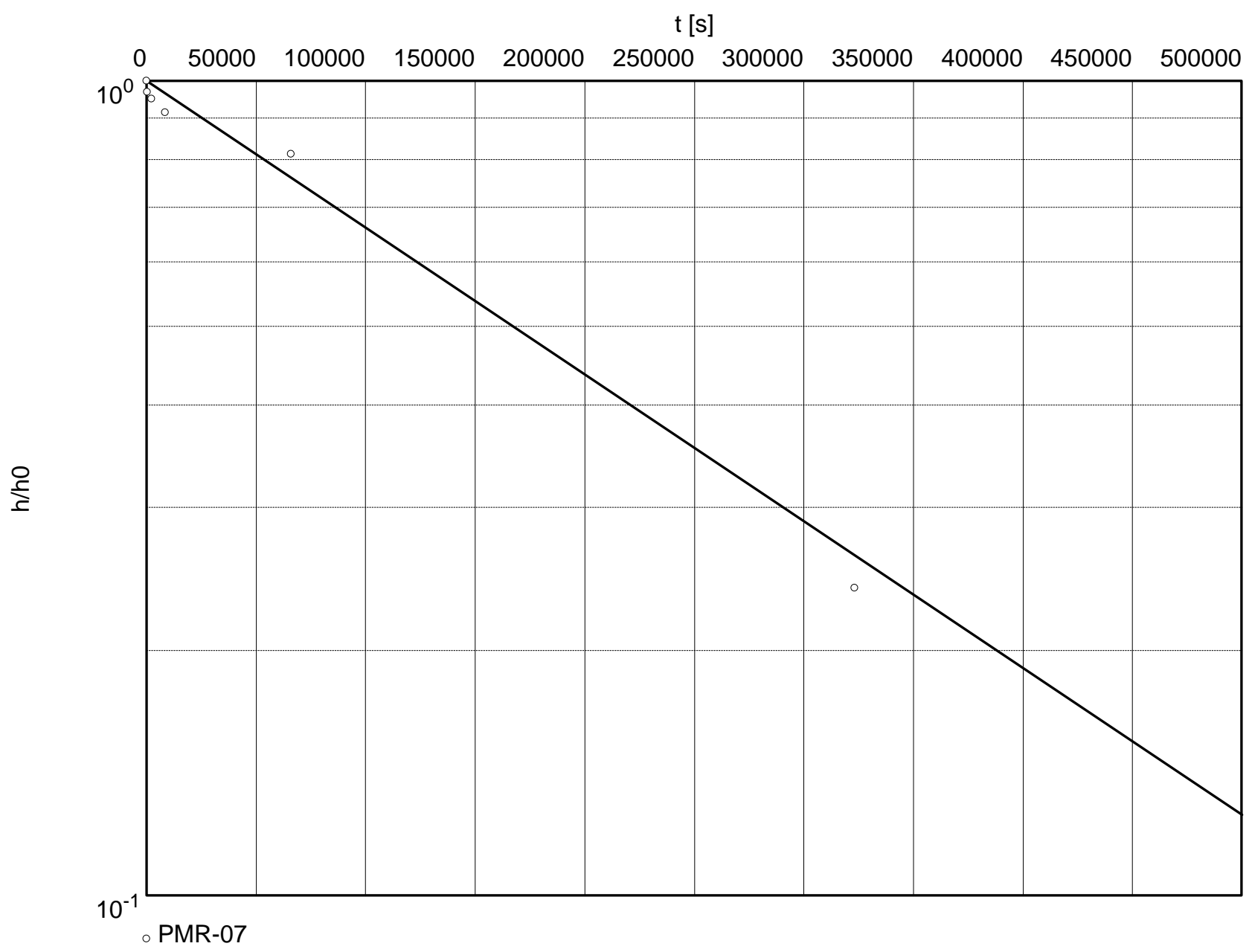

Hydraulic conductivity [cm/s]: 1,40 x 10-7 
Universidade de São Paulo

Instituto de Geociências
Date: 02/2008

Page 2

Project: Anexo III - Bail Testes

Evaluated by:
Slug Test No. 7

PMR-07
Test conducted on: 02/2005

PMR-07

Static water level: $2707,5 \mathrm{~cm}$ below datum

\begin{tabular}{|c|c|c|c|}
\hline & $\begin{array}{l}\text { Pumping test duration } \\
\qquad[\mathrm{s}]\end{array}$ & $\begin{array}{l}\text { Water level } \\
\text { [cm] }\end{array}$ & $\begin{array}{l}\text { Change in } \\
\text { Waterlevel } \\
\text { [cm] }\end{array}$ \\
\hline 1 & 0 & 4700,0 & 1992,5 \\
\hline 2 & 300 & 4638,0 & 1930,5 \\
\hline 3 & 2400 & 4601,0 & 1893,5 \\
\hline 4 & 8400 & 4529,3 & 1821,8 \\
\hline 5 & 66000 & 4328,6 & 1621,1 \\
\hline 6 & 323100 & 3183,5 & 476,0 \\
\hline
\end{tabular}




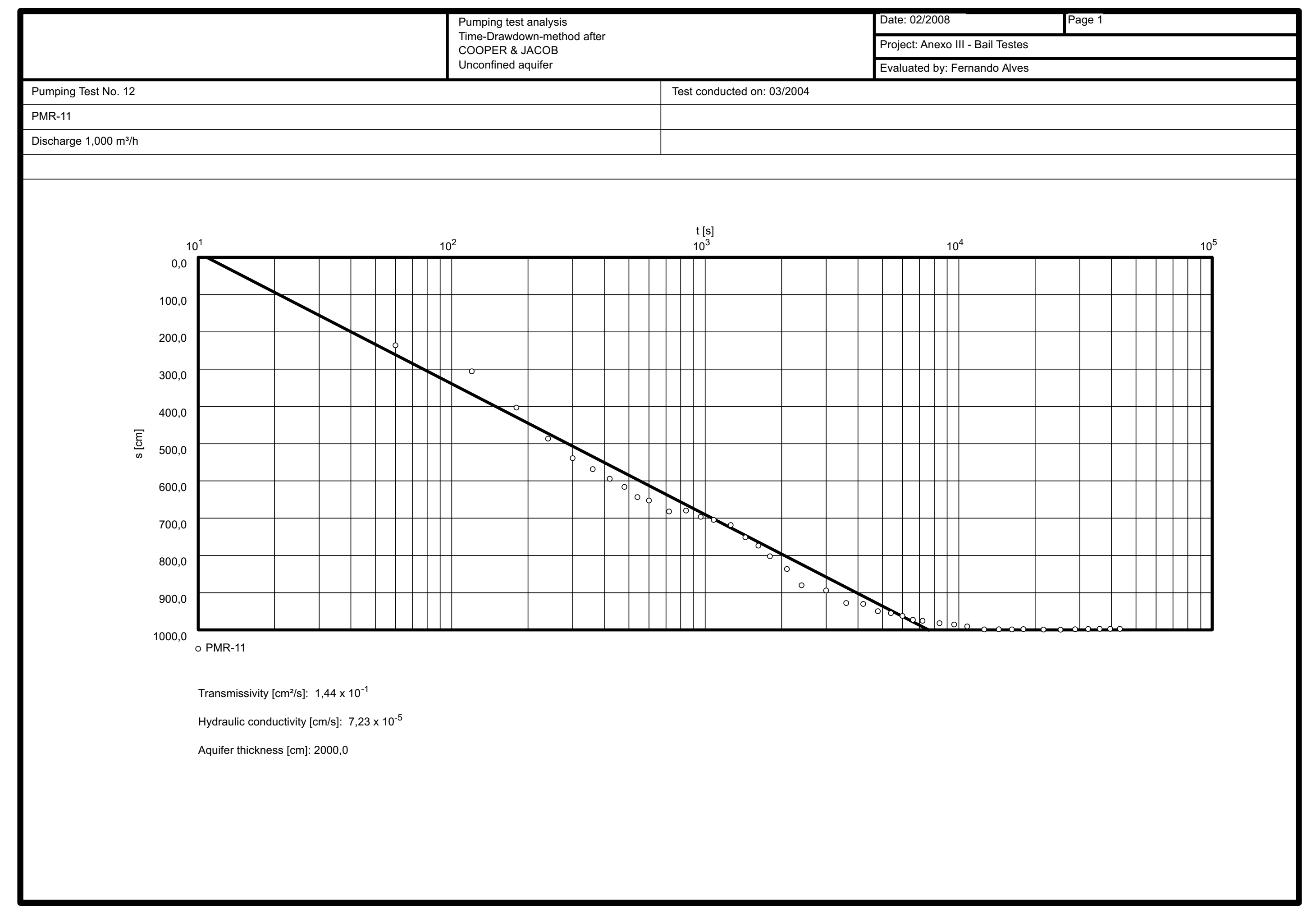




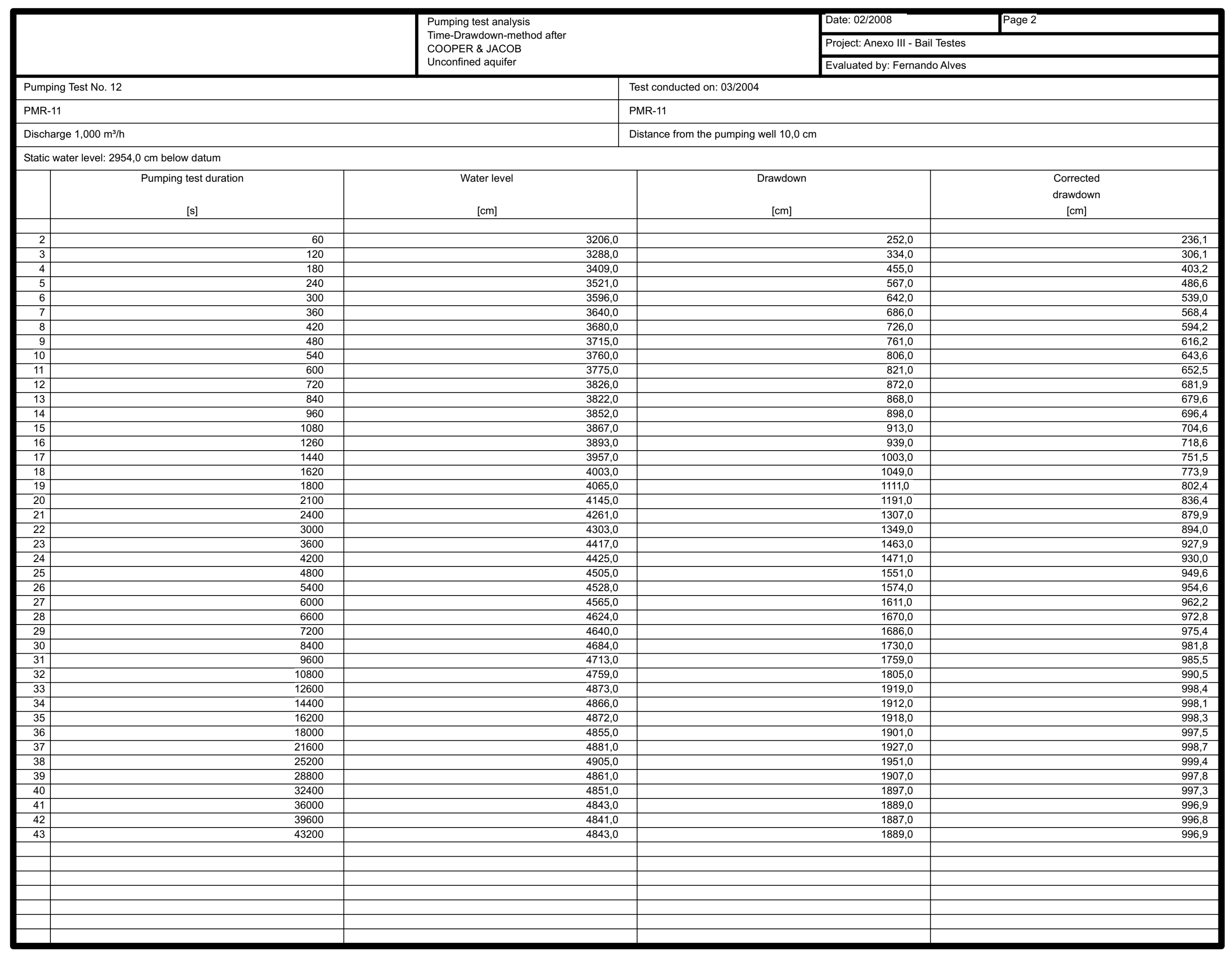


Universidade de São Paulo

Instituto de Geociências

Dissertação de Mestrado

PMR-12

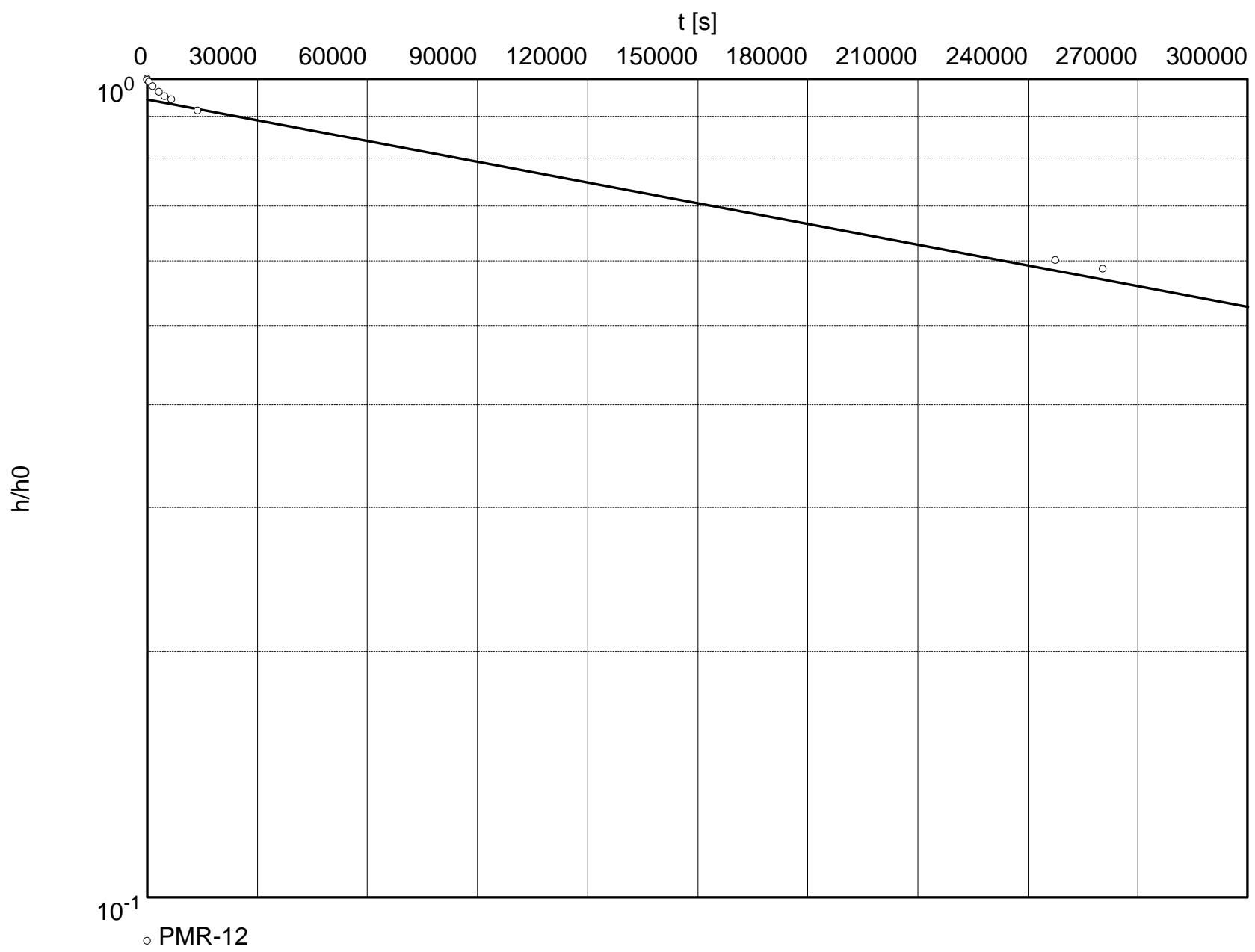

Hydraulic conductivity [cm/s]: $5,40 \times 10^{-8}$ 
Universidade de São Paulo

Instituto de Geociências \begin{tabular}{l|l} 
Date: $02 / 2008$ & Page 2
\end{tabular}

Project: Anexo III - Bail testes

Evaluated by: Fernando Alves
Slug Test No. 8

PMR-12

Static water level: $275,0 \mathrm{~cm}$ below datum

Pumping test duration

[s]

\begin{tabular}{r|r}
\hline 1 & 0 \\
\hline 2 & 60 \\
\hline 3 & 480 \\
4 & 1500 \\
5 & 3300 \\
6 & 4800 \\
7 & 6600 \\
\hline 8 & 13800 \\
\hline 10 & 247500 \\
\hline
\end{tabular}

Water level

[cm]

1960,0

1954,0

1944,0

1926,0

1898,0

1880,0

1865,0

1815,0

1286,5

1262,0
Test conducted on: $08 / 2005$

PMR-12
Change in

Waterlevel

[cm]

1685,0

1679,0

1669,0

1651,0

1623,0

1605,0

1590,0

1540,0

1011,5

987,0 
Universidade de São Paulo

Instituto de Geociências \begin{tabular}{l|l} 
Date: $02 / 2008$ & Page 1
\end{tabular}

Project: Anexo III - Bail Testes

Evaluated by: Fernando Alves

Slug Test No. 9

Test conducted on: 08/2005

PMR-13

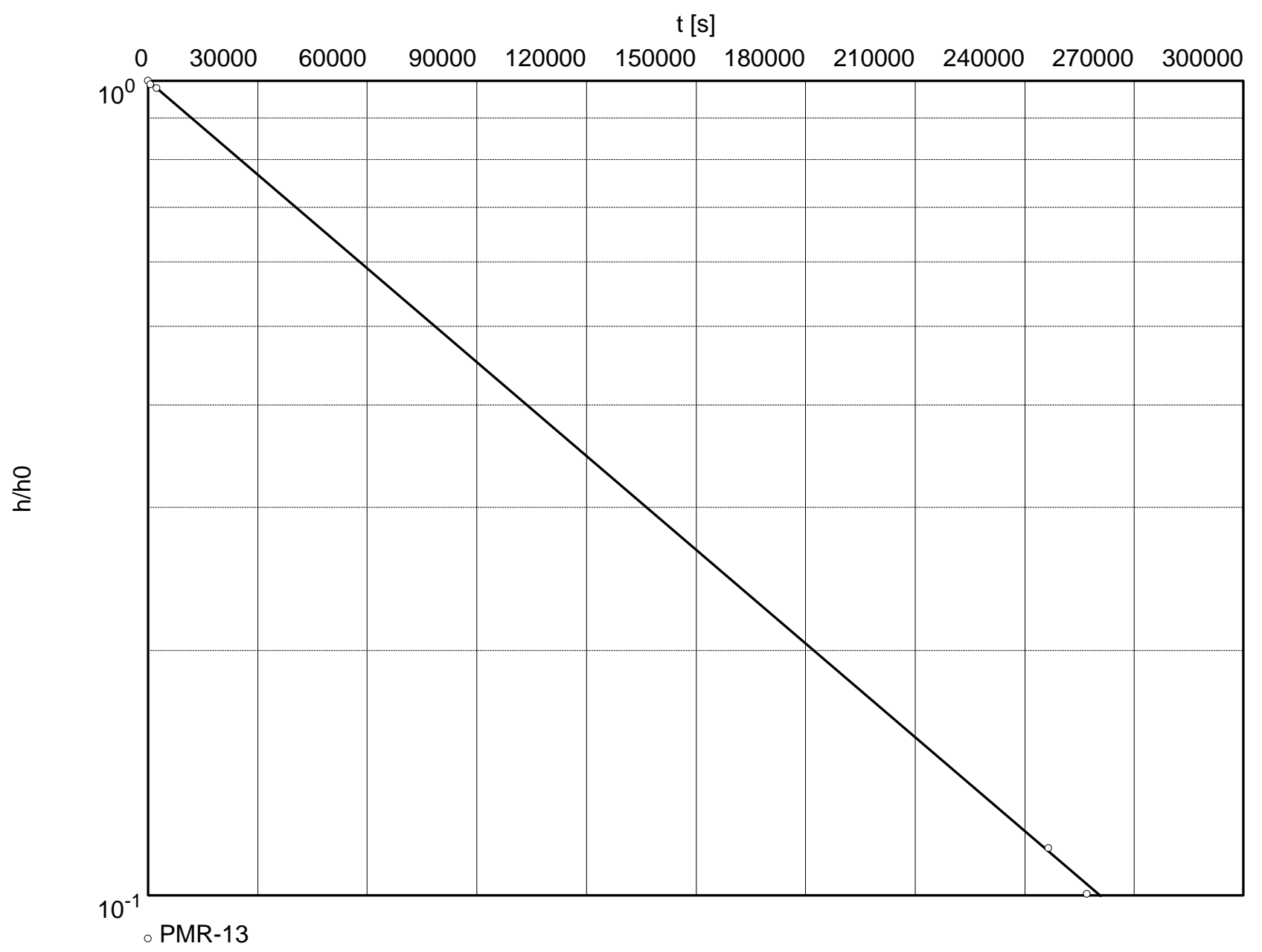

Hydraulic conductivity [cm/s]: 2,45 x 10-7 
Universidade de São Paulo

Instituto de Geociências
Date: 02/2008

Page 2

Project: Anexo III - Bail Testes

Evaluated by: Fernando Alves
Slug Test No. 9

PMR-13

Static water level: 502,0 cm below datum

\begin{tabular}{|c|c|c|c|}
\hline & $\begin{array}{l}\text { Pumping test duration } \\
\qquad[\mathrm{s}]\end{array}$ & $\begin{array}{c}\text { Water level } \\
\text { [cm] }\end{array}$ & $\begin{array}{l}\text { Change in } \\
\text { Waterlevel } \\
\text { [cm] }\end{array}$ \\
\hline 1 & 0 & 3200,0 & 2698,0 \\
\hline 2 & 600 & 3170,0 & 2668,0 \\
\hline 3 & 2400 & 3144,5 & 2642,5 \\
\hline 4 & 246600 & 811,0 & 309,0 \\
\hline 5 & 257100 & 773,0 & 271,0 \\
\hline
\end{tabular}

\section{PMR-13}


Universidade de São Paulo

Instituto de Geociências \begin{tabular}{|l|l} 
Date: $02 / 2008$ & Page 1
\end{tabular}

Project: Anexo III - Bail Testes

Evaluated by: Fernando Alves

Slug Test No. 9

Test conducted on: 08/2005

PMR-14 A

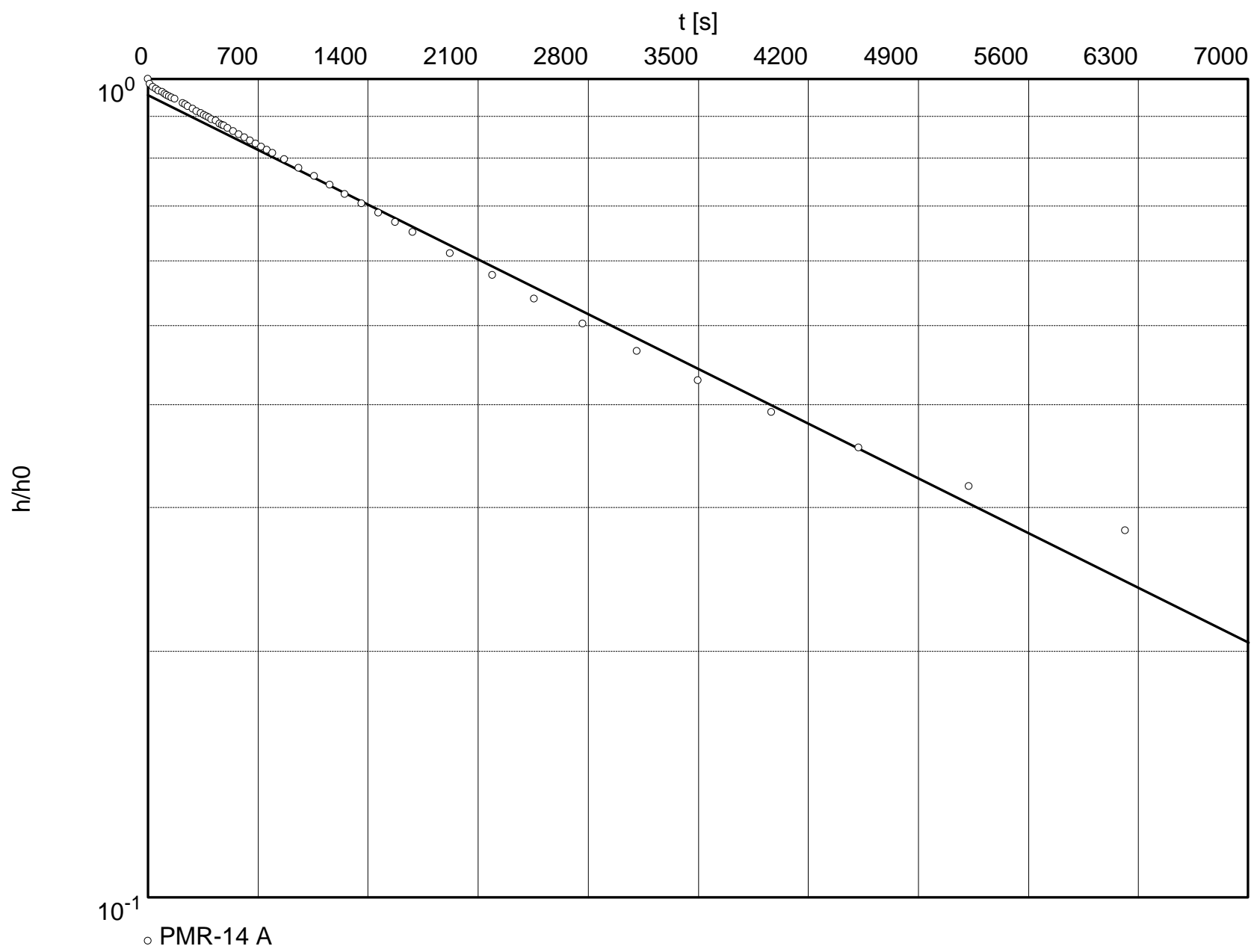

Hydraulic conductivity [cm/s]: 9,00 x 10-6 
Universidade de São Paulo

Instituto de Geociências

Dissertação de Mestrado slug/bail test analysis

HVORSLEV's method \begin{tabular}{l|l} 
Date: $02 / 2008$ & Page 2
\end{tabular}

Project: Anexo III - Bail Testes

Evaluated by: Fernando Alves
Slug Test No. 9

PMR-14 A
Test conducted on: 08/2005

PMR-14 A

Static water level: $237,7 \mathrm{~cm}$ below datum

Pumping test duration

[s]

1

3

4

5

6

7

8

9

10

11

12

13

14

15

16

17

18

19

20

21

22

23

24

25

26

27

28

29

30

31

32

33

34

35

36

37

38

39

40

41

42

43

44

45

46

47

48

49

50
Water level

[cm]

\begin{tabular}{|r|r}
\hline 0 & 2950,0 \\
10 & 2910,0 \\
\hline 30 & 2889,0 \\
\hline 50 & 2873,0 \\
\hline 66 & 2863,0 \\
\hline 90 & 2850,0 \\
\hline 107 & 2840,0 \\
\hline 120 & 2830,0 \\
\hline 135 & 2820,0
\end{tabular}

2810,0

2800,0

2770,0

2760,0

2748,0

2730,0

2715,0

2700,0

2690,0

2680,0

2670,0

2660,0

2650,0

2630,0

2620,0

2615,0

2600,0

2580,0

2560,0

2540,0

2520,0

2500,0

2480,0

2460,0

2440,0

2400,0

2350,0

2300,0

2250,0

2200,0

2150,0

2100,0

2050,0

2000,0

1900,0

1800,0

1700,0

1600,0

1500,0

1400,0

1300,0
Change in

Waterlevel

[cm]

2712,3

2672,3

2651,3

2635,3

2625,3

2612,3

2602,3

2592,3

2582,3

2572,3

2562,3

2532,3

2522,3

2510,3

2492,3

2477,3

2462,3

2452,3

2442,3

2432,3

2422,3

2412,3

2392,3

2382,3

2377,3

2362,3

2342,3

2322,3

2302,3

2282,3

2262,3

2242,3

2222,3

2202,3

2162,3

2112,3

2062,3

2012,3

1962,3

1912,3

1862,3

1812,3

1762,3

1662,3

1562,3

1462,3

1362,3

1262,3

1162,3

1062,3 
Universidade de São Paulo

Instituto de Geociências
Date: 02/2008

Page 3

Project: Anexo III - Bail Testes

Evaluated by: Fernando Alves
Slug Test No. 9

PMR-14 A
Test conducted on: 08/2005

PMR-14 A

Static water level: $237,7 \mathrm{~cm}$ below datum

\begin{tabular}{|c|c|c|c|}
\hline & $\begin{array}{l}\text { Pumping test duration } \\
\qquad[\mathrm{s}]\end{array}$ & $\begin{array}{l}\text { Water level } \\
\text { [cm] }\end{array}$ & $\begin{array}{l}\text { Change in } \\
\text { Waterlevel } \\
\text { [cm] }\end{array}$ \\
\hline 51 & 4521 & 1200,0 & 962,3 \\
\hline 52 & 5222 & 1100,0 & 862,3 \\
\hline 53 & 6217 & 1000,0 & 762,3 \\
\hline
\end{tabular}


Universidade de São Paulo

Instituto de Geociências
Date: 02/2008

Page 1

Project: Anexo III - Bail Testes

Evaluated by: Fernando Alves

Slug Test No. 10

Test conducted on: 08/2005

PMR-14 B

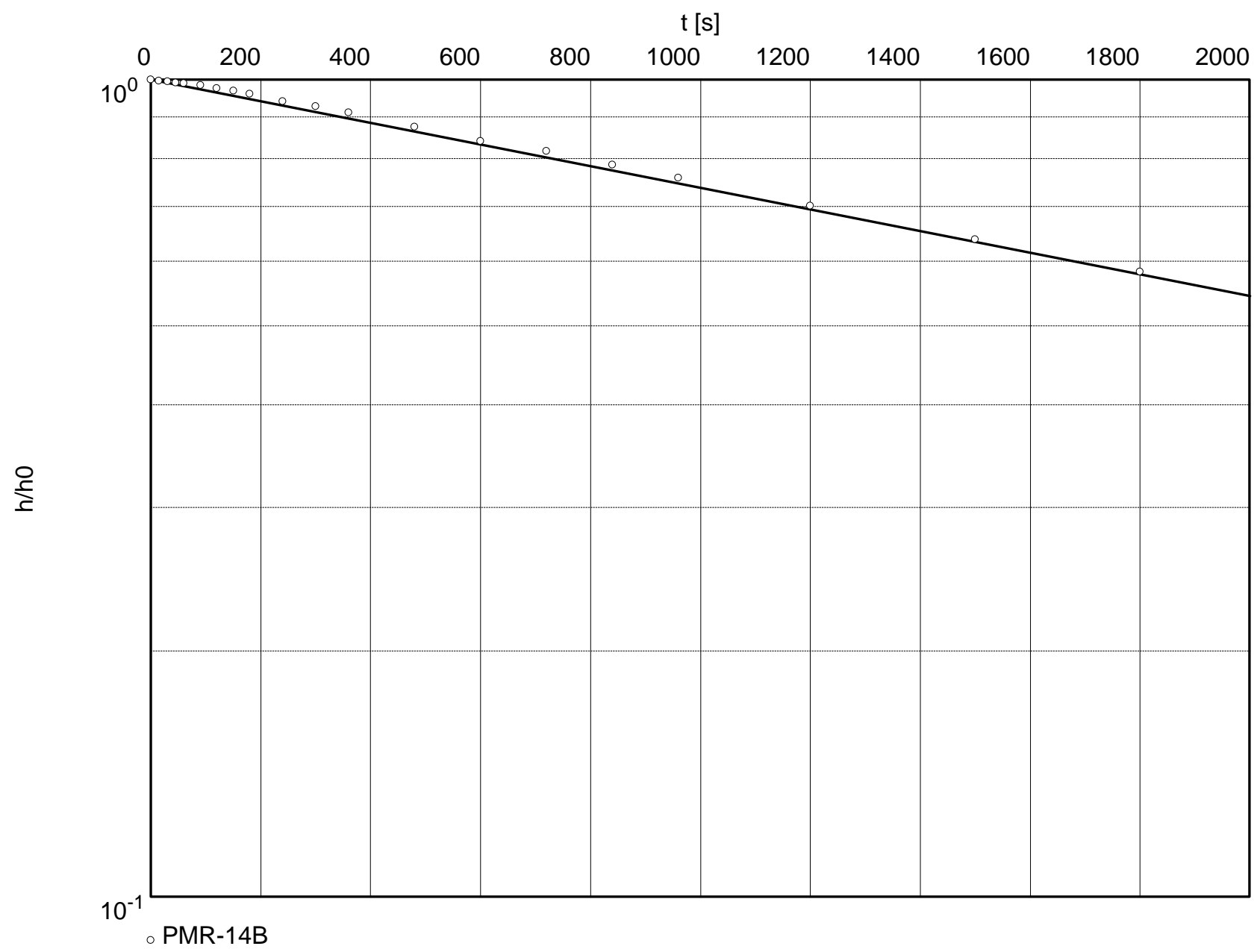

Hydraulic conductivity [cm/s]: 1,20 x 10-6 
Universidade de São Paulo

Instituto de Geociências \begin{tabular}{l|l} 
Date: $02 / 2008$ & Page 2
\end{tabular}

Project: Anexo III - Bail Testes

Evaluated by: Fernando Alves
Slug Test No. 10

PMR-14 B
Test conducted on: 08/2005

PMR-14B

Static water level: $236,0 \mathrm{~cm}$ below datum

\begin{tabular}{r|r|r|r} 
& Pumping test duration & Water level & \multicolumn{2}{c}{$\begin{array}{c}\text { Change in } \\
\text { Waterlevel } \\
\text { [cm] }\end{array}$} \\
\hline 1 & {$[\mathrm{~s}]$} & [cm] & 3664,0 \\
\hline 2 & 15 & 3900,0 & 3654,0 \\
\hline 3 & 30 & 3890,0 & 3644,0 \\
\hline 5 & 45 & 3880,0 & 3633,0 \\
\hline 6 & 60 & 3869,0 & 3623,0 \\
\hline 7 & 90 & 3859,0 & 3609,0 \\
\hline 8 & 120 & 3845,0 & 3574,0 \\
\hline 10 & 150 & 3810,0 & 3548,0 \\
\hline 11 & 180 & 3784,0 & 3517,0 \\
\hline 12 & 240 & 3753,0 & 3449,0 \\
\hline 13 & 300 & 3685,0 & 3396,0 \\
\hline 14 & 360 & 3632,0 & 3339,0 \\
\hline 15 & 480 & 3575,0 & 3209,0 \\
\hline 16 & 600 & 3445,0 & 3080,0 \\
\hline 17 & 720 & 3316,0 & 2994,0 \\
\hline 18 & 840 & 3230,0 & 2881,0 \\
\hline 19 & 960 & 3117,0 & 2779,0 \\
\hline 20 & 1200 & 3015,0 & 2569,0 \\
\hline & 1500 & 2805,0 & 2338,0 \\
\hline 1800 & 2574,0 & 2134,0 \\
\hline
\end{tabular}


Universidade de São Paulo

Instituto de Geociências \begin{tabular}{|l|l} 
Date: $02 / 2008$ & Page 1
\end{tabular}

Project: Anexo III - Bail Testes

Evaluated by: Fernando Alves

Slug Test No. 11

Test conducted on: 08/2005

PMR-15

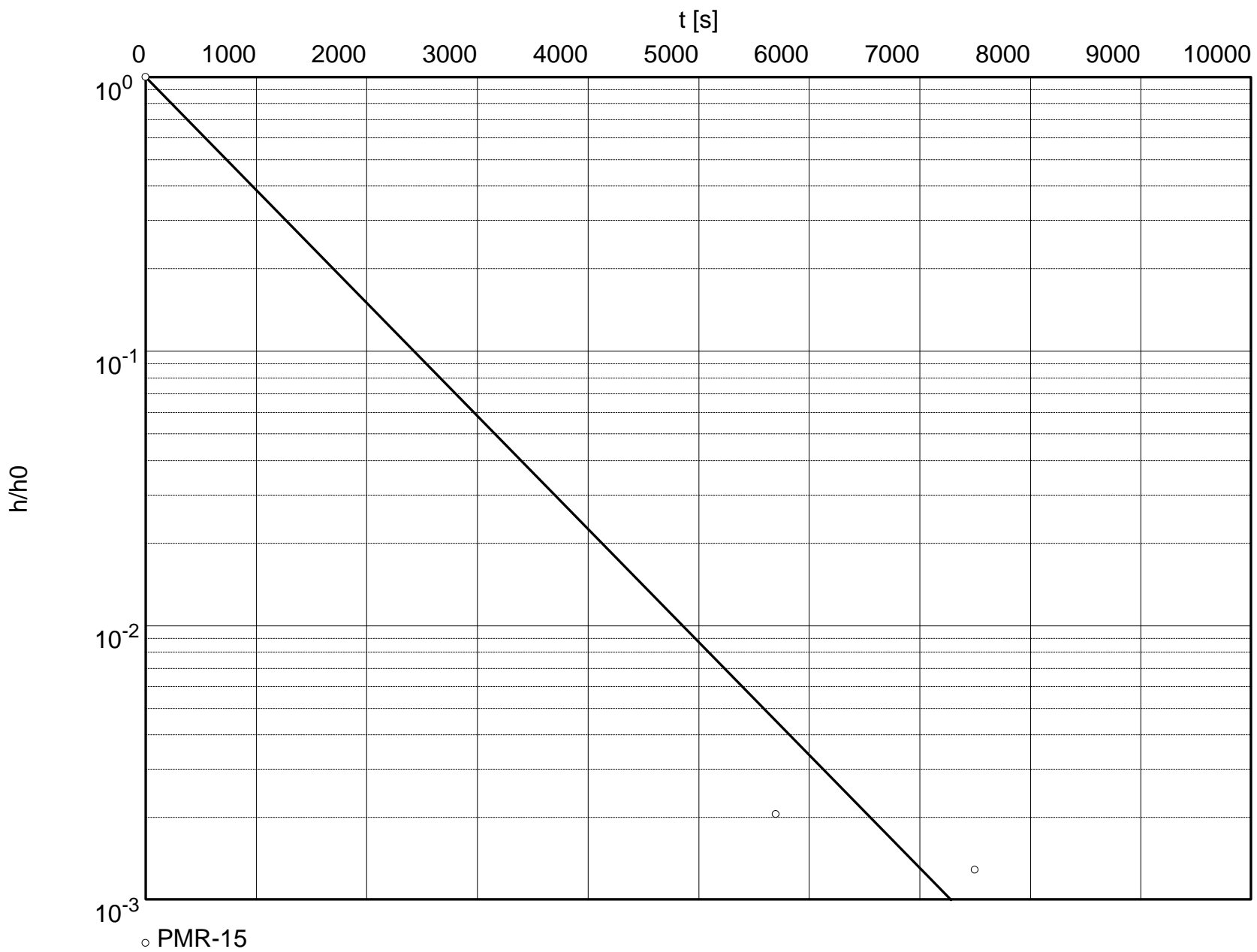

Hydraulic conductivity [cm/s]: $2,63 \times 10^{-5}$ 
Universidade de São Paulo

Instituto de Geociências
Date: 02/2008

Page 2

Project: Anexo III - Bail Testes

Evaluated by: Fernando Alves
Slug Test No. 11

PMR-15
Test conducted on: 08/2005

PMR-15

Static water level: $757,0 \mathrm{~cm}$ below datum

\begin{tabular}{|c|c|c|c|}
\hline & $\begin{array}{l}\text { Pumping test duration } \\
\qquad[\mathrm{s}]\end{array}$ & $\begin{array}{l}\text { Water level } \\
\text { [cm] }\end{array}$ & $\begin{array}{l}\text { Change in } \\
\text { Waterlevel } \\
\text { [cm] }\end{array}$ \\
\hline 1 & 0 & 2700,0 & 1943,0 \\
\hline 2 & 5700 & 761,0 & 4,0 \\
\hline 3 & 7500 & 759,5 & 2,5 \\
\hline
\end{tabular}




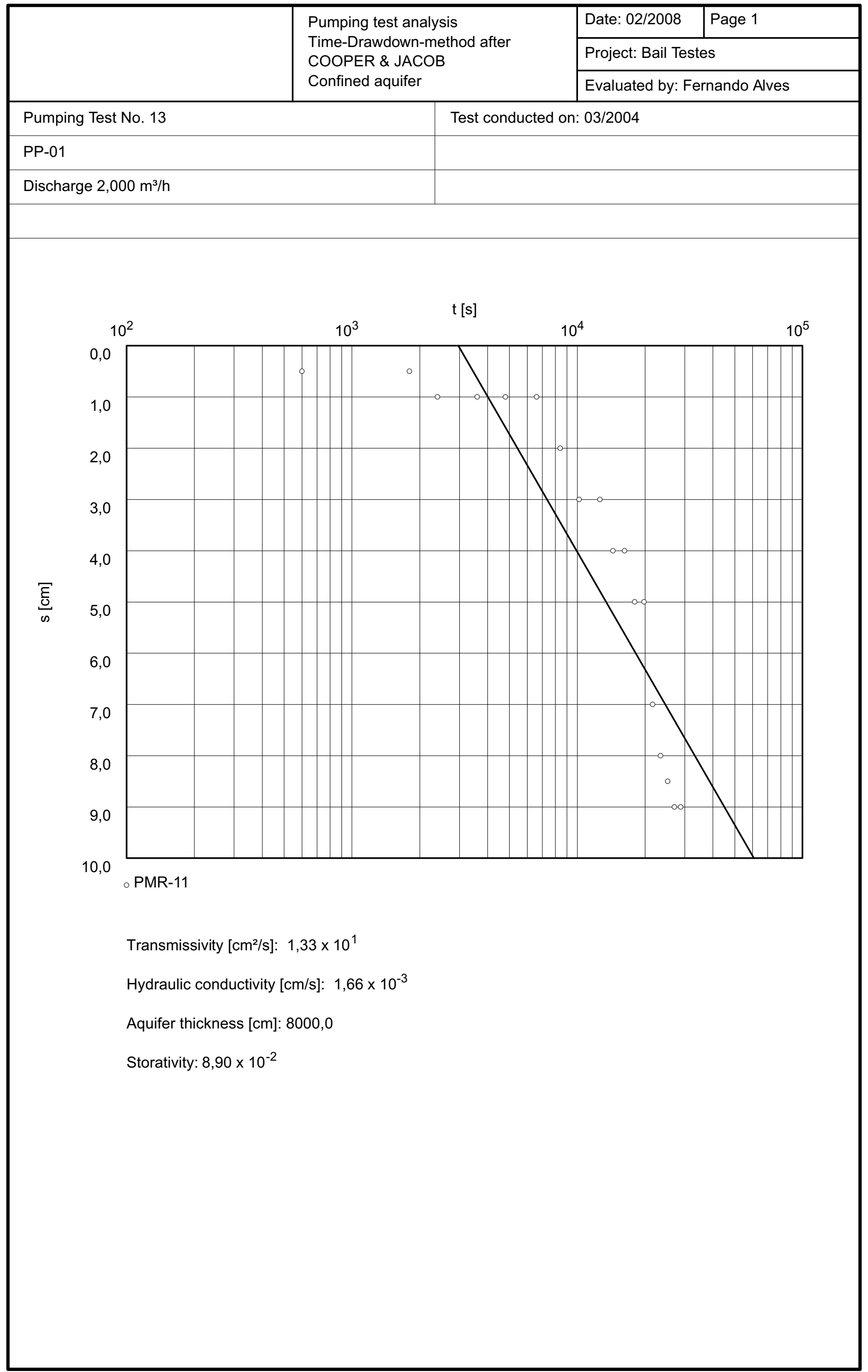


Pumping Test No. 13

PP-01

Discharge $2,000 \mathrm{~m}^{3} / \mathrm{h}$

Static water level: $2869,0 \mathrm{~cm}$ below datum

Pumping test duration

[s]

$\begin{array}{r} \\ \hline 600 \\ 1800 \\ \hline 2400 \\ \hline 3600 \\ 44800 \\ 6600 \\ \hline 8400 \\ \hline 10200 \\ \hline 12600 \\ \hline 14400 \\ \hline 16200 \\ \hline 18000 \\ \hline 19800 \\ \hline 21600 \\ \hline 23400 \\ \hline 25200 \\ \hline 27000 \\ \hline 28800\end{array}$

Water level

[cm]

2869,5

2869,5

2870,0

2870,0

2870,0

2870,0

2871,0

2872,0

2872,0

2873,0

2873,0

2874,0

2874,0

2876,0

2877,0

2877,5

2878,0

2878,0
Test conducted on: 03/2004

PMR-11

Distance from the pumping well $1000,0 \mathrm{~cm}$

\begin{tabular}{|rl}
\hline & \\
& \\
& \\
& \\
& \\
& 0,5 \\
& 0,5 \\
1,0 \\
1,0 \\
1,0 \\
1,0 \\
2,0 \\
3,0 \\
3,0 \\
4,0 \\
4,0 \\
5,0 \\
5,0 \\
7,0 \\
8,0 \\
8,5 \\
9,0 \\
9,0 \\
\hline
\end{tabular}

